\title{
Plant-availability of soil and fertilizer zinc in cultivated soils of Finland
}

\author{
MARKKU YLI-HALla
}

University of Helsinki

Department of Applied Chemistry and Microbiology FIN-00014 UNIVERSITY OF HELSINKI, Finland 



\section{PREFACE}

The experimental part of this study was mainly carried out at Kemira Oy Espoo Research Centre in 1987 - 1992, and the work was finalized in 1992 - 93 at the University of Helsinki, Section of Agricultural Chemistry and Physics of the Department of Applied Chemistry and Microbiology. I wish to thank Mr. Donald Jonasson, Vice president of R\&D, Dr. AinoMaija Evers, Dr. Simo Kivisaari and Mr. Jorma Syvälahti at Kemira Oy, for offering me the financial and institutional framework which facilitated this investigation. I also thank Dr. Antti Jaakkola, Professor of Agricultural Chemistry and Physics, for allowing me to join his section at the University to complete this study, and for his guidance and constructive criticism at the various stages of the work.

I am grateful to Dr. Helinä Hartikainen, Professor of Soil and Environmental Chemistry, and Docent Erkki Kemppainen for checking my work. My thanks are extended to the staff of the former Agricultural Department of Kemira Oy Espoo Research Centre both at Suomenoja and at the Kotkaniemi Experimental Farm for technical assistance in the experiments. My warmest thanks are due especially to Mrs. Saara Sinisalo whose expertise was indispensable in the laboratory and to Mr. Esko Viikari who skilfully took care of the field experiments. I also thank the district sales representatives of Kemira Oy who provided me with part of the soil samples used in this work. I would also like to thank the technicians of the Section of Agricultural Chemistry and Physics at the University for helping me complete the analytical work. The figures were drawn by Ms. Hillevi Tenninen and the English manuscript was revised by Mrs. Sevastiana Ruusamo, M.A. and edited by Mrs. Sari Torkko, M.Sc., to whom I express my appreciation for their work. This study was financially supported by the Scientific Foundation of the Finnish Association of Academic Agronomists (Agronomien Yhdistyksen tieteellinen säätiö), for which I express my sincere gratitude. Finally, I would like to thank the board of Agricultural Science in Finland for accepting this study to be published in their journal. 



\section{CONTENTS}

ABSTRACT . . . . . . . . 203

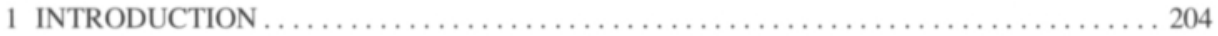

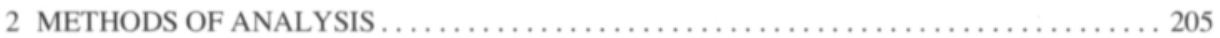

2.1 Testing the methods of soil $\mathrm{Zn}$ determination $\ldots \ldots \ldots \ldots \ldots \ldots \ldots \ldots \ldots \ldots \ldots \ldots \ldots \ldots \ldots$

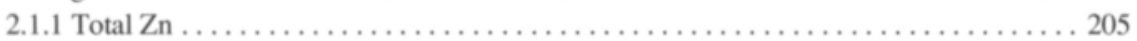

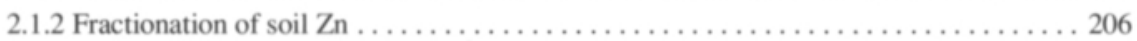

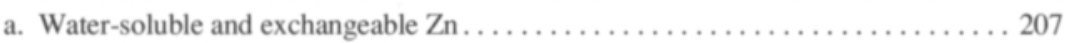

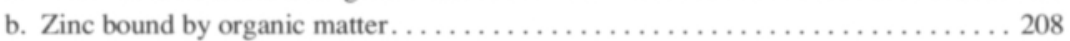

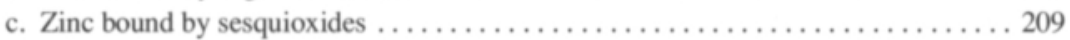

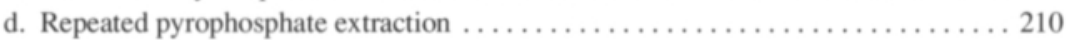

e. Reproducibility and additivity of the results of sequential extractions. . . . . . 210

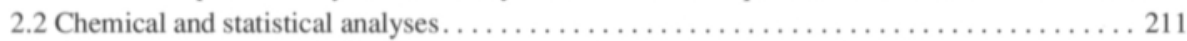

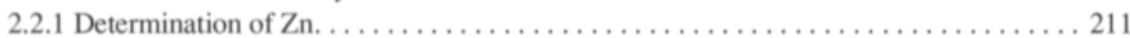

a. Total $\mathrm{Zn}$ and chemically specific fractions of $\mathrm{Zn}$ in soil $\ldots \ldots \ldots \ldots \ldots \ldots \ldots \ldots \ldots \ldots$

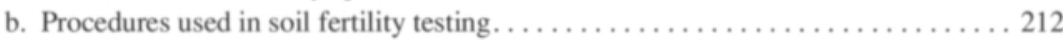

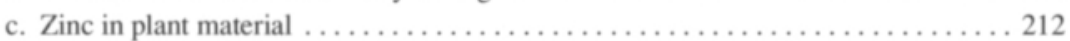

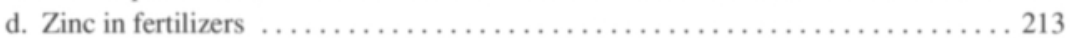

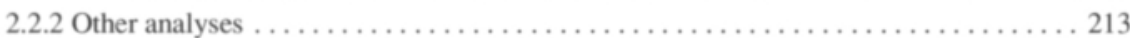

2.2 .3 Statistical methods $\ldots \ldots \ldots \ldots \ldots \ldots \ldots \ldots \ldots \ldots \ldots \ldots \ldots \ldots \ldots \ldots \ldots \ldots \ldots$

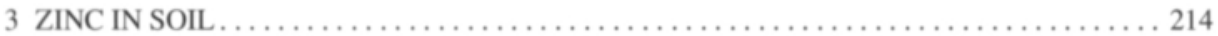

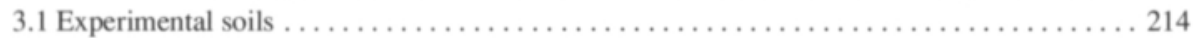

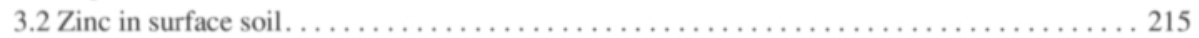

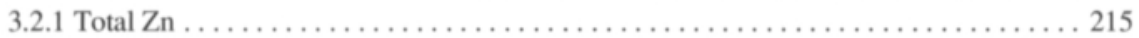

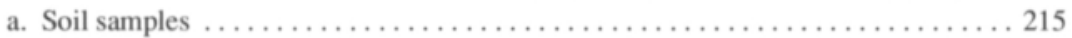

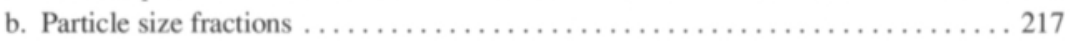

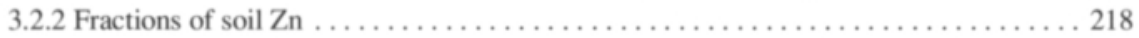

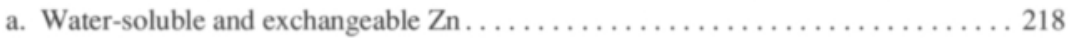

b. Zinc bound by organic matter and sesquioxides. . . . . . . . . . . . . . 218

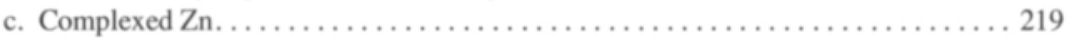

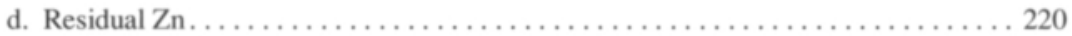

e. Relationship between $\mathrm{Zn}$ fractions and other soil properties $\ldots \ldots \ldots \ldots \ldots \ldots 220$

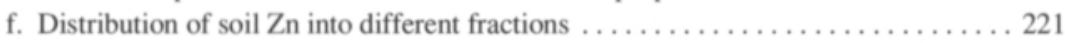

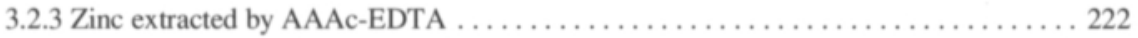

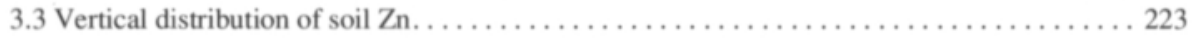

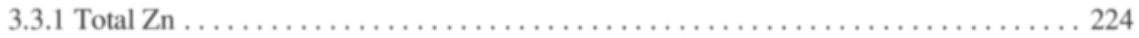

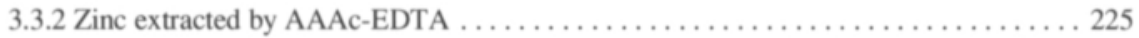

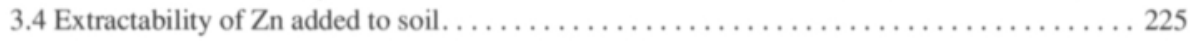

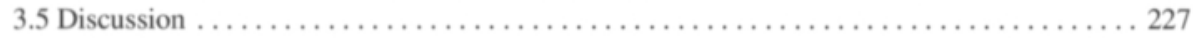

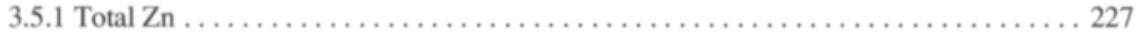

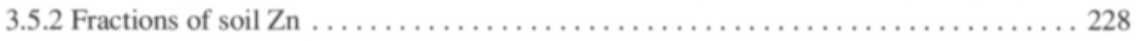

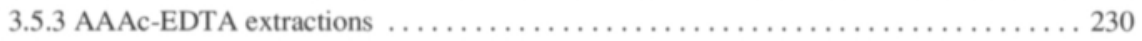

4 AVAILABILITY OF SOIL AND FERTILIZER ZINC TO RYEGRASS

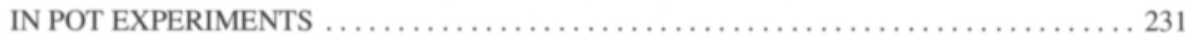

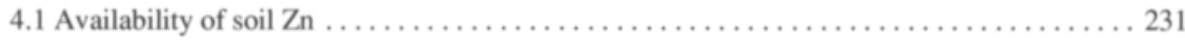

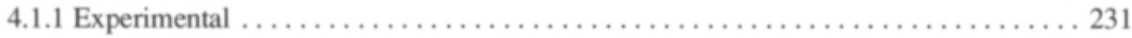

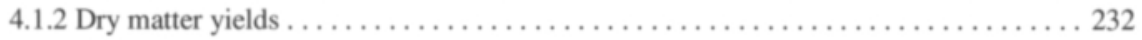

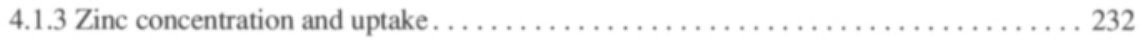

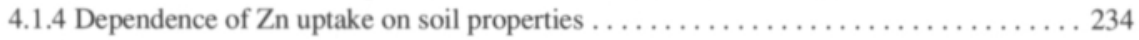

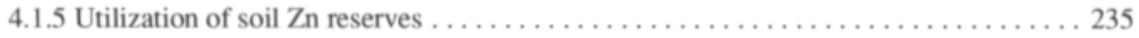




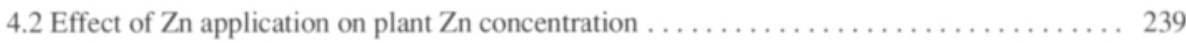

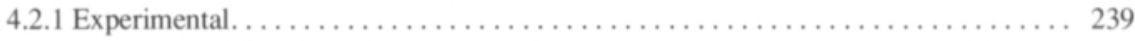

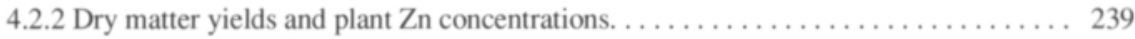

4.2.3 Influence of soil characteristics on the response to applied $\mathrm{Zn} \ldots \ldots \ldots \ldots \ldots \ldots 240$

4.2.4 Response of ryegrass to applied $\mathrm{Zn}$ in soils poor in $\mathrm{Zn}_{\mathrm{Ac}} \ldots \ldots \ldots \ldots \ldots \ldots \ldots \ldots 242$

4.3 Effect of liming and different rates of $\mathrm{Zn}$ application on ryegrass. . . . . . . . . . 243

4.3 .1 Experimental. . . . . . . . . . . . . 243

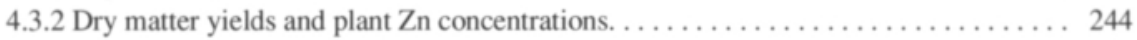

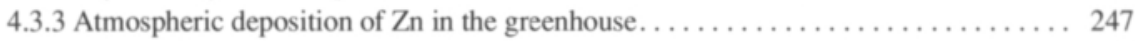

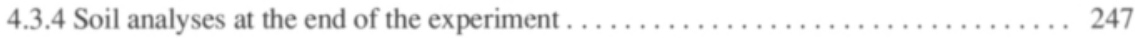

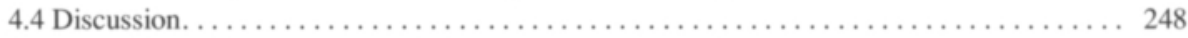

5 FERTILIZERS AS ZINC SOURCES IN POT AND FIELD EXPERIMENTS $\ldots \ldots \ldots \ldots \ldots 250$

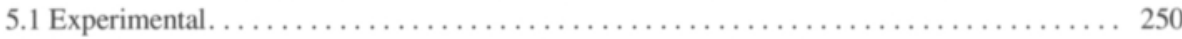

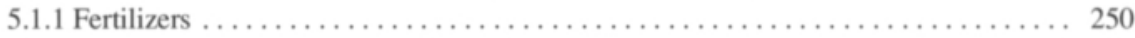

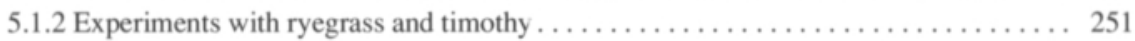

a. Comparison of $\mathrm{Zn}$ fertilizers in a pot experiment $\ldots \ldots \ldots \ldots \ldots \ldots \ldots \ldots \ldots \ldots \ldots \ldots \ldots \ldots \ldots \ldots \ldots$

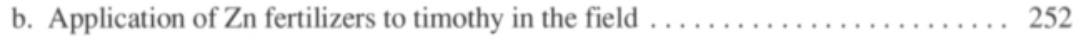

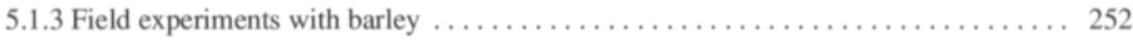

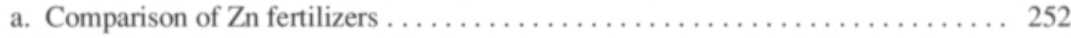

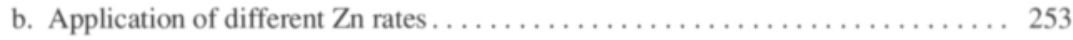

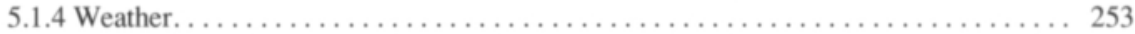

5.2 Comparison of $\mathrm{Zn}$ fertilizers, $\mathrm{Zn}$ rates and application practices with grass crops . . . . . 254

5.2 .1 Effect of $\mathrm{Zn}$ fertilizers on ryegrass in a pot experiment $\ldots \ldots \ldots \ldots \ldots \ldots \ldots \ldots 254$

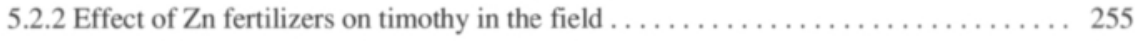

5.3 Comparison of $\mathrm{Zn}$ fertilizers, $\mathrm{Zn}$ rates and application practices with barley ........ 257

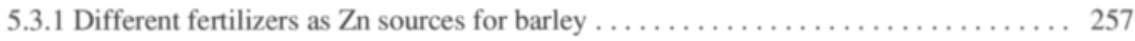

5.3.2 Plant $\mathrm{Zn}$ concentration as affected by different $\mathrm{Zn}$ rates $\ldots \ldots \ldots \ldots \ldots \ldots \ldots 258$

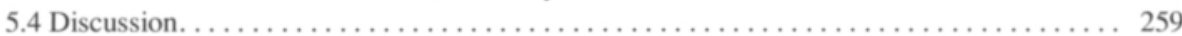

6 GENERAL DISCUSSION AND CONCLUSIONS $\ldots \ldots \ldots \ldots \ldots \ldots \ldots \ldots \ldots \ldots \ldots \ldots \ldots 26 \ldots \ldots$

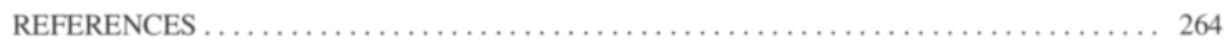

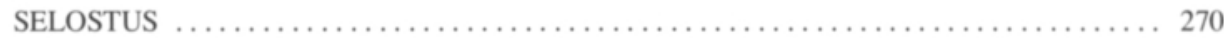

APPENDICES 1-9 


\title{
Plant-availability of soil and fertilizer zinc in cultivated soils of Finland
}

\author{
MARKKU YLI-HALLA
}

\begin{abstract}
YLI-HALLA, M. 1993. Plant-availability of soil and fertilizer zinc in cultivated soils of Finland. Agric. Sci. Finl. 2: 197-270. (Dept. Appl. Chem. Microbiol. FIN-00014 University of Helsinki, Finland.)
\end{abstract}

The $\mathrm{Zn}$ status of cultivated soils of Finland was investigated by chemical analyses and bioassays. The effect on ryegrass of different $\mathrm{Zn}$ fertilizers and $\mathrm{Zn}$ rates was studied in pot experiments and their effect on barley and timothy in field experiments. In an uncontaminated surface soil material of 72 mineral soils and 34 organogenic soils, total $\mathrm{Zn}\left(\mathrm{Zn}_{\text {tot }}\right)$ was 10.3 - $202 \mathrm{mg} \mathrm{kg}^{-1}$ (median $\left.66 \mathrm{mg} \mathrm{kg}^{-1}\right)$. In mineral soils, $\mathrm{Zn}_{\text {tot }}$ correlated positively with clay content $\left(r=0.81^{* * *}\right)$ and in organogenic soils negatively with organic $\mathrm{C}\left(\mathrm{r}=-0.53^{* * *}\right)$. Zinc bound by organic matter and sesquioxides was sequentially extracted by $0.1 \mathrm{M} \mathrm{K}_{4} \mathrm{P}_{2} \mathrm{O}_{7}\left(\mathrm{Zn}_{\text {py }}\right)$ and $0.05 \mathrm{M}$ oxalate at $\mathrm{pH} 2.9\left(\mathrm{Zn}_{\text {ox }}\right)$, respectively. The sum $\mathrm{Zn}_{\text {py }}+\mathrm{Zn}_{\text {ox }}$, a measure of secondary $\mathrm{Zn}$ potentially available to plants, was $2-88 \%$ of $\mathrm{Zn}_{\text {tot }}$ and was the lowest in clay (median $5 \%$ ) and highest in peat soils (median 49\%). Water-soluble and exchangeable $\mathrm{Zn}$ consisted of $0.3-37 \%$ (median $3 \%$ ) of $\mathrm{Zn}_{\text {tot }}$, the percentage being higher in acid soils, particularly in peat soils. Zinc was also extracted by $0.5 \mathrm{M}$ ammonium acetate - $0.5 \mathrm{M}$ acetic acid - $0.02 \mathrm{M} \mathrm{Na}$-EDTA at $\mathrm{pH} 4.65\left(\mathrm{Zn}_{\mathrm{Ac}}\right)$, the method used in soil testing in Finland. The quantities of $\mathrm{Zn}_{\mathrm{Ac}}$ (median $2.9 \mathrm{mg} \mathrm{dm}^{-3}$, range $0.6-29.9 \mathrm{mg} \mathrm{dm}^{-3}$ ) averaged $50 \%$ and $75 \%$ of $\mathrm{Zn}_{p y}+\mathrm{Zn}_{\mathrm{ox}}$ in mineral and organogenic soils, respectively, and correlated closely with $\mathrm{Zn}_{\text {py }}$. In soil profiles, $\mathrm{Zn}_{\mathrm{Ac}}$ was with few exceptions higher in the plough layer $(0-20 \mathrm{~cm})$ than in the subsoil $(30-100 \mathrm{~cm})$.

In an intensive pot experiment on 107 surface soils, four crops of ryegrass took up 2 $-68 \%$ (median $26 \%$ ) of $\mathrm{Zn}_{\text {py }}+\mathrm{Zn}_{\text {ox }}$. The plant-available $\mathrm{Zn}$ reserves were not exhausted even though in a few peat soils the $\mathrm{Zn}$ supply to grass decreased over time. Variation of $\mathrm{Zn}$ uptake was quite accurately explained by $\mathrm{Zn}_{\mathrm{Ac}}$ but increasing $\mathrm{pH}$ had a negative impact on $\mathrm{Zn}$ uptake. Application of $\mathrm{Zn}\left(10 \mathrm{mg} \mathrm{dm}^{-3}\right.$ of soil as $\left.\mathrm{ZnSO}_{4} \cdot 7 \mathrm{H}_{2} \mathrm{O}\right)$ did not give rise to yield increases. In mineral soils, increase of plant $\mathrm{Zn}$ concentration correlated negatively with soil $\mathrm{pH}$ while $\mathrm{Zn}_{\mathrm{Ac}}$ was of secondary importance. In those organogenic soils in which the reserves of native $\mathrm{Zn}$ were the most effectively utilized, plant $\mathrm{Zn}$ concentration also responded most strongly to applied $\mathrm{Zn}$.

In two 2-year field experiments, $\mathrm{Zn}$ application did not increase timothy or barley yields. Zinc concentration of timothy increased from $30 \mathrm{mg} \mathrm{kg}^{-1}$ to 33 and $36 \mathrm{mg} \mathrm{kg}^{-1}$ when 3 or $6 \mathrm{~kg} \mathrm{Zn} \mathrm{ha}^{-1}$ was applied, respectively. The efficiency of $\mathrm{ZnSO}_{4} \cdot 7 \mathrm{H}_{2} \mathrm{O}$ alone did not differ from that of a fertilizer where $\mathrm{ZnSO}_{4} \cdot 7 \mathrm{H}_{2} \mathrm{O}$ was granulated with gypsum. Zinc concentration of barley grains increased by foliar sprays of $\mathrm{Na}_{2} \mathrm{Zn}$-EDTA but only a marginal response to soil-applied $\mathrm{Zn}$ ( 4.8 or $5.4 \mathrm{~kg} \mathrm{ha}^{-1}$ over three years) was detected in three 3-year experiments. High applications of $\mathrm{Zn}$ to soil ( 15 or $30 \mathrm{~kg} \mathrm{ha}^{-1}$ as $\mathrm{ZnSO}_{4}$ - $7 \mathrm{H}_{2} \mathrm{O}$ ) were required to increase $\mathrm{Zn}$ concentration of barley markedly.

In order to prevent undue accumulation of fertilizer $\mathrm{Zn}$ in soil, it is proposed that $\mathrm{Zn}$ fertilizer recommendations for field crops should be based on both soil $\mathrm{pH}$ and $\mathrm{Zn}_{\mathrm{Ac}}$. In slightly acid and neutral soils, even if poor in $\mathrm{Zn}$, response of plant $\mathrm{Zn}$ concentration to applied $\mathrm{Zn}$ remains small while there is a high response in strongly acid soils.

Key words: soil analysis, vertical distribution of soil Zn, pot experiments, field experiments, liming, plant $\mathrm{Zn}$ concentration, barley, ryegrass, timothy 


\section{INTRODUCTION}

Zinc is a trace element, the average concentration of which in the earth's crust is quoted as $70 \mathrm{mg} \mathrm{kg}^{-1}$ (WEDEPOHL 1991). There are minerals containing $\mathrm{Zn}$ among olivines and pyroxenes, e.g. acmiteaugite, and amphiboles, e.g. riebeckite. Also 2:1 clay minerals, mainly trioctahedral micas, contain $\mathrm{Zn}$ owing to isomorphic substitution of $\mathrm{Mg}$ or $\mathrm{Fe}$ ions for $\mathrm{Zn}$ at octahedral sites (RANKAMA and SAHAMA 1950, LINDSAY 1972, HUANG 1989). A substantial part of total $\mathrm{Zn}$ in soil occurs in clay and silt size particles (SHUMAN 1985), and total $\mathrm{Zn}$ content correlates with the content of clay or clay plus silt (SipPOla 1974, Schlichting and Elgala 1975, TJELL and Hovmand 1978, BAGHDADY and SIPPOLA 1983, LIANG et al. 1990). Zinc is released into the soil solution from mineral structures through weathering reactions as $\mathrm{Zn}^{2+}$ cation which is further adsorbed by various soil constituents and utilized by living organisms.

The significance of $\mathrm{Zn}$ as a nutrient of higher plants was shown in 1926 by SOMMER and LIPMAN. Zinc is involved in several enzymatic reactions of protein and carbohydrate metabolism of plants (MARSCHNER 1986). Zinc deficiency in crop production is extensive in calcareous soils (SILLANPÄÄ 1982), but insufficient $\mathrm{Zn}$ supply to dryland crops occurs also in acid soils for example in several states of the USA (JUNUS and COX 1987, BOSWELL et al. 1989), Brazil (LINS and Cox 1988), Australia (BRENNAN and GARTRELL 1990) and Zambia (BANDA and SINGH 1989). Zinc deficiency induced by liming has also been reported (KOWALENKO et al. 1980, MACNAEIDHE et al. 1986, MYHR 1988). In Finland, the average $\mathrm{Zn}$ concentration of timothy ranges from 24 to $32 \mathrm{mg} \mathrm{kg}^{-1}$ (LAKANEN 1969, KÄHÄRI and NISSINEN 1978) and in cereal grains from 26 to $36 \mathrm{mg} \mathrm{kg}^{-1}$ (JAAKKOLA and VOGT 1978, VARO et al. 1980) although means as high as $54 \mathrm{mg}$ $\mathrm{kg}^{-1}$ have been reported in cereals (PESSI et al. 1974, SYVÄLAHTI and KORKMAN 1978). The Zn concentration in the crops of Finland is above the minimum physiological requirement of gramineous plants or clover, $10-20 \mathrm{mg} \mathrm{kg}^{-1}$ of plant dry matter (e.g. MARSCHNER 1986, BRENNAN and GARTRELL 1990, CARSKY and REID 1990). Hence Zn applica- tions have not increased yields in field experiments with cereals and forage crops (JAAKKOLA and VOGT 1978, SYVÄLAHTI and KORKMAN 1978, SILLANPÄÄ 1990). However, Zn concentration of crops grown in Finland is almost always below 50 $\mathrm{mg} \mathrm{kg}^{-1}$, a desirable level in the fodder of ruminants (NJF 1975, SALO et al. 1990).

Worldwide, annual industrial consumption of $\mathrm{Zn}$ ranks fifth among metals after $\mathrm{Fe}, \mathrm{Al}, \mathrm{Mn}$ and $\mathrm{Cu}$ (Kabata-Pendias and Pendias 1984). In Finland, 160000 tons of $\mathrm{Zn}$ is manufactured annually (Tilastokeskus 1992), and $20 \%$ is consumed in the domestic markets mainly in galvanization (S. Karlman 1991, Outokumpu Oy, pers. commun.). Zinc is dispersed in the environment as emissions of metal industry and through the use of $\mathrm{Zn}$-containing products. Elevated contents of $\mathrm{Zn}$ are found in soils of industrial areas, especially around $\mathrm{Zn}$ mines (BERGHOLM and STEEN 1989), smelters (ANDERSSON and NILSSON 1976, ELSOKKARY and LÅG 1978, MiLLER and McFEE 1983), along highways (DELAUNE et al. 1989), under electric pylons (AL HIYALY et al. 1990) and in urban areas in general (SALOMONS 1984) owing to traffic and combustion of fossil fuels (CASS and McRAE 1983). Sludge application also gives rise to elevated $\mathrm{Zn}$ contents of soil (WIKLANDER and VAHTRAS 1977, CHRISTIE and BEATTIE 1989). Atmospheric deposition of anthropogenic origin is considered a major source of $\mathrm{Zn}$ input to the soil of rural areas in southern Sweden and western Norway (ÖBLAD and SELIN 1986, STEINNESS et al. 1989). The annual precipitation in southern and central Sweden and Finland is 100 $140 \mathrm{~g} \mathrm{Zn} \mathrm{ha}^{-1}$ (Ross 1987, ERVIÖ et al. 1990) and an increasing accumulation of $\mathrm{Zn}$ in lake sediments of Finland has been observed during the last 100 years (MYllymaA and MURTONIEMI 1986, VerTA et al. 1989).

Zinc input into the cultivated soils of Finland has probably increased over time, but intensified cultivation has elevated $\mathrm{Zn}$ uptake by the crop especially in grasslands (RINNE et al. 1974). A decrease of soil $\mathrm{Zn}$ concentration in northern Finland has been observed in timothy fields when the same fields were analyzed in 1974 and again 14 years 
later (ERVIÖ et al. 1990). This has been regarded as an indication of gradual decline of plant-available $\mathrm{Zn}$ in intensive grassland cultivation. Also farmlevel observations indicate insufficient supply of $\mathrm{Zn}$ to crop or domestic animals. Grasslands on peat soils have commonly shown poor growth after 10 years of intensive cultivation, and $\mathrm{Zn}$ deficiency has been suggested as an explanation to this (URVAS and SOINI 1984). In northern Finland, cattle have exhibited symptoms of $\mathrm{Zn}$ deficiency which disappeared with $\mathrm{Zn}$ injections. One way of contributing to a sufficient $\mathrm{Zn}$ supply to the cattle would be the elevation of the $\mathrm{Zn}$ content of forage crops and fodder cereals by $\mathrm{Zn}$ fertilization.

Zinc fertilization is in Finland recommended especially to fodder crops (Viljavuuspalvelu 1992). Before 1982, less than $30000 \mathrm{~kg}$ of $\mathrm{Zn}$ (below $15 \mathrm{~g}$ $\mathrm{ha}^{-1}$ ) was applied annually in mineral fertilizers. The first macronutrient fertilizer (18-3-12\% N-P$\mathrm{K})$ containing also $0.3 \% \mathrm{Zn}$ was introduced in 1982 and a separate granular $\mathrm{Zn}$ fertilizer in 1984. Since $1982,180000-420000 \mathrm{~kg}$, or $80-210 \mathrm{~g} \mathrm{Zn} \mathrm{ha}^{-1}$ has been spread annually in mineral fertilizers, more than $90 \%$ of which incorporated in macronutrient fertilizers (Kemira 1992). The principal areas of fertilizer $\mathrm{Zn}$ consumption have been the provinces of Vaasa, Mikkeli, Kuopio and especially the provinces of Oulu and Lappi where $500 \mathrm{~g} \mathrm{Zn} \mathrm{ha}^{-1}$, as compared to $20-50 \mathrm{~g} \mathrm{ha}^{-1}$ in the southernmost provinces, has been applied annually in chemical fertilizers. Even though field experiments on $\mathrm{Zn}$ fertilization have been carried out in Finland, the influence of soil characteristics on the response to applied $\mathrm{Zn}$ has not been investigated previously. Neither has the efficiency of different commercial $\mathrm{Zn}$ fertilizers been compared.

The purpose of the present investigation was to examine the content and solubility of $\mathrm{Zn}$ in cultivated soils of Finland and the effect of $\mathrm{Zn}$ fertilizers on cultivated plants. Information on the soil characteristics controlling the solubility and plant-availability of native and added $\mathrm{Zn}$ was sought. The study did not concentrate on soils suspected to be poor in $\mathrm{Zn}$; the soil material collected represented all kinds of cultivated soils of Finland. The emphasis was in the plough layer, but the vertical distribution of $\mathrm{Zn}$ was also investigated. In addition to the characterization of soil $\mathrm{Zn}$ by soil analyses, the availability of soil $\mathrm{Zn}$ was studied in a pot experiment. The effect of $\mathrm{Zn}$ application on the $\mathrm{Zn}$ content of forage was examined in pot and field experiments. Also barley, the most important fodder cereal in Finland, was included in the field experiments. The ability of soil analysis to explain $\mathrm{Zn}$ uptake by ryegrass and to predict the response of plant $\mathrm{Zn}$ concentration to $\mathrm{Zn}$ applications was critically studied in pot experiments. In field experiments, the efficiency of different $\mathrm{Zn}$ fertilizers and application methods were compared, not forgetting environmental aspects.

\section{METHODS OF ANALYSIS}

\subsection{Testing the methods of soil $\mathrm{Zn}$ determination}

Soils from a material of 13 cultivated soils (Appendix 1) were mainly used for testing the methods of soil analysis. A few soils from a larger material (Appendix 2) were occasionally used.

\subsubsection{Total Zn}

In order to determine the total $\mathrm{Zn}$ content $\left(\mathrm{Zn}_{\text {tot }}\right)$ in the soil, the solid matrix needs to be dissolved. Hydrofluoric acid (HF) is required for complete decomposition of silicate minerals, and perchloric acid $\left(\mathrm{HClO}_{4}\right)$ is a strong oxidizing agent for organic materials. Procedures with and without these hazardous chemicals were tested for the digestion of $\mathrm{Zn}_{\text {tot }}$.

In the aqua regia procedure (1), a $300-\mathrm{mg}$ soil sample (four replicates) was digested with $4 \mathrm{ml}$ of aqua regia $\left(\mathrm{AR}, 1 \mathrm{ml}\right.$ of concentrated $\mathrm{HNO}_{3}$ and 3 $\mathrm{ml}$ of concentrated $\mathrm{HCl}$ ). The sample was heated for 2 hours in a platinum crucible on a hot plate and 
allowed to react overnight. The next morning the residue was washed with warm dilute $\mathrm{HCl}$ into a volumetric flask. In the procedure of LIM and JACKSON (1982) employing aqua regia and HF (2), a 300-mg soil sample (four replicates) was digested with $4 \mathrm{ml}$ of $\mathrm{AR}$ for 2 hours at $200^{\circ} \mathrm{C}$ in a $100-\mathrm{ml}$ volumetric flask in a sand bath. Thereafter, $5 \mathrm{ml}$ of $\mathrm{HF}$ was added and digestion was continued for 1 hour after which $50 \mathrm{ml}$ of saturated $\mathrm{H}_{3} \mathrm{BO}_{3}$ was added to dissolve the possibly precipitated metal fluorides. After cooling, the bottle was filled with deionized water. In the $\mathrm{HNO}_{3}-\mathrm{HF}-\mathrm{H}_{2} \mathrm{SO}_{4}$ procedure (3), a 500-mg soil sample (four replicates) was digested with $20 \mathrm{ml}$ of $\mathrm{HNO}_{3}$ in a teflon crucible on a hot plate until dry. Then, $5 \mathrm{ml}$ of $\mathrm{H}_{2} \mathrm{SO}_{4}$ and $15 \mathrm{ml}$ of $\mathrm{HF}$ were added and evaporated to dryness. In order to completely remove fluoride, $5 \mathrm{ml}$ of concentrated $\mathrm{H}_{2} \mathrm{SO}_{4}$ was added and evaporated to dryness. The residue was washed into a volumetric flask with warm dilute $\mathrm{HCl}$. From three soils, AR dissolved $55-70 \%$ of the quantity of $\mathrm{Zn}$ dissolved by the two mixtures containing HF (Table 1).

In an experiment with 12 surface soils $(4,11,23$, $30,32,35,60,61,67,69,88,105$ in Appendix 2), the effect of $\mathrm{HClO}_{4}$ addition was tested in the

Table 1. Soil $\mathrm{Zn}$ dissolved by aqua regia (AR), AR-HF and $\mathrm{HNO}_{3}-\mathrm{HF}-\mathrm{H}_{2} \mathrm{SO}_{4} \cdot{ }^{1}$

\begin{tabular}{lccc}
\hline Soil & \multicolumn{3}{c}{$\mathrm{Zn}\left(\mathrm{mg} \mathrm{kg}^{-1}\right)$ dissolved by } \\
\cline { 2 - 4 } & $\mathrm{AR}$ & $\mathrm{AR}-\mathrm{HF}$ & $\begin{array}{c}\mathrm{HNO}_{3}-\mathrm{HF}- \\
\mathrm{H}_{2} \mathrm{SO}_{4}\end{array}$ \\
\hline 209 Very fine sand & $46.0^{\mathrm{b}}$ & $82.8^{\mathrm{a}}$ & $82.8^{\mathrm{a}}$ \\
211 Fine sand & $40.3^{\mathrm{b}}$ & $72.1^{\mathrm{a}}$ & $70.1^{\mathrm{a}}$ \\
212 Mull & $50.2^{\mathrm{b}}$ & $76.4^{\mathrm{a}}$ & $71.7^{\mathrm{a}}$ \\
\hline
\end{tabular}

${ }^{1}$ Results of each soil were tested separately. Means marked with the same superscript do not differ at $\mathrm{P}=0.05$.

Table 2. Recovery of $\mathrm{Zn}$ added to a mull soil (212) digested according to the $\mathrm{HNO}_{3}-\mathrm{HClO}_{4}-\mathrm{HF}-\mathrm{H}_{2} \mathrm{SO}_{4}$ procedure.'

\begin{tabular}{lrcr}
\hline $\mathrm{Zn}$ addition & \multicolumn{2}{c}{$\mathrm{Zn}$} & \multicolumn{2}{c}{ Recovery of added $\mathrm{Zn}$} \\
\cline { 3 - 4 } $\mathrm{mg} \mathrm{kg}^{-1}$ & $\mathrm{mg} \mathrm{kg}^{-1}$ & $\mathrm{mg} \mathrm{kg}^{-1}$ & $\%$ \\
\hline 0 & $74.9^{\mathrm{c}}$ & - & - \\
50 & $122.7^{\mathrm{b}}$ & 47.8 & 96 \\
100 & $168.6^{\mathrm{a}}$ & 93.7 & 94 \\
\hline
\end{tabular}

${ }^{1}$ Means marked with different superscripts differ at $\mathrm{P}=0.05$.
$\mathrm{HNO}_{3}-\mathrm{HF}-\mathrm{H}_{2} \mathrm{SO}_{4}$ procedure. After the digestion with $\mathrm{HNO}_{3}, 3 \mathrm{ml}$ of $\mathrm{HClO}_{4}$ and $3 \mathrm{ml}$ of $\mathrm{H}_{2} \mathrm{SO}_{4}$ were added and warmed until fumes evolved and heating was continued for 10 more minutes. Then, $\mathrm{HF}$ and $\mathrm{H}_{2} \mathrm{SO}_{4}$ were added as described above. Inclusion of the additional digestion phase into the procedure increased the average quantities of $\mathrm{Zn}$ extracted from 82.2 to $84.6 \mathrm{mg} \mathrm{kg}^{-1}$ ( $\left.+2.9 \%\right)$. According to the paired t-test, the difference was not statistically significant $\left(\mathrm{t}=1.856^{\mathrm{n} . \mathrm{s}}\right)$, but in further digestions also $\mathrm{HClO}_{4}$ was added in order to ensure effective oxidation of organic matter.

An experiment was carried out to study possible $\mathrm{Zn}$ loss and contamination during the digestion procedure. Portions $(500 \mathrm{mg})$ of carefully homogenized mull soil (212) were weighed into nine teflon crucibles. Next, 1) $10 \mathrm{ml}$ of water, 2) $5 \mathrm{ml}$ of a solution containing $5 \mathrm{mg} \mathrm{Zn} \mathrm{dm}^{-3}$ as $\mathrm{ZnSO}_{4} \cdot 7 \mathrm{H}_{2} \mathrm{O}$ $\left(\mathrm{ZnSO}_{4}\right)$ plus $5 \mathrm{ml}$ of water and 3) $10 \mathrm{ml}$ of the $\mathrm{Zn}$ solution were pipetted into three crucibles each. The quantities of $\mathrm{Zn}$ added were 0,50 and $100 \mathrm{mg}$ $\mathrm{kg}^{-1}$ of soil, respectively. The soil samples were digested according to the $\mathrm{HNO}_{3}-\mathrm{HClO}_{4}-\mathrm{HF}$ $\mathrm{H}_{2} \mathrm{SO}_{4}$ procedure as described above, and the $\mathrm{Zn}$ concentration in the digests was determined. No marked net loss or contamination occurred during the digestion (Table 2).

\subsubsection{Fractionation of soil $\mathrm{Zn}$}

In order to characterize the chemical forms of soil $\mathrm{Zn}$, it is commonly separated into fractions differing in solubility. The fractionation makes the basis for the estimation of potentially mobile $\mathrm{Zn}$ reserves and availability of soil $\mathrm{Zn}$ to plants. The sizes of the fractions are defined operationally as quantities of $\mathrm{Zn}$ which are extracted, often sequentially, with solutions supposed to displace $\mathrm{Zn}$ from the exchange complex or dissolve certain soil components resulting in a solubilization of $\mathrm{Zn}$ retained by them. The following fractions are commonly distinguished: (1) $\mathrm{Zn}$ in the soil solution, (2) exchangeable $\mathrm{Zn}$, (3) adsorbed, chelated or complexed $\mathrm{Zn}$, (4) $\mathrm{Zn}$ in secondary clay minerals and insoluble metal oxides, and (5) residual $\mathrm{Zn}$ bound by primary minerals (VIETS 1962). 
There are no specific extractants for $\mathrm{Zn}$, but various solutions are used for a simultaneous extraction of several elements, e.g. $\mathrm{Zn}, \mathrm{Cu}, \mathrm{Mn}, \mathrm{Fe}, \mathrm{Al}, \mathrm{Ni}, \mathrm{Co}$. The sequential extraction procedures are usually combinations of single extraction methods developed earlier for specific purposes. The most frequently applied procedure in non-calcareous soils utilizes neutral salt solutions (e.g. $0.05 \mathrm{M} \mathrm{CaCl}_{2}, 1$ $\left.\mathrm{M} \mathrm{MgCl}_{2}\right)$ to extract water-soluble and exchangeable $\mathrm{Zn}$, pyrophosphate solutions $\left(0.1 \mathrm{M} \mathrm{K}_{4} \mathrm{P}_{2} \mathrm{O}_{7}\right.$ or $\mathrm{Na}_{4} \mathrm{P}_{2} \mathrm{O}_{7}$ ) for the extraction of $\mathrm{Zn}$ bound by organic matter, and ammonium oxalate - oxalic acid solutions for the dissolution of $\mathrm{Zn}$ bound by $\mathrm{Fe}, \mathrm{Al}$ and Mn oxides (sesquioxides). This procedure was first used for the fractionation of soil Cu (McLAREN and CRAWFORD 1973) and has later been used also for the fractionation of $\mathrm{Zn}$ in non-calcareous soils (ELSOKKARY and LÅG 1978, IYENGAR et al. 1981, BJERRE and SHIERUP 1985, HAYNES and SWIFT 1985, LiANG et al. 1990). $\mathrm{H}_{2} \mathrm{O}_{2}$ or $\mathrm{NaOCl}$ may be used instead of pyrophosphate for the dissolution of $\mathrm{Zn}$ bound by organic matter (SHUMAN 1979, NIELSEN et al. 1986, SIMS 1986, SINGH et al. 1988). A common feature for all the fractionation procedures is that residual $\mathrm{Zn}\left(\mathrm{Zn}_{\text {res }}\right)$, remaining in the soil after removal of oxide-bound $\mathrm{Zn}$ and consisting mainly of $\mathrm{Zn}$ in the primary minerals, is dissolved with concentrated acids according to the same procedures as used in the digestion of $\mathrm{Zn}_{\text {tot }}$.

The same fractionation procedure is seldom used in more than one study, which complicates the comparison of results. Depending on the research objectives, different fractions are determined. In some studies a fraction of $\mathrm{Zn}$ supposed to be specifically adsorbed on inorganic sites has been extracted by $2.5 \%$ acetic acid (ELSOKKARY and LÅG 1978, IYENGAR et al. 1981, BJERRE and SHIERUP 1985 ) or $\mathrm{Pb}\left(\mathrm{NO}_{3}\right)_{2}$ (LIANG et al. 1990). Further, $\mathrm{Zn}$ bound by Mn oxide has been extracted together with $\mathrm{Zn}$ bound by $\mathrm{Fe}$ and $\mathrm{Al}$ oxides (ELSOKKARY and LÅG 1978, SHUMAN 1979) or separately (SIMS and PATRICK 1978, IYENGAR et al. 1981, MILLER and McFeE 1983, Shuman 1985, Sims 1986, LiANG et al. 1990). Zinc bound by poorly crystalline $\mathrm{Fe}$ and $\mathrm{Al}$ oxides can be extracted separately from $\mathrm{Zn}$ bound by crystalline oxides (MILLER and McFeE 1983, Shuman 1985, Sims 1986) as op- posed to extracting only one fraction, referring to $\mathrm{Zn}$ bound by oxide materials. In addition to differences in the extracting solutions, the same soil sample may be used throughout the procedure (ELSOKKARY and LÅG 1978, SHUMAN 1979, NIELSEN et al. 1986) or after the determination of water-soluble and exchangeable $\mathrm{Zn}$ a new sample is weighed for the determination of the more sparingly soluble secondary fractions (SIMS and PATRICK 1978, IYENGAR et al. 1981).

In the present study, $\mathrm{MgCl}_{2}$ solution was used for the extraction of water-soluble and exchangeable $\mathrm{Zn}, \mathrm{K}_{4} \mathrm{P}_{2} \mathrm{O}_{7}$ for the extraction of $\mathrm{Zn}$ bound by organic matter and oxalate for the dissolution of $\mathrm{Zn}$ bound by $\mathrm{Fe}, \mathrm{Al}$ and $\mathrm{Mn}$ oxides. The residual $\mathrm{Zn}$ was digested by the $\mathrm{HNO}_{3}-\mathrm{HClO}_{4}-\mathrm{HF}-\mathrm{H}_{2} \mathrm{SO}_{4}$ procedure.

\section{a. Water-soluble and exchangeable $\mathrm{Zn}$}

Zinc cations $\left(\mathrm{Zn}^{2+}\right)$ can be retained by the negatively charged sites by non-specific electrostatic forces. This fraction of $\mathrm{Zn}$ is exchangeable with other cations. For theoretical reasons, $\mathrm{Mg}^{2+}$ salts have been considered suitable in the extractants for exchangeable $\mathrm{Zn}^{2+}$ because the two cations are similar in radius and charge. It is therefore supposed that $\mathrm{Mg}^{2+}$ effectively displaces exchangeable $\mathrm{Zn}^{2+}$ from soil surfaces into the solution. Water-soluble $\mathrm{Zn}$ is simultaneously extracted. The $1 \mathrm{M} \mathrm{MgCl}_{2}$ was first used for the determination of plant-available $\mathrm{Zn}$ by STEWART and BERGER (1965) and MARTENS (1968). In those days, concentration of $\mathrm{Zn}$ was measured colorimetrically. Since the 1970's, $\mathrm{Zn}$ has invariably been determined by atomic absorption spectrophotometry (AAS) where a high salt concentration in the solution analyzed may cause a high background absorption as well as crusting of the burner. Owing to low concentration of $\mathrm{Zn}$ in the extract, dilution as a means of reducing the salt concentration may not be feasible. Therefore the use of less concentrated salt solutions as extractants would be desirable.

The effect of $\mathrm{MgCl}_{2}$ concentration on the extraction of $\mathrm{Zn}$ from eight soils (201, 203, 204, 206, 209 and 210 in Appendix 1; 10 and 73 in Appendix 2) was studied. Soil samples (10 g, two replicates) 
were shaken for 2 hours with 25-ml aliquots of $1 \mathrm{M}$ or $0.5 \mathrm{M} \mathrm{MgCl}_{2}$ solution. The suspensions were filtered and analyzed for $\mathrm{Zn}$. The means and ranges of $\mathrm{Zn}$ extracted $\left(\mathrm{mg} \mathrm{kg}^{-1}\right)$ were as follows:

$\begin{array}{lll}\text { Solution } & \text { Mean } & \text { Range } \\ 1 \mathrm{M} & 1.71 & 1.2-2.7 \\ 0.5 \mathrm{M} & 1.13 & 0.7-2.0\end{array}$

The less concentrated solution extracted $65 \%$ (range $53-74 \%$ ) of that extracted with the $1 \mathrm{M}$ solution. According to the paired t-test, the difference between the quantities of $\mathrm{Zn}$ extracted with the two solutions was highly significant $(\mathrm{t}=$ $\left.14.758^{* * *}\right)$, but the results correlated closely $(\mathrm{r}=$ $0.99^{* * *}$ ). The mean deviation of the two replicates was $5.2 \%$, range $0.3-22.2 \%$.

The recovery of added $\mathrm{Zn}$ was studied on the extract obtained from soil 201 with $0.5 \mathrm{M} \mathrm{MgCl}_{2}$ at the soil-to-solution ratio of 1:5 (weight/volume, $\mathrm{w} / \mathrm{v})$. Into three $180-\mathrm{ml}$ portions of the extract, obtained by combining extracts of several subsamples, 20-ml aliquots of water or solution of $\mathrm{ZnSO}_{4}$ were added to produce concentrations theoretically differing by 0.05 and $0.20 \mathrm{mg} \mathrm{Zn} \mathrm{dm}^{-3}$. The measured concentrations (four subsamples) showed accurate recovery of added $\mathrm{Zn}$ (Table 3).

\section{b. Zinc bound by organic matter}

The use of pyrophosphate solution as the extractant for $\mathrm{Zn}$ bound by organic matter is based on the ability of pyrophosphate to solubilize humic substances (BREMNER and LEES 1949, MORTVEDT and OSBORN 1977) and on the ability of pyrophosphate anion to form soluble complexes with $\mathrm{Zn}$ (ASHER and BAR-YOSEF 1982, BAR-YOSEF and ASHER 1983). It has been hypothesized that polyvalent cations complexed to organic matter are responsible for keeping organic matter in a flocculated and water-insoluble state. These cations can be removed by complexing with pyrophosphate anion, resulting also in the solubilization of humus (STEVENSON 1982, p. 40). However, the mechanism responsible for the solubilization of humic substances and cations in the pyrophosphate extraction has not been fully established (BORGGAARD 1988).

Recovery of $\mathrm{Zn}$ added into the pyrophosphate extracts of a mull soil (212) was studied. Soil samples were shaken with $0.1 \mathrm{M} \mathrm{K}_{4} \mathrm{P}_{2} \mathrm{O}_{7}(\mathrm{pH} 10)$ at the soil-to-solution ratio of 1:25 (w/v) for 18 hours, and the suspensions were centrifuged. Zinc was added to the extracts as has been described earlier. Added Zn was accurately recovered (Table 3 ).

The commercial $\mathrm{K}_{4} \mathrm{P}_{2} \mathrm{O}_{7}$ chemical contained 6 $\mathrm{mg} \mathrm{Zn} \mathrm{kg}{ }^{-1}$ resulting in a $\mathrm{Zn}$ concentration of 0.2 $\mathrm{mg} \mathrm{dm}^{-3}$ in the $0.1 \mathrm{M}$ solution. It is possible to purify the reagent with a solvent extraction (SHUMAN 1979) or with a cation exchange resin (SHUMAN 1985). However, the reagent may be used without purification if $\mathrm{Zn}$ in the extraction solution remains completely in the liquid phase during the extraction. The influence of $\mathrm{Zn}$ in the pyrophosphate reagent was indirectly examined with four surface soils (Appendix 2) by studying the adsorption of added $\mathrm{Zn}$ to soil suspended in the $0.1 \mathrm{M}$ $\mathrm{K}_{4} \mathrm{P}_{2} \mathrm{O}_{7}$ solution ( $\mathrm{pH} 10$ ). In the experiment, 2.5-g soil samples (four replicates) were shaken for 18 hours in the following solutions:
1) $0.1 \mathrm{M} \mathrm{K}_{4} \mathrm{P}_{2} \mathrm{O}_{7}$
2) $0.1 \mathrm{M} \mathrm{K}_{4} \mathrm{P}_{2} \mathrm{O}_{7}+0.2 \mathrm{mg} \mathrm{Zn} \mathrm{dm}{ }^{-3}$ as $\mathrm{ZnCl}_{2}$
3) $0.1 \mathrm{M} \mathrm{K}_{4} \mathrm{P}_{2} \mathrm{O}_{7}+0.4 \mathrm{mg} \mathrm{Zn} \mathrm{dm}{ }^{-3}$ as $\mathrm{ZnCl}_{2}$

Table 3. Recovery of $\mathrm{Zn}$ added to $0.5 \mathrm{M} \mathrm{MgCl}_{2}$, pyrophosphate and oxalate extracts.

\begin{tabular}{|c|c|c|c|c|c|c|}
\hline \multirow{2}{*}{$\begin{array}{l}\text { Zn addition } \\
\mathrm{mg} \mathrm{dm}{ }^{-3}\end{array}$} & \multicolumn{2}{|c|}{$\mathrm{MgCl}_{2}^{1}$} & \multicolumn{2}{|c|}{ Pyrophosphate $^{2}$} & \multicolumn{2}{|c|}{ Oxalate $^{2}$} \\
\hline & $\mathrm{Zn}, \mathrm{mg} \mathrm{dm}^{-3}$ & Recovery, $\%$ & $\mathrm{Zn}, \mathrm{mg} \mathrm{dm}-3$ & Recovery, $\%$ & $\mathrm{Zn}, \mathrm{mg} \mathrm{dm}^{-3}$ & Recovery, $\%$ \\
\hline 0 & 0.02 & - & 0.15 & - & 0.34 & - \\
\hline 0.05 & 0.07 & 98 & - & - & - & - \\
\hline 0.20 & 0.22 & 101 & 0.35 & 102 & 0.54 & 100 \\
\hline 0.40 & - & - & 0.55 & 101 & 0.75 & 101 \\
\hline
\end{tabular}

${ }^{1}$ Extract of soil 201

${ }^{2}$ Extract of soil 212 
Table 4. Effect of $\mathrm{Zn}$ addition to the pyrophosphate solution on the concentrations of $\mathrm{Zn}$ measured in the soil extract.

\begin{tabular}{|c|c|c|c|c|}
\hline \multirow[t]{2}{*}{ Soil } & \multirow{2}{*}{$\begin{array}{c}\mathrm{Zn} \text { added to } \\
\text { the extracant, } \\
\mathrm{mg} \mathrm{dm} \mathrm{m}^{-3}\end{array}$} & \multirow{2}{*}{$\begin{array}{l}\mathrm{Zn} \text { in the } \\
\text { extract, } \\
\mathrm{mg} \mathrm{dm}^{-3}\end{array}$} & \multicolumn{2}{|c|}{$\begin{array}{c}\text { Recovery of } \\
\text { added } \mathrm{Zn}\end{array}$} \\
\hline & & & $\mathrm{mg} \mathrm{dm}^{-3}$ & $\%$ \\
\hline $18^{1}$ & 0 & 0.11 & - & - \\
\hline Clay & 0.20 & 0.31 & 0.20 & 98 \\
\hline loam & 0.39 & 0.50 & 0.39 & 99 \\
\hline $34^{\prime}$ & 0 & 0.23 & - & - \\
\hline \multirow[t]{2}{*}{ Loam } & 0.21 & 0.45 & 0.22 & 101 \\
\hline & 0.45 & 0.69 & 0.45 & 100 \\
\hline $78^{1}$ & 0 & 0.29 & - & 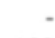 \\
\hline \multirow{2}{*}{ Mull } & 0.24 & 0.53 & 0.24 & 100 \\
\hline & 0.46 & 0.76 & 0.47 & 102 \\
\hline $104^{\prime}$ & 0 & 0.84 & - & - \\
\hline Carex & 0.24 & 1.09 & 0.24 & 103 \\
\hline peat & 0.46 & 1.35 & 0.51 & 111 \\
\hline
\end{tabular}

I Soils from the surface soil material (Appendix 2)

Zinc additions to the extractant corresponded to $4.1-9.2 \mathrm{mg} \mathrm{Zn} \mathrm{kg}^{-1}$ of soil and were recovered in the extract (Table 4), showing that added $\mathrm{Zn}$ was not adsorbed by the soil. The results are in agreement with those of ASHER and BAR-YOSEF (1982) who observed that at $\mathrm{pH} 9 \mathrm{Zn}$ was not adsorbed onto a Ca-montmorillonite suspended in a 0.0096 M pyrophosphate solution containing $8.0 \mathrm{mg} \mathrm{Zn}$ $\mathrm{dm}^{-3}$. It can thus be concluded that $\mathrm{Zn}$ of the commercial chemical is not adsorbed either but only gives rise to a high background absorption. The 0.1 $\mathrm{M} \mathrm{K}_{4} \mathrm{P}_{2} \mathrm{O}_{7}$ was therefore used in the extraction of $\mathrm{Zn}$ without purification.

\section{c. Zinc bound by sesquioxides}

Since the work of TAMM (1922), acid oxalate solutions have been widely used for the extraction of $\mathrm{Fe}$ and $\mathrm{Al}$ oxides in soil. In the dark, acid oxalate is supposed to extract only poorly crystalline oxides; in UV light, also crystalline Fe oxide is extracted. The oxalate solutions are assumed to dissolve components occluded into the $\mathrm{Fe}$ and $\mathrm{Al}$ oxides, and oxalate has therefore been used for the extraction of soil $\mathrm{Zn}$. To avoid crusting of the burner of AAS, a $0.05 \mathrm{M}$ oxalate solution was selected instead of more concentrated solutions commonly used in the fractionation procedures.

The extraction of $\mathrm{Zn}$ from four soils with $0.05 \mathrm{M}$ oxalate solutions was investigated at $\mathrm{pH}$ 2.0, 2.9, 3.3 and 4.0. The $\mathrm{pH}$ values were created by different ratios of oxalic acid and ammonium oxalate. Before the oxalate treatment, the samples $(2.5 \mathrm{~g}$, four replicates) were extracted with pyrophosphate and washed with water. The remaining samples were shaken for 4 hours with 50 -ml aliquots of the four oxalate solutions, the suspensions were centrifuged and the extracts analyzed for $\mathrm{Zn}$. The solution which had the lowest $\mathrm{pH}$ was the most efficient extractant for $\mathrm{Zn}$ (Table 5), probably owing to a substantial dissolution of structural $\mathrm{Zn}$. There was a considerable decrease in the extractability of $\mathrm{Zn}$ in three soils with an elevation of $\mathrm{pH}$ from 2.0 to 2.9, but an additional increase in $\mathrm{pH}$ affected the results less markedly. A solution of $\mathrm{pH} 2.9(0.024 \mathrm{M}$ and $0.026 \mathrm{M}$ in oxalic acid and ammonium oxalate, respectively) was used in the rest of the oxalate extractions.

The recovery of $\mathrm{Zn}$ added to the oxalate extract obtained from a mull (212) was studied. Prior to oxalate extraction the soil samples $(2.5 \mathrm{~g})$ were shaken with pyrophosphate and washed with water. The remaining samples were shaken in 50-ml aliquots of $0.05 \mathrm{M}$ oxalate ( $\mathrm{pH} 2.9$ ) for 4 hours and the suspensions were centrifuged. Zinc was added to

Table 5. Soil $\mathrm{Zn}$ extracted by $0.05 \mathrm{M}$ oxalate at different $\mathrm{pH}$ values.

\begin{tabular}{lccccc}
\hline Soil & \multicolumn{3}{c}{ Zn $\left(\mathrm{mg} \mathrm{kg}^{-1}\right)$ extracted at pH } & \multicolumn{2}{c}{ HSD $_{0.05}$} \\
\cline { 2 - 5 } & 2.0 & 2.9 & 3.3 & 4.0 & $\mathrm{mg} \mathrm{kg}^{-1}$ \\
\hline 201 Fine sand & $3.1^{\mathrm{a}}$ & $2.4^{\mathrm{b}}$ & $2.1^{\mathrm{bc}}$ & $2.0^{\mathrm{c}}$ & 0.39 \\
209 Very fine sand & $4.1^{\mathrm{a}}$ & $2.5^{\mathrm{b}}$ & $2.5^{\mathrm{b}}$ & $2.0^{\mathrm{b}}$ & 0.63 \\
212 Mull & $2.7^{\mathrm{a}}$ & $1.5^{\mathrm{b}}$ & $1.4^{\mathrm{b}}$ & $1.1^{\mathrm{b}}$ & 0.64 \\
213 Mull & $2.0^{\mathrm{a}}$ & $1.7^{\mathrm{ab}}$ & $1.3^{\mathrm{bc}}$ & $1.1^{\mathrm{c}}$ & 0.42 \\
\hline
\end{tabular}

1 Results of each soil were tested separately. Means marked with the same superscript do not differ at $P=0.05$. 
the extracts as was described earlier. Added $\mathrm{Zn}$ was accurately recovered (Table 3 ).

\section{d. Repeated pyrophosphate extraction}

The effect of repeated pyrophosphate extraction on the quantities of $\mathrm{Zn}$ dissolved sequentially with oxalate was studied with two soils $(211,213)$. The 2.5 -g soil samples (four replicates) were extracted once, twice or three times with 50-ml aliquots of pyrophosphate, washed with water and extracted once with a 50-ml aliquot of oxalate $(\mathrm{pH} 2.9)$. In both soils, the first pyrophosphate treatment extracted more than did the second and the third treatment (Table 6). Repeated pyrophosphate extractions tended to reduce the quantities of $\mathrm{Zn}$ extracted by oxalate in the mull (213), suggesting that the two solutions dissolved $\mathrm{Zn}$ to some extent from a common pool. An alternative but less likely explanation is that part of the sample was lost in the successive washings, resulting in a smaller quantity of soil remaining in the oxalate extraction. The number of pyrophosphate extractions did not have a consistent effect on the results of the oxalate extraction in the mineral soil 211 . In soil 211 , the quantities of $\mathrm{Zn}$ extracted by oxalate were substantially larger than those dissolved with the second and third extraction by pyrophosphate. In this soil there was obviously

Table 6. Soil $\mathrm{Zn}$ extracted with one, two or three sequential treatments by pyrophosphate and a successive extraction by oxalate. I, II and III refer to the first, second and third pyrophosphate extraction.'

\begin{tabular}{|c|c|c|c|c|c|}
\hline \multirow{2}{*}{\multicolumn{2}{|c|}{ Soil }} & \multicolumn{3}{|c|}{$\begin{array}{l}\mathrm{Zn}\left(\mathrm{mg} \mathrm{kg}^{-1}\right) \text { extracted by } \\
\text { pyrophosphate }\end{array}$} & \multirow{2}{*}{$\begin{array}{c}\mathrm{Zn}\left(\mathrm{mg} \mathrm{kg}^{-1}\right) \\
\text { extracted } \\
\text { by oxalate }\end{array}$} \\
\hline & & I & II & III & \\
\hline \multirow[t]{4}{*}{211} & & $3.5^{a}$ & - & - & $2.2^{\mathrm{b}}$ \\
\hline & & $3.6^{a}$ & $0.7^{\mathrm{c}}$ & - & $2.5^{\mathrm{a}}$ \\
\hline & & $3.6^{\mathrm{a}}$ & $0.8^{b c}$ & $1.0^{\mathrm{b}}$ & $2.1^{\mathrm{b}}$ \\
\hline & $\mathrm{HSD}_{0.05}$ & 0.2 & & & 0.1 \\
\hline \multirow[t]{4}{*}{213} & & $5.1^{\mathrm{a}}$ & - & - & $1.6^{\mathrm{a}}$ \\
\hline & & $4.9^{a}$ & $1.4^{\mathrm{b}}$ & - & $1.4^{\mathrm{ab}}$ \\
\hline & & $4.9^{\mathrm{a}}$ & $1.4^{b}$ & $0.9^{c}$ & $1.2^{\mathrm{b}}$ \\
\hline & $\mathrm{HSD}_{0.05}$ & 0.2 & & & 0.2 \\
\hline
\end{tabular}

\footnotetext{
' Results of pyrophosphate and oxalate extractions were tested separately. The two soils were tested separately. Means marked with the same superscript do not differ at $\mathrm{P}=0.05$.
}

a pool of $\mathrm{Zn}$ which was extractable by oxalate but which was resistant even to repeated pyrophosphate washings.

\section{e. Reproducibility and additivity of the results of sequential extractions}

The reproducibility of the results of pyrophosphate and oxalate extractions was studied with 13 soils $(201,202,206,207,208,209,210,211$ and 212 in Appendix 1; 10, 73, 90 and 100 in Appendix 2). The 2.5 -g soil samples (two replicates) were extracted in sequence with $50-\mathrm{ml}$ aliquots of $0.1 \mathrm{M}$ pyrophosphate, washed with water and extracted with $50 \mathrm{ml}$ of $0.05 \mathrm{M}$ oxalate ( $\mathrm{pH} 2.9$ ). Another two replicates were sequentially extracted and analyzed for $\mathrm{Zn}$ a few days later. The results of the first extraction were designated Py 1 and $\mathrm{Ox} 1$, those of the second extraction Py 2 and $\mathrm{Ox} 2$. The differences between Py $1\left(5.12 \mathrm{mg} \mathrm{kg}^{-1}\right)$ and Py $2\left(5.20 \mathrm{mg} \mathrm{kg}^{-1}\right)$ as well as between $\mathrm{Ox} 1\left(2.15 \mathrm{mg} \mathrm{kg}^{-1}\right)$ and $\mathrm{Ox} 2(2.17 \mathrm{mg}$ $\mathrm{kg}^{-1}$ ) were not statistically significant according to the paired t-test. In the 13 soils, the difference between the two means of $\mathrm{Zn}_{\text {py }}$ ranged from -0.65 to $0.38 \mathrm{mg} \mathrm{kg}^{-1}$ and that of $\mathrm{Zn}_{\text {ox }}$ from -0.30 to 0.25 $\mathrm{mg} \mathrm{kg}^{-1}$. The coefficient of variation of the four individual determinations in the 13 soils ranged 2.8 $-12.4 \%$ (mean $5.3 \%$ ) and $0.6-13.4 \%$ (mean $4.5 \%$ ) for $\mathrm{Zn}_{\text {py }}$ and $\mathrm{Zn}_{\mathrm{ox}}$, respectively.

In sequential fractionation procedures part of the sample may be lost during the numerous decantations. In order to study the importance of this source of error, 2.5-g samples (four replicates) of 13 soils were sequentially extracted by pyrophosphate for 18 hours, washed with water and extracted by oxalate for 4 hours. After the oxalate extraction, the remaining sample was washed with water, dried and ground, and a 500-mg sample (two replicates) was digested according to the $\mathrm{HNO}_{3}-\mathrm{HClO}_{4}-\mathrm{HF}$ - $\mathrm{H}_{2} \mathrm{SO}_{4}$ procedure, and residual $\mathrm{Zn}\left(\mathrm{Zn}_{\text {res }}\right)$ was measured. Also $\mathrm{Zn}_{\text {tot }}$ (two replicates) was determined. The sums of $\mathrm{Zn}_{\text {py }}, \mathrm{Zn}_{\text {ox }}$ and $\mathrm{Zn}_{\text {res }}$ were compared with $\mathrm{Zn}_{\text {tot }}$ (Table 7). In seven soils the sum of fractions was higher $\left(1.1-13.6 \mathrm{mg} \mathrm{kg}^{-1}, 2\right.$ $11 \%$ ) than $\mathrm{Zn}_{\text {tot }}$, while in six soils the sum of fractions was lower $\left(0.1-10.5 \mathrm{mg} \mathrm{kg}^{-1}, 0.1-10 \%\right)$ than $\mathrm{Zn}_{\text {tot }}$. The difference between $\mathrm{Zn}_{\text {tot }}$ and the sum of 
Table 7. Soil $\mathrm{Zn}$ extracted by pyrophosphate $\left(\mathrm{Zn}_{\mathrm{py}}\right)$ and oxalate $\left(\mathrm{Zn}_{\mathrm{ox}}\right)$ as well as residual $\mathrm{Zn}\left(\mathrm{Zn}_{\text {res }}\right)$, and the sum of fractions $\left(\mathrm{Zn}_{\mathrm{py}}+\mathrm{Zn}_{\mathrm{ox}}+\mathrm{Zn}_{\mathrm{res}}\right)$ and total $\mathrm{Zn}\left(\mathrm{Zn}_{\mathrm{tot}}\right)$ of 13 representative soils.

\begin{tabular}{|c|c|c|c|c|c|c|c|}
\hline \multirow[t]{2}{*}{ Soil } & & \multirow[t]{2}{*}{$\mathrm{Zn}_{\text {tot }}$} & \multirow[t]{2}{*}{$\mathrm{Zn}_{\mathrm{py}}$} & \multirow[t]{2}{*}{$\mathrm{Zn}_{\mathrm{ox}}$} & \multirow{2}{*}{$\mathrm{Zn}_{\text {res }}$} & \multicolumn{2}{|c|}{ Sum of fractions } \\
\hline & & & & & & $\mathrm{mg} \mathrm{kg}^{-1}$ & $\%^{1}$ \\
\hline 201 & Heavy clay & 137.2 & 3.1 & 2.4 & 145.3 & 150.8 & 110 \\
\hline $10^{2}$ & Gyttja clay & 109.1 & 4.2 & 2.0 & 109.3 & 115.4 & 106 \\
\hline 202 & Silty clay & 184.6 & 2.7 & 3.2 & 183.3 & 189.2 & 102 \\
\hline 206 & Very fine sand & 109.5 & 2.1 & 2.1 & 94.5 & 99.0 & 90 \\
\hline 207 & Very fine sand & 140.6 & 2.7 & 2.3 & 137.6 & 142.6 & 101 \\
\hline 208 & Very fine sand & 91.1 & 2.8 & 2.5 & 82.7 & 88.0 & 97 \\
\hline 209 & Very fine sand & 88.0 & 5.1 & 2.6 & 78.6 & 86.3 & 98 \\
\hline 210 & Silt & 151.5 & 3.9 & 3.0 & 150.6 & 157.5 & 104 \\
\hline 211 & Fine sand & 67.9 & 3.6 & 2.4 & 59.5 & 65.9 & 97 \\
\hline $73^{2}$ & Sandy moraine & 15.7 & 3.2 & 1.2 & 13.0 & 17.3 & 110 \\
\hline 212 & Mull & 88.0 & 3.6 & 1.4 & 82.9 & 87.9 & 100 \\
\hline $90^{2}$ & Carex peat & 42.2 & 12.3 & 1.5 & 33.2 & 47.0 & 111 \\
\hline $100^{2}$ & Carex peat & 34.4 & 17.5 & 1.7 & 16.3 & 35.5 & 103 \\
\hline \multicolumn{2}{|c|}{ Mean } & 96.9 & 5.1 & 2.2 & 91.3 & 98.6 & 102 \\
\hline
\end{tabular}

${ }^{1}$ Percent of $\mathrm{Zn}_{\text {tot }}$

${ }^{2}$ Soil from surface soil material (Appendix 2)

the fractions was not statistically significant $(\mathrm{t}=$ $0.897^{\text {n.s. }}$, paired t-test), showing that no major loss of the sample had occurred. The sum of the fractions correlated closely with $\mathrm{Zn}_{\text {tot }}\left(\mathrm{r}=0.99^{\text {**** }}\right)$.

\subsection{Chemical and statistical analyses}

\subsubsection{Determination of $\mathrm{Zn}$}

All the extractions and digestions were performed in duplicate and were repeated when large deviations between the replicates occurred. In filtrations, Schleicher \& Shüll $589^{3}$ (Blue ribbon) filter paper was used unless otherwise mentioned. Silicon and polythene stoppers were used in capping centrifuge glass tubes and volumetric flasks because rubber stoppers were found to be sources of soluble $\mathrm{Zn}$. The centrifugations were run for $10 \mathrm{~min}$ at $3000 \mathrm{G}$. Zinc concentrations of the $\mathrm{MgCl}_{2}$ extracts were measured by atomic absorption spectrophotometry (AAS) using the standard addition method. Zinc concentration of the other extracts was measured by AAS using standard solutions matched for the matrix of the extracts.

\section{a. Total $\mathrm{Zn}$ and chemically specific fractions of $\mathrm{Zn}$ in soil}

Total $\mathrm{Zn}$. A 500-mg soil sample was digested in a teflon crucible with $20 \mathrm{ml}$ of $\mathrm{HNO}_{3}$ until dry. Thereafter $3 \mathrm{ml}$ of $\mathrm{HClO}_{4}$ and $3 \mathrm{ml}$ of $\mathrm{H}_{2} \mathrm{SO}_{4}$ were added and warmed until fumes evolved. Heating was continued for 10 minutes. Then, $5 \mathrm{ml}$ of $\mathrm{H}_{2} \mathrm{SO}_{4}$ and $15 \mathrm{ml}$ of $\mathrm{HF}$ were added and evaporated to dryness. To remove the fluoride, $5 \mathrm{ml}$ of concentrated $\mathrm{H}_{2} \mathrm{SO}_{4}$ was added and evaporated to dryness. Finally, $20 \mathrm{ml}$ of deionized water and $10 \mathrm{ml}$ of concentrated $\mathrm{HCl}$ solution were added, and the mixture was warmed up and washed into a $100-\mathrm{ml}$ volumetric flask.

Water-soluble and exchangeable $\mathrm{Zn}$ was extracted by shaking $10 \mathrm{~g}$ of soil for 2 hours with $50 \mathrm{ml}$ of 0.5 $\mathrm{M} \mathrm{MgCl}_{2}$ in 100-ml polythene tubes in a reciprocating shaker, centrifuged and filtered.

Extraction with $0.1 \mathrm{M} \mathrm{K}_{4} \mathrm{P}_{2} \mathrm{O}_{7}$ solution ( $\mathrm{pH} \mathrm{10)}$ ) was 
performed by shaking 2.5-g samples of soil in $50 \mathrm{ml}$ of pyrophosphate solution in a reciprocating shaker in centrifuge glass tubes. After 1 hour of shaking the suspensions were allowed to stand overnight (16 hours); the following morning the suspensions were shaken for 10 more minutes, centrifuged and filtered. The sample was washed by shaking with $50 \mathrm{ml}$ of deionized water for 1 hour, and after centrifugation the solution was discarded.

Oxalate extraction was carried out sequentially after the pyrophosphate extraction. Oxalate solution $(50 \mathrm{ml}$ of $0.026 \mathrm{M}$ ammonium oxalate, 0.024 $\mathrm{M}$ oxalic acid, $\mathrm{pH}$ 2.9) was added into the centrifuge glass tubes and shaken for 4 hours in daylight, centrifuged, filtered and analyzed for $\mathrm{Zn}$.

\section{b. Procedures used in soil fertility testing}

Contrary to the fractionation of soil $\mathrm{Zn}$, determination of $\mathrm{Zn}$ in soil testing does not aim at extracting chemically specific fractions. These determinations do not involve assumptions of the bonding mechanism or soil constituent to which $\mathrm{Zn}$ is bound but attempt to obtain information on the size of $\mathrm{Zn}$ reserves available to plants. The solutions should ideally extract $\mathrm{Zn}$ from the same soil components which supply plants with $\mathrm{Zn}$, and the quantities of $\mathrm{Zn}$ extracted should correlate with $\mathrm{Zn}$ uptake by plants. Mineral acids $(\mathrm{HCl})$, neutral salts (1 M $\mathrm{MgCl}_{2}$ ) and chelating agents (EDTA, DTPA) are commonly used for the extraction of $\mathrm{Zn}$ in soil testing. In the present study, methods presented in the literature were applied, and studies on the optimization of the procedures were not carried out.

In the acid ammonium acetate procedure ( $A A A C)$, a solution containing $0.5 \mathrm{M} \mathrm{CH}_{3} \mathrm{COONH}_{4}$ and $0.5 \mathrm{M}$ $\mathrm{CH}_{3} \mathrm{COOH}$ was made of acetic acid and $\mathrm{NH}_{4} \mathrm{OH}$, and the $\mathrm{pH}$ was adjusted to 4.65 with $\mathrm{NH}_{4} \mathrm{OH}$ or acetic acid. This solution is used in soil testing in Finland to extract $\mathrm{Ca}, \mathrm{Mg}, \mathrm{K}$ and $\mathrm{P}$, and this was also used as an extractant for plant-available $\mathrm{Zn}$ by SILLANPÄÄ and LAKANEN (1966). In the present study, $20 \mathrm{ml}$ of soil was shaken with $200 \mathrm{ml}$ of the extractant in polythene bottles in a planar shaker for 1 hour, filtered and analyzed for $\mathrm{Zn}$.
In the AAAc-EDTA procedure, the soil is extracted with a solution containing $0.5 \mathrm{M} \mathrm{CH}_{3} \mathrm{COONH}_{4}$, $0.5 \mathrm{M} \mathrm{CH}_{3} \mathrm{COOH}$ and $0.02 \mathrm{M} \mathrm{Na}_{2}$-EDTA at pH 4.65 (LAKANEN and ERVIÖ 1971). Zinc, together with other metallic micronutrients, has been extracted with this solution in soil testing in Finland since 1986. In this procedure, $25-\mathrm{ml}$ samples of soil were shaken with $250 \mathrm{ml}$ of the extracting solution for 1 hour in a rotary shaker, filtered (Tesorp 04110, $130 \mathrm{~g} \mathrm{~m}^{-2}$ ) and analyzed for $\mathrm{Zn}$. Most extractions with AAAc-EDTA were performed routinely in duplicate at Viljavuuspalvelu Oy - Soil Analysis Service Ltd. Part of the extractions with AAAcEDTA were carried out at Kemira Oy Espoo Research Centre and at the Department of Applied Chemistry and Microbiology, University of Helsinki.

For the DTPA procedure, developed by LINDSAY and NORVELL (1978) and commonly used as an extractant for metallic micronutrients in soil testing, a solution containing $0.005 \mathrm{M}$ diethylenetriaminepentaacetic acid (DTPA), $0.01 \mathrm{M}$ triethanolamine (TEA) and $0.01 \mathrm{M} \mathrm{CaCl}_{2}$ at $\mathrm{pH} 7.3$ was prepared. In the extraction, $10 \mathrm{~g}$ of mineral soil or $10 \mathrm{ml}$ of organogenic soil was shaken for 2 hours in polythene bottles, filtered and analyzed for $\mathrm{Zn}$.

\section{c. Zinc in plant material}

The $\mathrm{Zn}$ content of plant material was determined at Soil Analysis Service Ltd. Plant samples were dried at $60^{\circ} \mathrm{C}$ and ground. Prior to analysis, approximately $1.0 \mathrm{~g}$ of plant material was weighed into tared glass vessels and the exact weight was recorded. The sample was dried at $105^{\circ} \mathrm{C}$ for 4 hours, cooled and weighed, and the dry matter content was calculated. Simultaneously, another sample (approximately $1.0 \mathrm{~g}$, exact weight recorded) was weighed for dry ashing. The sample was heated in a quartz crucible at $550^{\circ} \mathrm{C}$ for 4 hours until a white ash was obtained. After cooling, the ash was wetted with a few drops of deionized water, $10 \mathrm{ml}$ of $4 \mathrm{M} \mathrm{HCl}$ was added, and the crucible was heated for 30 minutes in a sand bath. The contents of the crucible were transferred quantitatively into a 100 -ml volumetric flask which was filled with water. After the 
remaining solid material had settled to the bottom, a 10-ml sample was taken and the $\mathrm{Zn}$ concentration of the solution was determined by AAS. The consistency of the results was checked by including one standard hay sample in every set of 40 samples. In 35 determinations, the mean $\mathrm{Zn}$ concentration of the standard sample was $22.5 \mathrm{mg} \mathrm{kg}^{-1}$, range 19 - 31 $\mathrm{mg} \mathrm{kg}^{-1}$, standard deviation $2.56 \mathrm{mg} \mathrm{kg}^{-1}$ and coefficient of variation $11.4 \%$. In addition, in one determination the standard gave a value of $42 \mathrm{mg} \mathrm{kg}^{-1}$, probably due to contamination at some point, resulting in repeated determinations of several samples of the set. Routinely, a duplicate determination was carried out with every eight samples.

\section{d. Zinc in fertilizers}

Fertilizer samples were dissolved with aqua regia to facilitate the determination of $\mathrm{Zn}$. A sample (1.00 g) of ground fertilizer was weighed into a $250-\mathrm{ml}$ beaker, and a few drops of water, $10 \mathrm{ml}$ of concentrated $\mathrm{HNO}_{3}$ and $30 \mathrm{ml}$ of concentrated $\mathrm{HCl}$ were added and evaporated to dryness. After cooling, 10 $\mathrm{ml}$ of concentrated $\mathrm{HCl}$ was added and evaporated to dryness. Thereafter, $50 \mathrm{ml}$ of water and $10 \mathrm{ml}$ of concentrated $\mathrm{HCl}$ were added and boiled until the precipitation was dissolved. The solution was poured into a volumetric flask, filled and filtered if necessary and analyzed for $\mathrm{Zn}$.

\subsubsection{Other analyses}

The soil organic carbon was determined by a modified wet digestion method (GRAHAM 1948). It was assumed that $80 \%$ of the carbon was oxidized in the treatment. The organic matter content was calculated by multiplying the organic $\mathrm{C}$ content by 1.724 . The particle size composition of the mineral material in the soil samples was determined by the pipette method (ELONEN 1971). The determination was made for all mineral soils (organic matter content less than 20\%) and for most mull soils (organic matter content $20-40 \%$ ). Soil pH was measured in water $(20 \mathrm{ml}$ of soil, $50 \mathrm{ml}$ of water) after 2 hours of equilibration. The bulk density of ground $(<2 \mathrm{~mm})$ soil was determined by weighing two 50-ml samples of soil.
Poorly crystalline $\mathrm{Fe}$ and $\mathrm{Al}$ oxides were extracted with $0.05 \mathrm{M}$ oxalate solution at $\mathrm{pH} 3.3$ (NISKANEN 1989). The concentrations of $\mathrm{Fe}$ and $\mathrm{Al}$ in the extracts were measured by AAS. The airacetylene flame and acetylene-nitrous oxide flame were used in the determination of $\mathrm{Fe}$ and $\mathrm{Al}$, respectively.

In order to determine the content of $\mathrm{Zn}_{\text {tot }}$ in textural fractions, clay $(<0.002 \mathrm{~mm})$ and silt plus very fine sand $(0.002-0.05 \mathrm{~mm})$ fractions were separated in three soil samples. The flocculating and cementing agents were first removed with hydrogen peroxide $\left(\mathrm{H}_{2} \mathrm{O}_{2}\right)$ and by a treatment with sodium dithionite $\left(\mathrm{Na}_{2} \mathrm{~S}_{2} \mathrm{O}_{4}\right)$ and sodium citrate using $\mathrm{NaHCO}_{3}$ as a pH buffer (pH 7.3) (OLSON and ELLIS 1982). The actual separation of the textural fractions was carried out by an automated procedure for the gravity sedimentation - decantation technique (RUTLEDGE et al. 1967) with the equipment of Texas A\&M University (College Station, Texas, USA).

The contents of $\mathrm{K}, \mathrm{NH}_{4}{ }^{+}-\mathrm{N}$ and $\mathrm{NO}_{3}{ }^{-}-\mathrm{N}$ in fertilizers were determined after dissolution of the fertilizer $(20 \mathrm{~g})$ with water $\left(1 \mathrm{dm}^{3}\right)$. The sum of $\mathrm{NH}_{4}{ }^{+}-\mathrm{N}$ and $\mathrm{NO}_{3}{ }^{-}-\mathrm{N}$ was taken as the concentration of total $\mathrm{N}$. For the determination of total $\mathrm{P}$, the fertilizer was dissolved in $\mathrm{H}_{2} \mathrm{SO}_{4}$ and $\mathrm{HNO}_{3}$. The $\mathrm{pH}$ of the fertilizers was measured in a $10 \%$ solution $(w / v)$.

The concentration of $\mathrm{N}$ in barley grains was measured by the near-infrared (NIR) technique. The vegetative parts were analyzed for $\mathrm{N}$ by the Kjeldahl method.

\subsubsection{Statistical methods}

The statistical analyses were mainly carried out according to the procedures presented by RANTA et al. (1991). The variation of the results was studied by calculating the mean deviations, $\mathrm{MD}=\Sigma\left|\mathrm{x}_{\mathrm{i}}-\mu\right| / \mathrm{N}$, or standard deviations, $s=\sqrt{\left[\Sigma\left(x_{i}-\mu\right)^{2}\right] /(n-1)}$. In assessing the variation of replicates, the mean deviations were calculated. Otherwise, standard deviations were used.

Fractiles of $10 \%\left(\mathrm{~F}_{10 \%}\right)$ and $25 \%\left(\mathrm{~F}_{25 \%}\right.$, quartiles) were formed in order to group the material in terms of various characteristics. Occasionally there 
were several equal results, all of them placed in the same fractile. Therefore the ultimate sizes of the fractiles may deviate from $\mathrm{F}_{25} \%$ and $\mathrm{F}_{10 \%}$.

Means obtained from two populations were studied with the t-test. The effect of a treatment on several soils was studied by the t-test for paired measurements. Analysis of variance was used to test statistically significant differences between several means. The significance of the differences between individual means was tested by Tukey's test (HSD, $\mathrm{P}=0.05$ ). Means marked with the same superscript do not differ at $\mathrm{P}=0.05$.

The correlation between different characteristics of a population was studied. Owing to the skewed distribution of the results of several variables, logarithmic transformations (natural logarithms, $\log _{e}$ ) of results were commonly used. In addition to the linear correlation coefficients, Spearman rank correlation coefficients were calculated. The z-transformation test was applied to test the differences between the linear correlation coefficients.
Regression analyses were carried out in order to study the dependence between variables. Statistically not significant $(\mathrm{P}=0.05)$ independent variables were excluded from the regression equation one by one and the equation was recalculated until all variables in the equation were significant. The significance of the multiple determination of the regression equations was tested by the F-test. The significance of each regression coefficient (b) was tested by the t-test. To depict the relative importance of statistically significant variables, the standard partial regression coefficients, or beta coefficients $(\beta)$, were calculated as follows (STEEL and TORRIE 1981): b' = b · $\mathrm{s}_{\mathrm{i}} / \mathrm{s}_{\mathrm{y}}$, where $\mathrm{s}_{\mathrm{i}}=$ standard deviation of an independent variable and $\mathrm{s}_{\mathrm{y}}=$ standard deviation of the dependent variable.

Statistical significance of various indices is indicated with asterisks. One asterisk $\left(^{*}\right)$ indicates significance at the $5 \%$ risk level $(\mathrm{P}=0.05)$, two asterisks $\left({ }^{* *}\right)$ at the $1 \%(\mathrm{P}=0.01)$ and three asterisks $\left({ }^{* * *}\right)$ at the $0.1 \%$ level $(\mathrm{P}=0.001)$; n.s. indicates no statistical significance $(\mathrm{P}>0.05)$.

\section{ZINC IN SOIL}

\subsection{Experimental soils}

Most laboratory studies and two pot experiments were carried out with soils of a material of 107 samples which were collected from plough layers ( $A_{p}$ horizons) of cultivated fields in different parts of Finland. The samples were collected in 1987 and 1989 to represent the distribution of soil classes of cultivated soils of Finland as reported by KURKI (1982). The samples were taken from rural areas at least $100 \mathrm{~m}$ away from roads and electric wires. Moist soil samples were air-dried at room temperature and stored in plastic bags. Part of the sample was ground to pass a 2-mm sieve and stored in a cardboard box. Mineral soils except moraines were designated according to the textural classification of JUUSELA and WÄRE (1956). Clay refers to the fraction finer than $0.002 \mathrm{~mm}$, silt to $0.002-0.02$ $\mathrm{mm}$, very fine sand to $0.02-0.06 \mathrm{~mm}$ and fine sand to $0.06-0.2 \mathrm{~mm}$. Mineral soils containing $\geq 30 \%$ of clay are called clay soils. Occasionally, other mineral soils are collectively called coarse mineral soils. Organogenic soils (organic matter content $\geq 20 \%$ ) were divided into mull and peat soils, with organic matter contents of $20-40$ and $\geq 40 \%$, respectively. The soil characteristics are presented in Appendix 2 and summarized in Table 8.

The vertical distribution of $\mathrm{Zn}$ was studied on seven soil profiles of cultivated fields (Appendix 3 ). Soil profiles were sampled according to visible horizon boundaries if present. Where the subsoil was apparently homogeneous, the samples were taken to represent $20-\mathrm{cm}$ thick layers. Also 15 pairs of samples taken from the plough layer $\left(\mathrm{A}_{\mathrm{p}}\right.$ horizon) and the respective subsoil $(30-35 \mathrm{~cm})$ (Appendix 4) were investigated. The two samples of the pair were usually of the same soil class. In one case, an organogenic soil had a fine sand subsoil and one case was the contrary. 
Table 8. Distribution of surface soil samples into soil classes, and some chemical and physical properties of the experimental soils.

\begin{tabular}{|c|c|c|c|c|c|c|c|c|c|c|c|c|c|}
\hline \multirow[t]{2}{*}{ Soil class } & \multirow[t]{2}{*}{$\mathrm{n}$} & \multicolumn{2}{|c|}{$\begin{array}{c}\text { Organic C } \\
\%\end{array}$} & \multicolumn{2}{|c|}{$\begin{array}{c}\text { Clay } \\
\%\end{array}$} & \multicolumn{2}{|c|}{$\mathrm{pH}$} & \multicolumn{2}{|c|}{$\begin{array}{c}\mathrm{Fe}_{\mathrm{ox}} \\
\mathrm{mmol} \mathrm{kg-1}\end{array}$} & \multicolumn{2}{|c|}{$\begin{array}{c}\mathrm{Al}_{\mathrm{ox}} \\
\mathrm{mmol} \mathrm{kg}\end{array}$} & \multicolumn{2}{|c|}{$\begin{array}{l}\text { Bulk density }{ }^{1} \\
\qquad \mathrm{~kg} \mathrm{dm}^{-3}\end{array}$} \\
\hline & & Mean & Range & Mean & Range & Mean & Range & Mean & Range & Mean & Range & Mean & Range \\
\hline Clay & 25 & $3.5^{\mathrm{c}}$ & $1.2-9.5$ & $51^{\mathrm{a}}$ & $32-74$ & $6.0^{\mathrm{a}}$ & $4.6-6.8$ & $99^{\mathrm{a}}$ & $55-172$ & $79^{\mathrm{ab}}$ & $47-172$ & $0.96^{\mathrm{b}}$ & $0.76-1.14$ \\
\hline $\begin{array}{l}\text { Silt, loam, } \\
\text { very fine sand }\end{array}$ & 20 & $2.5^{\mathrm{c}}$ & $0.8-5.3$ & $20^{\mathrm{b}}$ & 6-29 & $5.9^{\mathrm{a}}$ & $4.2-6.8$ & $80^{\mathrm{ab}}$ & $51-210$ & $59^{b}$ & $26-137$ & $1.00^{b}$ & $0.77-1.16$ \\
\hline Fine sand, moraine & 28 & $2.7^{\mathrm{c}}$ & $0.7-6.1$ & $6^{e}$ & $1-16$ & $6.0^{\mathrm{a}}$ & 4.9-7.4 & $51^{\mathrm{b}}$ & $10-231$ & $57^{\mathrm{b}}$ & $9-178$ & $1.15^{\mathrm{a}}$ & $0.89,1.43$ \\
\hline Mull & 14 & $18.9^{b}$ & $12.4-22.6$ & n.d. & - & $5.5^{\mathrm{ab}}$ & $4.8-6.2$ & $120^{\mathrm{a}}$ & $54-249$ & $107^{a}$ & $17-266$ & $0.65^{c}$ & $0.53-0.77$ \\
\hline Peat & 20 & $38.0^{\mathrm{a}}$ & $23.9-50.4$ & n.d. & - & $5.0^{\mathrm{b}}$ & $3.8-6.2$ & $131^{\mathrm{a}}$ & $29-252$ & $91^{\mathrm{ab}}$ & $10-249$ & $0.37 \mathrm{~d}$ & $0.25-0.55$ \\
\hline
\end{tabular}

1 Ground $(<2 \mathrm{~mm})$ soil

n.d. $=$ Not determined

\subsection{Zinc in surface soil}

\subsubsection{Total Zn}

\section{a. Soil samples}

Total $\mathrm{Zn}\left(\mathrm{Zn}_{\text {tot }}\right)$ in the surface soil samples ranged from 10 to $420 \mathrm{mg} \mathrm{kg}^{-1}$, mean $71 \mathrm{mg} \mathrm{kg}^{-1}$ (Appendix 5). In a fine sand soil (soil 71 from Harjavalta) there was a very high content of $\mathrm{Zn}_{\text {tot }}(420 \mathrm{mg}$ $\mathrm{kg}^{-1}$ ), while the bulk of the results ranged rather uniformly between the second highest $(202 \mathrm{mg}$ $\left.\mathrm{kg}^{-1}\right)$ and the lowest value $\left(10.3 \mathrm{mg} \mathrm{kg}{ }^{-1}\right)$. The ranges of $\mathrm{Zn}_{\text {tot }}$ overlapped markedly in the five soil classes (Table 9). However, the average $\mathrm{Zn}_{\text {tot }}$ in the clay soils was higher than that of silt, loam and very fine sand soils, and excluding soil 71 , the $\mathrm{Zn}_{\text {tot }}$ in fine sands and moraines was still lower. The mean $\mathrm{Zn}_{\text {tot }}$ of the two organogenic soil classes did not differ significantly from one another or from the fine sand and moraine soils but was lower than that of the more fine-textured mineral soil classes. The mean deviation of the individual measurements of a soil sample averaged $1.8 \mathrm{mg} \mathrm{kg}^{-1}$, i.e. $2.8 \%$ of the mean, range $0-17.6 \%$ of the mean. The mean deviation exceeded $5 \%$ in 18 soils which were poor in $\mathrm{Zn}_{\text {tot. }}$.

The results of $\mathrm{Zn}_{\text {tot }}$ were divided into quartiles $\left(F_{25 \%}\right)$ (Table 10). The frequency of the different
Table 9. Total $\mathrm{Zn}$ in the surface soils.

\begin{tabular}{lrrrr}
\hline Soil class & $\mathrm{n}$ & Mean & \multicolumn{1}{c}{$\mathrm{s}$} & Range \\
& & $\cdots$ & & \\
& 25 & $141.0^{\mathrm{a}}$ & 37.0 & $66.4-202$ \\
Clay & 20 & $96.4^{\mathrm{b}}$ & 34.5 & $58.0-201$ \\
Silt, loam, & & & & \\
very fine sand & 28 & $62.1^{1}$ & 73.1 & $13.4-420$ \\
Fine sand, moraine & 27 & $48.8^{\mathrm{c}}$ & 20.9 & $13.4-102$ \\
$\quad$-soil 71 excluded & 14 & $48.7^{\mathrm{c}}$ & 17.9 & $20.0-80.1$ \\
Mull & 20 & $34.7^{\mathrm{c}}$ & 20.3 & $10.3-85.6$ \\
Peat & & & &
\end{tabular}

1 Mean not included in the statistical analysis.

Table 10. Limits of quartiles $\left(\mathrm{F}_{25 \%}\right)$ of $\mathrm{Zn}_{\text {tot }}$ and number of soils from different soil classes in each quartile.

\begin{tabular}{lcccr}
\hline \multirow{2}{*}{$\begin{array}{l}\text { Soil } \\
\text { class }\end{array}$} & \multicolumn{4}{c}{$\begin{array}{c}\text { Quartile of } \mathrm{Zn}_{\text {tot }} \text { and its limits } \\
\mathrm{mg} \mathrm{kg}^{-1}\end{array}$} \\
\cline { 2 - 5 } & $\begin{array}{c}\text { I } \\
\geq 112\end{array}$ & $\begin{array}{c}\text { II } \\
109-66.8\end{array}$ & $\begin{array}{c}\text { III } \\
66.4-40.3\end{array}$ & $\begin{array}{c}\text { IV } \\
\text { S }\end{array}$ \\
\hline Clay & 19 & 5 & 1 & 0 \\
Silt, loam, & & & & \\
very fine sand & 6 & 11 & 3 & 0 \\
Fine sand, moraine & 1 & 6 & 11 & 10 \\
Mull & 0 & 4 & 6 & 4 \\
Peat & 0 & 1 & 6 & 13 \\
\hline
\end{tabular}

soil classes in each quartile demonstrates the abundance of $\mathrm{Zn}_{\text {tot }}$ in clay soils and the small re- 
serves of $\mathrm{Zn}_{\text {tot }}$ in the coarsest mineral soils and organogenic soils. As many as 19 out of 25 clay soils occurred in the largest $\mathrm{F}_{25} \%$, six out of the seven heavy clay soils (clay $>60 \%$ ) containing more than $150 \mathrm{mg} \mathrm{Zn}_{\text {tot }} \mathrm{kg}^{-1}$. The smallest $\mathrm{F}_{25 \%}$ contained 10 fine sand and moraine soils, and in these soils more than half $(57-91 \%)$ of the mineral material was coarser than $0.06 \mathrm{~mm}$ (i.e. fine sand or coarser). However, the peat soils were poorest in $\mathrm{Zn}_{\text {tot. }}$ As many as 13 out of the 20 peat soils occurred in the smallest $\mathrm{F}_{25} \%$.

When the results were transformed into milligrams per $\mathrm{dm}^{3}$ of soil, the difference between mineral and organogenic soils became greater. The average $\mathrm{Zn}_{\text {tot }}$ was 31 and $14 \mathrm{mg} \mathrm{dm}^{-3}$ in mull and peat soils, respectively, while the results of the mineral soils were not altered by the transformation. The present material consisted of 11 Carex peat soils; eight of them contained less than $10 \mathrm{mg}$ $\mathrm{Zn}_{\text {tot }} \mathrm{dm}^{-3}$ of soil. The lowest $\mathrm{Zn}_{\text {tot }}\left(3.2 \mathrm{mg} \mathrm{dm}^{-3}\right)$, occurring in a Carex peat soil of Sotkamo (97), corresponded to $6 \mathrm{~kg} \mathrm{ha}^{-1}$ in a $20 \mathrm{~cm}$ deep plough layer, while clay soils commonly contained as much as $300 \mathrm{~kg} \mathrm{Zn}_{\text {tot }} \mathrm{ha}^{-1}$.

Linear correlation coefficients were calculated between $\mathrm{Zn}_{\text {tot }}\left(\mathrm{mg} \mathrm{kg}^{-1}\right)$ and some soil characteristics (Table 11). In mineral soils, excluding soil $71, \mathrm{Zn}_{\text {tot }}$ correlated positively with clay content and negatively with the content of coarse mineral material $(>0.06 \mathrm{~mm})$. There was also a positive correlation between $\mathrm{Zn}_{\text {tot }}$ and $\mathrm{Fe}_{\mathrm{ox}}$, but the partial correlation between these two variables was not

Table 11. Linear correlation coefficients (r) between $\mathrm{Zn}_{\text {tot }}$ $\left(\mathrm{mg} \mathrm{kg}^{-1}\right)$ and some soil properties of mineral and organogenic soils.

\begin{tabular}{lcc}
\hline Soil characteristic & $\begin{array}{c}\text { Mineral soils } \\
\mathrm{n}=72\end{array}$ & $\begin{array}{c}\text { Organogenic soils } \\
\mathrm{n}=34\end{array}$ \\
\hline $\mathrm{pH}$ & $0.23^{\text {n.s. }}$ & $0.29^{\text {n.s. }}$ \\
Organic C & $0.00^{\text {n.s. }}$ & $-0.53^{* *}$ \\
$\mathrm{Fe}_{\mathrm{ox}}$ & $0.40^{* *}$ & $0.03^{\text {n.s. }}$ \\
$\mathrm{Al}_{\text {ox }}$ & $0.24^{*}$ & $0.17^{\text {n.s. }}$ \\
$\mathrm{Clay}_{\text {Silt }}$ & $0.81^{* * .}$ & - \\
$\mathrm{CF}^{1}$ & $0.38^{* *}$ & - \\
\hline
\end{tabular}

${ }^{1} \mathrm{CF}=$ Coarse mineral fractions $(>0.06 \mathrm{~mm})$.

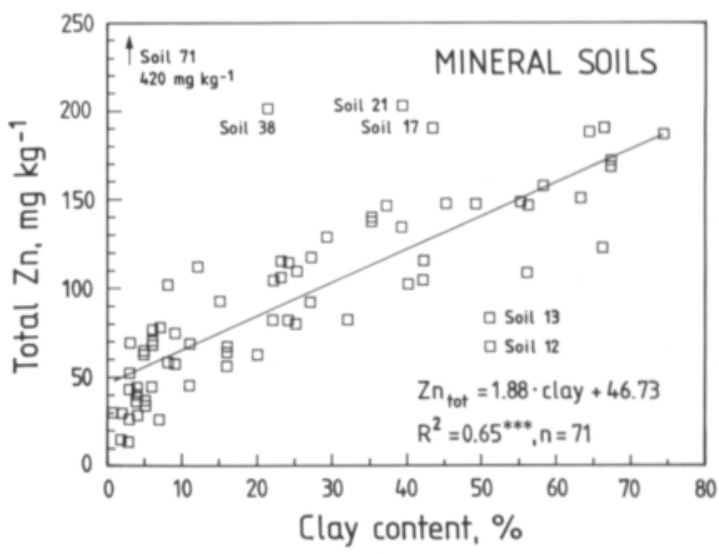

Fig. 1. Dependence of total $\mathrm{Zn}\left(\mathrm{Zn}_{\mathrm{tot}}\right)$ concentration of mineral soils on clay content.

statistically significant when the effect of clay was eliminated. The dependence of $\mathrm{Zn}_{\text {tot }}$ on clay content in mineral soils is presented in Figure 1. Some soils $(17,21,38,71)$ contained more $\mathrm{Zn}_{\text {tot }}$ than the other soils of the same clay content. Inversely, the gyttja clay 12 (Vihti) and the silty clay 13 (Perniö) contained less $\mathrm{Zn}$ than expected. In soil 12 the organic C content $(9.5 \%)$ was higher than average, resulting in a smaller quantity of mineral material and lower $\mathrm{Zn}_{\text {tot }}$ in the sample weighed for the analysis. The low $\mathrm{Zn}_{\text {tot }}$ of soil 13 may be due to the abundance of coarser materials which are usually poor in $\mathrm{Zn}_{\text {tot }}$. In soil $13,33 \%$ of the mineral material was coarser than $0.02 \mathrm{~mm}$ (very fine sand and coarser), while the average of these materials in clay soils was only $20 \%$.

In organogenic soils, there was a negative correlation between $\mathrm{Zn}_{\text {tot }}$ and organic $\mathrm{C}$. The content of mineral material is inversely reflected in the organic $\mathrm{C}$ content and the correlation between $\mathrm{Zn}_{\text {tot }}$ and organic $\mathrm{C}$ thus indicates the fact that mineral material was richer in $\mathrm{Zn}_{\text {tot }}$ than was organic matter. Figure 2 shows that all the soils which contained more than $35 \%$ organic $C$ exhibited a very low concentration of $\mathrm{Zn}_{\text {tot }}$.

The results of $\mathrm{Zn}_{\text {tot }}$ were further studied by multiple regression analyses. In mineral soils $\mathrm{Zn}_{\text {tot }}(\mathrm{mg}$ $\mathrm{kg}^{-1}$ ) increased with increasing content of clay and silt $(\%)$ and $\mathrm{Al}_{\mathrm{ox}}\left(\mathrm{mmol} \mathrm{kg}{ }^{-1}\right)$. According to the regression analysis, an increase in organic $\mathrm{C}(\mathrm{C}, \%)$ 


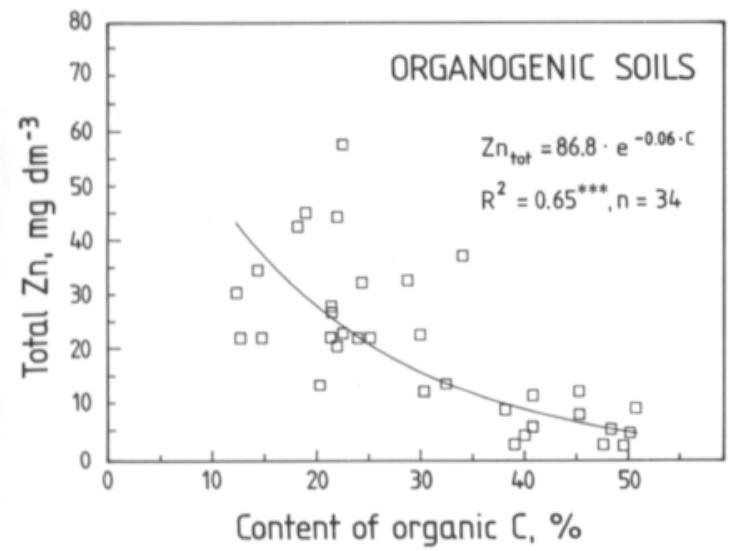

Fig. 2. Dependence of total $\mathrm{Zn}\left(\mathrm{Zn}_{\text {tot }}\right)$ concentration of organogenic soils on the organic $\mathrm{C}$ content (C).

was coincident with the decrease in $\mathrm{Zn}_{\text {tot }}$ even though there was no significant linear correlation between these two variables. The t-test of the regression coefficients and beta coefficients $(\beta)$ of the independent variables showed that clay content was by far the dominant variable (Table 12). The regression equation was as follows $(n=72)$ :

$$
\begin{aligned}
\mathrm{Zn}_{\text {tot }}= & 1.79 \text { Clay }+0.66 \text { Silt }-7.90 \mathrm{C}+0.20 \mathrm{Al}_{\mathrm{ox}} \\
& +42.14 \\
& \mathrm{R}^{2}=0.74^{* * *}
\end{aligned}
$$

In organogenic soils, the dependence of $\mathrm{Zn}_{\mathrm{tot}}$ on different soil characteristics was weaker. In no equation did the coefficient of determination $\left(\mathrm{R}^{2}\right)$ exceed 0.30 when the results were expressed as milligrams or millimoles per kilogram of soil. However, when the regression analysis was carried out with results transformed into milligrams or millimoles per $\mathrm{dm}^{3}$ of soil, a higher coefficient of multiple determination $\left(\mathrm{R}^{2}\right)$ was obtained. According to the following equation $(\mathrm{n}=34), \mathrm{Zn}_{\text {tot }}(\mathrm{mg}$ $\mathrm{dm}^{-3}$ ) decreased with increasing organic $\mathrm{C}(\%)$ while $\mathrm{Al}_{\mathrm{ox}}\left(\mathrm{mmol} \mathrm{dm}^{-3}\right)$ had a positive impact on $\mathrm{Zn}_{\text {tot }}$ :

$$
\begin{aligned}
\mathrm{Zn}_{\text {tot }}= & -0.69 \mathrm{C}+0.11 \mathrm{Al}_{\mathrm{ox}}+36.75 \\
& \mathrm{R}^{2}=0.60^{* * * *}
\end{aligned}
$$

Table 12. $t$-Values of the regression coefficients and beta coefficients $(\beta)$ of the independent variables explaining the variation of $\mathrm{Zn}_{\text {tot }}$ in mineral and organogenic soils.

\begin{tabular}{lccccr}
\hline \multirow{2}{*}{$\begin{array}{l}\text { Independent } \\
\text { variable }\end{array}$} & \multicolumn{2}{c}{ Mineral soils } & & \multicolumn{2}{c}{ Organogenic soils } \\
\cline { 2 - 3 } \cline { 6 - 7 } & $\mathrm{t}$ & $\beta$ & & $\mathrm{t}$ & $\beta$ \\
\hline Clay & $11.469^{* * *}$ & 0.77 & & - & - \\
Silt & $3.224^{* *}$ & 0.21 & & - & - \\
Organic C & $-3.576^{* * *}$ & -0.25 & & $-4.719^{* * *}$ & -0.58 \\
$\mathrm{Al}_{\text {ox }}$ & $2.056^{*}$ & 0.14 & & $2.635^{*}$ & 0.33 \\
\hline
\end{tabular}

The organic $\mathrm{C}$ content, being relatively the more important variable (Table 12), inversely reflects the abundance of mineral material in the soil, and $\mathrm{Al}_{\mathrm{ox}}$ may stand for the abundance of aluminosilicates. There was a negative correlation between organic $\mathrm{C}$ and $\mathrm{Al}_{\mathrm{ox}}\left(\mathrm{r}=0.48^{* *}\right)$, showing that the $\mathrm{Al}_{\mathrm{ox}}$ decreased with decreasing mineral material, which obviously also resulted in a decrease of $\mathrm{Zn}_{\text {tot }}$.

\section{b. Particle size fractions}

Of three silty clay soils (204 and 205 of Appendix 1; 10 of Appendix 2), clay and silt plus very fine sand were separated and analyzed for $\mathrm{Zn}_{\text {tot }}$. The textural fractions separated had probably lost at least part of the secondary $\mathrm{Zn}$ during the pretreatments with hydrogen peroxide, citrate and dithionite. Therefore, the $\mathrm{Zn}_{\text {tot }}$ of the soil fractions actually gives the quantity of $\mathrm{Zn}$ contained in primary minerals, while the results of the whole soil contained primary and secondary $\mathrm{Zn}$. The clay fraction contained more $\mathrm{Zn}_{\text {tot }}$ than did silt plus very fine

\begin{tabular}{|c|c|c|c|c|}
\hline \multirow{2}{*}{\multicolumn{2}{|c|}{ Fraction }} & \multicolumn{3}{|c|}{ Soil } \\
\hline & & 10 & 204 & 205 \\
\hline Clay & & $189.3^{\mathrm{ab}}$ & $199.5^{\mathrm{a}}$ & $178.8^{\mathrm{b}}$ \\
\hline Silt plus very fine sand & & $83.0^{\mathrm{d}}$ & $69.8^{e}$ & $60.2^{e}$ \\
\hline \multirow[t]{2}{*}{ Whole soil } & & $112.1^{\mathrm{c}}$ & $99.7^{\mathrm{c}}$ & $85.4^{\mathrm{d}}$ \\
\hline & $\mathrm{HSD}_{0.05}$ & 12.8 & & \\
\hline
\end{tabular}
sand (Table 13). In soil 205, the clay fraction was slightly poorer in $\mathrm{Zn}_{\text {tot }}$ than in soil 204 , while the

Table 13. Content of $\mathrm{Zn}_{\text {tot }}\left(\mathrm{mg} \mathrm{kg}^{-1}\right)$ in clay and silt plus very fine sand fractions and in the whole soil in three soils. ${ }^{1}$

1 All means were tested simultaneously. 
silt plus very fine sand of soil 10 was richer in $\mathrm{Zn}_{\text {tot }}$ than this fraction in the other two soils. The results of these analyses confirmed that the clay content largely determines the concentration of $\mathrm{Zn}_{\text {tot }}$ in a mineral soil but also silt and very fine sand seem to contribute substantially to $\mathrm{Zn}_{\text {tot }}$.

\subsubsection{Fractions of soil $\mathrm{Zn}$}

In the fractionation of soil $\mathrm{Zn}$, water-soluble and exchangeable $\mathrm{Zn}\left(\mathrm{Zn}_{\text {ex }}\right)$ were extracted by $\mathrm{MgCl}_{2}$. A new sample was weighed for the sequential extraction with pyrophosphate and oxalate which were assumed to dissolve $\mathrm{Zn}$ bound by organic matter $\left(\mathrm{Zn}_{\text {py }}\right)$ and sesquioxides $\left(\mathrm{Zn}_{\mathrm{ox}}\right)$, respectively. Residual $\mathrm{Zn}\left(\mathrm{Zn}_{\text {res }}\right)$ remaining in the soil after the oxalate extraction was obtained as the difference of $\mathrm{Zn}_{\text {tot }}$ and $\mathrm{Zn}_{\text {py }}+\mathrm{Zn}_{\text {ox }}$.

\section{a. Water-soluble and exchangeable $\mathrm{Zn}$}

Water-soluble and exchangeable $\mathrm{Zn}\left(\mathrm{Zn}_{\mathrm{ex}}\right)$ ranged from 0.3 to $22.0 \mathrm{mg} \mathrm{kg}^{-1}$ (Appendix 5). The mean $\mathrm{Zn}_{\text {ex }}$ (Table 14) did not differ markedly from one mineral soil class to another, but the means in the two organogenic soil classes were considerably higher than those of the mineral soil classes. When studying the results expressed as milligrams of $\mathrm{Zn}$ per $\mathrm{dm}^{3}$ of soil, the difference between the means of the five soil classes were not statistically significant.

Table 14. Water-soluble and exchangeable $\mathrm{Zn}$ in surface soils.

\begin{tabular}{lcccr}
\hline Soil class & $\mathrm{n}$ & Mean & $\begin{array}{c}\mathrm{s} \\
\text { (ng kge }\end{array}$ & \multicolumn{1}{c}{ Range } \\
\hline Clay & 25 & $1.7^{\mathrm{b}}$ & 1.2 & $0.5-4.9$ \\
Silt, loam, & 20 & $1.3^{\mathrm{b}}$ & 0.8 & $0.5-3.5$ \\
very fine sand & & & & \\
Fine sand, moraine & 28 & $2.5^{1}$ & 4.3 & $0.3-22.0$ \\
$\quad$ - soil 71 excluded & 27 & $1.8^{\mathrm{b}}$ & 1.9 & $0.3-8.3$ \\
Mull & 14 & $2.6^{\mathrm{b}}$ & 2.0 & $0.9-7.0$ \\
Peat & 20 & $5.2^{\mathrm{a}}$ & 2.9 & $1.1-11.0$ \\
\hline
\end{tabular}

${ }^{1}$ Mean not included in the statistical analysis.

\section{b. Zinc bound by organic matter and sesquioxides}

In 106 soils, $\mathrm{Zn}$ extracted with pyrophosphate $\left(\mathrm{Zn}_{\text {py }}\right)$ ranged from 1.4 to $53.8 \mathrm{mg} \mathrm{kg}^{-1}$. In addition, in soil 71 rich in $\mathrm{Zn}_{\text {tot }}$ there was also plenty of $\mathrm{Zn}_{\text {py }}$ (227 mg kg ${ }^{-1}$ ) (Appendix 5). The mean $\mathrm{Zn}_{\text {py }}$ was higher in peat soils than in the other four soil classes (Table 15). However, after transforming the results to milligrams per $\mathrm{dm}^{3}$ of soil, statistical differences between the soil classes were nonexistent with means of 4.9 and $5.3 \mathrm{mg} \mathrm{dm}^{-3}$ in the mull and peat soils, respectively.

Soil $\mathrm{Zn}$ extracted by oxalate $\left(\mathrm{Zn}_{\mathrm{ox}}\right)$ sequentially after the pyrophosphate treatment ranged in 106 soils from 0.5 to $13.0 \mathrm{mg} \mathrm{kg}^{-1}$, while soil 71 contained $115 \mathrm{mg} \mathrm{Zn}_{\text {ox }} \mathrm{kg}^{-1}$ (Appendix 5). The mean $\mathrm{Zn}_{\text {ox }}$ (Table 15) was higher in clay soils than in fine sand and moraine soils or in organogenic soils. When expressing the results as milligrams of $\mathrm{Zn}$ per $\mathrm{dm}^{3}$ of soil, the organogenic soil classes were by far poorer in $\mathrm{Zn}_{\text {ox }}$ than were the mineral soils with means of 1.2 and $0.9 \mathrm{mg} \mathrm{dm}^{-3}$ in mull and peat soils, respectively. In nine out of the 25 clay soils, $\mathrm{Zn}_{\text {ox }}$ was higher than $\mathrm{Zn}_{\text {py }}$. In soils other than clay, $\mathrm{Zn}_{\text {ox }}$ was lower than $\mathrm{Zn}_{\text {py }}$ with only two exceptions; in organogenic soils $\mathrm{Zn}_{\text {py }}$ was four to five times higher than $\mathrm{Zn}_{\text {ox }}$.

The average mean deviation of the replicates of $\mathrm{Zn}_{\text {py }}$ was $0.33 \mathrm{mg} \mathrm{kg}^{-1}$, or $5.5 \%$ of the mean and ranged from 0 to $18.9 \%$ of the mean in the 107 surface soils. The mean deviation of $\mathrm{Zn}_{\mathrm{ox}}$ averaged $0.16 \mathrm{mg} \mathrm{kg}^{-1}$, or $4.8 \%$ of the mean, ranging from 0 to $25.2 \%$. The mean deviation exceeded $10 \%$ in 15 and eight soils in the determination of $\mathrm{Zn}_{\text {py }}$ and $\mathrm{Zn}_{\text {ox }}$, respectively.

The lowest results of $\mathrm{Zn}_{\text {py }}\left(\mathrm{F}_{11 \%}\right.$ ) were distributed over all mineral soil classes, while those of $\mathrm{Zn}_{\text {ox }}\left(\mathrm{F}_{10 \%}\right)$ occurred in fine sand and moraine soils (eight soils) as well as in organogenic soils (three soils). There was no soil in common to the smallest $\mathrm{F}_{11 \%}$ of $\mathrm{Zn}_{\text {py }}$ and the smallest $\mathrm{F}_{10 \%}$ of $\mathrm{Zn}_{\text {ox }}$. The mineral soils poorest in $\mathrm{Zn}_{\text {ox }}$ were characterized by a coarse texture and low $\mathrm{Fe}_{\mathrm{ox}}$ content. In the eight fine sand and moraine soils of the smallest $F_{10 \%}$ of $\mathrm{Zn}_{\mathrm{ox}}$ the average concentration of $\mathrm{Fe}_{\mathrm{ox}}$ was 22.0 mmol kg${ }^{-1}$ which was less $\left(\mathrm{t}=3.598^{* * *}\right)$ than in the rest of the fine sand and moraine soils (mean 62.3 
Table 15 . Soil $\mathrm{Zn}$ extracted sequentially by pyrophosphate $\left(\mathrm{Zn}_{\mathrm{py}}\right)$ and oxalate $\left(\mathrm{Zn}_{\mathrm{ox}}\right)$ as well as residual $\mathrm{Zn}(\mathrm{Zn}$ res $) \cdot{ }^{1}$

\begin{tabular}{|c|c|c|c|c|c|c|c|}
\hline \multirow[t]{2}{*}{ Soil class } & \multirow[t]{2}{*}{$\mathrm{n}$} & \multicolumn{2}{|c|}{$\mathrm{Zn}_{\mathrm{py}}, \mathrm{mg} \mathrm{kg}^{-1}$} & \multicolumn{2}{|c|}{$\mathrm{Zn}_{\mathrm{ox}}, \mathrm{mg} \mathrm{kg}^{-1}$} & \multicolumn{2}{|c|}{$\mathrm{Zn}_{\text {res }}, \mathrm{mg} \mathrm{kg}^{-1}$} \\
\hline & & Mean & Range & Mean & Range & Mean & Range \\
\hline Clay & 25 & $4.9^{b}$ & $1.4-23.1$ & $3.5^{\mathrm{a}}$ & $1.2-13.0$ & $132.0^{\mathrm{a}}$ & $62.6-193$ \\
\hline $\begin{array}{l}\text { Silt, loam, very } \\
\text { fine sand }\end{array}$ & 20 & $3.4^{\mathrm{b}}$ & $1.4-6.7$ & $2.5^{\mathrm{ab}}$ & $1.4-5.0$ & $90.5^{\mathrm{b}}$ & $54.2-192$ \\
\hline Fine sand, moraine & 28 & $12.7^{2}$ & $1.4-227$ & $6.1^{2}$ & $0.6-115$ & $43.3^{2}$ & $10.2-96.9$ \\
\hline -soil 71 excluded & 27 & $4.8^{\mathrm{b}}$ & $1.4-23.9$ & $2.0^{\mathrm{b}}$ & $0.6-8.8$ & $42.0^{c}$ & $10.2-96.9$ \\
\hline Mull & 14 & $7.8^{b}$ & $1.6-26.9$ & $1.8^{\mathrm{b}}$ & $1.0-3.5$ & $39.1^{\text {cd }}$ & $15.7-69.8$ \\
\hline Peat & 20 & $14.1^{\mathrm{a}}$ & $2.2-53.8$ & $2.4^{\mathrm{ab}}$ & $0.5-10.3$ & $18.7^{\mathrm{d}}$ & $3.9-53.0$ \\
\hline
\end{tabular}

1 Results were tested separately for $\mathrm{Zn}_{\mathrm{py}}$ and $\mathrm{Zn}_{\mathrm{ox}}$.

${ }^{2}$ Mean not included in the statistical analysis.

Table 16. Complexed $\mathrm{Zn}$ calculated as the difference between $\mathrm{Zn}_{p y}$ and $\mathrm{Zn}_{e x}$ (i.e. $\mathrm{Zn}_{p y}-\mathrm{Zn}_{e x}$ ).

\begin{tabular}{lcrrrr}
\hline Soil class & $\mathrm{n}$ & Mean & $\mathrm{s}$ & Range & $\begin{array}{c}\left(\mathrm{Zn}_{\mathrm{py}}-\mathrm{Zn}_{\mathrm{ex}}\right) / \mathrm{Zn}_{\mathrm{py}} \\
\%\end{array}$ \\
\hline Clay & 25 & $3.1^{\mathrm{b}}$ & 3.4 & $0.5-18.2$ & $43-84$ \\
Silt, loam, very fine sand & 20 & $2.2^{\mathrm{b}}$ & 1.6 & $0.6-4.8$ & $16-85$ \\
Fine sand, moraine & 28 & $10.2^{\mathrm{b}}$ & 38.3 & $0.6-205$ & $22-90$ \\
- soil 71 excluded & 27 & $3.0^{\mathrm{b}}$ & 3.5 & $0.6-18.7$ & $22-85$ \\
Mull & 14 & $5.1^{\mathrm{ab}}$ & 4.8 & $0.3-6.1$ & $19-78$ \\
Peat & 20 & $8.9^{\mathrm{a}}$ & 9.8 & $0.7-43.0$ & $19-80$ \\
\hline
\end{tabular}

Mean not included in the statistical analysis.

$\left.\mathrm{mmol} \mathrm{kg}^{-1}, \mathrm{n}=20\right)$. The highest results $\left(\mathrm{F}_{10 \%}\right)$ of $\mathrm{Zn}_{\text {py }}$ occurred with three exceptions in organogenic soils, while those of $\mathrm{Zn}_{\text {ox }}\left(\mathrm{F}_{10 \%}\right)$ were the most common in clay soils.

\section{c. Complexed Zn}

Water-soluble and exchangeable $\mathrm{Zn}$ extracted with $\mathrm{MgCl}_{2}$ was probably included also in $\mathrm{Zn}$ extracted by pyrophosphate $\left(\mathrm{Zn}_{\mathrm{py}}\right)$. Therefore the results of the pyrophosphate extraction can be divided into two parts: (1) water-soluble and exchangeable $\mathrm{Zn}$ bound by non-specific electrostatic forces and (2) $\mathrm{Zn}$ presumably bound mainly by organic matter in complexed forms by covalent forces. The quantities of complexed $\mathrm{Zn}$ were calculated as the difference of $Z_{n}$ py and $Z_{n}$ ex (i.e. $Z_{\text {py }}-Z_{n_{\text {ex }}}$ ) (Table 16). This fraction was larger in peat soils than in the mineral soil classes but, again, there were no differences between the soil classes when the results were expressed as milligrams of $\mathrm{Zn}$ per $\mathrm{dm}^{3}$.

The percentage of $\mathrm{Zn}_{\text {py }}$ which was bound by covalent forces, i.e. the ratio $100 \cdot\left(Z_{n}\right.$ py $\left.-Z_{\text {ex }}\right) / Z n_{p y}$, ranged $14-90 \%$ (Table 16) and correlated with soil $\mathrm{pH}\left(\mathrm{r}=0.65^{* * *}\right)$. The fractile $\left(\mathrm{F}_{10 \%}\right)$ of the smallest percentage (14-38\%) of $\mathrm{Zn}_{\text {py }}$ in complexed forms consisted of six organogenic soils $(\mathrm{pH} 3.8$ - 5.6) and of five coarse mineral soils ( $\mathrm{pH} 4.2$ - 5.8). The four fine sand and moraine soils of this group had only a moderate acidity ( $\mathrm{pH} 4.9-5.8$ ) and a very low content of clay $(\leq 4 \%)$ as well as $\mathrm{Fe}_{\mathrm{ox}}$ and $\mathrm{Al}_{\text {ox }}$. Three of these soils $(72,73,74)$ were those of the coarsest texture in the whole soil material. For comparison, the most acid clay soils $(10,20,26)$ had nearly the same $\mathrm{pH}(4.6,5.2,5.0$, respectively) but a higher percentage $(52-62 \%)$ of $\mathrm{Zn}_{\text {py }}$ was not water soluble or exchangeable, indicating a difference in bonding of $\mathrm{Zn}$ in acid clay soils and acid fine sands. 


\section{d. Residual $\mathrm{Zn}$}

Residual $\mathrm{Zn}$ ( $\mathrm{Zn}_{\text {res }}$ ) (Table 15 ) represents the fraction bound in the mineral lattices. This fraction was the largest in clay soils and decreased in mineral soils with decreasing clay content; 11 soils richest in clay were also in the largest $\mathrm{F}_{25 \%}$ of $\mathrm{Zn}_{\text {res. }}$. The lowest results occurred in organogenic soils; 15 out of 20 peat soils, especially those of the highest organic $\mathrm{C}$ content, and five out of 14 mull soils were in the smallest $\mathrm{F}_{25 \%}$ of $\mathrm{Zn}_{\text {res. }}$. The smallest $\mathrm{F}_{25 \%}$ also contained seven fine sand and moraine soils which were very coarse in texture, containing only $1-7 \%$ clay and 3 - $13 \%$ silt. The $\mathrm{pH}$ of these seven soils (4.9 - 6.3, mean 5.5) was lower $\left(\mathrm{t}=3.295^{* *}\right)$ than in the rest of the fine sand and moraine soils (mean 6.2). When the results of $\mathrm{Zn}_{\text {res }}$ were transformed into milligrams per $\mathrm{dm}^{3}$ of soil, the difference between organogenic and mineral soils became greater with means of 25.4 and $8.0 \mathrm{mg} \mathrm{dm}^{-3}$ for mull and peat soils, respectively, while the transformation did not have a marked influence on the results of mineral soils.

\section{e. Relationship between $\mathrm{Zn}$ fractions and other soil properties}

Owing to the skewed distribution of the results of secondary $\mathrm{Zn}$ fractions $\left(\mathrm{Zn}_{\mathrm{ex}}, \mathrm{Zn}_{\text {py }}, \mathrm{Zn}_{\text {py }}-\mathrm{Zn}_{\text {ex }}\right.$ and $\mathrm{Zn}_{\mathrm{ox}}$ ), the linear correlation coefficients were calculated using the natural logarithms $\left(\log _{\mathrm{e}}\right)$ of the results (Table 17). In order to eliminate the effect of the skewness of the material, also the Spearman rank correlation coefficients were calculated between the various $\mathrm{Zn}$ fractions and soil properties. The two correlation coefficients were similar and only the linear ones are presented. Soil 71, extremely rich in $\mathrm{Zn}$, was not included in the calculations.

In mineral and organogenic soils, $\mathrm{Zn}_{\mathrm{ex}}$ correlated negatively with soil $\mathrm{pH}$. The correlation was made weaker by a few soils which in spite of a $\mathrm{pH}$ above 6.5 contained plenty of $\mathrm{Zn}_{\mathrm{ex}}$. $\mathrm{Zn}_{\mathrm{ex}}$ correlated closely with $\mathrm{Zn}_{\text {py }}$, but it should be taken into account that $\mathrm{Zn}_{\text {ex }}$ is actually a part of $\mathrm{Zn}_{\text {py }}$; the correlation between $\mathrm{Zn}_{\text {ex }}$ and complexed $\mathrm{Zn}\left(\mathrm{Zn}_{\text {py }}-\mathrm{Zn}_{\mathrm{ex}}\right)$ remained lower than that between $\mathrm{Zn}_{\mathrm{ex}}$ and $\mathrm{Zn}_{\text {py }}$. Organic $\mathrm{C}$ content seemed to correlate with $\mathrm{Zn}_{\mathrm{ex}}$, reflecting the lower

Table 17. Linear correlation coefficients between $\mathrm{Zn}$ fractions and some other soil properties. Tabulations were carried out using natural logarithms of concentrations of $\mathrm{Zn}, \mathrm{Fe}$ and $\mathrm{Al}$, expressed as $\mathrm{mg} \mathrm{kg}^{-1}(\mathrm{Zn})$ or mmol kg-1 $(\mathrm{Fe}, \mathrm{Al})$.

\begin{tabular}{|c|c|c|c|c|c|}
\hline & $\mathrm{Zn}_{\mathrm{ex}}$ & $\mathrm{Zn}_{\mathrm{py}}-\mathrm{Zn}_{\mathrm{ex}}$ & $\mathrm{Zn}_{\mathrm{py}}$ & $\mathrm{Zn}_{\text {ox }}$ & $\mathrm{Zn}_{\text {res }}$ \\
\hline \multicolumn{6}{|c|}{ Mineral soils $(n=72)$ : } \\
\hline Clay & $0.05^{\text {n.s. }}$ & $0.07^{\text {n.s. }}$ & $0.03^{\text {n.s. }}$ & $0.47^{\cdots}$ & $0.76^{* * *}$ \\
\hline Organic C & $0.30^{* *}$ & $0.10^{\text {n.s. }}$ & $0.23^{\text {n.s. }}$ & $-0.13^{\text {n.s. }}$ & $-0.04^{\text {n.s. }}$ \\
\hline $\mathrm{pH}$ & $-0.70^{\cdots} \cdots$ & $0.11^{\text {n.s. }}$ & $-0.29^{*}$ & $0.28^{*}$ & $0.23^{\text {n.s. }}$ \\
\hline $\mathrm{Fe}_{\text {ox }}$ & $0.09^{\text {n.s. }}$ & $0.07^{\text {n.s. }}$ & $0.12^{\text {n.s. }}$ & $0.57^{\cdots *}$ & $0.64^{* * *}$ \\
\hline $\mathrm{Al}_{\text {ox }}$ & $0.03^{\text {n.s. }}$ & $0.26^{*}$ & $0.14^{\mathrm{n} . \mathrm{s}}$ & $0.26^{*}$ & $0.38^{* *}$ \\
\hline $\mathrm{Zn}_{\text {tot }}$ & $-0.02^{\text {n.s. }}$ & $0.23^{\text {n.s. }}$ & $0.12^{\text {n.s. }}$ & $0.76^{* *}$ & $0.99^{* *}$ \\
\hline $\mathrm{Zn}_{\text {res }}$ & $-0.10^{n . s .}$ & $0.16^{\text {n.s. }}$ & $0.04^{\text {n.s. }}$ & $0.69^{* *}$ & \\
\hline $\mathrm{Zn}_{\mathrm{ox}}$ & $0.22^{\text {n.s. }}$ & $0.61^{\cdots *}$ & $0.53^{\cdots *}$ & & \\
\hline $\mathrm{Zn}_{\mathrm{py}}$ & $0.78^{* \cdots}$ & $0.87^{\cdots *}$ & & & \\
\hline $\mathrm{Zn}_{\mathrm{py}}-\mathrm{Zn}_{\mathrm{ex}}$ & $0.40^{* *}$ & & & & \\
\hline \multicolumn{6}{|c|}{ Organogenic soils $(n=34)$ : } \\
\hline Organic C & $0.48^{* *}$ & $0.22^{\text {n.s. }}$ & $0.34^{*}$ & $0.11^{\mathrm{ns.s}}$ & $-0.80^{* *}$ \\
\hline $\mathrm{pH}$ & $-0.54 \cdots$ & $0.07^{\text {n.s. }}$ & $-0.14^{\text {n.s. }}$ & $0.04^{\text {n.s. }}$ & $0.39^{\circ}$ \\
\hline $\mathrm{Fe}_{o x}$ & $0.02^{\text {n.s. }}$ & $0.11^{\mathrm{ns.s}}$ & $0.08^{\text {n.s. }}$ & $0.03^{\text {n.s. }}$ & $0.22^{\text {n.s. }}$ \\
\hline $\mathrm{Al}_{\mathrm{ox}}$ & $-0.20^{\text {n.s. }}$ & $-0.34^{\text {n.s. }}$ & $-0.33^{\circ}$ & $-0.15^{\text {n.s. }}$ & $0.33^{\text {n.s. }}$ \\
\hline $\mathrm{Zn}_{\text {tot }}$ & $0.13^{\text {n.s. }}$ & $0.36^{*}$ & $0.33^{\mathrm{nss} .}$ & $0.48^{* *}$ & $0.79^{\cdots}$ \\
\hline $\mathrm{Zn}_{\text {res }}$ & $-0.28^{\text {n.s. }}$ & $-0.07^{\text {n.s. }}$ & $-0.15^{\mathrm{n.s} .}$ & $-0.05^{\text {n.s. }}$ & \\
\hline $\mathrm{Zn}_{\mathrm{ox}}$ & $0.50^{*}$ & $0.68^{* \cdots}$ & $0.69^{\cdots}$ & & \\
\hline $\mathrm{Zn}_{\mathrm{py}}$ & $0.85^{\cdots} \cdots$ & $0.95^{* *}$ & & & \\
\hline $\mathrm{Zn}_{\mathrm{py}}-\mathrm{Zn}_{\mathrm{ex}}$ & $0.65^{* *}$ & & & & \\
\hline
\end{tabular}


$\mathrm{pH}$ in soils rich in organic $\mathrm{C}\left(\mathrm{r}=-0.45^{* * *}\right.$ and $-0.44^{* *}$ in mineral and organogenic soils, respectively). Soils rich in $\mathrm{Zn}_{\text {py }}$ tended also to be rich in $\mathrm{Zn}_{\text {ox }} . \mathrm{Zn}_{\text {ox }}$ and $\mathrm{Zn}_{\text {res }}$ correlated closely with $\mathrm{Zn}_{\text {tot }}$ in mineral soils but more weakly $\left(\mathrm{z}=2.219^{*}\right.$ and $12.642^{* * *}$ for $\mathrm{Zn}_{\text {ox }}$ and $\mathrm{Zn}_{\text {res }}$, respectively) in organogenic soils. In mineral soils $\mathrm{Zn}_{\text {ox }}$ correlated with clay, $\mathrm{Fe}_{\mathrm{ox}}$ and $\mathrm{Zn}_{\text {res. }}$. Contrary to mineral soils, $\mathrm{Zn}_{\text {ox }}$ did not correlate with $\mathrm{Zn}_{\text {res }}$ or Fe $\mathrm{Fe}_{\text {ox }}$ in organogenic soils but there was a significant negative correlation between $\mathrm{Zn}_{\text {res }}$ and organic $\mathrm{C}$.

The relationships between $\mathrm{Zn}_{\mathrm{ex}}$ and other fractions of secondary $\mathrm{Zn}$ were further studied by regression analyses using the natural logarithms of $\mathrm{Zn}$ concentrations. Both in mineral and organogenic soils $\mathrm{Zn}_{\mathrm{ex}}\left(\mathrm{mg} \mathrm{kg}^{-1}\right)$ increased with increasing $\mathrm{Zn}_{\text {py }}\left(\mathrm{mg} \mathrm{kg}^{-1}\right)$ and/or decreasing soil $\mathrm{pH}$. Even though there was a statistically significant linear correlation between $\mathrm{Zn}_{\mathrm{ex}}$ and $\mathrm{Zn}_{\mathrm{ox}}$ in organogenic soils, $\mathrm{Zn}_{\text {ox }}$ remained insignificant in the regression analysis, owing to the positive correlation between $\mathrm{Zn}_{\mathrm{ox}}$ and $\mathrm{Zn}_{\text {py. }}$. The $\mathrm{t}$-values and the beta coefficients (Table 18) show that $\mathrm{pH}$ and $\mathrm{Zn}_{\text {py }}$ were relatively of equal importance in explaining the variation of $\mathrm{Zn}_{\mathrm{ex}}$. The regression equations were as follows:

$$
\begin{aligned}
& \text { Mineral soils }(\mathrm{n}=72) \text { : } \\
& \begin{aligned}
\log _{\mathrm{e}} \mathrm{Zn}_{\mathrm{ex}}= & -0.66 \mathrm{pH}+0.73 \log _{\mathrm{e}} \mathrm{Zn}_{\mathrm{py}}+3.21 \\
& \mathrm{R}^{2}=0.85^{* * *}
\end{aligned}
\end{aligned}
$$

Organogenic soils $(\mathrm{n}=34)$ :

$$
\begin{aligned}
\log _{\mathrm{e}} \mathrm{Zn}_{\mathrm{ex}}= & -0.54 \mathrm{pH}+0.66 \log _{\mathrm{e}} \mathrm{Zn}_{\mathrm{py}}+1.13 \\
& \mathrm{R}^{2}=0.84^{* * *}
\end{aligned}
$$

Dependence of $\mathrm{Zn}_{\text {py }}, \mathrm{Zn}_{\text {py }}-\mathrm{Zn}_{\mathrm{ex}}$ and $\mathrm{Zn}_{\mathrm{ox}}$ on soil characteristics was studied by regression analyses. The regression equations consisting of $\mathrm{Zn}_{\text {tot }}$, organic $\mathrm{C}, \mathrm{pH}, \mathrm{Fe}_{\mathrm{ox}}, \mathrm{Al}_{\mathrm{ox}}$ and in mineral soils clay content explained less than $10 \%$ of the variation of $\mathrm{Zn}_{\text {py }}$ and $\mathrm{Zn}_{\text {py }}-\mathrm{Zn}_{\text {ex }}$. Instead, a considerable part of the variation of $\mathrm{Zn}_{\text {ox }}\left(\mathrm{mg} \mathrm{dm}^{-3}\right)$ was explained by $\mathrm{Zn}_{\text {tot }}\left(\mathrm{mg} \mathrm{dm}^{-3}\right)(\mathrm{n}=106)$ :

$$
\begin{aligned}
\log _{\mathrm{e}} \mathrm{Zn}_{\mathrm{xx}}= & 0.65 \log _{\mathrm{e}} \mathrm{Zn}_{\text {tot }}-2.00 \\
& \mathrm{R}^{2}=0.71^{* * *}
\end{aligned}
$$

\section{f. Distribution of soil $\mathrm{Zn}$ into different fractions}

The distribution of soil $\mathrm{Zn}$ into different fractions, expressed as percentages of $\mathrm{Zn}_{\text {tot }}$, was studied (Table 19). In clay and silt soils the residual fraction $\left(\mathrm{Zn}_{\text {res }}\right)$ commonly accounted for more than $90 \%$ of $\mathrm{Zn}_{\text {tot. }}$. The distribution of $\mathrm{Zn}$ in the mineral soil classes did not differ significantly from one class to another even though in a few coarse mineral soils a larger part of $\mathrm{Zn}$ was in the secondary fractions

\begin{tabular}{|c|c|c|c|c|c|c|c|c|}
\hline \multirow[t]{2}{*}{ Soil class } & \multicolumn{2}{|c|}{$\mathrm{Zn}_{e x}$} & \multicolumn{2}{|c|}{$\mathrm{Zn}_{p y}-\mathrm{Zn}_{e x}$} & \multicolumn{2}{|c|}{$\mathrm{Zn}_{\mathrm{ox}}$} & \multicolumn{2}{|c|}{$\mathrm{Zn}_{\text {res }}$} \\
\hline & Mean & Range & Mean & Range & Mean & Range & Mean & Range \\
\hline Clay & $1.3^{\mathrm{b}}$ & $0.3-3.6$ & $2.2^{\mathrm{c}}$ & $0.5-9.6$ & $2.5^{b}$ & $1.4-6.8$ & $94.0^{\mathrm{a}}$ & $81.0-97.2$ \\
\hline Silt, loam, very fine sand & $1.5^{b}$ & $0.3-5.5$ & $2.3^{\mathrm{bc}}$ & $0.6-4.9$ & $2.6^{\mathrm{b}}$ & $1.5-4.3$ & $93.6^{\mathrm{a}}$ & $87.6-97.3$ \\
\hline Fine sand, moraine & $4.7^{2}$ & $0.4-27.0$ & $7.5^{2}$ & $1.4-48.8$ & $4.8^{2}$ & $2.0-27.4$ & $83.0^{2}$ & $18.6-95.2$ \\
\hline -soil 71 excluded & $4.8^{\mathrm{b}}$ & $0.4-27.0$ & $6.0^{\mathrm{bc}}$ & $1.4-23.9$ & $4.1^{\mathrm{b}}$ & $2.0-11.3$ & $85.1^{\text {ab }}$ & $50.5-95.2$ \\
\hline Mull & $5.7^{\mathrm{b}}$ & $2.2-17.9$ & $10.4^{b}$ & $0.7-26.3$ & $3.9^{b}$ & $1.9-7.1$ & $80.0^{\mathrm{b}}$ & $59.7-94.0$ \\
\hline Peat & $17.7^{\mathrm{a}}$ & $2.6-37.4$ & $25.1^{\mathrm{a}}$ & $2.5-54.5$ & $8.0^{\mathrm{a}}$ & $2.8-12.0$ & $49.2^{c}$ & $12.2-84.0$ \\
\hline
\end{tabular}

Table 18. $t$-Values of the regression coefficients and beta coefficients $(\beta)$ of the independent variables explaining the variation of $\log \mathrm{Zn}_{e x}$ in mineral and organogenic soils.

\begin{tabular}{lccrrr}
\hline \multirow{2}{*}{$\begin{array}{l}\text { Independent } \\
\text { variable }\end{array}$} & \multicolumn{2}{c}{ Mineral soils } & & \multicolumn{2}{c}{ Organogenic soils } \\
\cline { 2 - 3 } \cline { 6 - 7 } & $\mathrm{t}$ & \multicolumn{1}{c}{$\beta$} & & $\mathrm{t}$ & $\beta$ \\
\hline $\mathrm{pH}$ & $-10.550^{* *}$ & -0.52 & & $-6.826 * *$ & -0.51 \\
$\log \mathrm{Zn}_{\mathrm{py}}$ & $12.822^{* *}$ & 0.63 & & $8.995^{* *}$ & 0.67 \\
\hline
\end{tabular}

Table 19. Distribution of soil $\mathrm{Zn}(\%)$ into different fractions expressed as percentages of $\mathrm{Zn}_{\mathrm{tot}} \cdot{ }^{1}$

' Each fraction was tested separately.

${ }^{2}$ Mean not included in the statistical analysis. 
$\left(\mathrm{Zn}_{\text {ex }}, \mathrm{Zn}_{\text {py }}-\mathrm{Zn}_{\mathrm{ex}}, \mathrm{Zn}_{\text {ox }}\right)$ than in the rest of the mineral soils. In mull soils the percentage of $\mathrm{Zn}_{\text {res }}$ was significantly smaller than in the two most finetextured mineral soil classes. In peat soils the percentages of the secondary fractions were substantially greater and $\mathrm{Zn}_{\text {res }}$ smaller than in the other soil classes. In the 13 soils richest in organic C (34 $50 \%$ ) the sum $\mathrm{Zn}_{\text {py }}+\mathrm{Zn}_{\text {ox }}$ corresponded to as much as $68-88 \%$ of $\mathrm{Zn}_{\text {tot }}$. In mineral soils, the ratio $\left(\mathrm{Zn}_{\text {py }}+\mathrm{Zn}_{\text {ox }}\right) / \mathrm{Zn}_{\text {tot }}$ which reflects the relative abundance of secondary fractions did not correlate with soil properties, but in organogenic soils there was a close correlation between this ratio and organic $\mathrm{C}\left(\mathrm{r}=0.81^{* * *}\right)$.

Fractions of $\mathrm{Zn}$ were studied separately in mineral and organogenic soils in which $\mathrm{Zn}_{\text {py }}$ exceeded $10 \mathrm{mg} \mathrm{kg}^{-1}$ (mineral soils) or $20 \mathrm{mg} \mathrm{kg}^{-1}$ (organogenic soils) (Table 20). In these soils, the secondary $\mathrm{Zn}$ fractions ranged from $19 \%$ in clay soil 17 to $88 \%$ in peat soil 102 and were relatively larger than those in the respective soil class on average. Inquiries concerning the farming operations revealed that large quantities of farm-yard manure had been spread to the fields from where soils 53, 70, 85 and 95 originated (V. Haataja, P. Luoma and J. Nieminen 1991, Kemira Oy, I. Kallioniemi 1991, Suomen Säästöpankki, Pori, pers. commun.). It is likely that the abundance of secondary $\mathrm{Zn}$ also in soil 17 can be attributed to the use of farm-yard manure, because the respective field was located at Viikki 0.2 $\mathrm{km}$ from the barn of the farm of the University of Helsinki. Soil 71 of Harjavalta had been taken about $2 \mathrm{~km}$ from the smelter of Outokumpu Oy. No slag or farm-yard manure had been transported to the field for several years (I. Kallioniemi 1991, Suomen Säästöpankki, Pori, pers. commun.), sug-

Table 20. Soil $\mathrm{Zn}_{\mathrm{py}}$ and $\mathrm{Zn}_{\mathrm{ox}}$ as well as the ratio (\%) between secondary and $\mathrm{Zn}_{\text {tot }}$, i.e. $100 \cdot\left(\mathrm{Zn}_{\mathrm{py}}+\mathrm{Zn}_{\mathrm{ox}}\right) / \mathrm{Zn}_{\mathrm{tot}}$, in soils exceptionally rich in $\mathrm{Zn}_{\mathrm{py}}$.

\begin{tabular}{lccc}
\hline Soil & $\begin{array}{c}\mathrm{Zn}_{\mathrm{py}} \\
\mathrm{mg} \mathrm{kg}{ }^{-1}\end{array}$ & $\begin{array}{c}\mathrm{Zn}_{\text {ox }} \\
\mathrm{mg} \mathrm{kg}^{-1}\end{array}$ & $\left(\begin{array}{c}\left(\mathrm{Zn}_{\mathrm{py}}+\mathrm{Zn}_{\mathrm{ox}}\right) / \mathrm{Zn}_{\text {tot }} \\
\%\end{array}\right.$ \\
\hline $17,53,70,74$ & 18.3 & 7.1 & 36 \\
71 & 227 & 115 & 81 \\
$85,95,101,102$ & 33.8 & 5.0 & 70 \\
\hline
\end{tabular}

gesting that the abundance of $\mathrm{Zn}$ was airborne. Information of the farming of soils 74, 101 and 102 was not available.

\subsubsection{Zinc extracted by AAAc-EDTA}

In soil testing in Finland plant-available $\mathrm{Zn}$ is extracted by AAAc-EDTA at $\mathrm{pH}$ 4.65. Therefore, this method was applied also to the present surface soil material, and relationships between $\mathrm{Zn}$ extracted by AAAc-EDTA $\left(\mathrm{Zn}_{\mathrm{Ac}}\right)$ and chemically more specific fractions of soil $\mathrm{Zn}$ were investigated. Soil $\mathrm{Zn}_{\mathrm{Ac}}$ ranged from 0.6 to $165 \mathrm{mg} \mathrm{dm}^{-3}$ (Appendix 5). The highest result occurred for the same fine sand soil (71) which was rich in $\mathrm{Zn}$ according to all indices determined. The second highest result was $29.9 \mathrm{mg}$ $\mathrm{dm}^{-3}$ and the median of the whole material was 2.9 $\mathrm{mg} \mathrm{dm}{ }^{-3}$. The means of $\mathrm{Zn}_{\mathrm{Ac}}$ did not differ statistically significantly from one soil class to another (Table 21). The mean deviation of the replicates averaged $0.25 \mathrm{mg} \mathrm{dm}^{-3}$, or $4.4 \%$ of the mean, range $0-20.8 \%$. Soil 71 excluded, the mean deviation averaged $0.15 \mathrm{mg} \mathrm{dm}^{-3}$. $\mathrm{Zn}_{\mathrm{Ac}}$ corresponded on average to $45 \%$ (range $18-76 \%$ ) and $75 \%$ (range 43 - 200\%) of the sum $\mathrm{Zn}_{\text {py }}+\mathrm{Zn}_{\text {ox }}\left(\mathrm{mg} \mathrm{dm}^{-3}\right)$ in mineral and organogenic soils, respectively.

The 15 soils $\left(\mathrm{F}_{14 \%}\right)$ poorest in $\mathrm{Zn}_{\mathrm{Ac}}(\leq 1.5 \mathrm{mg}$ $\mathrm{dm}^{-3}$ ) consisted of two clay soils, 10 coarse mineral soils and three organogenic soils. The $\mathrm{pH}$ of the 12 mineral soils of this group was $5.4-6.9$, and in nine of these soils, the $\mathrm{pH}$ was above or equal to 6.0 , which was the mean $\mathrm{pH}$ for mineral soils. There

Table 21. Soil $\mathrm{Zn}$ extracted by AAAc-EDTA from surface soils.

\begin{tabular}{|c|c|c|c|c|}
\hline \multirow[t]{2}{*}{ Soil class } & \multirow[t]{2}{*}{$\mathrm{n}$} & Mean & s & Range \\
\hline & & \multicolumn{3}{|c|}{$\mathrm{mg} \mathrm{dm}^{-3}$} \\
\hline Clay & 25 & 3.7 & 3.2 & $1.1-18.0$ \\
\hline $\begin{array}{l}\text { Silt, loam, very } \\
\text { fine sand }\end{array}$ & 20 & 2.6 & 1.5 & $0.8-5.7$ \\
\hline Fine sand, moraine & 28 & 9.9 & 30.9 & $0.9-165$ \\
\hline -soil 71 excluded & 27 & 4.1 & 5.8 & $0.9-29.9$ \\
\hline Mull & 14 & 4.0 & 3.2 & $0.8-14.0$ \\
\hline Peat & 20 & 4.6 & 4.0 & $0.6-19.4$ \\
\hline
\end{tabular}


was thus a slight tendency of the soils poor in $\mathrm{Zn}_{\mathrm{Ac}}$ to have a $\mathrm{pH}$ higher than average. There were, however, several soils of high $\mathrm{pH}$ which contained plenty of $\mathrm{Zn}_{\mathrm{Ac}}$.

Linear correlation coefficients were calculated between $\mathrm{Zn}_{\mathrm{Ac}}$ and other indices of soil $\mathrm{Zn}$ using the natural logarithms of the results $\left(\mathrm{mg} \mathrm{dm}^{-3}\right)$. The $\mathrm{Zn}_{\text {Ac }}$ correlated most closely with $\mathrm{Zn}_{\text {py }}\left(\mathrm{r}=0.87^{* * *}\right.$ and $0.95^{* * *}$ in mineral and organogenic soils, respectively). The correlation was statistically highly significant also with $\mathrm{Zn}_{\mathrm{ex}}\left(\mathrm{r}=0.76^{* * *}\right.$ and $\left.0.79^{* * * *}\right)$ and $\mathrm{Zn}_{\text {ox }}\left(\mathrm{r}=0.61^{* * *}\right.$ and $\left.0.60^{* * *}\right)$. In the organogenic soils there was a significant correlation also between $\mathrm{Zn}_{\mathrm{Ac}}$ and $\mathrm{Zn}_{\text {tot }}\left(\mathrm{r}=0.42^{*}\right)$. Like $\mathrm{Zn}_{\text {py }}$, $\mathrm{Zn}_{\mathrm{Ac}}$ did not correlate with soil $\mathrm{pH}$ or with the content of clay or organic matter. Despite the highly significant correlation of $\mathrm{Zn}_{\mathrm{Ac}}$ both with $\mathrm{Zn}_{\text {py }}$ and $\mathrm{Zn}_{\text {ox }}, \mathrm{Zn}_{\text {py }}\left(\mathrm{mg} \mathrm{dm}^{-3}\right)$ alone explained statistically significantly the variation of $\mathrm{Zn}_{\mathrm{Ac}}$ (mg $\mathrm{dm}^{-3}$ ) in the regression analysis, and $\mathrm{Zn}_{\mathrm{ox}}$ was not a significant variable. The equation was as follows $(\mathrm{n}=106)$ :

$$
\begin{aligned}
& \log _{\mathrm{e}} \mathrm{Zn} \mathrm{n}_{\mathrm{Ac}}= 0.89 \log _{\mathrm{e}} \mathrm{Zn}_{\mathrm{py}}-0.090 \\
& \mathrm{R}^{2}=0.80^{* * * *}
\end{aligned}
$$

When the regression analyses were tabulated separately for mineral and organogenic soils, slightly different equations were obtained for the two soil groups. In organogenic soils, $\mathrm{Zn}_{\text {py }}$ alone explained $89 \%$ of the variation of $\mathrm{Zn}_{\mathrm{Ac}}$ (equation not shown); other soil characteristics were not significant. In the equation for mineral soils $(n=72)$, the contents $(\%)$ of clay and organic $\mathrm{C}$ were also significant variables, while $\mathrm{Zn}_{\text {py }}\left(\mathrm{mg} \mathrm{dm}^{-3}\right)$ was relatively the most important:

$$
\begin{aligned}
\log _{\mathrm{e}} \mathrm{Zn}_{\mathrm{Ac}}= & 0.91 \log _{\mathrm{e}} \mathrm{Zn}_{\mathrm{py}}+0.0064 \text { Clay } \\
& -0.049 \mathrm{C}-0.19 \\
& \mathrm{R}^{2}=0.81^{* * *}
\end{aligned}
$$

$\begin{array}{lcc} & \mathrm{t} & \beta \\ \log _{\mathrm{e}} \mathrm{Zn}_{\text {py }} & 16.642^{* * *} & 0.89 \\ \text { Clay } & 3.860^{* * *} & 0.21 \\ \text { Organic C } & -2.106^{*} & -0.12\end{array}$

The above equation shows that at a given level of
$\mathrm{Zn}_{\text {py }}$, increasing clay content enhanced the extraction power of AAAc-EDTA. The negative regression coefficient of $\mathrm{C}$ suggests that, at a given $\mathrm{Zn}_{\text {py }}$ level, increasing organic $\mathrm{C}$ reduced the extraction power of AAAc-EDTA in relation to that of pyrophosphate.

Also the relationships between $\mathrm{Zn}_{\mathrm{Ac}}\left(\mathrm{mg} \mathrm{dm}^{-3}\right)$ and $\mathrm{Zn}_{\mathrm{ex}}\left(\mathrm{mg} \mathrm{dm}^{-3}\right)$ were studied by multiple regression analyses. According to the beta coefficients ( $\beta$ ) (Table 22), $\mathrm{Zn}_{\text {ex }}$ was relatively the most important variable explaining the variation of $\mathrm{Zn}_{\mathrm{Ac}}$ both in mineral and organogenic soils. The equation below shows that the relative efficiency of AAAcEDTA to extract $\mathrm{Zn}$ increased with increasing soil $\mathrm{pH}$. In mineral soils, also the clay content increased the efficiency of AAAc-EDTA as an extractant for soil $\mathrm{Zn}$ as compared to $\mathrm{MgCl}_{2}$. The equations were as follows:

$$
\begin{aligned}
\text { Mineral soils }(\mathrm{n}=72) & \\
\log _{\mathrm{e}} \mathrm{Zn}_{\mathrm{Ac}}= & 0.98 \log _{\mathrm{e}} \mathrm{Zn}_{\mathrm{ex}}+0.62 \mathrm{pH} \\
& +0.0041 \text { Clay }-3.03 \\
& \mathrm{R}^{2}=0.78^{* * *}
\end{aligned}
$$

Organogenic soils $(\mathrm{n}=34)$ :

$$
\begin{aligned}
\log _{\mathrm{e}} \mathrm{Zn} \mathrm{n}_{\mathrm{Ac}}= & 1.05 \log _{\mathrm{e}} \mathrm{Zn}_{\mathrm{ex}}+0.48 \mathrm{pH}-1.69 \\
& \mathrm{R}^{2}=0.76^{* * *}
\end{aligned}
$$

Table 22. $t$-Values of the regression coefficients and beta coefficients $(\beta)$ of the independent variables explaining the variation of $\log \mathrm{Zn}_{\mathrm{Ac}}$ in mineral and organogenic soils.

\begin{tabular}{lccccc}
\hline $\begin{array}{l}\text { Independent } \\
\text { variable }\end{array}$ & \multicolumn{2}{c}{ Mineral soils } & & \multicolumn{2}{c}{ Organogenic soils } \\
\cline { 2 - 3 } \cline { 6 - 7 } & $\mathrm{t}$ & $\beta$ & & $\mathrm{t}$ & $\beta$ \\
\hline $\log \mathrm{Zn}_{e x}$ & $15.235^{\cdots} \cdots$ & 1.11 & & $9.779^{\cdots} \cdots$ & 0.93 \\
$\mathrm{pH}$ & $7.586^{\cdots}$ & 0.56 & & $4.149^{\cdots}$ & 0.39 \\
Clay & $2.402^{\circ}$ & 0.14 & & - & - \\
\hline
\end{tabular}

\subsection{Vertical distribution of soil $\mathrm{Zn}$}

Plant roots penetrate far below the plough layer and therefore $\mathrm{Zn}$ reserves also deeper in the soil may be important in providing the plant with $\mathrm{Zn}$. Therefore, the vertical distribution of $\mathrm{Zn}$ was studied by 
Table 23. Total $\mathrm{Zn}\left(\mathrm{Zn}_{\mathrm{tot}}\right)$ and $\mathrm{Zn}$ extracted by AAAc-EDTA $\left(\mathrm{Zn}_{\mathrm{Ac}}\right)$ in samples taken from various depths in seven soil profiles.'

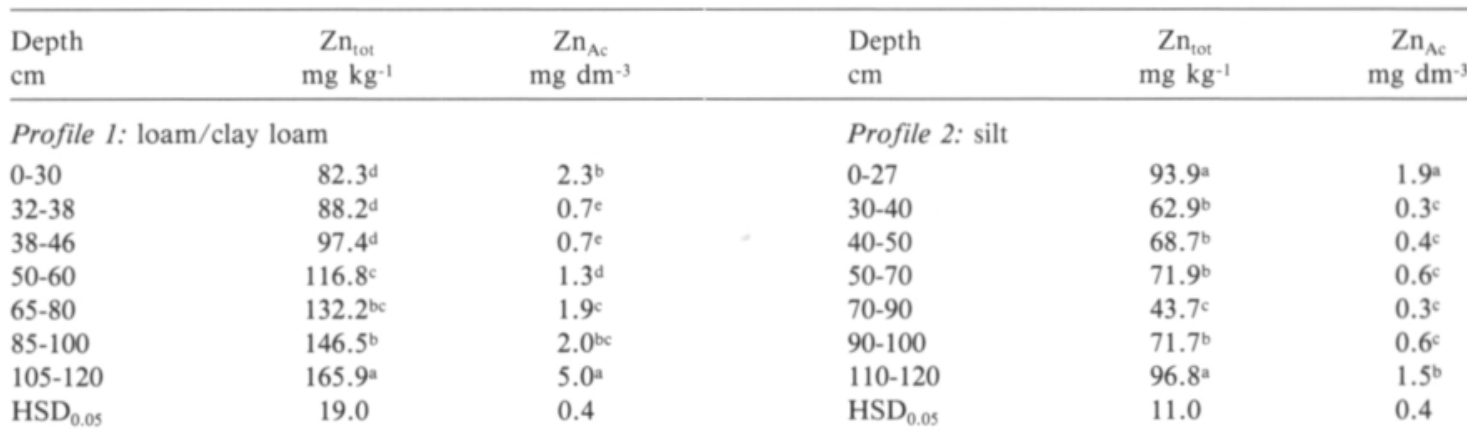

Profile 3: silty clay/heavy clay

$\begin{array}{lcl}0-30 & 129.0^{\mathrm{d}} & 4.3^{\mathrm{a}} \\ 30-40 & 129.1^{\mathrm{d}} & 2.4^{\mathrm{c}} \\ 40-60 & 137.6^{\mathrm{c}} & 1.2^{\mathrm{d}} \\ 60-80 & 159.0^{\mathrm{b}} & 3.3^{\mathrm{b}} \\ 80-100 & 191.9^{\mathrm{a}} & 3.5^{\mathrm{b}} \\ 100-120 & 192.6^{\mathrm{a}} & 3.8^{\mathrm{ab}} \\ \mathrm{HSD}_{0.05} & 6.3 & 0.7\end{array}$

Profile 4: fine sand

$\begin{array}{lcl}0-30 & 22.6^{\mathrm{b}} & 6.7^{\mathrm{a}} \\ 30-40 & 9.2^{\mathrm{e}} & 0.8^{\mathrm{b}} \\ 40-45 & 11.7^{\text {de }} & 0.7^{\mathrm{b}} \\ 45-60 & 13.7^{\mathrm{cde}} & 0.3^{\mathrm{bc}} \\ 60-80 & 17.3^{\text {bed }} & 0.2^{\mathrm{c}} \\ 80-110 & 20.1^{\mathrm{bc}} & 0.2^{\mathrm{c}} \\ 110-120 & 30.5^{\mathrm{a}} & 0.2^{\mathrm{c}} \\ \mathrm{HSD}_{0.05} & 7.2^{2} & 0.5^{\circ}\end{array}$

Profile 5: Carex peat

Profile 6: Carex peat/mud/heavy clay

$\begin{array}{lrrrrr}0-20 & 42.3^{\mathrm{a}} & 0.9^{\mathrm{a}} & 0-25 & 65.2^{\mathrm{c}} & 2.7^{\mathrm{b}} \\ 20-30 & 6.1^{\mathrm{c}} & 0.6^{\mathrm{a}} & 30-40 & 41.8^{\mathrm{a}} & 1.6^{\mathrm{c}} \\ 30-40 & 6.6^{\mathrm{c}} & 0.9^{\mathrm{a}} & 40-45 & 90.3^{\mathrm{b}} & 3^{\mathrm{a}} \\ 40-60 & 5.0^{\mathrm{c}} & 0.4^{\mathrm{a}} & 50-70 & 191.8^{\mathrm{a}} & 2.4^{\mathrm{a}} \\ 60-80 & 8.3^{\mathrm{c}} & 0.5^{\mathrm{a}} & 70-80 & 199.4^{\mathrm{a}} & 2.7^{\mathrm{b}} \\ 80-100 & 9.9^{\mathrm{c}} & 0.5^{\mathrm{a}} & \text { HSD }_{0.05} & 23.4 & 0.7^{\mathrm{a}} \\ 100-120 & 343^{\mathrm{b}} & 1.0^{\mathrm{a}} & & & \\ 120-130 & 29.6^{\mathrm{b}} & 1.1^{\mathrm{a}} & & & \\ \text { HSD }_{0.05} & 5.2 & 0.7 & & & \end{array}$

Profile 7: Carex peat/fine sand

$\begin{array}{lrl}0-30 & 13.0^{\mathrm{a}} & 6.7^{\mathrm{a}} \\ 30-50 & 6.4^{\mathrm{b}} & 1.7^{\mathrm{b}} \\ 50-70 & 2.4^{\mathrm{b}} & 1.5^{\mathrm{b}} \\ 70-90 & 2.9^{\mathrm{b}} & 0.7^{\mathrm{b}} \\ 90-110 & 3.5^{\mathrm{b}} & 0.8^{\mathrm{b}} \\ 110-125 & 14.3^{\mathrm{a}} & 0.8^{\mathrm{b}} \\ \mathrm{HSD}_{0.05} & 5.9 & 1.8\end{array}$

1 Each profile was tested separately for $\mathrm{Zn}_{\text {tot }}$ and $\mathrm{Zn}_{\mathrm{Ac}}$.

investigating soil profiles as well as sample pairs consisting of a sample from the plough layer and the subsoil.

\subsubsection{Total Zn}

The seven profiles differed greatly in the content of total $\mathrm{Zn}\left(\mathrm{Zn}_{\text {tot }}\right)$ (Table 23). In profiles P1, P3 and
P6, where the entire profile or a part of it consisted of clay soil, the peak $\mathrm{Zn}_{\text {tot }}$ exceeded $150 \mathrm{mg} \mathrm{kg}^{-1}$. In turn, in profile $\mathrm{P} 4$ dominated by fine sand as well as in the Carex peat profiles P5 and P7, all layers contained less than $50 \mathrm{mg} \mathrm{Zn}_{\text {tot kg }}{ }^{-1}$, most layers even less than $10 \mathrm{mg} \mathrm{kg}^{-1}$. The $\mathrm{Zn}_{\text {tot }}$ of organogenic layers was dependent on the $\mathrm{Zn}_{\text {tot }}$ of the mineral subsoil. This was demonstrated in profile $\mathrm{P} 7$ which had a Carex peat topsoil very poor in $\mathrm{Zn}_{\text {tot }}$ and a 
fine sand subsoil which also was poor in $\mathrm{Zn}_{\text {tot }}$. On the contrary, in profile P6 the soil below the organogenic surface horizons was heavy clay rich in $\mathrm{Zn}_{\text {tot }}$, and also the surface horizons were richer in $\mathrm{Zn}_{\text {tot }}$ as compared with the other two organogenic soil profiles.

The content of $\mathrm{Zn}_{\text {tot }}$ showed marked changes in relation to the depth within each soil profile. The highest $\mathrm{Zn}_{\text {tot }}$ occurred either in the plough layer or in the deepest horizon sampled. The lowest $\mathrm{Zn}_{\text {tot }}$ occurred between these horizons, with the exception of profile P1 (silty clay) and P3 (silt) where it was in the two or three uppermost horizons sampled. In the other five profiles (P2, P4, P5, P6, P7) $\mathrm{Zn}_{\text {tot }}$ was markedly higher in the plough layer than in the next layer below. In all profiles but one (P5) was the content of $\mathrm{Zn}_{\text {tot }}$ in the bottom of the profile at least as high as that in the plough layer. Mineral soil had obviously been mixed in the plough layer of Carex peat profile P5, increasing the $\mathrm{Zn}_{\text {tot }}$ in the plough layer of this profile. An evidence of the external source of the mineral matter was the presence of clay $(9 \%)$. Moreover, the uppermost layer contained only $9 \%$ organic $\mathrm{C}$, while in the layer below there was as much as $52 \%$ of organic $\mathrm{C}$.

The $\mathrm{Zn}_{\text {tot }}$ of the mineral soil profiles P1, P2 and P3 correlated closely with the clay content ( $r=$ $\left.0.89^{* *}-0.99^{* * *}\right)$; in profile $\mathrm{P} 4, \mathrm{Zn}_{\text {tot }}$ correlated $(\mathrm{r}=$ $\left.0.81^{*}\right)$ with very fine sand which was the finest textural fraction present in abundance. In the organogenic profiles $\mathrm{P} 5$ and $\mathrm{P} 7, \mathrm{Zn}_{\text {tot }}$ correlated negatively with organic $\mathrm{C}, \mathrm{r}=-0.92^{* *}$ and $\mathrm{r}=$ $-0.77^{\text {n.s. }}$, respectively.

\subsubsection{Zinc extracted by AAAc-EDTA}

Within a soil profile, the sampled layers differed markedly from one another in terms of $\mathrm{Zn}$ extracted by AAAc-EDTA ( $\mathrm{Zn}_{\text {Ac }}$, Table 23). In all profiles except P5 and P6 was the content of $\mathrm{Zn}_{\mathrm{Ac}}$ higher in the plough layer than in the next few underlying ones. In the Carex peat profile P5, all the horizons were equally poor in $\mathrm{Zn}_{\mathrm{Ac}}$. In profile $\mathrm{P} 6$, consisting of an organogenic surface horizon and a heavy clay subsoil, the maximum $\mathrm{Zn}_{\mathrm{Ac}}$ was measured in the upper part of the mineral subsoil which is the former soil surface currently covered by organic materials. In the three mineral soil profiles (P1, P2 and P3) dominated by clay or silt there was a tendency that deeper in the soil profile $\mathrm{Zn}_{\mathrm{Ac}}$ first decreased, increasing again in the deepest horizons. In profile $\mathrm{P} 1, \mathrm{Zn}_{\mathrm{Ac}}$ was highest in the deepest layer sampled. On the contrary, in the coarse mineral soil profile ( $\mathrm{P} 4)$ and in the two Carex peat profiles there was no increase of $\mathrm{Zn}_{\mathrm{Ac}}$ in the deeper layers.

In 14 out of the 15 plough layer and subsoil sample pairs, the subsoil was poorer in $\mathrm{Zn}_{\mathrm{Ac}}$ than was the respective plough layer (Table 24, details in Appendix 4). According to the t-test for paired measurements, the difference in $\mathrm{Zn}_{\mathrm{Ac}}$ between the plough layer and subsoil was highly significant $(\mathrm{t}=$ $4.804^{* * *}, \mathrm{n}=15$ ). The only exception was the sample pair from Forssa which consisted of a mull plough layer and a subsoil of heavy clay which was richer in $\mathrm{Zn}_{\mathrm{Ac}}$. In the other sample pairs, $\mathrm{Zn}_{\mathrm{Ac}}$ in the subsoil averaged $39 \%$ of that in the plough layer. Only in heavy clay subsoils did $\mathrm{Zn}_{\mathrm{Ac}}$ exceed $2.0 \mathrm{mg} \mathrm{dm}^{-3}$.

Table 24. Soil $\mathrm{Zn}$ extracted by AAAc-EDTA $\left(\mathrm{Zn}_{\mathrm{Ac}}\right)$ from the plough layer and subsoil samples.

\begin{tabular}{llll}
\hline Soil class & \multirow{2}{*}{$\mathrm{n}$} & \multicolumn{2}{c}{$\mathrm{Zn}_{\mathrm{Ac}}, \mathrm{mg} \mathrm{dm}^{-3}$} \\
\cline { 3 - 4 } & & Plough layer & Subsoil \\
\hline Clay soils & 6 & 4.4 & 2.0 \\
Coarse mineral soils & 4 & 2.4 & 0.7 \\
Organogenic soils & 5 & $3.0(3.0)^{2}$ & $1.2(0.6)^{2}$ \\
\hline
\end{tabular}

Soil class of the plough layer.

${ }^{2}$ Results of the sample pair of Forssa not included.

\subsection{Extractability of $\mathrm{Zn}$ added to soil}

The ability of common extractants to dissolve $\mathrm{Zn}$ from soil was studied on four surface soils $(18,34$, $78,104)$. Deionized water or $\mathrm{ZnSO}_{4}$ solution was added to weighed portions of air-dry soil (three replicates, $200 \mathrm{ml}$ each), and the samples were incubated at an approximate field capacity for two weeks after which the samples were air-dried and ground with a porcelain mortar and a pestle. The soil samples of the first incubation ( $\mathrm{Zn}$ addition 
$9.06 \mathrm{mg} \mathrm{dm}^{-3}$ ) were extracted (two replicates) with the following solutions:

\section{1. $0.5 \mathrm{M} \mathrm{MgCl}_{2}$}

2. $0.5 \mathrm{M}$ ammonium acetate $-0.5 \mathrm{M}$ acetic acid at $\mathrm{pH} 4.65$ (AAAc)

3. $0.5 \mathrm{M}$ ammonium acetate $-0.5 \mathrm{M}$ acetic acid - $0.02 \mathrm{M} \mathrm{Na}$-EDTA at pH 4.65 (AAAcEDTA)

4. DTPA - TEA - $\mathrm{CaCl}_{2}$ at $\mathrm{pH} 7.3$ (DTPA)

The unbuffered $\mathrm{MgCl}_{2}$ solution extracted exchangeable $\mathrm{Zn}\left(\mathrm{Zn}_{\mathrm{ex}}\right)$ at soil $\mathrm{pH}$, AAAc at a constant $\mathrm{pH}$ of 4.65 . The results of AAAc-EDTA demonstrate the effect of the addition of a chelating agent. The use of DTPA allows comparison to be made with an extractant containing the other widely used chelating agent.

The primary purpose of the second incubation experiment ( $\mathrm{Zn}$ addition $9.26 \mathrm{mg} \mathrm{dm}^{-3}$ ) was to study the extractability of added $\mathrm{Zn}$ in sequential extraction by $0.1 \mathrm{M} \mathrm{K}_{4} \mathrm{P}_{2} \mathrm{O}_{7}$ and $0.05 \mathrm{M}$ oxalate. In both experiments, the results of extractions for which the samples were weighed $\left(\mathrm{MgCl}_{2}, \mathrm{DTPA}\right.$, pyrophosphate and oxalate) were transformed to milligrams per $\mathrm{dm}^{3}$ of soil by multiplying the results by the bulk density determined for the incubated soil samples.
As far as native $\mathrm{Zn}$ is concerned, $\mathrm{MgCl}_{2}$ was the weakest extractant in clay (18) which was the least acid ( $\mathrm{pH}$ 6.2) of the four soils, while in the three more acid soils $\mathrm{MgCl}_{2}$ and AAAc extracted equal quantities of native $\mathrm{Zn}$ (Table 25). In the clay soil, the higher efficiency of AAAc was probably due to its $\mathrm{pH}$ (4.65) which is 1.5 units below the soil $\mathrm{pH}$. The acidity may have caused dissolution of $\mathrm{Zn}$ reserves which would not be exchangeable at native soil $\mathrm{pH}$. From the other three soils AAAc probably extracted only the exchangeable $\mathrm{Zn}$ fraction.

Addition of EDTA to the AAAc solution markedly enhanced the extraction of native $\mathrm{Zn}$. In clay (18) and organogenic soils $(78,104)$ the quantities dissolved were at least tripled, and in the highly acid loam (34) they increased by $50 \%$. DTPA was a weaker extractant than AAAc-EDTA in the three soils except the peat (104) where DTPA and AAAc-EDTA extracted native $\mathrm{Zn}$ with an equal efficiency. The sequence of efficiency in mineral soils was thus:

\section{$\mathrm{MgCl}_{2} \leq \mathrm{AAAc}=\mathrm{DTPA}<\mathrm{AAAc}-\mathrm{EDTA}$}

In organogenic soils the sequence was as follows:

$$
\mathrm{MgCl}_{2}=\text { AAAc }<\text { DTPA } \leq \text { AAAc-EDTA }
$$

Table 25. Soil $\mathrm{Zn}\left(\mathrm{mg} \mathrm{dm}^{-3}\right)$ extracted by $\mathrm{MgCl}_{2}\left(\mathrm{Zn}_{\mathrm{ex}}\right)$, AAAc $\left(\mathrm{Zn}_{\mathrm{AAAc}}\right)$, AAAc-EDTA $\left(\mathrm{Zn}_{\mathrm{Ac}}\right)$ and DTPA $\left(\mathrm{Zn}_{\text {DTPA }}\right)$ from soil samples incubated with or without added $\mathrm{Zn}$. The percentage of added $\mathrm{Zn}$ which was extracted appears in parentheses. $\mathrm{Zn}+=\mathrm{Zn}$ added $\left(9.06 \mathrm{mg} \mathrm{dm}^{-3}\right.$ of soil), $\mathrm{Zn}-=$ native $\mathrm{Zn} .^{1}$

\begin{tabular}{|c|c|c|c|c|c|c|}
\hline Soil & & $\mathrm{Zn}_{\mathrm{ex}}$ & $\mathrm{Zn}_{\mathrm{AAAc}}$ & $\mathrm{Zn}_{\mathrm{Ac}}$ & $\mathrm{Zn}_{\mathrm{DTPA}}$ & $\mathrm{HSD}_{0.05}$ \\
\hline \multirow[t]{3}{*}{18} & $\mathrm{Zn}+$ & $1.42^{\mathrm{d}}$ & $3.74^{c}$ & $9.40^{\mathrm{a}}$ & $5.82^{\mathrm{b}}$ & 0.47 \\
\hline & $\mathrm{Zn}-$ & $0.29^{c}$ & $0.68^{b}$ & $2.07^{\mathrm{a}}$ & $0.91^{\mathrm{b}}$ & 0.35 \\
\hline & Difference & $1.13(12 \%)$ & $3.06(34 \%)$ & $7.33(81 \%)$ & $4.91(54 \%)$ & \\
\hline \multirow[t]{3}{*}{34} & $\mathrm{Zn}+$ & $7.26^{\mathrm{c}}$ & $8.37^{b}$ & $10.65^{\mathrm{a}}$ & $8.04^{\mathrm{bc}}$ & 0.97 \\
\hline & $\mathrm{Zn}$ - & $1.90^{\mathrm{b}}$ & $1.99^{b}$ & $2.95^{a}$ & $1.93^{\mathrm{b}}$ & 0.29 \\
\hline & Difference & $5.36(59 \%)$ & $6.38(70 \%)$ & $7.70(85 \%)$ & $6.11(67 \%)$ & \\
\hline \multirow[t]{3}{*}{78} & $\mathrm{Zn}+$ & $4.04^{c}$ & $4.65^{c}$ & $11.75^{\mathrm{a}}$ & $8.29^{b}$ & 1.06 \\
\hline & $\mathrm{Zn}-$ & $0.94^{\mathrm{c}}$ & $1.08^{\mathrm{c}}$ & $3.46^{\mathrm{a}}$ & $1.79^{\mathrm{b}}$ & 0.48 \\
\hline & Difference & $3.10(34 \%)$ & $3.57(39 \%)$ & $8.29(92 \%)$ & $6.50(72 \%)$ & \\
\hline \multirow[t]{3}{*}{104} & $\mathrm{Zn}+$ & $4.76^{b}$ & $4.18^{b}$ & $10.66^{\mathrm{a}}$ & $10.42^{\mathrm{a}}$ & 0.83 \\
\hline & $\mathrm{Zn}-$ & $1.00^{\mathrm{b}}$ & $0.95^{b}$ & $3.34^{\mathrm{a}}$ & $3.70^{a}$ & 0.54 \\
\hline & Difference & $3.76(42 \%)$ & $3.24(36 \%)$ & $7.32(81 \%)$ & $6.72(74 \%)$ & \\
\hline
\end{tabular}

I In each soil, the results of the samples incubated with and without added $\mathrm{Zn}$ were tested separately for each extraction. 
Table 26. Soil $\mathrm{Zn}\left(\mathrm{mg} \mathrm{dm}^{-3}\right)$ extracted by pyrophosphate $\left(\mathrm{Zn}_{\mathrm{py}}\right)$ and oxalate $\left(\mathrm{Zn}_{\mathrm{ox}}\right)$ from samples incubated with or without added $\mathrm{Zn}$. The percentages of added $\mathrm{Zn}$ which was extracted appear in parentheses. $\mathrm{Zn}+=\mathrm{Zn}$ added $\left(9.26 \mathrm{mg} \mathrm{dm}^{-3}\right.$ of soil), $\mathrm{Zn}-=$ native $\mathrm{Zn} \cdot{ }^{1}$

\begin{tabular}{clllll}
\hline Soil & & $\mathrm{Zn}_{\mathrm{py}}$ & $\mathrm{Zn}_{\text {ox }}$ & Sum & HSD $_{0.05}$ \\
\hline 18 & $\mathrm{Zn}+$ & $9.16^{\mathrm{a}}$ & $4.34^{\mathrm{b}}$ & & 0.69 \\
& $\mathrm{Zn}-$ & $1.39^{\mathrm{b}}$ & $2.50^{\mathrm{a}}$ & & 0.23 \\
& Difference & $7.77(84 \%)$ & $1.84(20 \%)$ & $9.61(104 \%)$ & \\
34 & $\mathrm{Zn}+$ & $13.49^{\mathrm{a}}$ & $3.34^{\mathrm{b}}$ & & 0.21 \\
& $\mathrm{Zn}-$ & $4.71^{\mathrm{a}}$ & $2.49^{\mathrm{b}}$ & & 0.21 \\
& Difference & $8.78(95 \%)$ & $0.85(9 \%)$ & $9.63(104 \%)$ & \\
78 & $\mathrm{Zn}+$ & $13.86^{\mathrm{a}}$ & $1.03^{\mathrm{b}}$ & & 0.68 \\
& $\mathrm{Zn}-$ & $5.01^{\mathrm{a}}$ & $1.49^{\mathrm{b}}$ & & \\
& Difference & $8.85(96 \%)$ & $0.46(5 \%)$ & $9.31(101 \%)$ & \\
104 & $\mathrm{Zn}+$ & $13.50^{\mathrm{a}}$ & $0.98^{\mathrm{b}}$ & & 0.14 \\
& $\mathrm{Zn}-$ & $4.14^{\mathrm{a}}$ & $0.44^{\mathrm{b}}$ & & 0.24 \\
& Difference & $9.36(101 \%)$ & $0.54(6 \%)$ & $9.91(107 \%)$ & \\
\hline
\end{tabular}

' In each soil, the results of the samples incubated with and without added $\mathrm{Zn}$ were tested separately for each extraction.

Adsorption of added $\mathrm{Zn}$ into the non-exchangeable form was observed especially in the clay soil (18) where as much as $88 \%$ of added $\mathrm{Zn}$ was not extracted with $\mathrm{MgCl}_{2}$. This tendency was weaker in the loam (34) in which more than half of added $\mathrm{Zn}$ remained exchangeable. In mineral soils added $\mathrm{Zn}$ was more efficiently extracted by AAAc than by $\mathrm{MgCl}_{2}$ but in the organogenic soils these two solutions extracted added $\mathrm{Zn}$ equally effectively. Despite the low $\mathrm{pH}$ of the organogenic soils, a considerable part of added $\mathrm{Zn}$ was adsorbed into forms not dissolved by $\mathrm{MgCl}_{2}$ or AAAc. This may be due to the formation of organic complexes, and the extraction of this fraction seemed to require chelating agents (EDTA and DTPA).

AAAc-EDTA dissolved $81-92 \%$ of added $\mathrm{Zn}$, being thus the strongest extractant for added $\mathrm{Zn}$ in the two mineral soils and in the mull. In peat, AAAc-EDTA and DTPA were equal in efficiency. Despite its high pH, DTPA was a strong extractant for native and added $\mathrm{Zn}$ in organogenic soils, but in mineral soils DTPA was relatively less effective. As for added $\mathrm{Zn}$, the results of AAAc-EDTA extraction were less affected by soil characteristics than those of the other extractions.

Pyrophosphate extraction removed the bulk of added $\mathrm{Zn}$ from soil, the rest being dissolved by oxalate (Table 26). The residue of added $\mathrm{Zn}$ in the soil after pyrophosphate extraction seemed to be highest in the clay soil and lowest in the two organogenic soils. The recovery of added $\mathrm{Zn}$ was not affected by soil $\mathrm{pH}$. The apparent recovery of added $\mathrm{Zn}$ seemed even to exceed $100 \%$ in all soils. The recovery was calculated as the difference between the sums of $\mathrm{Zn}_{\text {py }}+\mathrm{Zn}_{\text {ox }}$ extracted from soils incubated with and without added $\mathrm{Zn}$. The confidence limits at the $95 \%$ level were $0.2-0.3 \mathrm{mg} \mathrm{dm}^{-3}$ for $\mathrm{Zn}_{\text {py }}$ and $0.1-0.2 \mathrm{mg} \mathrm{dm}^{-3}$ for $\mathrm{Zn}_{\text {ox }}$. The present results were within these limits.

\subsection{Discussion}

\subsubsection{Total Zn}

The $\mathrm{Zn}_{\text {tot }}$ in the surface soil material was higher than the results of spectrographic determination of $\mathrm{Zn}_{\text {tot }}$ published earlier in Finland (VUORINEN 1958, ERVIÖ and VIRRI 1965, SIPPOLA 1974). For example, in the study by SIPPOLA (1974) $\mathrm{Zn}_{\text {tot }}$ ranged from $20 \mathrm{mg} \mathrm{kg}^{-1}$ in sands to $78 \mathrm{mg} \mathrm{kg}^{-1}$ in heavy clays. It is not likely that $\mathrm{Zn}_{\text {tot }}$ of the soils in Finland has doubled in a few decades but the difference may be attributed to the different methodologies 
employed. Later $\mathrm{Zn}_{\text {tot }}$ determinations carried out in Finland, based on digestion with HF-containing acid mixtures and measurement of $\mathrm{Zn}$ by AAS (BAGHDADY and SIPPOLA 1983, KolJONEN and MALISA 1991), have yielded results of the same magnitude as those of the present study.

Because the methods of determining $\mathrm{Zn}_{\text {tot }}$ give different results, the following references include only studies in which unpolluted mineral soil samples have been completely decomposed with HF-containing acid mixtures and analyzed for $\mathrm{Zn}$ by AAS. The $\mathrm{Zn}_{\text {tot }}$ in soils of temperate climates, e.g. silt and clay loam soils of Denmark (TJELL and HOVMAND 1978), clay, loam and sandy soils of Germany (BAGHDADY and SIPPOLA 1983, LICHTFUSS and ANDRESEN 1983) and clay loam soils of various parts of Canada (BISHOP and MACEACHERN 1973, NIELSEN et al. 1986, LIANG et al. 1990), are similar to or slightly smaller than those in the respective textural classes of the present material. Clay and clay loam soils of warmer regions, e.g. Virginia and Georgia, USA (IYENGAR et al. 1981, SHUMAN 1985) and the Nile delta, Egypt (BAGHDADY and SIPPOLA 1983), have also had similar or slightly lower $\mathrm{Zn}_{\text {tot }}$ than occurs in texturally corresponding soils of Finland. However, in unpolluted soils of other countries, $\mathrm{Zn}_{\text {tot }}$ seldom exceeds $150 \mathrm{mg} \mathrm{kg}^{-1}$, a value commonly found in clay soils of Finland. In coarse sandy soils of warmer climates, i.e. Georgia, USA (SHUMAN 1985), and Australia (BRENNAN and GARTRELL $1990), \mathrm{Zn}_{\text {tot }}$ is commonly below $10 \mathrm{mg} \mathrm{kg}^{-1}$ which is less than in any of the coarse mineral soils of the present study.

A close correlation between clay content and $\mathrm{Zn}_{\text {tot }}$ is likely to be a consequence of the differences in soil mineralogy in the textural fractions (SIPPOLA 1974). The analyses of clay and silt plus very fine sand of three soils directly showed that the coarser fraction was poorer in $\mathrm{Zn}_{\text {tot }}$ than was clay. However, silt can occasionally be as rich in $\mathrm{Zn}_{\text {tot }}$ as is clay (ANDERSSON 1979, ARMOUR et al. 1990). This may be the explanation why the unpolluted soils of Kuhmoinen (soil 21) and Hollola (soil 38) had a higher $\mathrm{Zn}_{\text {tot }}$ than the other soils of similar clay contents.

The negative correlation between $\mathrm{Zn}_{\text {tot }}$ and or- ganic $\mathrm{C}$ in organogenic soils reflects the origin of $\mathrm{Zn}_{\text {tot }}$ in mineral material. The studies on the vertical distribution of $\mathrm{Zn}$ emphasize that $\mathrm{Zn}_{\text {tot }}$ in organogenic soils was dependent on $\mathrm{Zn}_{\text {tot }}$ of the mineral soil below the organogenic layers. Organogenic soils (profile P6 from Jokioinen and the sample pair from Forssa) on a clayey subsoil were rich in $\mathrm{Zn}_{\text {tot }}$. On the contrary, the Carex peat profile P7 (Muhos), most probably also profile P5 (Sotkamo), had developed on coarse mineral soils poor in $\mathrm{Zn}_{\text {tot }}$ with the consequence that also the organogenic layers were poor in $\mathrm{Zn}_{\text {tot }}$.

In mull and peat soils, the mean $\mathrm{Zn}_{\text {tot }}$ was 48.7 and $35.1 \mathrm{mg} \mathrm{kg}^{-1}$, respectively, while a higher mean of $65.5 \mathrm{mg} \mathrm{kg}^{-1}$ was measured in 55 cultivated Histosols of Canada (LEVESQUE and MATHUR 1986). Nine out of the 20 peat soils of the present study contained less $\mathrm{Zn}$ than was the minimum $\left(28.5 \mathrm{mg} \mathrm{kg}^{-1}\right)$ in the peat soils of Canada. This comparison confirms that soils extremely poor in $\mathrm{Zn}_{\text {tot }}$ prevail among cultivated peat soils of Finland. Moreover, the results of URVAS et al. (1992) suggest that the peat soils of this study did not even contain the poorest ones occurring in Finland. However, $\mathrm{Zn}_{\text {tot }}$ in cultivated peat soils of Finland commonly exceeds that in virgin peatlands of Germany where a $\mathrm{Zn}_{\text {tot }}$ of $5-50 \mathrm{mg} \mathrm{kg}^{-1}$ (mean $20 \mathrm{mg}$ $\mathrm{kg}^{-1}$ ) has been measured (TEICHER et al. 1987).

\subsubsection{Fractions of soil $\mathrm{Zn}$}

The decreasing trend of $\mathrm{Zn}_{\mathrm{ex}}$ with increasing soil $\mathrm{pH}$ agrees with the results of several studies (SIMS and PATRICK 1978, NIELSEN et al. 1986, SIMS 1986, PALKO and Yli-HALla 1990), reflecting the corresponding increase of specific adsorption of $\mathrm{Zn}$. In mineral soils, $\mathrm{Zn}_{\mathrm{ex}}$ was of the same level as in other studies on acid mineral soils (IYENGAR et al. 1981, SHUMAN 1985, NIELSEN et al. 1986). Even in very acid clay soils $\mathrm{Zn}$ tended to be bound by covalent forces to a larger extent than in the coarsest mineral soils of similar $\mathrm{pH}$. This may reflect the abundance of sites capable of specific adsorption of $\mathrm{Zn}$ in clay soils, which were richer in organic matter and $\mathrm{Fe}$ oxide, important components adsorbing $\mathrm{Zn}$ in acid soil (McBRIDE and BLASIAK 1979, BRÜMMER et al. 
1983, TILler et al. 1984, PULFORD 1986). In organogenic soils, the high percentage of $\mathrm{Zn}_{\text {tot }}$ in exchangeable form was probably attributable to the strong acidity in these soils. In a few peat soils, more than $30 \%$ of $\mathrm{Zn}_{\text {tot }}$ was exchangeable, which suggests that the small native reserves of $\mathrm{Zn}$ in these soils may even be susceptible to leaching.

A few observations corroborate that sequential pyrophosphate and oxalate extractions dissolved $\mathrm{Zn}$ by and large from different soil components. First, $\mathrm{Zn}_{\text {py }}\left(\mathrm{mg} \mathrm{dm}^{-3}\right)$ was approximately equal in all soil classes while $\mathrm{Zn}_{\text {ox }}$ decreased in the mineral soils with decreasing clay content. Second, unlike $\mathrm{Zn}_{\text {py }}, \mathrm{Zn}_{\text {ox }}$ correlated significantly with $\mathrm{Zn}_{\text {tot. }}$. The fraction of $\mathrm{Zn}_{\text {py }}$ has been assumed to consist of $\mathrm{Zn}$ bound by organic matter. In the present study $\mathrm{Zn}_{\mathrm{py}}$ or complexed $\mathrm{Zn}\left(\mathrm{Zn}_{\text {py }}-\mathrm{Zn}_{\mathrm{ex}}\right)$ did not correlate with organic $\mathrm{C}$, but the dark color of the pyrophosphate extracts and the appearance of the soil after the extraction suggest effective removal of organic matter, with the consequence that also most $\mathrm{Zn}$ bound by organic matter was probably extracted. Pyrophosphate may also dissolve $\mathrm{Zn}$ from other sources. Oxides of $\mathrm{Fe}, \mathrm{Al}$ and $\mathrm{Mn}$ are major adsorbents for $\mathrm{Zn}$ added to soil (e.g. MuLLINS et al. 1982, McBRIDE 1989). In an incubation experiment of the present study the bulk of $\mathrm{Zn}$ added to soil was extracted with pyrophosphate and only a minor part was recovered as $\mathrm{Zn}_{\text {ox }}$ which was supposed to represent sesquioxide-bound $\mathrm{Zn}$. This observation indirectly suggests that at least some $\mathrm{Zn}$ from sesquioxides is extracted with pyrophosphate. The hypothesis is supported by an observation that pyrophosphate dissolves Fe from sesquioxides (BASCOMB 1968).

There was some evidence that in mineral soils the occurrence of $\mathrm{Zn}_{\text {ox }}$ may indeed be connected to Fe oxides. There was a correlation between $\mathrm{Zn}_{\text {ox }}$ and $\mathrm{Fe}_{\mathrm{ox}}$, and the lowest $\mathrm{Zn}_{\mathrm{ox}}$ exclusively occurred in the mineral soils poorest in $\mathrm{Fe}_{\mathrm{ox}}$. Several organogenic soils were also rich in $\mathrm{Fe}_{\mathrm{ox}}$, but contrary to the mineral soils this was not connected to the abundance of $\mathrm{Zn}_{\text {ox }}$. Moreover, in organogenic soils $\mathrm{Zn}_{\text {ox }}$ did not correlate with $\mathrm{Zn}_{\text {res }}$ or organic $\mathrm{C}$ which reflect the quantity of mineral material in the soil. Therefore, the source of $\mathrm{Zn}_{\mathrm{ox}}$ in organogenic soils requires further research.
The mean percentage of $\mathrm{Zn}_{\text {ox }}$ was low compared to the results of comparable sequential extraction studies from Georgia and Virginia, USA (SHUMAN 1979, IYENGAR et al. 1981), and from the Nile delta, Egypt (ELSOKKARY 1979). In those soils, scarce in organic matter and rich in crystalline $\mathrm{Fe}$ oxide, $\mathrm{Zn}_{\text {ox }}$ was the major fraction of secondary $\mathrm{Zn}$, amounting to $25 \%$ of $\mathrm{Zn}_{\text {tot }}$. Inversely, in the temperate soils of Canada (NIELSEN et al. 1986, LIANG et al. 1990) the $\mathrm{Zn}_{\mathrm{ox}}$ fraction was of the same magnitude (below $5 \%$ of $\mathrm{Zn}_{\text {tot }}$ ) as in the present material. Oxalate is not selective for poorly crystalline oxides but over time also crystalline oxides are dissolved (BORGGAARD 1979, 1992). In the present sequential extraction, poorly crystalline oxides and $\mathrm{Zn}$ bound by them may have been removed already in the pyrophosphate treatment and only the $\mathrm{Zn}$ bound to more crystalline oxides may have remained in the successive oxalate extraction. The scarcity of $\mathrm{Zn}_{\mathrm{ox}}$ in temperate soils may thus be attributed to the small quantity of crystalline oxides, owing to the young age and high content of organic matter which retards crystallization. The hypothesis presented above may be valid especially in organogenic soils most of which were poor in $\mathrm{Zn}_{\text {ox }}$.

Pyrophosphate and oxalate extractions completely removed $\mathrm{Zn}$ which had recently been added to the soil. The strong extraction power of these solutions was also shown by PAYNE et al. (1988) who observed that $\mathrm{Zn}$ added to a Rhodic Paleustult (560 kg Zn ha ${ }^{-1}$ during 17 years) was recovered as $\mathrm{Zn}_{\text {py }}$ and $\mathrm{Zn}_{\text {ox }}$, but there was no accumulation in the residual fraction. It seems therefore justified to regard the sum $Z_{\text {py }}+Z_{\text {ox }}$ as the quantity of secondary $\mathrm{Zn}$.

In most studies from other countries, the percentage of $\mathrm{Zn}_{\text {res }}$ in mineral soils has been lower than that in the present mineral soils where approximately $90 \%$ of soil $\mathrm{Zn}$ occurred as $\mathrm{Zn}_{\text {res. }}$. For example, in soils of the British Columbia and Saskatchewan, Canada (NIELSEN et al. 1986, LIANG et al. 1990 ), $\mathrm{Zn}_{\text {res }}$ amounted to $71 \%$ and $83 \%$ (ranges $46-93 \%$ and $69-91 \%$, respectively). Results of that level have also been obtained in soils of Delaware and Georgia, USA (IYENGAR et al. 1981, SHUMAN 1985), while in alluvial soils of Egypt, $\mathrm{Zn}_{\text {res }}$ 
was only $45 \%$ of $\mathrm{Zn}_{\text {tot }}$ (range $39-61 \%$ ) (ELSOKKARY 1979). The higher percentage of $\mathrm{Zn}_{\text {res }}$ in the present study reflects the young age of soils of Finland. The result also shows that the cultivated soils of Finland are not polluted with $\mathrm{Zn}$ because in polluted soils $\mathrm{Zn}_{\text {res }}$ represents a smaller fraction of $\mathrm{Zn}_{\text {tot }}$ (LÅG and ELSOKKARY 1978, RÄSÄNEN and HÄMÄLÄINEN 1991). The high percentage of secondary $\mathrm{Zn}$ in the organogenic soils reflects the scarcity of primary minerals in these soils.

Application of manures, sludges and $\mathrm{Zn}$-containing mineral fertilizers as well as atmospheric deposition of $\mathrm{Zn}$ can result in excessive accumulation of secondary $\mathrm{Zn}$ in surface soil (BERNDT and KERSHAw 1989, DRIEL and SMILDE 1990). Owing to mineral additives of fodder, manures in Finland commonly contain more than $200 \mathrm{mg} \mathrm{Zn} \mathrm{kg}^{-1}$ in the dry matter (KEMPPAINEN 1989). The present results showed that also in Finland there are soils where abundant use of manure has resulted in elevated reserves of secondary $\mathrm{Zn}$. The high concentration of $\mathrm{Zn}$ in soil 71 of Harjavalta was probably due to atmospheric deposition of $\mathrm{Zn}$ from the local metal industry which for example in 1988 emitted $100000 \mathrm{~kg}$ of $\mathrm{Zn}$, approximately $17 \%$ of all industrial $\mathrm{Zn}$ emissions of the country (AUNELA and LARJAVA 1990). Even though this single soil sample is not necessarily representative, this observation warrants concern for excessive $\mathrm{Zn}$ content of soil in the vicinity of metal industry. However, the $\mathrm{Zn}$ concentration of this sample was much lower than the extreme values exceeding $1000 \mathrm{mg} \mathrm{kg}^{-1}$ in the secondary fractions in soils heavily polluted by Zn (ELSOKKARY and LÅG 1978, FOLKESON and ANDERSSON-BringMARK 1988, DELAUNE et al. 1989, JORDAO and NiCKLESS 1989). Also in Finland, highly elevated concentrations of $\mathrm{Zn}$ have earlier been reported in lake shore sediments and surface soils of industrial areas (RÄSÄNEN and HÄMÄLÄINEN 1991).

\subsubsection{AAAc-EDTA extractions}

In unpublished material of Soil Analysis Service Ltd., the means of $\mathrm{Zn}_{\mathrm{Ac}}$ were 5.0, 6.1 and $4.9 \mathrm{mg}$ $\mathrm{dm}^{-3}$ in the 1262,10240 and 11701 analyses carried out in 1986, 1987 and 1988, respectively (results available at Soil Analysis Service Ltd., P.O. Box 500, FIN-50101 MIKKELI). Also the means and distributions of $\mathrm{Zn}_{\mathrm{Ac}}$ in 2015 cultivated grassland soils of Finland (SIPPOLA and TARES 1978) were of the same magnitude as those of the present material. On the contrary, SILLANPÄÄ (1982) and URVAS et al. (1992) presented results on 90 mineral soils and 112 organogenic soils in which $\mathrm{Zn}_{\mathrm{Ac}}$ was considerably smaller (mean 2.7 and $2.1 \mathrm{mg} \mathrm{dm}^{-3}$, respectively). Because the present results correspond to those of the large materials of Soil Analysis Service Ltd. and SIPPOLA and TARES (1978), it is justified to conclude that the observations made on the material can be extended to the cultivated soils of Finland in general.

The extractant AAAc-EDTA consists of three components: (1) acetic acid, (2) ammonium acetate and (3) $\mathrm{Na}_{2}$-EDTA. The chemical nature of $\mathrm{Zn}_{\mathrm{Ac}}$ can be assessed by studying the fractions which might be extracted by each component alone. It is likely that the aqueous solution extracts water-soluble $\mathrm{Zn}$, and $\mathrm{Zn}^{2+}$ bound by electrostatic forces is exchanged by $\mathrm{NH}_{4}{ }^{+}$cations of the solution. AAAcEDTA extracted more $\mathrm{Zn}$ than did $\mathrm{MgCl}_{2}$, the difference being especially pronounced at the high $\mathrm{pH}$ range of the experimental soils. In several studies, $2.5 \% \mathrm{CH}_{3} \mathrm{COOH}$ has been used in the extraction of $\mathrm{Zn}$ specifically adsorbed on the surfaces of sesquioxides (ELSOKKARY and LÅg 1978, IYENGAR et al. 1981, PAYNE et al. 1988). In AAAc-EDTA, the concentration of acetic acid is $3 \%$ and therefore it is likely that specifically adsorbed $\mathrm{Zn}$ is extracted also by AAAc-EDTA. This assumption is supported by the observation that increasing clay content enhanced the extraction power of AAAc-EDTA in relation to $\mathrm{MgCl}_{2}$ in mineral soils. In clay soils the number of sites available for specific adsorption of $\mathrm{Zn}$ is probably higher than in coarse mineral soils, owing to the higher contents of $\mathrm{Fe}_{\text {ox }}$ and $\mathrm{Al}_{\text {ox. }}$.

EDTA has been added to the AAAc solution in order to enhance the extraction of metallic trace elements (LAKANEN and ERVIÖ 1971). However, the $\mathrm{Zn}$-EDTA complex is most stable at $\mathrm{pH} 6.5$ (LINDSAY 1972), and $\mathrm{pH} 4.65$ should theoretically be far from ideal in order to facilitate effective extraction of $\mathrm{Zn}$ by EDTA. Yet, the extraction ex- 
periment (Section 3.4) showed that EDTA increased the extractability of both native and added $\mathrm{Zn}$ especially from organogenic soils as compared to the extraction by AAAc alone. Moreover, the extraction power of AAAc-EDTA was at least equal to that of DTPA where the $\mathrm{pH} 7.3$ corresponds to the $\mathrm{pH}$ of maximum stability of the $\mathrm{Zn}$ DTPA complex (LINDSAY 1972). EDTA is an effective extractant for organically bound $\mathrm{Cu}$ (RASHID 1974, STEVENSON 1982, p. 40). It has also been observed that the addition of EDTA in the Mehlich 2 extractant $\left(\mathrm{CH}_{3} \mathrm{COOH}-\mathrm{NH}_{4} \mathrm{Cl}-\mathrm{NH}_{4} \mathrm{~F}\right.$ - $\mathrm{HCl}$ ) enhanced the extractability of soil $\mathrm{Zn}$ especially when the content of organic matter increased (MEHLICH 1984). It may thus be assumed that also AAAc-EDTA extracts $\mathrm{Zn}$ bound by organic matter even at $\mathrm{pH} 4.65$. However, organic matter is more effectively extracted by pyrophosphate than by EDTA (McLAREN and CRAWFORD 1973). This observation seems to apply also to organically bound $\mathrm{Zn}$ because in mineral soils the extraction power of AAAc-EDTA decreased in relation to pyrophosphate with increasing content of organic $\mathrm{C}$. The close correlation between $\mathrm{Zn}_{\mathrm{Ac}}$ and $\mathrm{Zn}_{\text {py }}$ suggested that AAAc-EDTA extracted $\mathrm{Zn}$ mainly from the same sources as did pyrophosphate. It may thus be concluded that, in addition to water-soluble and exchangeable $\mathrm{Zn}$, the AAAc-EDTA extracts $\mathrm{Zn}$ specifically adsorbed by sesquioxides and organic matter.
GOLDSCHMIDT (1937) observed in Germany and HIBBARD (1940) in California, USA higher concentrations of $\mathrm{Zn}$ extracted from surface soils as compared to the subsoil. They both suggested independently that this may be due to bioaccumulation as a result of uplift of $\mathrm{Zn}$ from deeper layers by plant roots. When plant residues are decayed, $\mathrm{Zn}$ from plant tissue is mineralized and retained in the surface soil. The hypothesis of bioaccumulation is also corroborated by the observations on the present mineral soil profiles and earlier in a more extensive material of peat soils of Finland (URVAS 1986). In the present fine-textured mineral soil profiles, the minimum $\mathrm{Zn}_{\mathrm{Ac}}$ occurred in the upper part of subsoil, and a higher concentration of $\mathrm{Zn}_{\mathrm{Ac}}$ was measured deeper in the profile. Zinc uptake by plant roots may have depleted the reserves of $\mathrm{Zn}_{\mathrm{Ac}}$ in the upper part of subsoil but not in the deeper layers because roots of herbaceous plants do not penetrate to a considerable extent deeper than $1 \mathrm{~m}$ (DWYER et al. 1988). This observation also suggests that bioaccumulation of $\mathrm{Zn}$ is an important factor contributing to $\mathrm{Zn}_{\mathrm{Ac}}$ in the plough layer. Absence of correlation between $\mathrm{Zn}_{\text {res }}$ and $\mathrm{Zn}_{\mathrm{Ac}}$ also suggests that a considerable part of secondary $\mathrm{Zn}$ in the surface soil may not have been released from the primary minerals residing in the plough layer but may have been brought there from external sources, e.g. by bioaccumulation and atmospheric deposition.

\section{AVAILABILITY OF SOIL AND FERTILIZER ZINC TO RYEGRASS IN POT EXPERIMENTS}

\subsection{Availability of soil $\mathrm{Zn}$}

\subsubsection{Experimental}

In order to examine the potential of soil to supply plants with $\mathrm{Zn}$, a pot experiment was arranged with 107 plough layer samples (Appendix 2). Four crops of Italian ryegrass (Lolium multiflorum, Lam.) were grown in plastic boxes containing $0.2 \mathrm{dm}^{3}$ of ground $(<2 \mathrm{~mm})$ soil (two replicates). Nutrients, except $\mathrm{Zn}$, were applied to each crop at the following rates $\left(\mathrm{mg} \mathrm{dm}^{-3}\right.$ of soil) as analytical grade chemicals:

$\begin{array}{lcl}\text { Element } & \text { Rate, } \mathrm{mg} \mathrm{dm}^{-3} & \text { Compound } \\ \mathrm{N} & 300 & \mathrm{NH}_{4} \mathrm{NO}_{3} \\ \mathrm{P} & 80 & \mathrm{KH}_{2} \mathrm{PO}_{4} \\ \mathrm{~K} & 200 & \mathrm{KCl}, \mathrm{KH}_{2} \mathrm{PO}_{4} \\ \mathrm{Mg} & 50 & \mathrm{MgSO}_{4} \cdot 7 \mathrm{H}_{2} \mathrm{O} \\ \mathrm{S} & 67 & \mathrm{MgSO}_{4} \cdot 7 \mathrm{H}_{2} \mathrm{O}\end{array}$


Micronutrient fertilization, including $5 \mathrm{mg} \mathrm{S}$ $\mathrm{dm}^{-3}$, was applied at the beginning of the experiment and after the second harvest at the following rates:

$\begin{array}{lcl}\text { Element } & \text { Rate, } \mathrm{mg} \mathrm{dm}^{-3} & \text { Compound } \\ \mathrm{Cu} & 3 & \mathrm{CuSO}_{4} \cdot 5 \mathrm{H}_{2} \mathrm{O} \\ \mathrm{Mn} & 4 & \mathrm{MnSO}_{4} \cdot 4 \mathrm{H}_{2} \mathrm{O} \\ \mathrm{Fe} & 2 & \mathrm{FeSO}_{4} \cdot 7 \mathrm{H}_{2} \mathrm{O} \\ \text { B } & 0.5 & \mathrm{H}_{3} \mathrm{BO}_{3} \\ \mathrm{Mo} & 1 & \mathrm{Na}_{2} \mathrm{MoO}_{4} \cdot 2 \mathrm{H}_{2} \mathrm{O}\end{array}$

At the beginning of the experiment, the fertilizer solutions were mixed in the soil. For the subsequent crops they were pipetted onto the surface of the soil. To prevent a decrease of $\mathrm{pH}$ in the course of the trial due to $\mathrm{N}$ fertilization and root exudates, $250 \mathrm{mg}$ of $\mathrm{Ca}(\mathrm{OH})_{2}\left(6.8 \mathrm{meq} \mathrm{dm}^{-3}\right)$ was mixed into each pot. The seeds ( $250 \mathrm{mg}$ per pot) were covered with 150 $\mathrm{ml}$ of quartz sand washed with $3 \mathrm{M} \mathrm{HCl}$. The pots were watered with deionized water once or twice a

Table 27. Change in $\mathrm{pH}$ during the pot experiment in the five soil classes.

\begin{tabular}{lccc}
\hline Soil class & \multicolumn{3}{c}{ Change in pH } \\
\cline { 2 - 4 } & Mean & $\mathrm{s}$ & Range \\
\hline Clay & $-0.24^{\mathrm{b}}$ & 0.21 & $-0.57-0.06$ \\
Silt, loam, & $-0.31^{\mathrm{b}}$ & 0.22 & $-0.61-0.10$ \\
very fine sand & & & \\
Fine sand, moraine & $-0.35^{\mathrm{b}}$ & 0.15 & $-0.66--0.05$ \\
Mull & $-0.19^{\mathrm{ab}}$ & 0.19 & $-0.40-0.13$ \\
Peat & $-0.10^{\mathrm{a}}$ & 0.15 & $-0.36-0.18$ \\
\hline
\end{tabular}

day. The first crop was cut 29 days after sowing, and the average growing period of the successive crops was 24 days. The yields were dried at $60^{\circ} \mathrm{C}$, weighed and analyzed for $\mathrm{Zn}$. At the end of the experiment, the $\mathrm{pH}$ of the soil in the pot was determined. In spite of the lime application, soil $\mathrm{pH}$ decreased during the experiment (Table 27).

\subsubsection{Dry matter yields}

The mean deviation of the total dry matter yield between the two replicates was $0.30 \mathrm{~g}$ per pot, or $3.1 \%$ of the average yield. The average total dry matter production (sum of four crops) in clay, silt loam and very fine sand soils was slightly higher than that of the organogenic soils (Table 28). Dry matter yields did not correlate with any of the indices of secondary $\mathrm{Zn}$ of soil. Dry matter production in mineral soils was positively correlated with $\mathrm{Zn}_{\text {tot }}$ $\left(\mathrm{r}=0.48^{* * *}\right)$ and soil $\mathrm{pH}\left(\mathrm{r}=0.34^{* * *}\right)$. The correlation between $\mathrm{Zn}_{\text {tot }}$ and the yield reflects the trend that fine sand and moraine soils, poorer in $\mathrm{Zn}_{\text {tot }}$ than the clay soils, tended to produce smaller yields than did the more fine-textured soils. In organogenic soils, dry matter yield did not correlate significantly with the soil properties measured.

\subsubsection{Zinc concentration and uptake}

The mean $\mathrm{Zn}$ concentration of the grass within each yield (Table 29) did not differ markedly from one soil class to another (HSD values not presented).

Table 28. Dry matter yields of ryegrass. ${ }^{1}$

\begin{tabular}{|c|c|c|c|c|c|c|c|}
\hline \multirow[b]{2}{*}{ Soil class } & \multirow[b]{2}{*}{$\mathrm{n}$} & \multicolumn{4}{|c|}{ Successive crop, g per pot } & \multicolumn{2}{|c|}{ Sum of yields, $g$ per pot } \\
\hline & & I & II & III & IV & Mean & Range \\
\hline Clay & 25 & 2.27 & 3.36 & 2.52 & 2.13 & $10.28^{\mathrm{ab}}$ & 9.13-11.52 \\
\hline Silt, loam, very fine sand & 20 & 2.41 & 3.39 & 2.48 & 2.15 & $10.43^{\mathrm{a}}$ & $9.45-11.48$ \\
\hline Fine sand, moraine & 28 & 2.26 & 2.97 & 2.38 & 2.10 & $9.71^{\mathrm{bc}}$ & $7.96-11.43$ \\
\hline Mull & 14 & 2.15 & 2.90 & 2.34 & 2.00 & $9.39^{c}$ & $7.69-10.39$ \\
\hline Peat & 20 & 2.11 & 2.78 & 2.34 & 1.97 & $9.20^{\mathrm{c}}$ & $7.78-11.31$ \\
\hline
\end{tabular}

${ }^{1}$ Means in each column were tested separately. 
Table 29. Zinc concentration $\left(\mathrm{mg} \mathrm{kg}^{-1}\right)$ of ryegrass in the pot experiment. The results of the fine sand and moraine soils excluding those of soil 71 are presented in parentheses.'

\begin{tabular}{|c|c|c|c|c|}
\hline Soil class & Crop & Mean & s & Range \\
\hline $\begin{array}{l}\text { Clay } \\
\mathrm{n}=25\end{array}$ & $\begin{array}{l}\text { I } \\
\text { II } \\
\text { III } \\
\text { IV } \\
\text { HSD }_{0.05}\end{array}$ & $\begin{array}{c}32.4^{\mathrm{a}} \\
23.4^{\mathrm{b}} \\
36.2^{\mathrm{a}} \\
36.8^{\mathrm{a}} \\
4.0\end{array}$ & $\begin{array}{r}10.6 \\
6.9 \\
11.2 \\
11.5\end{array}$ & $\begin{array}{l}13.5-49.5 \\
12.0-34.5 \\
19.0-64.5 \\
16.5-61.0\end{array}$ \\
\hline $\begin{array}{l}\text { Fine silt, loam, very fine sand } \\
\mathrm{n}=20\end{array}$ & $\begin{array}{l}\text { I } \\
\text { II } \\
\text { III } \\
\text { IV } \\
\text { HSD }_{0.05}\end{array}$ & $\begin{array}{c}27.5^{\mathrm{b}} \\
20.6^{\mathrm{c}} \\
31.8^{\mathrm{a}} \\
29.4^{\mathrm{ab}} \\
3.9\end{array}$ & $\begin{array}{r}10.4 \\
6.8 \\
7.6 \\
7.8\end{array}$ & $\begin{array}{l}11.5-50.5 \\
11.0-38.0 \\
18.5-42.0 \\
16.0-44.0\end{array}$ \\
\hline $\begin{array}{l}\text { Fine sand, moraine } \\
\mathrm{n}=28\end{array}$ & $\begin{array}{l}\text { I } \\
\text { II } \\
\text { III } \\
\text { IV } \\
\text { HSD }_{0.05}\end{array}$ & $\begin{array}{cc}30.1^{\mathrm{b}} & \left(28.5^{\mathrm{b}}\right) \\
27.0^{\mathrm{b}} & \left(24.9^{\mathrm{b}}\right) \\
38.6^{\mathrm{a}} & \left(34.1^{\mathrm{a}}\right) \\
42.0^{\mathrm{a}} & \left(36.3^{\mathrm{a}}\right) \\
7.8 & (5.3)\end{array}$ & $\begin{array}{ll}13.7 & (10.7) \\
18.7 & (10.2) \\
26.1 & (13.3) \\
34.2 & (15.7)\end{array}$ & $\begin{array}{ll}14.0-75.5 & (54.5) \\
11.0-109 & (52.0) \\
17.5-154 & (67.0) \\
16.0-198 & (76.0)\end{array}$ \\
\hline $\begin{array}{l}\text { Mull } \\
\mathrm{n}=14\end{array}$ & $\begin{array}{l}\text { I } \\
\text { II } \\
\text { III } \\
\text { IV } \\
\text { HSD }_{0.05}\end{array}$ & $\begin{array}{c}35.0^{\mathrm{a}} \\
25.1^{\mathrm{b}} \\
31.4^{\mathrm{a}} \\
30.6^{\mathrm{a}} \\
4.8\end{array}$ & $\begin{array}{l}5.9 \\
6.0 \\
8.7 \\
9.1\end{array}$ & $\begin{array}{l}21.5-42.0 \\
13.0-35.5 \\
15.5-47.0 \\
15.5-46.0\end{array}$ \\
\hline $\begin{array}{l}\text { Peat } \\
n=20\end{array}$ & $\begin{array}{l}\text { I } \\
\text { II } \\
\text { III } \\
\text { IV } \\
\text { HSD }_{0.05}\end{array}$ & $\begin{array}{c}34.3^{\mathrm{a}} \\
28.2^{\mathrm{b}} \\
30.8^{\mathrm{ab}} \\
30.0^{\mathrm{b}} \\
3.6\end{array}$ & $\begin{array}{r}10.2 \\
8.7 \\
10.8 \\
10.0\end{array}$ & $\begin{array}{l}17.0-56.5 \\
13.0-49.0 \\
11.5-57.5 \\
12.0-53.3\end{array}$ \\
\hline
\end{tabular}

' Results of each soil class have been tested separately.

Table 30. Mean $\mathrm{Zn}$ uptake of grass by the four yields. ${ }^{1}$

\begin{tabular}{lccccc}
\hline \multirow{2}{*}{ Soil class } & \multicolumn{3}{c}{ Zn uptake $\left(\mu \mathrm{g} \mathrm{dm}^{-3}\right)$ by successive crops } & & $\mathrm{HSD}_{0.05}$ \\
\cline { 2 - 5 } & I & II & III & IV & \\
\hline Clay & $400^{-3}$ & $380^{\mathrm{a}}$ & $400^{\mathrm{a}}$ & $410^{\mathrm{a}}$ & 74 \\
Silt, loam very fine sand & $330^{\mathrm{b}}$ & $350^{\mathrm{a}}$ & $400^{\mathrm{a}}$ & $320^{\mathrm{b}}$ & 51 \\
Fine sand, moraine & $330^{\mathrm{b}}$ & $400^{\mathrm{ab}}$ & $440^{\mathrm{a}}$ & $450^{\mathrm{a}}$ & 81 \\
-soil 71 excluded & $310^{\mathrm{b}}$ & $370^{\mathrm{a}}$ & $400^{\mathrm{a}}$ & $380^{\mathrm{a}}$ & 61 \\
Mull & $380^{\mathrm{a}}$ & $370^{\mathrm{a}}$ & $370^{\mathrm{a}}$ & $310^{\mathrm{b}}$ & 50 \\
Peat & $360^{\mathrm{a}}$ & $390^{\mathrm{a}}$ & $360^{\mathrm{a}}$ & $290^{\mathrm{a}}$ & 49 \\
\hline
\end{tabular}

${ }^{1}$ Results of each soil class have been tested separately.

Each soil class, particularly fine sand and moraine, contained a few soils (especially soil 71) which produced grass very rich in $\mathrm{Zn}$ as compared to the bulk of the material. There was a tendency of $\mathrm{Zn}$ concentration to be the lowest in the second crop in which the largest quantity of dry matter was pro- duced. In peat soils, the mean $\mathrm{Zn}$ content in the fourth crop was lower than that in the first one, while in the mineral soils $\mathrm{Zn}$ concentration in the last two crops was at least as high as in the first one.

Uptake of $\mathrm{Zn}$ (Table 30) was calculated by multiplying the dry matter yield with $\mathrm{Zn}$ concentration 
of the respective grass sample. Because the roots were not weighed and analyzed, $\mathrm{Zn}$ uptake represents the quantity of $\mathrm{Zn}$ transported to the aboveground parts of ryegrass. In clay soils, $\mathrm{Zn}$ uptake remained constant from crop to crop, whereas in silt, loam and very fine sand soils, the maximum $\mathrm{Zn}$ uptake occurred in the third crop. Instead, in the fine sand and moraine soils, $\mathrm{Zn}$ uptake increased towards the end of the experiment, despite decreasing dry matter production. Because both $\mathrm{Zn}$ concentration and uptake increased, the $\mathrm{Zn}$ supply to plants can be assumed to increase over time in these soils. In organogenic soils, $\mathrm{Zn}$ uptake by the fourth crop was smaller than that by the three earlier ones. In peat soils, both concentration and uptake were smaller in the fourth crop, which may reflect a decreased $\mathrm{Zn}$ supply to the plants. Within a crop, the only statistically significant difference in $\mathrm{Zn}$ uptake between the five soil classes occurred in the fourth crop in which $\mathrm{Zn}$ uptake from clay soils was greater than that from the peat soils (HSD values not presented).

The cumulative $\mathrm{Zn}$ uptake in the four yields ranged from 620 to $6190 \mu \mathrm{g} \mathrm{dm}^{-3}$ of soil, mean $1470 \mu \mathrm{g} \mathrm{dm}^{-3}$. The mean deviation in $\mathrm{Zn}$ uptake between the replicates was $52 \mu \mathrm{g} \mathrm{dm}^{-3}$, corresponding to $3.7 \%$ of the mean. The differences in $\mathrm{Zn}$ uptake were much greater within each soil class than between the classes which did not differ significantly from one another. Correlation between plant $\mathrm{Zn}$ concentration and $\mathrm{Zn}$ uptake was very close in each of the four crops $\left(r=0.87^{* * *}-0.96^{* * *}\right)$ but negligible between the cumulative dry matter yield and $\mathrm{Zn}$ uptake $\left(\mathrm{r}=0.08^{\text {n.s. }}\right.$ and $\mathrm{r}=0.26^{\text {n.s. }}$ in mineral and organogenic soils, respectively). Thus, the quantity of $\mathrm{Zn}$ taken up was by and large determined by the $\mathrm{Zn}$ concentration of the plant material.

\subsubsection{Dependence of $\mathrm{Zn}$ uptake on soil properties}

The correlation coefficients between a few soil characteristics and the cumulative $\mathrm{Zn}$ uptake in the four crops are presented in Table 31. In the calculations, natural logarithms $\left(\log _{\mathrm{e}}\right)$ of soil $\mathrm{Zn}$ concentrations $\left(\mathrm{mg} \mathrm{dm}^{-3}\right)$ were used. The results of soil 71 were not included in the calculations. In organo-
Table 31. Linear correlation coefficients between soil characteristics and $\mathrm{Zn}$ uptake by the four ryegrass crops. Natural logarithms of soil $\mathrm{Zn}$ concentrations $\left(\mathrm{mg} \mathrm{dm}^{-3}\right)$ were used in the calculations.

\begin{tabular}{|c|c|c|}
\hline & $\begin{array}{l}\text { Mineral soils } \\
\mathrm{n}=72\end{array}$ & $\begin{array}{c}\text { Organogenic soils } \\
n=34\end{array}$ \\
\hline $\mathrm{Zn}_{\mathrm{Ac}}$ & $0.89^{* * *}$ & $0.80^{* \cdots}$ \\
\hline $\mathrm{Zn}_{\mathrm{py}}$ & $0.82^{* * *}$ & $0.83^{* * *}$ \\
\hline $\mathrm{Zn}_{\mathrm{ox}}$ & $0.51^{\cdots *}$ & $0.60^{* * *}$ \\
\hline $\mathrm{Zn}_{\mathrm{ex}}$ & $0.77^{* * *}$ & $0.68^{* * *}$ \\
\hline $\mathrm{Zn}_{\mathrm{py}}-\mathrm{Zn}_{\mathrm{ex}}$ & $0.64^{* * *}$ & $0.80^{\circ * *}$ \\
\hline $\mathrm{Zn}_{\mathrm{tot}}$ & $0.18^{\text {n.s. }}$ & $0.37^{\text {n.s. }}$ \\
\hline $\mathrm{pH}$ & $-0.27^{*}$ & $0.15^{\text {n.s. }}$ \\
\hline Organic C & $-0.03^{\text {n.s. }}$ & $-0.11^{\mathrm{nss} .}$ \\
\hline
\end{tabular}

genic soils, $\mathrm{Zn}$ uptake correlated most closely with $\mathrm{Zn}_{\text {py }}, \mathrm{Zn}_{\mathrm{Ac}}, \mathrm{Zn}_{\mathrm{ex}}$ and $\mathrm{Zn}_{\text {py }}-\mathrm{Zn}_{\text {ex }}$. In mineral soils, $\mathrm{Zn}$ uptake correlated more closely with $\mathrm{Zn}_{\mathrm{Ac}}$ than with $\mathrm{Zn}_{\text {ex }}$ and $\mathrm{Zn}_{\text {py }}-\mathrm{Zn}_{\mathrm{ex}}$, and more closely with $\mathrm{Zn}$ py than with $\mathrm{Zn}_{\text {py }}-\mathrm{Zn}_{\text {ex }}$. The partial correlation coefficients between $\mathrm{Zn}$ uptake and $\mathrm{Zn}_{\text {py }}-\mathrm{Zn}_{\text {ex }}$, when eliminating the effect of $\mathrm{Zn}_{\mathrm{ex}}$, were highly significant $\left(\mathrm{r}=0.56^{* * *}\right.$ and $0.65^{* * *}$ in mineral and organogenic soils, respectively), suggesting that also complexed $\mathrm{Zn}$ contributed to plant-available $\mathrm{Zn}$. The correlation coefficient with $\mathrm{Zn}_{\mathrm{ox}}$ was also significant, but the partial correlation coefficient between $\mathrm{Zn}_{\text {ox }}$ and $\mathrm{Zn}$ uptake, when the effect of $\mathrm{Zn}$ py was eliminated, was not statistically significant. The relationship between $\mathrm{Zn}_{\mathrm{Ac}}$ and $\mathrm{Zn}$ uptake in mineral and organogenic soils is presented in Figures 3 and 4, respectively.

In the multiple regression analysis, $\mathrm{Zn}_{\mathrm{Ac}}(\mathrm{mg}$ $\mathrm{dm}^{-3}$ ), soil $\mathrm{pH}$ and organic $\mathrm{C}(\%)$ explained $82 \%$ of the variation of the cumulative $\mathrm{Zn}$ uptake $\left(\mu \mathrm{g} \mathrm{dm}^{-3}\right.$ of soil) in mineral soils. In an equation consisting of $\mathrm{Zn}_{\text {py }}\left(\mathrm{mg} \mathrm{dm}^{-3}\right), \mathrm{Zn}_{\mathrm{ox}}\left(\mathrm{mg} \mathrm{dm}^{-3}\right)$ and $\mathrm{pH}$, the coefficient of multiple determination was slightly lower. At a given level of $\mathrm{Zn}_{\text {py }}, \mathrm{Zn}_{\text {ox }}$ and $\mathrm{Zn}_{\mathrm{Ac}}, \mathrm{Zn}$ uptake decreased with increasing soil $\mathrm{pH}$. According to the beta coefficients (Table 32 ), $\mathrm{Zn}_{\mathrm{Ac}}$ and $\mathrm{Zn}_{\text {py }}$ were by far the most important soil characteristics determining the magnitude of $\mathrm{Zn}$ uptake by the grass. The two equations for mineral soils $(\mathrm{n}=$ 72) were as follows: 


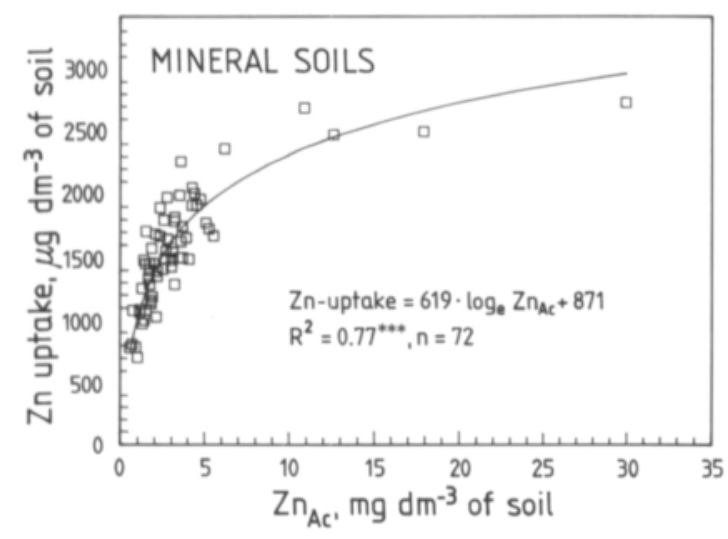

Fig. 3. Dependence of $\mathrm{Zn}$ uptake of four ryegrass crops on the concentration of soil $\mathrm{Zn}$ extracted by AAAc-EDTA $\left(\mathrm{Zn}_{\mathrm{Ac}}\right)$ in mineral soils.

$\mathrm{Zn}$ uptake $=593 \log _{\mathrm{e}} \mathrm{Zn}_{\mathrm{Ac}}-188 \mathrm{pH}-40.8 \mathrm{C}+2150$ $\mathrm{R}^{2}=0.82^{* * *}$

$\mathrm{Zn}$ uptake $=439 \log _{\mathrm{e}} \mathrm{Zn}_{\text {py }}+222 \log _{\mathrm{e}} \mathrm{Zn}_{\mathrm{ox}}-202 \mathrm{pH}$

$$
\begin{aligned}
& +1940 \\
& \mathrm{R}^{2}=0.73^{* * *}
\end{aligned}
$$

The dependence of $\mathrm{Zn}$ uptake of each crop on the characteristics of mineral soils was also studied. Within each crop, $\mathrm{Zn}_{\mathrm{Ac}}$ and $\mathrm{Zn}_{\text {py }}$ ( $\log _{\mathrm{e}}$ of the results expressed as $\mathrm{mg} \mathrm{dm}^{-3}$ ) were the most important soil characteristics explaining the variation of plant $\mathrm{Zn}$ uptake ( $\mu \mathrm{g} \mathrm{dm}^{-3}$ of soil) (Table 33). Soil pH was significant in the first two crops but lost significance towards the end of the experiment. Also the $\mathrm{pH}$ measured at the end of the experiment was used

Table 32. $t$-Values of the regression coefficients and beta coefficients $(\beta)$ of the independent variables of the regression equations explaining $\mathrm{Zn}$ uptake by ryegrass in mineral soils.

\begin{tabular}{lcr}
\hline Independent variable & \multicolumn{1}{c}{$\mathrm{t}$} & \multicolumn{1}{c}{$\beta$} \\
\hline $\log _{\mathrm{e}} \mathrm{Zn}_{\mathrm{Ac}}$ & $16.270^{* *}$ & 0.85 \\
$\mathrm{pH}^{1}$ & $-4.041^{* *}$ & -0.24 \\
Organic C & $-2.344^{*}$ & -0.14 \\
$\log _{\mathrm{e}} \mathrm{Zn}_{\mathrm{py}}$ & $6.837^{* *}$ & 0.61 \\
$\log _{\mathrm{e}} \mathrm{Zn}_{\mathrm{ox}}$ & $3.203^{* *}$ & 0.30 \\
$\mathrm{pH}^{2}$ & $-3.200^{* *}$ & -0.26 \\
\hline
\end{tabular}

1 in the equation with $\log _{\mathrm{e}} \mathrm{Zn}_{\mathrm{Ac}}$ and organic $\mathrm{C}$

${ }^{2}$ in the equation with $\log _{\mathrm{e}} \mathrm{Zn}_{\mathrm{py}}$ and $\mathrm{Zn}_{\mathrm{ox}}$

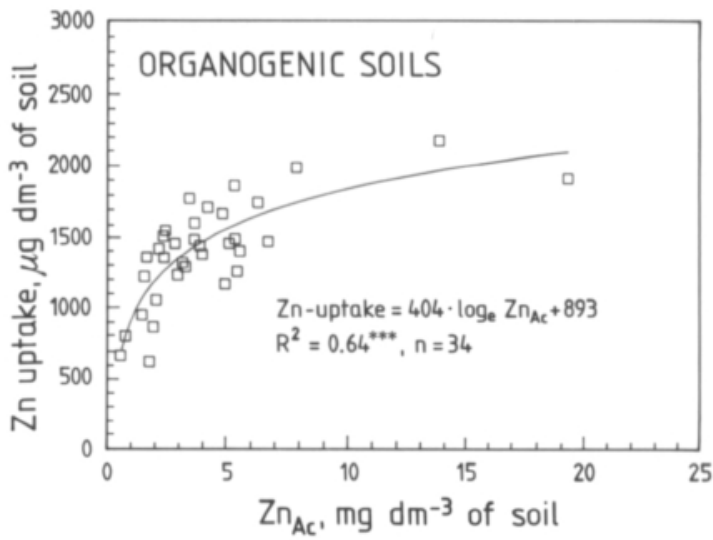

Fig. 4. Dependence of $\mathrm{Zn}$ uptake of four ryegrass crops on the concentration of soil $\mathrm{Zn}$ extracted by AAAc-EDTA $\left(\mathrm{Zn}_{\mathrm{Ac}}\right)$ in mineral soil.

as an independent variable, but it did not prove statistically significant even in the last two crops. On the contrary, $\mathrm{Zn}_{\mathrm{ox}}$ was significant in the last crop. Increasing clay content (\%) promoted $\mathrm{Zn}$ uptake, but increasing organic $\mathrm{C}(\%)$ had a negative impact. When $\mathrm{Zn}_{\text {py }}$ was divided into two components $\left(\mathrm{Zn}_{\text {ex }}\right.$ and $\left.\mathrm{Zn}_{\text {py }}-\mathrm{Zn}_{\text {ex }}\right)$ they were both significant (beta coefficients not shown), and the equations had nearly the same coefficients of multiple determination as those containing $\mathrm{Zn}_{\text {py }}$.

In multiple regression analyses of the results of organogenic soils, the cumulative $\mathrm{Zn}$ uptake ( $\mu \mathrm{g}$ $\mathrm{dm}^{-3}$ of soil) was explained only by $\mathrm{Zn}_{\mathrm{Ac}}\left(\mathrm{mg} \mathrm{dm}^{-3}\right)$ or $\mathrm{Zn}_{\text {py }}\left(\mathrm{mg} \mathrm{dm}^{-3}\right)$, without a statistically significant contribution of soil $\mathrm{pH}$ or $\mathrm{Zn}_{\text {ox }}$. The two alternative regression equations were as follows $(n=$ 34):

$\begin{aligned} \mathrm{Zn} \text { uptake }= & 404 \log _{\mathrm{e}} \mathrm{Zn}_{\mathrm{Ac}}+894 \\ \mathrm{R}^{2}=0.64^{* * *} & \end{aligned}$

$\mathrm{Zn}$ uptake $=389 \log _{\mathrm{e}} \mathrm{Zn}_{\text {py }}+863$

\subsubsection{Utilization of soil $\mathrm{Zn}$ reserves}

The relative utilization of $\mathrm{Zn}_{\text {tot }}$, expressed as the percentage of $\mathrm{Zn}_{\text {tot }}$ taken up by the four crops of ryegrass, averaged $5.1 \%$ of $\mathrm{Zn}_{\text {tot }}$ (median $2.2 \%$, 
Table 33. Beta coefficients of independent variables explaining $\mathrm{Zn}$ uptake of the four ryegrass crops (I-IV) in mineral soils $(n=72)$, as well as the coefficients of multiple determination $\left(R^{2}\right)$ of the respective regression equations. Natural logarithms of soil $\mathrm{Zn}$ concentrations $\left(\mathrm{mg} \mathrm{dm}^{-3}\right)$ were used in the calculations.

\begin{tabular}{|c|c|c|c|c|c|c|c|}
\hline Crop & $\mathrm{Zn}_{\mathrm{Ac}}$ & $\mathrm{Zn}_{\mathrm{py}}$ & $\mathrm{Zn}_{\mathrm{ox}}$ & $\mathrm{pH}$ & Org. C, \% & Clay, $\%$ & $\mathrm{R}^{2}$ \\
\hline I & 0.68 & - & - & -0.46 & n.s. & n.s. & $0.75^{\circ * *}$ \\
\hline I & - & 0.64 & n.s. & -0.42 & n.s. & n.s. & $0.71^{* \cdots}$ \\
\hline II & 0.76 & - & - & -0.37 & -0.16 & n.s. & $0.76^{* * *}$ \\
\hline II & - & 0.68 & n.s. & -0.36 & -0.24 & 0.17 & $0.65^{* * *}$ \\
\hline II & - & 0.66 & 0.24 & -0.36 & - & - & $0.62^{* \cdots}$ \\
\hline III & 0.82 & - & - & n.s. & -0.22 & 0.14 & $0.77^{* \cdots *}$ \\
\hline III & - & 0.79 & n.s. & n.s. & -0.29 & 0.26 & $0.71^{* \cdots *}$ \\
\hline III & - & 0.66 & 0.21 & n.s. & - & - & $0.64^{* \cdots}$ \\
\hline IV & 0.77 & - & - & n.s. & -0.24 & n.s. & $0.65^{* * *}$ \\
\hline IV & - & 0.61 & 0.24 & n.s. & -0.21 & n.s. & $0.64^{* * *}$ \\
\hline
\end{tabular}

- = Not included in the calculations.

Table 34. Relative utilization of $\mathrm{Zn}_{\text {tot }}$ and secondary $\mathrm{Zn}\left(\mathrm{Zn}_{\mathrm{py}}+\mathrm{Zn}_{\mathrm{ox}}\right)$ by ryegrass in the pot experiment.1

\begin{tabular}{|c|c|c|c|c|c|}
\hline \multirow[t]{2}{*}{ Soil class } & \multirow[t]{2}{*}{$\mathrm{n}$} & \multicolumn{2}{|c|}{ Utilization of $\mathrm{Zn}_{\mathrm{tot}}, \%$} & \multicolumn{2}{|c|}{ Utilization of $\mathrm{Zn}_{p y}+\mathrm{Zn}_{\mathrm{ox}}, \%$} \\
\hline & & Mean & Range & Mean & Range \\
\hline Clay & 25 & $1.3^{\mathrm{b}}$ & $0.6-2.5$ & 23.1 & $6.6-36.2$ \\
\hline Silt, loam, very fine sand & 20 & $1.6^{b}$ & $0.7-3.7$ & 25.5 & $14.6-39.4$ \\
\hline Fine sand, moraine & 27 & $3.3^{\mathrm{t}}$ & $0.8-8.6$ & 24.5 & $6.4-48.6$ \\
\hline Mull & 14 & $5.1^{\mathrm{b}}$ & $2.3-10.0$ & 28.4 & $12.1-49.6$ \\
\hline Peat & 20 & $15.1^{\mathrm{a}}$ & $3.7-40.3$ & 33.1 & $6.8-68.8$ \\
\hline
\end{tabular}

'Means in each column were tested separately.

range $0.6-40.3 \%$ ). It was greater in the peat soils as compared to the other soils (Table 34). In organogenic soils there was a correlation $\left(r=0.80^{* * * *}\right)$ between organic $\mathrm{C}$ and utilization of $\mathrm{Zn}_{\text {tot }}$, which is explained by the inverse relationship between organic $\mathrm{C}$ and $\mathrm{Zn}_{\text {tot. }}$. In five out of 20 peat soils $\mathrm{Zn}$ uptake exceeded $20 \%$ of $\mathrm{Zn}_{\text {tot. }}$. In mineral soils, decreasing $\mathrm{pH}$ promoted the utilization of $\mathrm{Zn}_{\text {tot }}(\mathrm{r}=$ $\left.0.42^{* * *}\right)$, and clay content correlated negatively with the relative utilization of $\mathrm{Zn}_{\text {tot }}\left(\mathrm{r}=-0.51^{* * *}\right)$. This is because clay content correlated with $\mathrm{Zn}_{\text {tot }}$, but $\mathrm{Zn}$ in the fine-textured mineral soils was to a higher extent in the residual fraction unavailable to plants.

In the short term, secondary $\mathrm{Zn}$ fractions serve as the reserve of plant-available $\mathrm{Zn}$ in soil. Therefore, rather than utilization of $\mathrm{Zn}_{\text {tot }}$, it is more appropri- ate to investigate the use of secondary $\mathrm{Zn}$ reserves. Relative utilization of secondary $\mathrm{Zn}$ in soil is affected by the size of the reserves as well as by their availability. For example, a given $\mathrm{Zn}$ uptake by the crop corresponds to a stronger relative utilization of $\mathrm{Zn}$ in a soil which has small reserves as compared to another soil which contains more $\mathrm{Zn}$ in a plantavailable form. Strong relative utilization of soil $\mathrm{Zn}$ may reflect the tendency of those reserves to be exhausted by plant uptake. Zinc uptake by ryegrass corresponded on average to $109 \%$ of $\mathrm{Zn}_{\text {ex }}$ and ranged $15-535 \%$. This result suggests that in addition to the water-soluble and exchangeable fraction, also less soluble $\mathrm{Zn}$ must have been taken up in several soils. Therefore the emphasis of studies on the relative utilization of soil $\mathrm{Zn}$ was in the $\mathrm{Zn}_{\text {py }}$ and $\mathrm{Zn}_{\mathrm{ox}}$ fractions. 
The relative utilization of secondary $\mathrm{Zn}$ was calculated as the ratio of $\mathrm{Zn}$ uptake $\left(\mathrm{mg} \mathrm{dm}^{-3}\right)$ to the sum $\mathrm{Zn}_{\text {py }}+\mathrm{Zn}_{\text {ox }}\left(\mathrm{mg} \mathrm{dm} \mathrm{dm}^{-3}\right)$, i.e. $100 \cdot \mathrm{Zn}$ uptake $/\left(\mathrm{Zn}_{\text {py }}+\mathrm{Zn}_{\text {ox }}\right)$. Because the uptake of $\mathrm{Zn}$ in a pot experiment was used in the calculation of this index, the validity of the numerical values obtained is limited to this particular experiment. Zinc uptake amounted to $27.3 \%$ of $\mathrm{Zn}_{\text {py }}+\mathrm{Zn}_{\text {ox }}$, the range from $1.8 \%$ in soil 71 to $68.8 \%$ in peat soil 97 (Table 34 ). The secondary $\mathrm{Zn}$ fractions were utilized on average slightly more effectively in peat soils than in mineral soils, but the differences were not statistically significant. In 11 soils (two coarse mineral soils, two mull soils, seven peat soils) poor in $\mathrm{Zn}$ the relative utilization of secondary $\mathrm{Zn}$ reserves exceeded $40 \%$.

Because correlation and regression analyses did not describe accurately the relationships between different soil characteristics and the relative utilization of secondary $\mathrm{Zn}$, the quartiles of this index were investigated. The quartiles were designated I IV according to increasing relative utilization of secondary $\mathrm{Zn}$ (Table 35). Coarse mineral soils were evenly distributed but in several clay soils $\mathrm{Zn}$ reserves tended to be poorly utilized, while in several organogenic soils strong relative utilization was observed.

The quartiles of relative utilization of secondary $\mathrm{Zn}$ were compared to those of $\mathrm{Zn}$ uptake. There were soils of all possible combinations of these two dimensions (Table 36). Large reserves of soil $\mathrm{Zn}$ were in most soils connected to a weak relative utilization, but small reserves were not necessarily effectively utilized by the grass. The four extreme groups of soils, shaded in the corners of Table 36, were studied in more detail. These soils were supposed to possess outstanding characteristics connected to given patterns of utilization of soil $\mathrm{Zn}$. The rest of the soils were supposed to have the same characteristics less illustratively. The four extreme groups of soils were as follows:

Group 1: combination of high $\mathrm{Zn}$ uptake (1720 $6190 \mu \mathrm{g} \mathrm{dm}^{-3}$ ) (quartile I) and weak relative utilization of secondary $\mathrm{Zn}$ (quartile I). The group consisted of 12 soils of large $\mathrm{Zn}$ reserves. All the seven soils containing more than $10 \mathrm{mg} \mathrm{Zn}_{\mathrm{Ac}} \mathrm{dm}^{-3}$ occurred in this group. Soil $\mathrm{pH}(5.3-7.2)$ was of
Table 35. Distribution of soils of different classes into quartiles $\left(\mathrm{F}_{25 \mathrm{~s}_{0}}\right)$ of relative utilization of secondary $\mathrm{Zn}$ reserves $\left(\mathrm{Zn}_{\mathrm{py}}+\mathrm{Zn}_{\mathrm{ox}}\right)$. The quartiles are designated I-IV according to increasing relative utilization of secondary $\mathrm{Zn}$ of soil.

\begin{tabular}{lcrcc}
\hline Quartile & $\begin{array}{c}\text { Relative } \\
\text { utilization } \\
\text { of } \begin{array}{c}\mathrm{Zn}_{\mathrm{py}}+\mathrm{Zn}_{\text {ox }}, \\
\%\end{array}\end{array}$ & $\begin{array}{c}\text { Clay } \\
\text { soils }\end{array}$ & $\begin{array}{c}\text { Coarse } \\
\text { mineral } \\
\text { soils }\end{array}$ & $\begin{array}{c}\text { Organo- } \\
\text { genic } \\
\text { soils }\end{array}$ \\
\hline I & $1.8-19.5$ & 6 & 13 & 8 \\
II & $19.6-25.5$ & 11 & 9 & 7 \\
III & $25.7-30.9$ & 5 & 16 & 6 \\
IV & $31.2-68.8$ & 3 & 10 & 13 \\
\hline
\end{tabular}

Table 36. Distribution of soils into quartiles $\left(\mathrm{F}_{25 \%}\right)$ of $\mathrm{Zn}$ uptake by ryegrass and into quartiles of relative utilization of secondary $\mathrm{Zn}\left(\mathrm{Zn}_{\mathrm{py}}+\mathrm{Zn}_{\mathrm{ox}}\right)$ of soil.

\begin{tabular}{lrccr}
\hline $\begin{array}{l}\text { Quartile of relative } \\
\text { utilization of } \\
\text { secondary } \mathrm{Zn}^{1}\end{array}$ & \multicolumn{4}{c}{ Quartile of $\mathrm{Zn}$ uptake } \\
\cline { 2 - 5 } & I & II & III & IV \\
\hline I & 12 & 7 & 3 & 5 \\
II & 7 & 7 & 9 & 3 \\
III & 6 & 7 & 4 & 11 \\
IV & 2 & 6 & 10 & 8 \\
\hline
\end{tabular}

1 The quartiles are designated I-IV according to increasing relative utilization of secondary $\mathrm{Zn}$ of soil.

2 The quartiles are designated I-IV according to the decreasing Zn uptake

minor importance in these soils with excessive reserves of plant-available $\mathrm{Zn}$.

Group 2: high $\mathrm{Zn}$ uptake (quartile I) and strong relative utilization (39\%) of secondary $\mathrm{Zn}$ (quartile IV). The group contained only one very fine sand (40) and one peat soil (99). These soils were acid (pH4.2 and 5.5) and the $\mathrm{Zn}_{\mathrm{Ac}}\left(2.9\right.$ and $3.5 \mathrm{mg} \mathrm{dm}^{-3}$ ) was around the median of the material. These soils are examples of rapid reduction of $\mathrm{Zn}$ reserves which were at least average in size. Owing to a small number of soils, this group was improperly portrayed.

Group 3: strong relative utilization of soil $\mathrm{Zn}$ (quartile IV) and low $\mathrm{Zn}$ uptake by plants (quartile IV). This group consisted of one gyttja clay (soil $12)$, three fine sands $(50,51$ and 66$)$ and four or- 
Table 37. Soils showing a small $\mathrm{Zn}$ supply to ryegrass and strong relative utilization of secondary $\mathrm{Zn}$ reserves (group 3 ).

\begin{tabular}{lcccccc}
\hline Soil & $\begin{array}{c}\text { Org. C } \\
\%\end{array}$ & $\mathrm{pH}$ & $\begin{array}{c}\mathrm{Zn}_{\mathrm{Ac}} \\
\mathrm{mg} \mathrm{dm}\end{array}$ & $\begin{array}{c}\mathrm{Zn}_{\mathrm{py}}+\mathrm{Zn}_{\text {ox }} \\
\mathrm{mg} \mathrm{dm}^{-3}\end{array}$ & $\begin{array}{c}\mathrm{Zn} \text { uptake } \\
\mu \mathrm{g} \mathrm{dm} \mathrm{dm}^{-3}\end{array}$ & $\begin{array}{c}\text { Utilization } \\
\text { of } \mathrm{Zn}_{\mathrm{py}}+\mathrm{Zn}_{\mathrm{ox}}, \%\end{array}$ \\
\hline 12 & 9.5 & 5.4 & 1.5 & 2.9 & 950 & 33 \\
50 & 1.3 & 6.3 & 2.1 & 3.8 & 1170 & 31 \\
51 & 2.4 & 6.4 & 1.7 & 3.4 & 1060 & 31 \\
66 & 6.1 & 5.4 & 1.3 & 2.2 & 1070 & 49 \\
83 & 21.5 & 5.6 & 0.8 & 1.6 & 790 & 50 \\
97 & 38.8 & 5.5 & 1.8 & 0.9 & 620 & 69 \\
98 & 39.8 & 4.9 & 1.5 & 2.1 & 940 & 65 \\
103 & 47.3 & 4.8 & 0.6 & 1.0 & 660 & 65 \\
\hline
\end{tabular}

Table 38. Soils showing a small $\mathrm{Zn}$ supply to ryegrass and low relative utilization of secondary $\mathrm{Zn}$ reserves in soil (group 4).

\begin{tabular}{lcccrrr}
\hline Soil & $\begin{array}{c}\text { Org. C } \\
\%\end{array}$ & $\mathrm{pH}$ & $\begin{array}{c}\mathrm{Zn}_{\mathrm{Ac}} \\
\mathrm{mg} \mathrm{dm}^{-3}\end{array}$ & $\begin{array}{c}\mathrm{Zn}_{\mathrm{py}}+\mathrm{Zn}_{\text {ox }} \\
\mathrm{mg} \mathrm{dm}^{-3}\end{array}$ & $\begin{array}{r}\mathrm{Zn} \mathrm{uptake} \\
\mu \mathrm{dm}^{-3}\end{array}$ & $\begin{array}{c}\text { Utilization } \\
\text { of } \mathrm{Zn}_{\mathrm{py}}+\mathrm{Zn}_{\mathrm{ox}}, \%\end{array}$ \\
\hline 21 & 3.2 & 6.4 & 2.3 & 7.6 & 1020 & 13 \\
28 & 0.8 & 6.6 & 0.8 & 4.5 & 760 & 17 \\
38 & 4.8 & 6.4 & 1.4 & 6.6 & 1070 & 16 \\
69 & 1.5 & 7.4 & 2.7 & 7.2 & 690 & 10 \\
\hline
\end{tabular}

ganogenic soils $(83,97,98,103)$ (Table 37). These soils, except soil 50 , belonged to the smallest quartile of $\mathrm{Zn}_{\text {Ac. }}$. The four organogenic soils were even within the $\mathrm{F}_{10 \%}$ of strongest relative utilization of secondary $\mathrm{Zn}$ as well as in the smallest $\mathrm{F}_{10 \%}$ of $\mathrm{Zn}$ uptake. Zinc uptake in these soils was thus limited by the small reserves.

Group 4: low $\mathrm{Zn}$ uptake (quartile IV) connected with weak relative utilization of soil $\mathrm{Zn}$ (quartile I). In the four mineral soils of this group (Table 38) soil pH was distinctly higher, and $\mathrm{Zn}_{\text {tot }}, \mathrm{Zn}_{\text {py }}+\mathrm{Zn}_{\text {ox }}$, and $\mathrm{Zn}_{\mathrm{Ac}}$ were higher than in group 3, but $\mathrm{Zn}_{\mathrm{Ac}}$ was below the median of the material $\left(2.9 \mathrm{mg} \mathrm{dm}^{-3}\right)$. Zinc uptake by the grass was thus limited by relatively small reserves of $\mathrm{Zn}$ which, owing to a rather high $\mathrm{pH}$, were poorly available.

In groups 3 (low uptake, strong relative utilization of secondary $\mathrm{Zn}$ ) and 1 (high uptake, weak relative utilization) the soils had the most distinctive characteristics. Also some characteristics of the combination of weak relative utilization and low $\mathrm{Zn}$ uptake (group 4) could be defined. Groups 3 and 4 exhibited two different combinations of characteristics resulting in a limited $\mathrm{Zn}$ supply to plants. Group 3 contained soils with small $\mathrm{Zn}$ reserves which, owing to the strong acidity, had a high availability to plants, resulting in a strong relative utilization. In turn, the soils of group 4 had larger $\mathrm{Zn}$ reserves which, owing to a higher $\mathrm{pH}$, showed a poorer availability resulting in a weak relative utilization of these reserves. These conclusions are supported by the different patterns of $\mathrm{Zn}$ concentrations of grass grown in the organogenic soils of group 3 and in the mineral soils of group 4 (Figure $5)$. In the organogenic soils of group 3 , the $\mathrm{Zn}$ concentration of grass decreased from crop to crop, suggesting declining reserves of plant-available $\mathrm{Zn}$ in soil. In group 4 , the $\mathrm{Zn}$ concentration of plants increased during the experiment, suggesting increased availability, probably owing to acidification of the soil in the course of the experiment. 

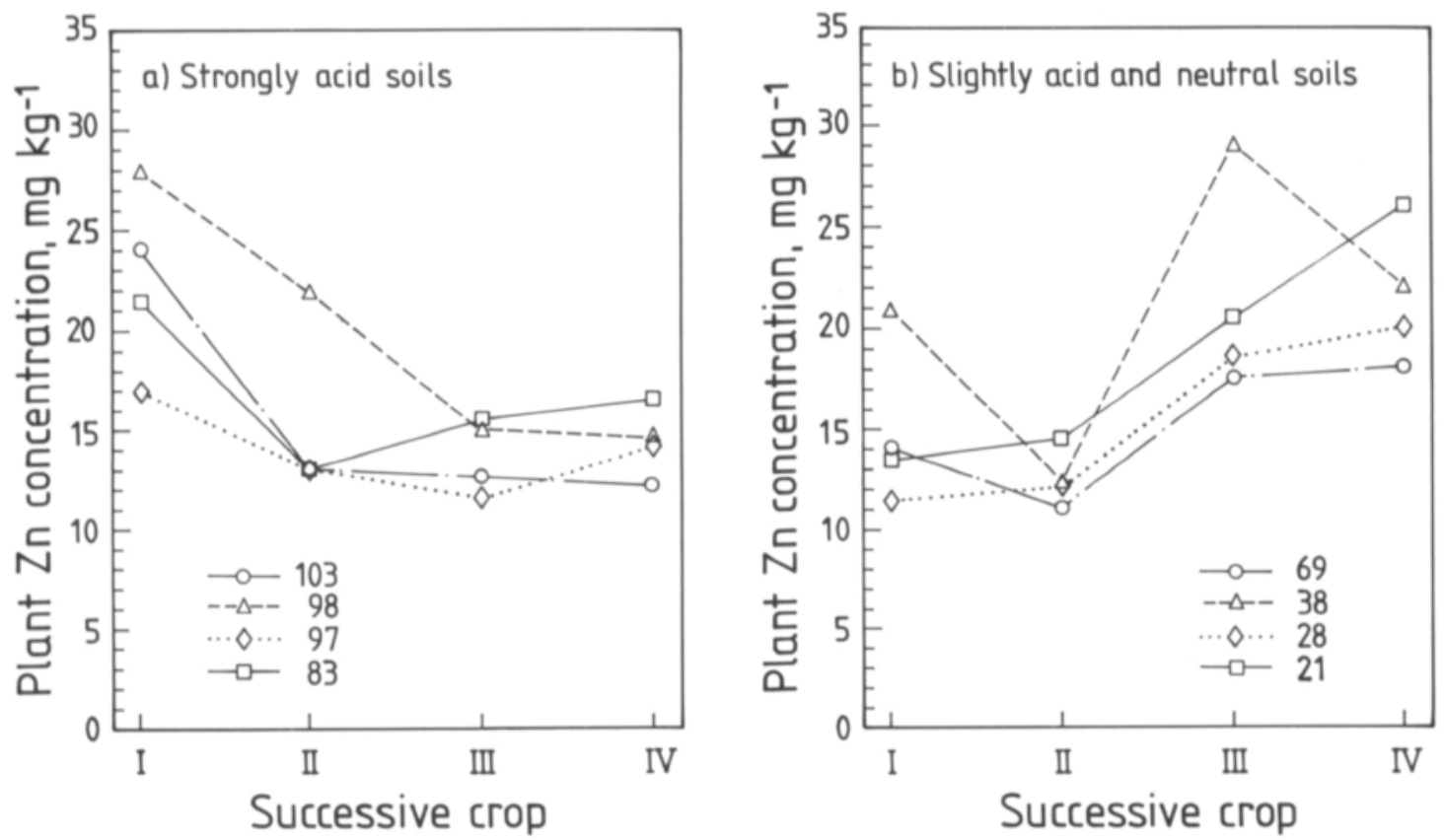

Fig. 5. Zinc concentration of four ryegrass crops grown (a) in very acid peat soils (group 3) where a strong relative utilization of secondary soil $\mathrm{Zn}$ was measured and (b) in slightly acid and neutral mineral soils (group 4) where a weaker relative utilization of secondary soil $\mathrm{Zn}$ occurred.

\subsection{Effect of $\mathrm{Zn}$ application on plant $\mathrm{Zn}$ concentration}

\subsubsection{Experimental}

A pot experiment was carried out in order to study the relationships between soil characteristics and the effect of $\mathrm{Zn}$ application on $\mathrm{Zn}$ concentration of ryegrass. The experiment was carried out in the same way as the one presented earlier (Section 4.1) with the exception that the pots were not limed. Zinc ( $10 \mathrm{mg} \mathrm{dm}^{-3}$ of soil) was applied as a solution of $\mathrm{ZnSO}_{4}$. One crop of Italian ryegrass was grown for 30 days in polythene boxes containing $0.2 \mathrm{dm}^{3}$ of soil. There were two pots of each soil to which $\mathrm{Zn}$ was applied; two pots were grown without added $\mathrm{Zn}$. Of the 107 surface soils (Appendix 2), 101 soils were available for this trial. Those not available $(15,27,29,51,88,107)$ were of average characteristics.

\subsubsection{Dry matter yields and plant $\mathrm{Zn}$ concentrations}

The average dry matter production was $3.23 \mathrm{~g}$ per pot; the highest yields were nearly double the lowest ones (Table 39). The mean deviation of dry matter yield between the two replicates was $0.10 \mathrm{~g}$ per pot, or $3.1 \%$ of the average yield. The yields grown without added $\mathrm{Zn}$ correlated closely ( $\mathrm{r}=$ $0.88^{* * * *}$ ) with the yields fertilized with $\mathrm{Zn}$. According to the paired t-test, $\mathrm{Zn}$ application did not affect the size of the yield in any of the soil classes. The yields were not increased by $\mathrm{Zn}$ application even in soils producing grass with the lowest $\mathrm{Zn}$ concentration.

The mean deviation of $\mathrm{Zn}$ concentration between the two replicates was $1.6 \mathrm{mg} \mathrm{kg}^{-1}$ and $1.0 \mathrm{mg} \mathrm{kg}^{-1}$ in pots grown with and without applied $\mathrm{Zn}$, corresponding to $4.5 \%$ of the mean in both treatments. The average $\mathrm{Zn}$ concentration of grass grown in mineral soils without applied $\mathrm{Zn}\left(19.5 \mathrm{mg} \mathrm{kg}^{-1}\right)$ was 
Table 39. Dry matter yields, $\mathrm{Zn}$ concentration and $\mathrm{Zn}$ uptake of ryegrass in a pot experiment. $\mathrm{Zn}-=$ no $\mathrm{Zn}$ applied, $\mathrm{Zn}+=\mathrm{Zn}$ applied.

\begin{tabular}{|c|c|c|c|c|c|c|}
\hline \multirow[t]{2}{*}{ Soil class } & & \multicolumn{2}{|c|}{$\begin{array}{l}\text { Dry matter } \\
\text { g per pot }\end{array}$} & \multicolumn{2}{|c|}{$\begin{array}{l}\mathrm{Zn} \text { concentration } \\
\mathrm{mg} \mathrm{kg}{ }^{-1}\end{array}$} & \multirow{2}{*}{$\begin{array}{c}\begin{array}{c}\text { Zn uptake } \\
\mu \mathrm{g} \mathrm{dm}^{-3}\end{array} \\
\text { Mean }^{2}\end{array}$} \\
\hline & & Mean' & Range & Mean $^{2}$ & Range & \\
\hline $\begin{array}{l}\text { Clay } \\
\mathrm{n}=25\end{array}$ & $\begin{array}{l}\mathrm{Zn}- \\
\mathrm{Zn}+\end{array}$ & $\begin{array}{l}3.32^{\mathrm{a}} \\
3.34^{\mathrm{a}}\end{array}$ & $\begin{array}{l}2.79-3.86 \\
2.12-3.77\end{array}$ & $\begin{array}{l}21.8^{\text {de }} \\
32.5^{\text {b }}\end{array}$ & $\begin{array}{l}11.5-35.0 \\
19.0-53.0\end{array}$ & $\begin{array}{l}360^{\mathrm{cd}} \\
530^{\mathrm{ab}}\end{array}$ \\
\hline $\begin{array}{l}\text { Silt, loam, very } \\
\text { fine sand, } n=18\end{array}$ & $\begin{array}{l}\mathrm{Zn}- \\
\mathrm{Zn}+\end{array}$ & $\begin{array}{l}3.41^{\mathrm{a}} \\
3.48^{\mathrm{a}}\end{array}$ & $\begin{array}{l}2.67-4.20 \\
2.85-4.14\end{array}$ & $\begin{array}{l}18.7^{\mathrm{de}} \\
34.9^{\mathrm{ab}}\end{array}$ & $\begin{array}{l}10.5-29.5 \\
25.0-63.0\end{array}$ & $\begin{array}{l}310^{\mathrm{cd}} \\
600^{\mathrm{ab}}\end{array}$ \\
\hline $\begin{array}{l}\text { Fine sand, moraine } \\
\mathrm{n}=26\end{array}$ & $\begin{array}{l}\mathrm{Zn}- \\
\mathrm{Zn}+\end{array}$ & $\begin{array}{l}3.11^{\mathrm{ab}} \\
3.10^{\mathrm{ab}}\end{array}$ & $\begin{array}{l}2.14-3.59 \\
1.76-3.80\end{array}$ & $\begin{array}{l}18.3^{\mathrm{e}} \\
33.0^{\mathrm{b}}\end{array}$ & $\begin{array}{r}7.5-38.0 \\
13.5-81.5\end{array}$ & $\begin{array}{l}280^{\mathrm{d}} \\
500^{\mathrm{b}}\end{array}$ \\
\hline $\begin{array}{l}\text { Mull } \\
\mathrm{n}=13\end{array}$ & $\begin{array}{l}\mathrm{Zn}- \\
\mathrm{Zn}+\end{array}$ & $\begin{array}{l}2.91^{\mathrm{b}} \\
3.06^{\mathrm{b}}\end{array}$ & $\begin{array}{l}2.46-3.63 \\
2.35-3.83\end{array}$ & $\begin{array}{l}25.5^{\mathrm{cd}} \\
39.0^{\mathrm{ab}}\end{array}$ & $\begin{array}{l}18.5-33.5 \\
31.0-48.5\end{array}$ & $\begin{array}{l}360^{\mathrm{cd}} \\
590^{\mathrm{ab}}\end{array}$ \\
\hline $\begin{array}{l}\text { Peat } \\
\mathrm{n}=18\end{array}$ & $\begin{array}{l}\mathrm{Zn}- \\
\mathrm{Zn}+\end{array}$ & $\begin{array}{l}2.89^{\mathrm{b}} \\
2.88^{\mathrm{b}}\end{array}$ & $\begin{array}{l}1.86-3.77 \\
1.99-3.77\end{array}$ & $\begin{array}{l}28.4^{\mathrm{c}} \\
44.3^{\mathrm{a}}\end{array}$ & $\begin{array}{r}9.0-55.0 \\
21.0-62.0\end{array}$ & $\begin{array}{l}410^{c} \\
630^{a}\end{array}$ \\
\hline
\end{tabular}

1 All means in the column were tested simultaneously.

${ }^{2}$ Means of $\mathrm{Zn}$ - (superscripts c, d and e) and $\mathrm{Zn}+$ (superscripts a and b) were tested separately.

Table 40. Increase of $\mathrm{Zn}$ concentration upon application of $\mathrm{Zn}$ and utilization of added $\mathrm{Zn}$. $^{1}$

\begin{tabular}{lcccccc}
\hline Soil class & $\mathrm{n}$ & \multicolumn{2}{c}{ Increase of Zn concentration, mg kg-1 } & & \multicolumn{2}{c}{ Utilization of added Zn, \% } \\
\cline { 3 - 3 } & & Mean & Range & & Mean & Range \\
\hline Clay & 25 & 10.8 & $1-30$ & & $1.7^{\mathrm{b}}$ & $0.5-4.8$ \\
Silt, loam, very fine sand & 18 & 16.3 & $6-35$ & & $2.9^{\mathrm{a}}$ & $1.7-4.2$ \\
Fine sand, moraine & 26 & 14.5 & $4-53$ & & $2.1^{\text {ab }}$ & $0.8-4.5$ \\
Mull & 13 & 13.4 & $2-24.5$ & & $2.3^{\text {ab }}$ & $0.3-3.9$ \\
Peat & 18 & 15.8 & $4.5-28.5$ & & $2.2^{\text {ab }}$ & $-0.4-4.0$ \\
\hline
\end{tabular}

${ }^{1}$ Means in the two columns were tested separately.

lower $\left(\mathrm{t}=4.072^{* * *}\right)$ than that in the corresponding organogenic soils $\left(27.1 \mathrm{mg} \mathrm{kg}^{-1}\right)$. In all soil classes, $\mathrm{Zn}$ application elevated $\mathrm{Zn}$ concentration of ryegrass significantly (t-values of the paired $t-$ test not presented). The $\mathrm{Zn}$ concentration of the grass fertilized with $\mathrm{Zn}$ was lower $\left(\mathrm{t}=3.276^{* * *}\right)$ in mineral soils $\left(34.0 \mathrm{mg} \mathrm{kg}^{-1}\right)$ than in organogenic soils $\left(42.1 \mathrm{mg} \mathrm{kg}^{-1}\right)$. Zinc uptake correlated closely with the $\mathrm{Zn}$ concentration of the grass $\left(\mathrm{r}=0.84^{* * * *}\right.$ and $r=0.93^{* * *}$ in pots grown with and without $\mathrm{Zn}$ application, respectively), but there was no correlation between plant $\mathrm{Zn}$ concentration and dry matter yield.

\subsubsection{Influence of soil characteristics on the response to applied $\mathrm{Zn}$}

The average increase of $\mathrm{Zn}$ concentration caused by $\mathrm{Zn}$ application did not differ statistically from one soil class to another (Table 40), and the utilization of added $\mathrm{Zn}$ by the grass was low in all soil classes. The increase $\left(\mathrm{mg} \mathrm{kg}^{-1}\right)$ in $\mathrm{Zn}$ concentration of grass correlated slightly negatively with the dry matter yield $\left(r=0.44^{* * *}\right)$, showing that the $\mathrm{Zn}$ concentration of a smaller yield was more strongly increased than that of a larger one. In soils where grass of low $\mathrm{Zn}$ concentration was produced without added $\mathrm{Zn}$, 


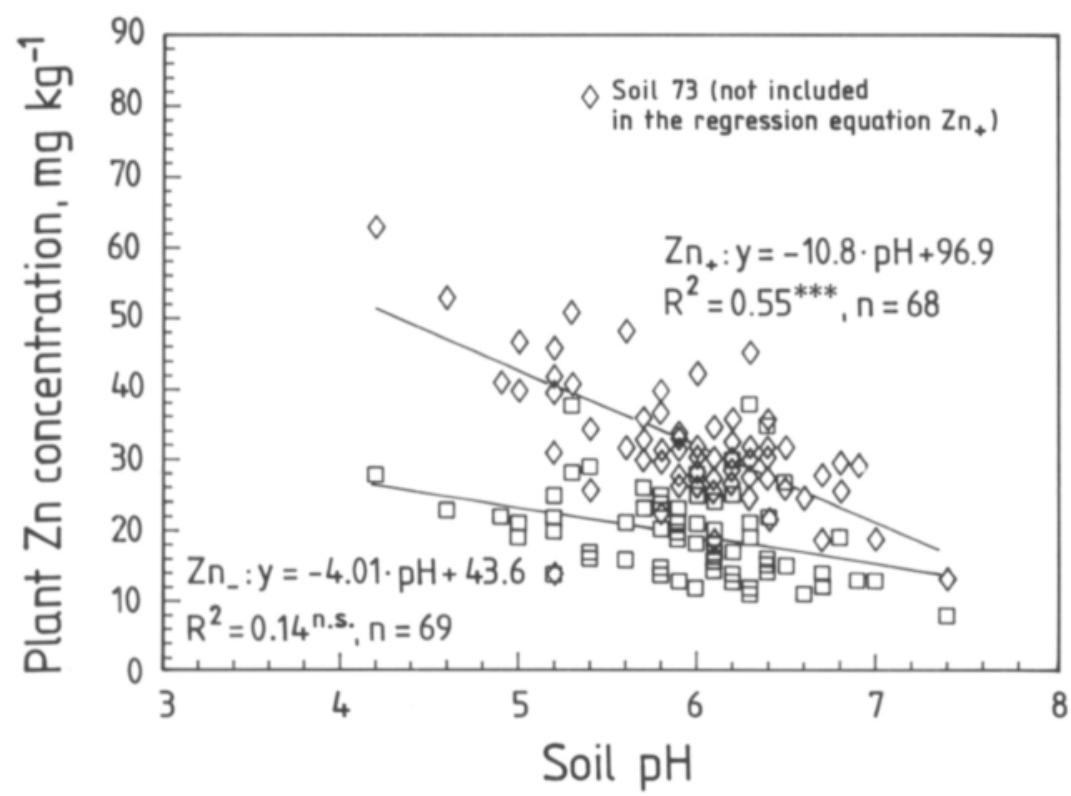

Fig. 6. Dependence of $\mathrm{Zn}$ concentration of ryegrass on soil $\mathrm{pH}$ in mineral soils fertilized with $10 \mathrm{mg} \mathrm{Zn} \mathrm{dm}^{-3}\left(\mathrm{Zn}_{+}\right.$, symbol $\left.\diamond\right)$ and those not fertilized with $\mathrm{Zn}(\mathrm{Zn}$., symbol $\square)$.

a high response to applied $\mathrm{Zn}$ was not necessarily measured, and even in soils producing grass of high $\mathrm{Zn}$ concentration a large response to applied $\mathrm{Zn}$ was occasionally observed. This resulted in a nonexistent correlation $\left(r=-0.06^{\text {n.s. }}\right)$ between $\mathrm{Zn}$ concentration of grass grown without applied $\mathrm{Zn}$ and the increase of $\mathrm{Zn}$ concentration.

It can be seen in Figure 6 that in soils fertilized with $\mathrm{Zn}$, soil $\mathrm{pH}$ had a more marked impact on plant $\mathrm{Zn}$ concentration as compared to soils not fertilized with $\mathrm{Zn}$. In neutral and slightly acid soils the effect of added $\mathrm{Zn}$ on plant $\mathrm{Zn}$ concentration was much smaller than in the more acid soils. The relationship between soil properties and response of plant $\mathrm{Zn}$ concentration to applied $\mathrm{Zn}$ in mineral soils was studied in more detail by multiple regression analyses. The results of soils 71 and 73 were not included in the tabulation, because soil 71 had an excessive $\mathrm{Zn}_{\mathrm{Ac}}$ concentration and in soil 73 the increase of plant $\mathrm{Zn}$ concentration $\left(+53 \mathrm{mg} \mathrm{kg}^{-1}\right.$ ) was much higher than in any other soil. The effect of added $\mathrm{Zn}$ on plant $\mathrm{Zn}$ concentration $\left(\mathrm{y}, \mathrm{mg} \mathrm{kg}^{-1}\right.$ ) decreased upon increasing soil $\mathrm{pH}$ which, according to the beta coefficients (Table 41), was rela- tively the most important independent variable. The equations below show that the increase of plant $\mathrm{Zn}$ concentration due to $\mathrm{Zn}$ application diminished with increasing soil $\mathrm{pH}$ at any level of native soil $\mathrm{Zn}_{\mathrm{Ac}}\left(\mathrm{mg} \mathrm{dm}^{-3}\right)$ or $\mathrm{Zn}_{\mathrm{py}}\left(\mathrm{mg} \mathrm{dm}^{-3}\right)$. On the other hand, at any $\mathrm{pH}$ the response was the greater the lower was the native $\mathrm{Zn}_{\mathrm{Ac}}$ or $\mathrm{Zn}_{\text {py }}$ in soil. Also the clay and organic $\mathrm{C}$ content (\%) had a slightly negative effect on the response. The regression equations for mineral soils $(n=68)$ were as follows:

$$
\begin{aligned}
& \mathrm{y}=-7.58 \mathrm{pH}-0.070 \text { Clay }-4.45 \log _{\mathrm{e}} \mathrm{Zn}_{\mathrm{py}}+66.06 \\
& \mathrm{R}^{2}=0.59^{* * *} \quad \text { (Equation 1) } \\
& \mathrm{y}=-8.23 \mathrm{pH}-0.77 \mathrm{C}-3.95 \log _{\mathrm{e}} \mathrm{Zn}_{\mathrm{Ac}}+68.52 \\
& \mathrm{R}^{2}=0.54^{* * *}
\end{aligned}
$$

In organogenic soils the relationship between soil $\mathrm{pH}$ and plant $\mathrm{Zn}$ concentration was inconsistent. As a matter of fact, the grass of the lowest $\mathrm{Zn}$ concentration was produced in the two most acid organogenic soils (100, pH 3.8; 105, pH 4.1), which is a striking difference from mineral soils where acidity enhanced $\mathrm{Zn}$ uptake by the grass. In the two 
Table 41. t-Values of regression coefficients and beta coefficients $(\beta)$ of independent variables in the regression equations explaining the variation of increase in $\mathrm{Zn}$ concentration upon $\mathrm{Zn}$ addition. Equation 1 and Equation 2: see text.

\begin{tabular}{lccrrr}
\hline \multirow{2}{*}{$\begin{array}{l}\text { Independent } \\
\text { variable }\end{array}$} & \multicolumn{2}{c}{ Equation 1 } & & \multicolumn{2}{c}{ Equation 2 } \\
\cline { 2 - 3 } \cline { 5 - 6 } & $\mathrm{t}$ & $\beta$ & & $\mathrm{t}$ & $\beta$ \\
\hline $\mathrm{pH}$ & $-8.374^{* * *}$ & -0.69 & & $-7.694^{* *}$ & -0.74 \\
$\mathrm{Clay}$ & $-2.929^{* *}$ & -0.24 & & - & - \\
$\log _{\mathrm{e}} \mathrm{Zn}_{\mathrm{py}}$ & $-5.329^{* * *}$ & -0.44 & & - & - \\
$\log _{\mathrm{e}} \mathrm{Zn}_{\mathrm{Ac}}$ & - & - & & $-4.699^{* *}$ & -0.41 \\
Organic C & - & - & -1.929 & -0.19 \\
\hline
\end{tabular}

' Significant at $\mathrm{P}=0.058$.

peat soils 100 and 105 , the $\mathrm{Zn}$ concentrations of the grass not fertilized with $\mathrm{Zn}$ were as low as 11 and 9 $\mathrm{mg} \mathrm{kg}^{-1}$, respectively, and no higher than $21 \mathrm{mg}$ $\mathrm{kg}^{-1}$ in grass fertilized with $\mathrm{Zn}$. In organogenic soils the increase $\left(\mathrm{mg} \mathrm{kg}^{-1}\right)$ of plant $\mathrm{Zn}$ concentration was not explained by other soil properties, either. Instead, the response was dependent on the relative utilization (\%) of native $\mathrm{Zn}_{\text {py }}$ in the pot experiment $\left(100 \cdot \mathrm{Zn}\right.$-uptake/Zn $\mathrm{Zn}_{\text {py }}$ (Figure 7). In other words,

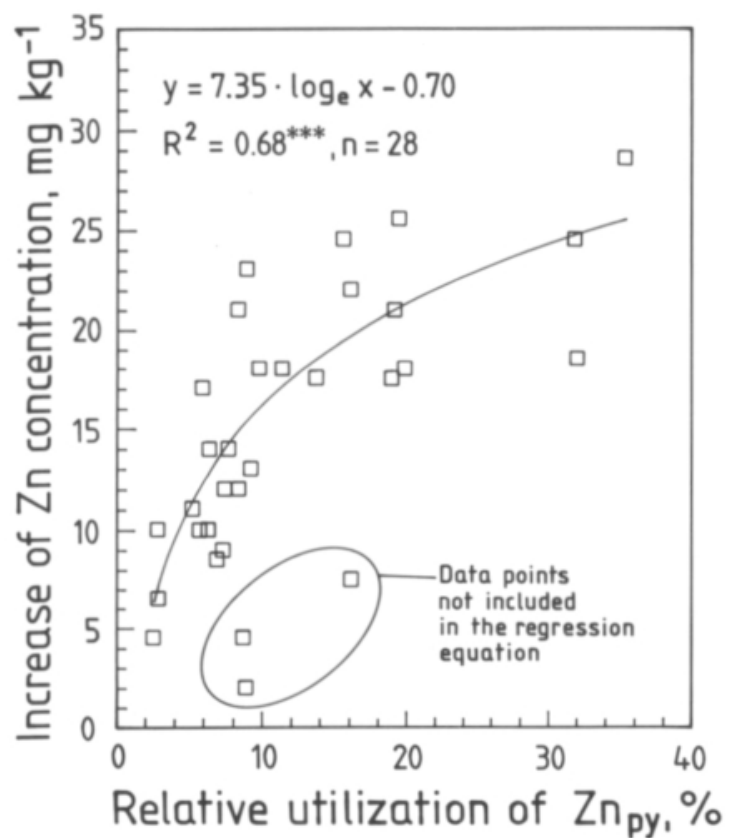

Fig. 7. Relationship between relative utilization (\%) of $\mathrm{Zn}$ extracted by pyrophosphate $\left(\mathrm{Zn}_{\mathrm{py}}\right)$ and increase of $\mathrm{Zn}$ concentration of ryegrass upon application of $10 \mathrm{mg} \mathrm{Zn} \mathrm{dm}^{-3}$ in 34 organogenic soils. grass grown in soils where native $\mathrm{Zn}_{\text {py }}$ was easily available and strongly utilized responded strongly to added $\mathrm{Zn}$ and vice versa. The grass grown in three soils $(77,87$ and 101$)$ responded to added $\mathrm{Zn}$ markedly less than would be expected on the basis of the relative utilization of $\mathrm{Zn}_{\text {py }}$. In soils 77 and 101 , the deviation between the replicates was large, possibly contributing to the inconsistent results; soil 87 was rich in clay (69\%), possibly reducing the availability of added $\mathrm{Zn}$. Omission of the three soils increased the coefficient of determination $\left(\mathrm{R}^{2}\right)$ from 0.48 to 0.68 .

\subsubsection{Response of ryegrass to applied $\mathrm{Zn}$ in soils poor in $\mathbf{Z n}_{\text {Ac }}$}

The need for $\mathrm{Zn}$ fertilization is in Finland currently assessed on the basis of soil $\mathrm{Zn}_{\text {Ac. }}$. It is assumed that the need for $\mathrm{Zn}$ fertilization of a soil is the greater the less $\mathrm{Zn}_{\mathrm{Ac}}$ is extracted from the soil. It might further be presumed that the greatest responses in plant $\mathrm{Zn}$ concentration would occur in soils poorest in $\mathrm{Zn}_{\mathrm{Ac}}$. According to the previous regression analyses, a decrease in $\mathrm{Zn}_{\mathrm{Ac}}$ indeed enhanced the response of plant $\mathrm{Zn}$ concentration to added $\mathrm{Zn}$, but the regression equations did not accurately explain the variation of the response. Therefore the increases of $\mathrm{Zn}$ concentration were divided into quartiles $\left(\mathrm{F}_{25} \%\right)$ which were compared with the quartiles of soil $\mathrm{Zn}_{\mathrm{Ac}}$. Because, according to the present recommendations, $\mathrm{Zn}$ fertilization is most commonly applied to soils poorest in $\mathrm{Zn}_{\mathrm{Ac}}$, the effect of $\mathrm{Zn}$ application on plant $\mathrm{Zn}$ concentration grown on these soils was studied with particular care.

There were 19 mineral soils in the smallest quartile of $\mathrm{Zn}_{\mathrm{Ac}}\left(\mathrm{Zn}_{\mathrm{Ac}} \leq 1.85 \mathrm{mg} \mathrm{dm}^{-3}\right.$, Table 42). Only in three of these mineral soils was there a strong response (the largest $\mathrm{F}_{25}$ \%, quartile I) of plant $\mathrm{Zn}$ concentration to applied $\mathrm{Zn}$. In the bulk of these mineral soils the increase of plant $\mathrm{Zn}$ concentration was smaller, placing them in the second or third quartile of response, but in none of the mineral soils concerned was the increase of $\mathrm{Zn}$ concentration of the grass very small (quartile IV). Within the group of these 19 mineral soils, the increase of plant $\mathrm{Zn}$ concentration did not correlate with soil $\mathrm{Zn}_{\mathrm{Ac}}$, but 
Table 42. Soil $\mathrm{Zn}_{\mathrm{Ac}}$ and $\mathrm{pH}$ in mineral and organogenic soils poorest in $\mathrm{Zn}_{\mathrm{Ac}}\left(\mathrm{Zn}_{\mathrm{Ac}} \leq 1.85 \mathrm{mg} \mathrm{dm}^{-3}\right)$. The soils are divided into groups according to quartiles $\left(\mathrm{F}_{25 \mathrm{e}_{0}}\right)$ of the increase of $\mathrm{Zn}$ concentration of ryegrass when $10 \mathrm{mg} \mathrm{Zn} \mathrm{dm}^{-3}$ was added to the respective soil.

\begin{tabular}{|c|c|c|c|c|c|}
\hline \multirow{2}{*}{$\begin{array}{l}\text { Increase of } \mathrm{Zn} \\
\text { concentration, } \mathrm{mg} \mathrm{kg}-1\end{array}$} & \multirow[t]{2}{*}{ Soil } & \multicolumn{2}{|c|}{$\mathrm{Zn}_{\mathrm{Ac}}, \mathrm{mg} \mathrm{dm}^{-3}$} & \multicolumn{2}{|c|}{$\mathrm{pH}$} \\
\hline & & Mean & Range & Mean & Range \\
\hline \multirow{2}{*}{$\begin{array}{l}\geq 181 \\
\text { (Quartile I) }\end{array}$} & Mineral soils: & 1.3 & $0.8-1.8$ & 5.5 & $5.2-6.0$ \\
\hline & $\begin{array}{l}44,52,66 \\
\text { Organogenic soils: } \\
83,94,97,98,103\end{array}$ & 1.3 & $0.6-1.8$ & 5.2 & $4.8-5.6$ \\
\hline $\begin{array}{l}\text { 13-17.51 } \\
\text { (Quartile II) }\end{array}$ & $\begin{array}{l}\text { Mineral soils: } \\
3,13,23,28,38,45 \\
48,49,54,61,63,65\end{array}$ & 1.4 & $0.8-1.9$ & 6.3 & $5.8-6.9$ \\
\hline \multirow[t]{2}{*}{$\begin{array}{l}\text { 9-12.5' } \\
\text { (Quartile III) }\end{array}$} & $\begin{array}{l}\text { Mineral soils: } \\
12,37,41,64\end{array}$ & 1.6 & $1.5-1.9$ & 6.0 & $5.4-6.5$ \\
\hline & $\begin{array}{l}\text { Organogenic soils: } \\
105\end{array}$ & 1.6 & - & 4.1 & - \\
\hline
\end{tabular}

\section{$\leq 8.5^{1}$}

None

(Quartile IV)

' Limits of quartiles were set based on the pot experiment with 101 surface soils.

the observed response was to some extent explained by soil $\mathrm{pH}$. The three soils responding strongly to added $\mathrm{Zn}(44,52,66)$ had a pH equal to or below 6.0 , while in most of the soils in which a smaller response was observed the $\mathrm{pH}$ was commonly above 6.0 which was the average of the mineral surface soils. It should be pointed out that in the whole material $(n=101)$ the greatest increases $\left(30-53 \mathrm{mg} \mathrm{kg}^{-1}\right)$ in plant $\mathrm{Zn}$ concentration occurred in very acid ( $\mathrm{pH} 4.2$ - 5.4) mineral soils $(10,40,52,73)$ containing $1.8-3.8 \mathrm{mg} \mathrm{Zn}_{\mathrm{Ac}} \mathrm{dm}^{-3}$, and only one of these (52) was among the soils poorest in $\mathrm{Zn}_{\mathrm{Ac}}$ (within the smallest $\mathrm{F}_{25 \%}$ ). This observation further confirms that low $\mathrm{Zn}_{\mathrm{Ac}}$ does not guarantee strong response of plant $\mathrm{Zn}$ concentration to applied $\mathrm{Zn}$.

There were six organogenic soils in the smallest $\mathrm{F}_{25 \%}$ of $\mathrm{Zn}_{\mathrm{Ac}}$, all of which were very acid (Table 42). In five of those, a strong response (quartile I) of plant $\mathrm{Zn}$ concentration to applied $\mathrm{Zn}$ was measured. In all the five organogenic soils, secondary $\mathrm{Zn}$ reserves were quite effectively (the largest $\mathrm{F}_{10 \%}$ ) utilized. Thus, in organogenic soils a very low concentration of $\mathrm{Zn}_{\mathrm{Ac}}$ resulted in a large increase in plant $\mathrm{Zn}$ concentration as a consequence of $\mathrm{Zn}$ application. The only exception was the extremely acid soil 105 ( $\mathrm{pH} 4.1$ ) in which the grass responded less strongly. In this soil, the $\mathrm{pH}$ was as low as 3.8 at the end of the experiment.

\subsection{Effect of liming and different rates of $\mathrm{Zn}$ application on ryegrass}

\subsubsection{Experimental}

The effect of liming and different rates of applied $\mathrm{Zn}$ on the yield and $\mathrm{Zn}$ concentration of ryegrass was investigated on clay, fine sand, Carex peat and Sphagnum peat (Appendix 6) in a pot experiment. The Sphagnum peat was commercial light-colored peat; the other experimental soils were taken from cultivated fields. The pots (four replicates) were filled with $7.5 \mathrm{dm}^{3}$ of Sphagnum peat or $7 \mathrm{dm}^{3}$ of the other three soils. Lime was mixed into the assigned pots at the beginning of the experiment three days before the actual fertilization. In clay, fine sand and Carex peat, one rate of $\mathrm{Ca}(\mathrm{OH})_{2}$ (clay and 
fine sand: $7.0 \mathrm{~g}$ per pot, Carex peat: $14 \mathrm{~g}$ per pot) was applied to elevate soil $\mathrm{pH}$ by one unit. The Sphagnum peat was originally extremely acid $\left(\mathrm{CaCl}_{2}-\mathrm{pH} 2.8\right)$ and the grass did not grow without liming. Therefore two rates of $\mathrm{Ca}(\mathrm{OH})_{2}$ ( 16 and 23 $\mathrm{g}$ per pot) were applied to Sphagnum peat and no unlimed pots were grown.

Zinc was applied in a $\mathrm{ZnSO}_{4}$ solution to clay, fine sand and Carex peat at the rates of $0,2.7,10$, 20 and $40 \mathrm{mg} \mathrm{Zn} \mathrm{dm}^{-3}$ and to Sphagnum peat at the rates of $0,5,10,20,50$ and $100 \mathrm{mg} \mathrm{Zn} \mathrm{dm}^{-3}$. The excessive $\mathrm{Zn}$ rates were applied in order to get information on $\mathrm{Zn}$ tolerance of ryegrass. At the beginning of the experiment, the following quantities ( $\mathrm{mg} \mathrm{dm}^{-3}$ of soil) of other nutrients were mixed in the entire soil of the pot as analytical grade chemicals:

$\begin{array}{lcl}\text { Nutrient } & \text { Rate, } \mathrm{mg} \mathrm{dm}^{-3} & \text { Compound } \\ \mathrm{N} & 200 & \mathrm{NH}_{4} \mathrm{NO}_{3} \\ \mathrm{P} & 50 & \mathrm{Ca}\left(\mathrm{H}_{2} \mathrm{PO}_{4}\right)_{2} \cdot \mathrm{H}_{2} \mathrm{O} \\ \mathrm{K} & 200 & \mathrm{KCl} \\ \mathrm{Mg} & 50 & \mathrm{MgSO}_{4} \cdot 7 \mathrm{H}_{2} \mathrm{O} \\ \mathrm{S} & 68 & \text { mainly } \mathrm{MgSO}_{4} \cdot \mathrm{H}_{2} \mathrm{O} \\ \mathrm{Cu} & 2 & \mathrm{CuSO}_{4} \cdot 5 \mathrm{H}_{2} \mathrm{O} \\ \mathrm{Mn} & 2 & \mathrm{MnSO}_{4} \cdot \mathrm{H}_{2} \mathrm{O} \\ \mathrm{Fe} & 2 & \mathrm{FeSO}_{4} \cdot 7 \mathrm{H}_{2} \mathrm{O} \\ \mathrm{B} & 0.5 & \mathrm{H}_{3} \mathrm{BO}_{3} \\ \mathrm{Mo} & 0.5 & \mathrm{Na}_{2} \mathrm{MoO}_{7} \cdot \mathrm{H}_{2} \mathrm{O}\end{array}$

Ca was added to the soil at different rates depending on the liming. The macronutrients were mixed in the soil as solids and the micronutrients as solutions. The quantity of seed sown was $2.5 \mathrm{~g}$ per pot. The pots were grown in a greenhouse and watered daily with deionized water. In clay, fine sand and Carex peat, two crops were grown without reseeding. For the second crop, N, P and $\mathrm{K}$ solutions $\left(\mathrm{NH}_{4} \mathrm{NO}_{3}, \mathrm{KCl}\right.$ and $\left.\mathrm{KH}_{2} \mathrm{PO}_{4}\right)$ were pipetted onto the surface of the soil in four portions at intervals of four to five days, resulting in a total of 200 , 50 and $200 \mathrm{mg}$ of $\mathrm{N}, \mathrm{P}$ and $\mathrm{K}$ per $\mathrm{dm}^{3}$ of soil, respectively. For Sphagnum peat, the experiment continued for two years. Three crops were grown in the first summer. During the winter the pots were stored outdoors covered with plastic foil, and in the second spring fertilized and reseeded. Then, two more crops were grown in pots to which 5, 20, 50 or $100 \mathrm{mg} \mathrm{Zn} \mathrm{dm}^{-3}$ had been applied. At two rates of $\mathrm{Zn}$ application $\left(0\right.$ and $\left.10 \mathrm{mg} \mathrm{Zn} \mathrm{dm}^{-3}\right)$ five crops were grown in the second year. In clay, fine sand and Carex peat, each crop was analyzed for $\mathrm{Zn}$. In Sphagnum peat, a few crops were pooled in the second year in order to reduce the number of analyses. At the end of the experiment, soil samples of each pot were analyzed for $\mathrm{Zn}_{\mathrm{Ac}}$ and $\mathrm{pH}$.

During the experiment, atmospheric deposition of $\mathrm{Zn}$ was monitored in the greenhouse. Six Petri dishes (area $60.8 \mathrm{~cm}^{2}$ ) were kept open in the greenhouse compartment where the pots were grown and six capped Petri dishes served as controls. After two months the Petri dishes were washed with $25 \mathrm{ml}$ of $1 \mathrm{M} \mathrm{HCl}$ and the extracts were analyzed for $\mathrm{Zn}$.

\subsubsection{Dry matter yields and plant $\mathrm{Zn}$ concentrations}

The total dry matter yields, not presented in detail, were $33.6,27.3$ and $28.3 \mathrm{~g}$ per pot in clay, fine sand and Carex peat, respectively, and they were not affected either by $\mathrm{Zn}$ application or by liming. In Sphagnum peat the grass tended to be paler green at the highest $\mathrm{Zn}$ rate $\left(100 \mathrm{mg} \mathrm{dm}^{-3}\right)$ throughout the experiment as compared to the other pots. There seemed to be a slight yield decrease towards the higher rates of $\mathrm{Zn}$ application (Table 43), which may be an indication of excess of $\mathrm{Zn}$. The dry matter production in Sphagnum peat at the higher liming rate was $5 \%$ higher than that at the lower rate

Table 43. Sum of five yields ( $\mathrm{g}$ per pot) grown in Sphagnum peat. ${ }^{\prime}$

\begin{tabular}{lcc}
\hline Zn application, $\mathrm{mg} \mathrm{dm}^{-3}$ & Liming rate I & Liming rate II \\
\hline 0 & $124.2^{\mathrm{a}}$ & $129.9^{\mathrm{a}}$ \\
5 & $119.8^{\mathrm{ab}}$ & $129.8^{\mathrm{a}}$ \\
10 & $125.2^{\mathrm{a}}$ & $129.9^{\mathrm{a}}$ \\
20 & $122.3^{\mathrm{ab}}$ & $127.5^{\mathrm{ab}}$ \\
50 & $119.6^{\mathrm{ab}}$ & $125.4^{\mathrm{ab}}$ \\
100 & $115.1^{\mathrm{b}}$ & $121.6^{\mathrm{b}}$ \\
$\mathrm{HSD}_{0.05}$ & $8.1^{\mathrm{b}}$ & 6.3 \\
\hline
\end{tabular}

1 Results of the two liming rates were tested separately. 
$\left(\mathrm{F}=47.083^{* * *}\right)$. The additional three crops grown in pots of 0 or $10 \mathrm{mg} \mathrm{Zn} \mathrm{dm}^{-3}$ increased the total dry matter yield to an average of $181 \mathrm{~g}$ per pot, with no differences between the treatments.

Application of $\mathrm{Zn}$ elevated the $\mathrm{Zn}$ concentration of grass substantially in all soils (Figure 8). In Sphagnum peat $\mathrm{Zn}$ addition increased the $\mathrm{Zn}$ concentration of grass most effectively. For example, $\mathrm{Zn}$ application of $10 \mathrm{mg} \mathrm{dm}^{-3}$ elevated the $\mathrm{Zn}$ concentration of grass by $65 \mathrm{mg} \mathrm{kg}^{-1}$ in the first crop in Sphagnum peat and by $107-145 \mathrm{mg} \mathrm{kg}^{-1}$ in the next ones, while in clay, fine sand and Carex peat the corresponding increase was only $10-31 \mathrm{mg}$ $\mathrm{kg}^{-1}$. The highest $\mathrm{Zn}$ concentrations of plants at the $\mathrm{Zn}$ application rate of $40 \mathrm{mg} \mathrm{dm}^{-3}$ remained below $100 \mathrm{mg} \mathrm{kg}^{-1}$ in clay and Carex peat. This level was slightly exceeded in the first crop in the limed fine sand, while $200 \mathrm{mg} \mathrm{kg}^{-1}$ was reached at the highest application rate in the unlimed fine sand. The regression curves of Sphagnum peat showed that the grass grown in that soil would have contained as much as $250-400 \mathrm{mg} \mathrm{Zn} \mathrm{kg}^{-1}$ at the application rate of $40 \mathrm{mg} \mathrm{Zn} \mathrm{dm}^{-3}$. The maximum application rate in Sphagnum peat $\left(100 \mathrm{mg} \mathrm{dm}^{-3}\right)$ gave rise to $\mathrm{Zn}$ concentrations exceeding $500 \mathrm{mg} \mathrm{kg}^{-1}$ at both liming rates.

The efficiency of applied $\mathrm{Zn}$ was assessed by studying the slopes of the regression lines calculated between the quantity of added $\mathrm{Zn}\left(\mathrm{mg} \mathrm{dm}^{-3}\right)$ and $\mathrm{Zn}$ concentration $\left(\mathrm{mg} \mathrm{kg}^{-1}\right.$ ) of grass (Table 44). Despite the slight curvilinearity of the response in clay soil and in Carex and Sphagnum peat, the linear regression equations were used. The equa- tions of Sphagnum peat were calculated using the results of the first and second crop and $\mathrm{Zn}$ additions up to $50 \mathrm{mg} \mathrm{dm}^{-3}$. All possible pairs of the regression coefficients were tested separately for each crop and liming rate (RANTA et al. 1991, p. 395). According to the regression coefficients, the effect of $\mathrm{Zn}$ application was the greatest in Sphagnum peat, followed by fine sand. The effect was smaller in clay and still smaller in Carex peat, although the difference between these two soils was not significant in the second crop in the limed soils. Liming lowered the efficiency of $\mathrm{Zn}$ application in clay ( $\mathrm{P}$ $=0.001)$ and especially in fine sand $(\mathrm{P}=0.001)$ but had a relatively smaller but significant effect $(\mathrm{P}=$ $0.05)$ in the two peat soils. The efficiency of added $\mathrm{Zn}$ decreased in clay and unlimed fine sand from the first crop to the second one, while in Sphagnum peat the efficiency increased. In Carex peat and limed fine sand the efficiency was unchanged from the first to the second crop.

Despite substantial increases in $\mathrm{Zn}$ concentration of grass, the utilization (\%) of added $\mathrm{Zn}$ in clay, fine sand and Carex peat remained low, ranging in the unlimed pots from 0.4 to $1.7 \%$ and in the limed pots from 0.0 to $1.4 \%$. In the first two crops grown in Sphagnum peat, the utilization of added $\mathrm{Zn}$ ranged from $3.1 \%$ to $6.1 \%$. In the total of five crops, the utilization ranged from 22 to $8 \%$, decreasing steadily from the lowest to the highest rate of added $\mathrm{Zn}$. In the pots grown for three more crops, the utilization of added $\mathrm{Zn}$ rose to $34.5 \%$ at the rate of $10 \mathrm{mg}$ $\mathrm{Zn} \mathrm{dm}{ }^{-3}$ without any indication of decreased $\mathrm{Zn}$ availability over time.

Table 44. Regression coefficients (b) and coefficients of determination $\left(\mathrm{R}^{2}\right)$ of the linear regression equations between $\mathrm{Zn}$ addition $\left(\mathrm{mg} \mathrm{dm}^{-3}\right)$ and plant $\mathrm{Zn}$ concentration $\left(\mathrm{mg} \mathrm{kg}^{-1}\right)$.

\begin{tabular}{|c|c|c|c|c|c|c|c|c|}
\hline \multirow[t]{3}{*}{ Soil } & \multicolumn{4}{|c|}{ Crop I } & \multicolumn{4}{|c|}{ Crop II } \\
\hline & \multicolumn{2}{|c|}{ Unlimed' } & \multicolumn{2}{|c|}{ Limed $^{3}$} & \multicolumn{2}{|c|}{ Unlimed ${ }^{1}$} & \multicolumn{2}{|c|}{ Limed $^{3}$} \\
\hline & b & $\mathbf{R}^{2}$ & b & $\mathbf{R}^{2}$ & b & $\mathrm{R}^{2}$ & b & $\mathbf{R}^{2}$ \\
\hline Clay & 1.37 & 0.98 & 1.05 & 0.98 & 1.15 & 0.97 & 0.77 & 0.95 \\
\hline Fine sand & 3.64 & 0.99 & 1.64 & 0.84 & 2.74 & 0.97 & 1.36 & 0.83 \\
\hline Carex peat & 1.02 & 0.98 & 0.84 & 0.94 & 1.01 & 0.98 & 0.74 & 0.69 \\
\hline Sphagnum peat & 5.09 & 0.97 & 4.35 & 0.97 & 7.53 & 0.99 & 6.80 & 0.98 \\
\hline
\end{tabular}

' Liming rate I in Sphagnum peat.

${ }^{3}$ Liming rate II in Sphagnum peat. 

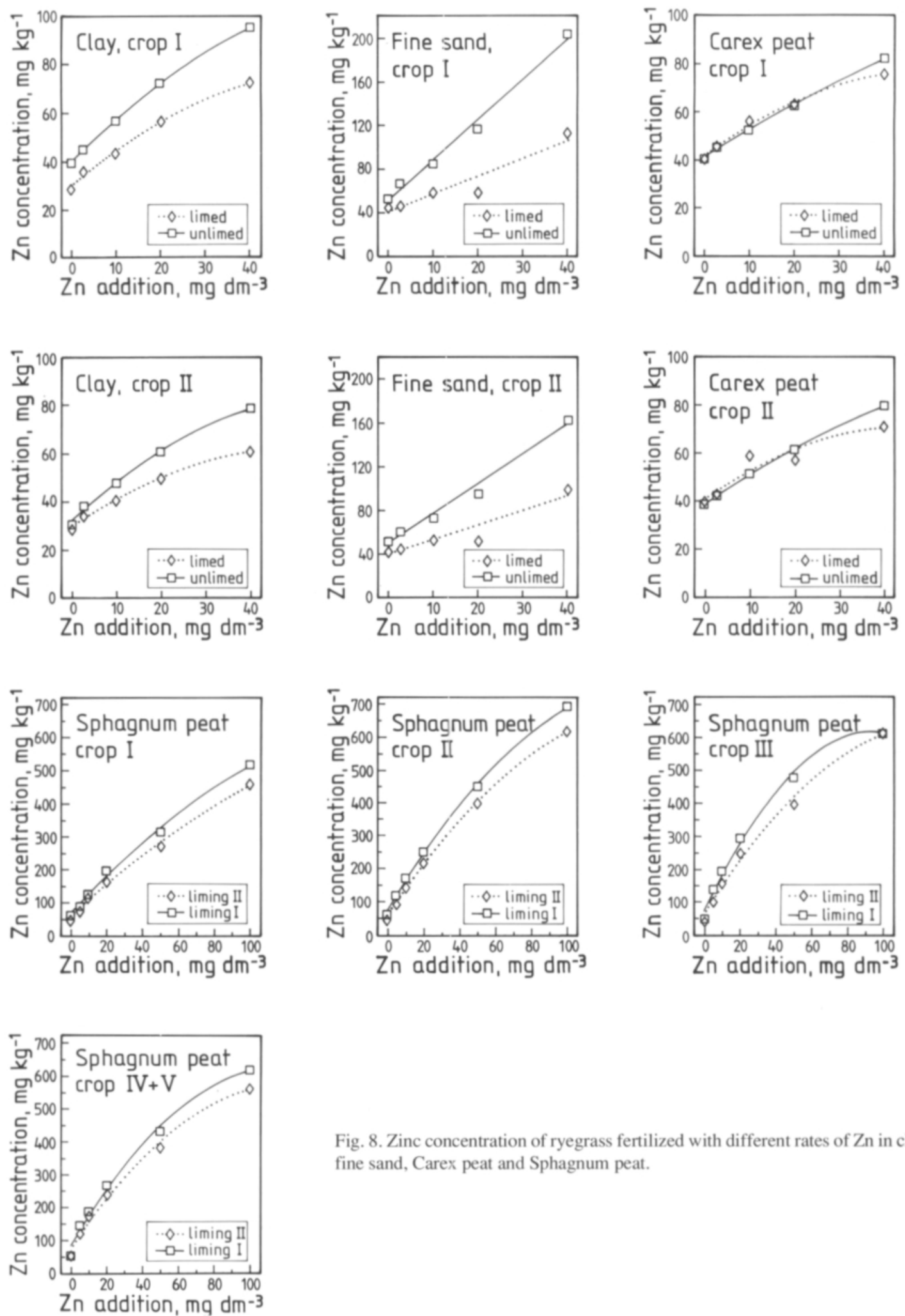

Fig. 8. Zinc concentration of ryegrass fertilized with different rates of $\mathrm{Zn}$ in clay, fine sand, Carex peat and Sphagnum peat. 


\subsubsection{Atmospheric deposition of $\mathrm{Zn}$ in the greenhouse}

In the greenhouse, the quantities of $\mathrm{Zn}\left(\mathrm{mg} \mathrm{m}^{-2}\right)$ analyzed in the Petri dishes during two months were as follows:

$\begin{array}{lll} & \text { Mean } & \text { Range } \\ \text { Open dishes } & 1.34 & 0.54-2.11 \\ \text { Capped dishes } & 0.06 & 0.05-0.08\end{array}$

Assuming that the same deposition had fallen over the grassed pots (area $363 \mathrm{~cm}^{2}$ ), a fallout of 49 $\mu \mathrm{g}$ per pot can be expected over 2 months. The average total uptake of $\mathrm{Zn}$ from the control pots of clay, fine sand and Carex peat ranged from $900 \mu \mathrm{g}$ per pot in clay to $1500 \mu \mathrm{g}$ per pot in fine sand. The deposited $\mathrm{Zn}$ thus ranged from 3 to $6 \%$ of the measured $\mathrm{Zn}$ uptake in the control pots. The deposition corresponded to $78 \mathrm{~g} \mathrm{ha}^{-1}$ over 12 months.

\subsubsection{Soil analyses at the end of the experiment}

Zinc addition to soil substantially elevated the quantities of $\mathrm{Zn}_{\mathrm{Ac}}$ determined at the end of the experiment (Table 45). The samples taken from clay soils to which 0 or $10 \mathrm{mg} \mathrm{Zn} \mathrm{dm}^{-3}$ had been applied were lost before the analysis. In all clay samples available, the final $\mathrm{Zn}_{\mathrm{Ac}}$ was lower than the amount of applied $\mathrm{Zn}$ plus the initial $\mathrm{Zn}_{\mathrm{Ac}}$, the difference being much greater than the $\mathrm{Zn}$ uptake by the grass. Inversely, in the unlimed fine sand the ultimate $\mathrm{Zn}_{\mathrm{Ac}}$ did not differ from the sum of $\mathrm{Zn}$ application plus the initial $\mathrm{Zn}_{\text {Ac. }}$. This difference between clay and fine sand may suggest retention of $\mathrm{Zn}$ in the clay soil into forms not extractable by AAAc-EDTA, while the availability of added $\mathrm{Zn}$ was maintained in the sand. In the two peat soils, on the contrary, the quantities of $\mathrm{Zn}_{\mathrm{Ac}}$ determined at the end of the experiment exceeded the sum of applied $\mathrm{Zn}$ and original $\mathrm{Zn}_{\mathrm{Ac}}$. This anomaly may be attributed to increasing bulk density of the organogenic soil during the experiment, owing to compaction and oxidation of organic matter.

Determination of soil $\mathrm{pH}$ at the end of the experiment showed that there was a significant (t-value
Table 45. Soil pH and $\mathrm{Zn}_{\mathrm{Ac}}\left(\mathrm{mg} \mathrm{dm}^{-3}\right)$ at the end of the pot experiment. ${ }^{1}$

\begin{tabular}{|c|c|c|c|c|}
\hline \multirow{2}{*}{$\begin{array}{l}\mathrm{Zn} \text { applica- } \\
\text { tion, } \mathrm{mg} \mathrm{dm}^{-3}\end{array}$} & \multicolumn{2}{|c|}{$\mathrm{Zn}_{\mathrm{Ac}}, \mathrm{mg} \mathrm{dm}^{-3}$} & \multicolumn{2}{|c|}{$\mathrm{pH}$} \\
\hline & Unlimed $^{2}$ & Limed $^{3}$ & Unlimed $^{2}$ & Limed $^{3}$ \\
\hline & & $-C^{-}$ & & \\
\hline 0 & - & - & - & - \\
\hline 2.7 & $2.0^{\mathrm{d}}$ & $1.6^{\mathrm{d}}$ & 5.5 & 6.0 \\
\hline 10 & - & - & - & - \\
\hline 20 & $11.2^{\mathrm{c}}$ & $9.0^{\mathrm{c}}$ & 5.6 & 6.0 \\
\hline 40 & $25.4^{\mathrm{a}}$ & $17.0^{\mathrm{b}}$ & 5.6 & 6.0 \\
\hline $\mathrm{HSD}_{0.05^{4}}$ & 6.5 & & & \\
\hline 0 & $3.3^{\mathrm{fg}}$ & $2.9^{\mathrm{g}}$ & 5.1 & 5.5 \\
\hline 2.7 & $6.4^{f}$ & $4.1^{f g}$ & 5.1 & 5.9 \\
\hline 10 & $10.6^{\mathrm{de}}$ & $7.8^{\mathrm{ef}}$ & 5.0 & 5.6 \\
\hline 20 & $21.0^{\circ}$ & $12.9^{\mathrm{d}}$ & 5.1 & 6.3 \\
\hline 40 & $40.5^{\mathrm{a}}$ & $32.1^{b}$ & 4.8 & 6.1 \\
\hline $\mathrm{HSD}_{0.05^{4}}$ & 3.2 & & & \\
\hline 0 & $3.5^{\mathrm{d}}$ & $2.6^{\mathrm{d}}$ & 5.2 & 5.9 \\
\hline 2.7 & $5.9^{\mathrm{cd}}$ & $6.4^{\text {cd }}$ & 5.5 & 6.4 \\
\hline 10 & $11.5^{\mathrm{c}}$ & $10.7^{c}$ & 5.4 & 5.7 \\
\hline 20 & $24.9^{b}$ & $25.1^{\mathrm{b}}$ & 5.6 & 6.3 \\
\hline 40 & $53.1^{\mathrm{a}}$ & $49.8^{\mathrm{a}}$ & 5.6 & 6.2 \\
\hline \multirow[t]{2}{*}{$\mathrm{HSD}_{0.05^{4}}$} & 7.0 & & & \\
\hline & & Sphagn & m peat & . \\
\hline 0 & $1.5^{\mathrm{d}}$ & $4.0^{\mathrm{d}}$ & 4.6 & 5.2 \\
\hline 5 & $10.5^{\mathrm{cd}}$ & $6.9^{\mathrm{d}}$ & 4.5 & 5.3 \\
\hline 10 & $12.5^{\mathrm{cd}}$ & $11.7^{\mathrm{cd}}$ & 4.7 & 5.2 \\
\hline 20 & $22.5^{\mathrm{c}}$ & $25.5^{\mathrm{c}}$ & 4.7 & 5.3 \\
\hline 50 & $56.5^{\mathrm{b}}$ & $57.6^{\mathrm{b}}$ & 4.7 & 5.2 \\
\hline 100 & $123.0^{a}$ & $108.5^{\mathrm{a}}$ & 4.5 & 5.1 \\
\hline $\mathrm{HSD}_{0.05^{4}}$ & 15.5 & & & \\
\hline
\end{tabular}

1 Results of each soil were tested separately.

${ }^{2}$ Liming rate $I$ in Sphagnum peat.

${ }^{3}$ Liming rate II in Sphagnum peat.

${ }^{4} \mathrm{HSD}_{0.05}$ for $\mathrm{Zn}_{\mathrm{Ac}}$

$4.56^{* *}-15.85^{* * *}$ ) difference in soil $\mathrm{pH}$ between the two liming levels in Sphagnum peat and between the limed and unlimed pots of the other three soils. The difference was greatest $(0.8 \mathrm{pH}$ units $)$ in fine sand where liming lowered most effectively plant $\mathrm{Zn}$ concentration. In the other three soils the difference was 0.4 - $0.6 \mathrm{pH}$ units. Liming also caused a decrease in $\mathrm{Zn}_{\mathrm{Ac}}$ determined at the end of the experiment in clay and fine sand $\left(\mathrm{F}=14.019^{* *}\right.$ and $\mathrm{F}$ $=41.763^{* * *}$, respectively), while in Carex and Sphagnum peat the difference between the two lim- 
ing rates was not statistically significant $(\mathrm{P}=0.308$ and $\mathrm{P}=0.279$, respectively).

\subsection{Discussion}

The adequacy of soil $\mathrm{Zn}$ supply to plant can be assessed by measuring the dependence of plant growth on the Zn status of soil (LINS and COX 1988, ARMOUR et al. 1990, BRENNAN and GARTRELL 1990). The critical level of $\mathrm{Zn}$ in soil has been determined as the quantity of extractable $\mathrm{Zn}$ above which no yield increase is obtained by $\mathrm{Zn}$ application. The present pot experiments did not allow to determine the critical level of $\mathrm{Zn}_{\mathrm{Ac}}$, because the dry matter production was not dependent on the status of soil $\mathrm{Zn}$, and the yields were not increased by $\mathrm{Zn}$ application even though a few soils in the material were rated poor in $\mathrm{Zn}_{\mathrm{Ac}}\left(<1.0 \mathrm{mg} \mathrm{dm}^{-3}\right)$. The adequate size of the native $\mathrm{Zn}$ reserves was also displayed by the fact that in spite of the high growth intensity in the pot experiment, the average $\mathrm{Zn}$ concentration of the ryegrass grown in 107 soils was of the same magnitude as the average of fieldgrown timothy in Finland $\left(30.8 \pm 13.2 \mathrm{mg} \mathrm{kg}^{-1}\right.$ by LAKANEN 1969, $32.0 \pm 8.5 \mathrm{mg} \mathrm{kg}^{-1}$ by KÄHÄRI and NISSINEN 1978).

Zinc needs to enter the solution phase as $\mathrm{Zn}^{2+}$ cation in order to be taken up by the plant. It is the fraction extracted with $\mathrm{MgCl}_{2}$ that contains watersoluble and exchangeable $\mathrm{Zn}$ readily available to plants. However, the four crops of grass were able to take up more $\mathrm{Zn}$ than was originally extracted with $\mathrm{MgCl}_{2}$ from several of the 107 surface soils especially in the higher $\mathrm{pH}$ range. It is feasible that during the experiment there was a flux of $\mathrm{Zn}$ from the more strongly bound fractions into the soluble one. This hypothesis is supported by the results of BAKHSH et al. (1990) and TORRES-MARTIN and GALLARDO-LARA (1991) who measured an increase in $\mathrm{Zn}$ extracted with $0.01 \mathrm{M} \mathrm{CaCl}_{2}$ or $1 \mathrm{M}$ $\mathrm{MgCl}_{2}$ during the plant growth with a consequent decrease in the fraction bound by Fe oxide. As compared to the bulk of the soil, increased concentration of $\mathrm{Zn}$ in the rhizosphere of maize, wheat and barley has also been measured by LINEHAN et al. (1985) and MERCKX et al. (1986). The increase was attributed to the influence of the lower $\mathrm{pH}$ and the abundance of chelating root exudates in the rhizosphere, both mobilizing $\mathrm{Zn}$ from reserves less soluble than $\mathrm{Zn}_{\text {ex }}$.

Some authors have reported a very close correlation between soil $\mathrm{Zn}_{\mathrm{ex}}$ and $\mathrm{Zn}$ concentration of plants grown in pot experiments (DAVIES 1985, NIELSEN et al. 1987) and in the field (MERKEL and KÖSTER 1977, SAUERBECK and STYPEREK 1985). Neutral salt solutions $\left(\mathrm{NaNO}_{3}, \mathrm{CaCl}_{2}\right)$ have been proposed for extractants of $\mathrm{Zn}$ especially in polluted soils rich in Zn (HÄNI and GUPTA 1985, SAUERBECK and STYPEREK 1985, HOUBA et al. 1990). These solutions may not, however, be the most suitable in unpolluted soils where plants also utilize $\mathrm{Zn}$ reserves which are less soluble than $\mathrm{Zn}_{\text {ex }}$. In the present study, $\mathrm{Zn}$ extracted by $\mathrm{MgCl}_{2}$ did correlate significantly with $\mathrm{Zn}$ uptake by ryegrass, but in mineral soils AAAc-EDTA which dissolved also complexed $\mathrm{Zn}$ yielded results which correlated even more closely with $\mathrm{Zn}$ uptake by the grass. It was also observed by NIELSEN et al. (1987) that in non-contaminated soils poor in $\mathrm{Zn}$, only ZnDTPA, but not $\mathrm{Zn}_{\mathrm{ex}}$, correlated with $\mathrm{Zn}$ uptake by plants.

Soil $\mathrm{Zn}_{\mathrm{Ac}}$ and $\mathrm{Zn}_{\mathrm{py}}$, determined at the beginning of the pot experiment, were relatively the most important soil characteristics to explain the variation of the uptake of soil $\mathrm{Zn}$ throughout the four crops. AAAc-EDTA and pyrophosphate thus extracted $\mathrm{Zn}$ from the same fractions which serve as the source of $\mathrm{Zn}$ for plants. Contrary to $\mathrm{Zn}_{\mathrm{ex}}$ underestimating $\mathrm{Zn}$ supply in soils of high $\mathrm{pH}, \mathrm{Zn}_{\mathrm{Ac}}$ and $\mathrm{Zn}_{\text {py }}$ overestimated the $\mathrm{Zn}$ supplying power in the same mineral soils. It is possible that $\mathrm{Zn}$ unavailable to plants may be extracted by AAAc-EDTA buffered to $\mathrm{pH} 4.65$ especially from soils which are less acid than the extractant. This assumption is supported by the results of JAHIRUDDIN et al. (1986) obtained in acid soils of Scotland. There, $1 \mathrm{M}$ ammonium acetate, adjusted to different $\mathrm{pH}$ values, dissolved more $\mathrm{Zn}$ at $\mathrm{pH} 4.8$ than did the solution adjusted to soil $\mathrm{pH}$ above 4.8 , and the additional quantity of $\mathrm{Zn}$ dissolved at $\mathrm{pH} 4.8$ was the greater the higher was the soil $\mathrm{pH}$. The present study showed that also pyrophosphate at $\mathrm{pH} 10$ was less sensitive than ryegrass to decreased $\mathrm{Zn}$ solubility induced by increasing $\mathrm{pH}$. Corresponding observa- 
tions have been reported earlier (HAQ and MILLER 1972, HORNBURG and BRÜMMER 1991) when extracting soil $\mathrm{Zn}$ with various EDTA and DTPA containing solutions.

The above findings support a $\mathrm{pH}$-dependent interpretation of $\mathrm{Zn}_{\mathrm{Ac}}$, in principle suggested by $\mathrm{S}_{\mathrm{IL}}$ LANPÄÄ (1982). This means that at a low pH a given result of $\mathrm{Zn}_{\mathrm{Ac}}$ corresponds to a larger $\mathrm{Zn}$ supply to plants than the same result in a soil of higher $\mathrm{pH}$, and the more acid soil gets a higher rating in soil testing. A highly $\mathrm{pH}$-dependent interpretation of ZnDTPA in soils of Australia has also been proposed (BRENNAN and GARTRELL 1990). However, when extracting soil $\mathrm{Zn}$ with chelating agents (EDTA and DTPA) the need of a pH correction is not as crucial as it is when mineral acids are used as extractants for $\mathrm{Zn}$. For example, in the study of JUNUS and COX (1987) the results of Mehlich 3 extraction explained the variation of $\mathrm{Zn}$ uptake by soybean and corn from soils of North Carolina, USA, only when soil $\mathrm{pH}$ was taken into account.

In extremely intensive pot experiments also $\mathrm{Zn}_{\text {ox }}$ was a source of plant-available $\mathrm{Zn}$ in mineral soils even though $\mathrm{Zn}_{\mathrm{ox}}$ has been considered virtually unavailable to plants (IYENGAR et al. 1981, PAYNE et al. 1988). The increase of plant $\mathrm{Zn}$ concentration towards the end of the experiment (Section 4.1) in the mineral soils may reflect the increased solubility of $\mathrm{Zn}_{\text {ox }}$ over time. The decrease of soil $\mathrm{pH}$ during the experiment can have caused partial dissolution of the $\mathrm{Zn}_{\text {ox }}$ fraction, which has been reported to respond to soil acidification (HAYNES and SWIFT 1985). In turn, in organogenic soils the decrease of plant $\mathrm{Zn}$ concentration during the trial may reflect the scarce $\mathrm{Zn}_{\text {ox }}$ reserves in these soils.

In several previous studies (WEAR 1956, LEYDEN and TOTH 1960, AASEN 1981, SIMS 1986, JUNUS and COX 1987, BoswELL et al. 1989) liming of an acid soil has been shown to reduce the fertilizer efficiency of added $\mathrm{Zn}$. The same finding as well as an observation that $\mathrm{Zn}$ Ac decreased upon liming were made in this study in a pot experiment with clay and fine sand (Section 4.3). However, a more noteworthy observation of $\mathrm{pH}$ and fertilizer efficiency of added $\mathrm{Zn}$ was made in the larger material of mineral surface soils (Section 4.2) where soil $\mathrm{pH}$ proved a relatively more important characteristic than native $\mathrm{Zn}_{\mathrm{Ac}}$ in determining the effect of added $\mathrm{Zn}$ on plant $\mathrm{Zn}$ concentration. According to several studies, the equilibrium $\mathrm{Zn}$ concentration in soil solution or in the liquid phase of a soil suspension decreases and $\mathrm{Zn}$ adsorption increases with increasing $\mathrm{pH}$ of an acid soil (McBRIDE and BLASIAK 1979, BRÜMMER et al. 1983, JEFFERY and UREN 1983, TILLER et al. 1984, PULFORD 1986, MSAKY and CALVET 1990). A decrease of $\mathrm{Zn}$ concentration in the soluble phase seems to indicate an increased specific adsorption (TILler et al. 1984, SHUMAN 1986, SiMS 1986) which evidently results in a decreased tendency for desorption and lower plant-availability of $\mathrm{Zn}$ (EL KHERBAWY and SANDERS 1984). Thus, soil pH by and large determines which part of fertilizer $\mathrm{Zn}$ remains plant-available and which is converted into unavailable forms.

Unlike mineral soils, $\mathrm{Zn}_{\text {py }}$ or $\mathrm{Zn}_{\text {Ac }}$ explained alone the variation of the uptake of $\mathrm{Zn}$ from organogenic soils by ryegrass without a significant contribution of other soil properties. The insignificance of other variables may partly be caused by the small number of organogenic soils and a narrower $\mathrm{pH}$ range, which may not have allowed the influence of soil $\mathrm{pH}$ to be observed as clearly as in mineral soils. It is also possible that the influence of soil $\mathrm{pH}$ on $\mathrm{Zn}$ solubility in organogenic soils is different from that in mineral soils. This conclusion can be drawn on the basis of the results of a pot experiment (Section 4.3) where liming highly affected the response of ryegrass to applied $\mathrm{Zn}$ in the two mineral soils but had only a minor influence in the two peat soils despite a significant increase in soil $\mathrm{pH}$ also in these soils. A similar observation was made by WolTZ et al. (1953) in New Jersey, USA, where an elevation of the $\mathrm{pH}$ from 6.0 to 7.0 decreased the $\mathrm{Zn}$ uptake by red clover in mineral soils but did not do so in a peat soil. Also JEFFERY and UREN (1983) observed that mixing peat in an acid mineral soil reduced the decrease of $\mathrm{Zn}$ concentration in soil solution when the $\mathrm{pH}$ was elevated. McBRIDE and BLASIAK (1979) attributed the pH-dependent increase of $\mathrm{Zn}$ adsorption in acid mineral soils to the reactions of $\mathrm{Zn}$ with $\mathrm{Fe}, \mathrm{Al}$ and $\mathrm{Mn}$ oxides and considered the reactions with organic matter to be of minor importance. If this is true and the fraction 
of $\mathrm{Zn}$ bound by organic matter plays a more important role as a source of soluble $\mathrm{Zn}$ in organogenic soils, soil $\mathrm{pH}$ may in organogenic soils indeed have a less marked effect on $\mathrm{Zn}$ solubility than in mineral soils.

In organogenic soils, the AAAc-EDTA method was able to recognize soils which, according to the pot experiment, had the smallest reserves of plantavailable $\mathrm{Zn}$. In those peat soils native $\mathrm{Zn}$ reserves were most strongly utilized, and also added $\mathrm{Zn}$ remained available to plants, effectively elevating plant $\mathrm{Zn}$ concentration. However, the soil characteristics controlling the relative utilization of $\mathrm{Zn}$ in organogenic soils remained ambiguous. Moreover, in a very acid peat soil $(100, \mathrm{pH} 3.8) \mathrm{Zn}$ concentra- tion and uptake of ryegrass were low in spite of abundant $\mathrm{Zn}_{\mathrm{Ac}}$ reserves in the soil. In this soil and in another highly acid peat $(105, \mathrm{pH} 4.1)$, also the response to applied $\mathrm{Zn}$ was small even though at this $\mathrm{pH}$ the solubility of added $\mathrm{Zn}$ was inevitably high. An increase in $\mathrm{Al}^{3+}$ concentration in a nutrient solution culture has been reported to reduce the concentration of $\mathrm{Zn}$ in ryegrass (RENGEL and ROBINSON 1989). It has also been observed that timothy grown in acid sulphate soils rich in exchangeable $\mathrm{Al}$ had a low $\mathrm{Zn}$ concentration in spite of a rather high $\mathrm{Zn}_{\mathrm{Ac}}$ in the respective soils (PALKO 1986). The adverse effects of $\mathrm{Al}$ may thus have caused the low $\mathrm{Zn}$ uptake of soil and fertilizer $\mathrm{Zn}$ in the two extremely acid peat soils.

\section{FERTILIZERS AS ZINC SOURCES IN POT AND FIELD EXPERIMENTS}

Qualitative relationship between soil and plant $\mathrm{Zn}$ can be studied in laboratory and pot experiments, but these studies do not tell the quantitative effect of applied $\mathrm{Zn}$ on the crop grown in the field where $\mathrm{Zn}$ fertilization is actually practiced. Moreover, in the pot experiments reported earlier in this study only $\mathrm{ZnSO}_{4}$ was used as the source of $\mathrm{Zn}$. In practice, the quantities of solid $\mathrm{ZnSO}_{4}$ corresponding to $\mathrm{Zn}$ fertilizer recommendations are too small to allow uniform spreading, and therefore fertilizers of lower $\mathrm{Zn}$ concentration have been developed in which $\mathrm{ZnSO}_{4}$ is incorporated in different carriers, facilitating uniform application with common machinery. In addition to the application to the soil, $\mathrm{Zn}$ fertilization of the crop can be carried out by foliar sprays. In order to study the effect of different sources, rates and application methods of $\mathrm{Zn}$ on the yield and $\mathrm{Zn}$ concentration of the crop, field experiments were carried out with timothy and barley at the Kotkaniemi Experimental Farm of Kemira Oy and in the neighboring fields in Vihti in southern Finland $\left(60^{\circ} 22^{\prime} \mathrm{N}, 24^{\circ} 22^{\prime}\right.$ E). To complement the field experiments, a pot trial was conducted on the effect of different fertilizers on the $\mathrm{Zn}$ concentration of ryegrass.

\subsection{Experimental}

\subsubsection{Fertilizers}

The fertilizers consisted of commercial fertilizers as well as products specifically manufactured for the experiments (Table 46). The commercial $\mathrm{Zn}$ fertilizer 'Sinkkilannos' consists of $\mathrm{ZnSO}_{4}$ mixed with gypsum, and the dry mixture is granulated. In addition to straight $\mathrm{Zn}$ fertilizers, there were four NPK fertilizers to which $\mathrm{Zn}$ was added as $\mathrm{ZnSO}_{4}$. Addition of $\mathrm{Zn}$ to the commercial NPK fertilizer 'Vähäfosforinen Y-lannos' (18-3-12, N-P-K) is carried out by mixing $\mathrm{ZnSO}_{4}$ in the fertilizer slurry resulting in the distribution of $\mathrm{Zn}$ in the entire granule. The coated NPK fertilizers containing $\mathrm{Zn}$ were made by coating grains of a commercial NPK fertilizers (17-6-12 or 25-4-4, \% N-P-K) with $\mathrm{ZnSO}_{4}$ in the pilot hall of Kemira Oy Espoo Research Centre. Based on the results of Ellis et al. (1965), it was hypothesized that $\mathrm{Zn}$ might be more available when it is applied onto the granule as opposed to mixing in the slurry before granulation. After the field experiments were set up, it turned out that the fertilizer 18-3-12 contained $0.26 \%$ of $\mathrm{Zn}$ instead of 
Table 46. Concentration of $\mathrm{N}, \mathrm{P}, \mathrm{K}$ and $\mathrm{Zn}$ as well as $\mathrm{pH}$ of the fertilizers used in the field experiments and in the respective pot experiment.

\begin{tabular}{|c|c|c|c|c|c|}
\hline Fertilizer & $\mathrm{N}$ & $\mathrm{P}$ & K & $\mathrm{Zn}$ & $\mathrm{pH}$ \\
\hline $\mathrm{ZnSO}_{4}$ & - & - & - & 22.7 & - \\
\hline $\mathrm{Na}_{2} \mathrm{Zn}$-EDTA & - & - & - & 15.0 & - \\
\hline 'Sinkkilannos' & - & - & - & 2.6 & 4.3 \\
\hline NPK 18-3-121) & 18.0 & 3.1 & 12.2 & 0.26 & 5.3 \\
\hline Coated NPK I & 24.0 & 4.3 & 4.1 & 0.32 & 5.0 \\
\hline Coated NPK II & 16.9 & 6.0 & 12.0 & 0.21 & 5.4 \\
\hline Coated NPK III & 17.0 & 6.0 & 12.0 & 0.39 & 5.2 \\
\hline NPK 25-4-42) & 24.6 & 4.5 & 4.7 & 0.0024 & 5.4 \\
\hline NPK 20-4-83) & 20.1 & 4.2 & 7.8 & 0.0031 & 5.3 \\
\hline NPK 17-6-124) & 17.5 & 5.8 & 12.3 & 0.0062 & 5.3 \\
\hline NPK 14-9-105) & 14.2 & 8.4 & 9.9 & 0.0047 & 5.1 \\
\hline $\mathrm{KCl}$ & - & - & 50.5 & 0.0016 & - \\
\hline Triple superphosphate & - & 19.6 & - & 0.0144 & - \\
\hline
\end{tabular}

The Finnish trade names of the commercial NPK fertilizers: 1) 'Văhäfosforinen Y-lannos', 2) 'Typpirikas Y-lannos 1', 3) 'Typpirikas Y-lannos 2', 4) 'Typpirikas Y-lannos 3', 5) 'Fosforirikas Y-lannos'

$0.30 \%$ on which the experimental design was based. Therefore, $\mathrm{Zn}$ application to the plots receiving this fertilizer remained in reality slightly lower than intended.

\subsubsection{Experiments with ryegrass and timothy}

\section{a. Comparison of $\mathrm{Zn}$ fertilizers in a pot experiment}

Agronomic efficiency of a few $\mathrm{Zn}$ fertilizers used in the field experiments was tested in a pot experiment with ryegrass in clay, fine sand and Carex peat (Appendix 6). The clay and fine sand were taken from the sites were the field experiments with timothy were carried out. Zinc sulphate mixed in the soil served as reference fertilizer. The other treatments resembled the alternatives available in practical farming of forage crops. The commercial fertilizer 'Sinkkilannos' was mixed in the soil or was given as a topdressing, and the two $\mathrm{Zn}$-containing NPK fertilizers were surface-applied (Table 47). The two $\mathrm{Zn}$ rates were 2.7 (2.3 in NPK 18-312) and $10 \mathrm{mg} \mathrm{Zn} \mathrm{dm}^{-3}$ of soil.

There was $7 \mathrm{dm}^{3}$ of soil per pot and four replicates. At the beginning of the experiment, the same
Table 47. Applications of $\mathrm{Zn}$ in the pot experiment.

\begin{tabular}{lc}
\hline Treatment & $\mathrm{Zn}, \mathrm{mg} \mathrm{dm}^{-3}$ \\
\hline 1. Control, no Zn application & 0 \\
2. ZnSO & \\
3. 'Sinkkixed in the soil & 2.7 \\
4. 'Sinkkilannos' mixed in the soil & 2.7 \\
5. Zn in NPK 18-3-12 onto the soil & 2.7 \\
6. Zn in Coated NPK I onto the soil & 2.3 \\
7. ZnSO mixed in the soil & 2.7 \\
8. 'Sinkkilannos' mixed in the soil & 10 \\
9. 'Sinkkilannos' onto the soil & 10 \\
\hline
\end{tabular}

quantities of nutrients were applied as in the experiment reported in Section 4.3. The nutrient sources were compound NPK fertilizers and/or analytical grade chemicals. The pots to which $\mathrm{Zn}$-containing NPK fertilizers were added obtained the bulk of N, $\mathrm{P}$ and $\mathrm{K}$ in these compound fertilizers. For the second crop, $\mathrm{N}, \mathrm{P}$ and $\mathrm{K}$ were provided at the rate of 200,50 and $200 \mathrm{mg} \mathrm{dm}^{-3}$, respectively. Nutrient solutions made of $\mathrm{NH}_{4} \mathrm{NO}_{3}, \mathrm{KCl}$ and $\mathrm{KH}_{2} \mathrm{PO}_{4}$ were pipetted onto the surface of all pots in four portions at a few days intervals. The pots were grown in a greenhouse and watered daily with 
deionized water. The grass yields were dried at $60^{\circ} \mathrm{C}$ and analyzed for $\mathrm{Zn}$.

\section{b. Application of $\mathrm{Zn}$ fertilizers to timothy in the field}

The objective of the 2-year experiments, performed in clay and fine sand soils (Appendix 6), was to study whether $\mathrm{Zn}$ concentration of timothy was equally affected by a single application of straight $\mathrm{Zn}$ fertilizers and applications of $\mathrm{Zn}$ incorporated in NPK fertilizers spread for each yield. The swards were sown in 1990 and harvested in 1991 and 1992. During the experiment, all plots, except the control, received 3 or $6 \mathrm{~kg} \mathrm{Zn} \mathrm{ha}^{-1}\left(5.2 \mathrm{~kg} \mathrm{ha}^{-1}\right.$ in NPK 18-3-12) as a single dose or as multiple smaller applications. Foliar application of $\mathrm{Zn}$ to the growing sward was not made because $\mathrm{Zn}$ added that way can be adsorbed on the foliage without taking part in the reactions of the plant, which may cause irrelevant results of plant analysis. The different $\mathrm{Zn}$ applications, presented in detail in Appendix 7, were as follows:

1) Single application of a straight $\mathrm{Zn}$ fertilizer (ZnSO 4 or 'Sinkkilannos') at sowing (1990).

2) Single application of a straight $\mathrm{Zn}$ fertilizer ('Sinkkilannos') onto the sward in spring of the first year of cropping (1991).

3) Applications of $\mathrm{Zn}$-containing NPK fertilizers (NPK 18-3-12, Coated NPK II or Coated NPK III) onto the sward in spring and after cutting the first crop in both years of harvest (1991 and 1992).

When setting up the experiments, the fields were harrowed twice. Then, the granular $\mathrm{Zn}$ fertilizer 'Sinkkilannos' was broadcast and $\mathrm{ZnSO}_{4}$, dissolved in water, was sprayed on the appropriate plots. The NPK fertilization was applied with a fertilizer drill and timothy seeds were sown with a seed drill, simultaneously mixing 'Sinkkilannos' and $\mathrm{ZnSO}_{4}$ in the soil. The next spring, granular 'Sinkkilannos' was top-dressed on the assigned plots. In both experimental years, all plots received $\mathrm{N}, \mathrm{P}$ and $\mathrm{K}$ fertilization as a top dressing at the rates of 90,32 and $64 \mathrm{~kg} \mathrm{ha}^{-1}$, respectively. As mentioned earlier, two of the NPK fertilizers contained added $\mathrm{Zn}$. After the first cut in mid-June, when a few heads of timothy were emerging, NPK fertilization was applied again at the same rates and the swards were harvested for the second time later during the growing season. Owing to a drought in 1992 , the experiment in clay soil was irrigated on June 30 ( $28 \mathrm{~mm}$ of water) and the latter cut of both experiments took place as late as the end of September. In addition to the actual $\mathrm{Zn}$ fertilization, all plots received $19 \mathrm{~g} \mathrm{Zn} \mathrm{ha}^{-1}$ in the NPK fertilizer when the experiments were established. During the years of harvest, the plots received a maximum of $130 \mathrm{~g} \mathrm{Zn} \mathrm{ha}^{-1}$ as impurities of NPK fertilization. This quantity corresponds to $5 \%$ of the smaller application of $3 \mathrm{~kg} \mathrm{Zn} \mathrm{ha}^{-1}$ and can be considered negligible.

The stand was cut with a forage harvester. The yield of each plot was collected in a glass fibre box attached to the harvester. The plant samples, to be analyzed for $\mathrm{Zn}, \mathrm{N}$ and moisture, were taken just before the actual harvesting. The samples, composed of two subsamples of $0.25 \mathrm{~m}^{2}$ from each plot, were collected by hand using stainless steel scissors and weighed together with the harvested yield of the respective plot. Soil samples were taken from each plot and analyzed for $\mathrm{pH}$ and $\mathrm{Zn}_{\mathrm{Ac}}$ in the beginning and at the end of the experiment.

\subsubsection{Field experiments with barley}

\section{a. Comparison of $\mathrm{Zn}$ fertilizers}

The objective of the three 3-year field experiments carried out in 1990 through 1992 on clay, fine sand and mull soils (Appendix 6) was to establish whether $\mathrm{Zn}$ concentration of barley can be elevated with moderate $\mathrm{Zn}$ applications given in different fertilizers and whether a single application at the beginning of the experiments differs in efficiency from smaller annual applications. During the experiment, all plots, except the control, received $5.4 \mathrm{~kg} \mathrm{Zn} \mathrm{ha}^{-1}$ (4.8 $\mathrm{kg} \mathrm{ha}^{-1}$ in NPK 18-3-12) either as a single application at the beginning or as three annual applications of $1.8 \mathrm{~kg} \mathrm{Zn} \mathrm{ha}^{-1}(4 \times 1.6 \mathrm{~kg}$ $\mathrm{ha}^{-1}$ in NPK 18-3-12). The treatments, presented in detail in Appendix 8, were as follows: 
1) Single application of a straight $\mathrm{Zn}$ fertilizer ( $\mathrm{ZnSO}_{4}$ or 'Sinkkilannos') in the first spring of the trials.

2) Annual doses of $\mathrm{Zn}$ incorporated in granular NPK fertilizers (NPK 18-3-12 or Coated NPK I).

3) Annual doses of $\mathrm{Na}_{2} \mathrm{Zn}$-EDTA sprayed each spring onto the soil.

4) Annual doses of $\mathrm{Na}_{2} \mathrm{Zn}$-EDTA sprayed on the foliage.

Each spring the soil was harrowed twice. After harrowing, the granular $\mathrm{Zn}$ fertilizer ('Sinkkilannos') was broadcast (in 1990 only), and $\mathrm{ZnSO}_{4}$ (in 1990 only) and Na2Zn-EDTA (annually) were sprayed on the appropriate plots as water solutions. These fertilizers were mixed in the soil with a combined seed and fertilizer drill in connection with sowing and application of the NPK fertilizers. The granular NPK fertilizers, including added $\mathrm{Zn}$ in two fertilizers, were applied by the placement method. At the Feekes 5 growth stage (LARGE 1954), when the plants had usually reached the height of $10-15 \mathrm{~cm}$, water solution of $\mathrm{Na}_{2} \mathrm{Zn}$ EDTA was sprayed on the assigned plots. In 1992 , the experiment on clay soil was irrigated with 13 $\mathrm{mm}$ of water on July 1 . In addition to the actual $\mathrm{Zn}$ fertilization, the experiments on clay and fine sand received $37 \mathrm{~g} \mathrm{Zn} \mathrm{ha}^{-1}$ as impurities of other fertilizers during three years, except the plot fertilized with the NPK 18-3-12 and Coated NPK I. In mull soil, the corresponding quantity was $120 \mathrm{~g} \mathrm{Zn} \mathrm{ha}^{-1}$, owing to the larger $\mathrm{Zn}$ concentration of the NPK fertilizers used in that experiment.

The grain yield, harvested with an experimental harvester (Hege 125), was weighed and analyzed for moisture and $\mathrm{Zn}$. Also the straw was analyzed for $\mathrm{Zn}$ and moisture. The straw yield was weighed in the last two experimental years.

\section{b. Application of different $\mathrm{Zn}$ rates}

The objective of the two 2-year field experiments with barley was to investigate the effect of high $\mathrm{Zn}$ rates ( 15 and $30 \mathrm{~kg} \mathrm{ha}^{-1}$ ) on the $\mathrm{Zn}$ concentration of barley at different growth stages. The experiments, presented in detail in Appendix 9, were carried out in the same fine sand and clay soil (Appendix 6) in which the different $\mathrm{Zn}$ fertilizers were experimented. After harrowing in the first spring (1991) of the experiment, powdery $\mathrm{ZnSO}_{4}$ was applied by hand at the rate of 0,15 or $30 \mathrm{~kg} \mathrm{Zn} \mathrm{ha}^{-1}$ and mixed in the soil by harrowing for one more time. The NPK fertilizer was applied with the combined seed and fertilizer drill to supply $\mathrm{N}, \mathrm{P}$ and $\mathrm{K}$ at the rates of 110,22 and $44 \mathrm{~kg} \mathrm{ha}^{-1}$, respectively. In the second spring (1992), no $\mathrm{Zn}$ was added and the results of the second experimental year thus reflect the residual effect of the $\mathrm{Zn}$ fertilization. The quantity of $\mathrm{Zn}$ as impurity in the NPK fertilizer during the two years was $34 \mathrm{~g} \mathrm{ha}^{-1}$. In 1992, the experiment on clay soil was irrigated with $20 \mathrm{~mm}$ of water on July 1.

The plant samples were collected four times during the growing season from each plot by cutting the plants each time from two areas of $0.25 \mathrm{~m}^{2}$. The stand was sampled at the beginning of tillering (Feekes 2), at the end of tillering (Feekes 5), at the end of flowering (Feekes 10.5) and at maturity. The number of days from sowing to these growth stages was 38 - 39 days, 50 - 52 days, 69 - 70 days and 104 days, respectively, in 1991 and 26 - 28 days, 40 - 43 days, 61 days and 91 - 96 days, respectively, in 1992. The plant samples were dried and weighed. The grains were removed from the ears of mature plants by hand and the remnants of the ears were combined with the straw. The plant samples were analyzed for $\mathrm{Zn}$; the grains and straw were weighed and analyzed separately. At the end of the experiments, a composite soil sample of each plot was analyzed for $\mathrm{Zn}_{\mathrm{Ac}}$.

\subsubsection{Weather}

Precipitation and temperature were measured at the Kotkaniemi Experimental Farm. The three growing seasons in which the field experiments were conducted differed strongly in weather of the early summer. In 1990 and 1992, May and June were dry and warm (Table 48). In 1992, the drought continued until the end of July, resulting in a shortage of water especially in the experiments on the clay 
Table 48. Monthly mean temperatures and precipitations at the Kotkaniemi Experimental Farm during the months of growing seasons of the experimental years and means over a period of 18 years.

\begin{tabular}{|c|c|c|c|c|c|c|c|c|}
\hline \multirow[t]{2}{*}{ Month } & \multicolumn{4}{|c|}{ Temperature, ${ }^{\circ} \mathrm{C}$} & \multicolumn{4}{|c|}{ Precipitation, mm } \\
\hline & 1990 & 1991 & 1992 & $1974-91$ & 1990 & 1991 & 1992 & $1974-91$ \\
\hline May & 11.9 & 8.5 & 11.4 & 10.5 & 27 & 27 & 16 & 33 \\
\hline June & 16.0 & 13.8 & 16.1 & 14.8 & 14 & 58 & 16 & 44 \\
\hline July & 16.0 & 19.2 & 19.1 & 16.6 & 88 & 41 & 32 & 68 \\
\hline August & 16.5 & 16.7 & 16.6 & 15.0 & 49 & 98 & 90 & 76 \\
\hline September & 9.2 & 10.5 & 13.2 & 9.6 & 82 & 53 & 61 & 65 \\
\hline
\end{tabular}

Table 49. Concentration of $\mathrm{Zn}$ in ryegrass. I and II refer to the first and second crop, respectively. ${ }^{\prime}$

\begin{tabular}{|c|c|c|c|c|c|c|c|}
\hline \multirow[t]{3}{*}{ Treatment } & \multirow{3}{*}{$\begin{array}{l}\mathrm{Zn} \text { added } \\
\mathrm{mg} \mathrm{dm}^{-3}\end{array}$} & \multicolumn{6}{|c|}{$\mathrm{Zn}$ concentration $\left(\mathrm{mg} \mathrm{kg}^{-1}\right)$ of grass grown in } \\
\hline & & \multicolumn{2}{|c|}{ Fine sand } & \multicolumn{2}{|c|}{ Carex peat } & \multicolumn{2}{|c|}{ Clay } \\
\hline & & I & II & I & II & I & II \\
\hline Control & 0 & $52.9^{c}$ & $51.6^{\mathrm{d}}$ & $40.7^{\mathrm{d}}$ & $38.8^{\mathrm{e}}$ & $39.8^{\mathrm{cd}}$ & $31.0^{f}$ \\
\hline $\mathrm{ZnSO}_{4}$ & 2.7 & $66.6^{b}$ & $60.8^{\text {cd }}$ & $45.7^{\mathrm{bc}}$ & $42.5^{\mathrm{de}}$ & $45.4^{\mathrm{b}}$ & $38.4^{\mathrm{de}}$ \\
\hline 'Sinkkilannos' & 2.7 & $65.1^{\mathrm{b}}$ & $57.6^{\mathrm{d}}$ & $42.3^{\text {ed }}$ & $42.9^{\mathrm{de}}$ & $38.2^{\text {cd }}$ & $37.5^{\mathrm{e}}$ \\
\hline 'Sinkkilannos', s.a. ${ }^{2}$ & 2.7 & $56.0^{c}$ & $72.3^{\mathrm{bc}}$ & $41.2^{\mathrm{d}}$ & $44.2^{\mathrm{cd}}$ & $37.4^{d}$ & $45.8^{\mathrm{bc}}$ \\
\hline NPK 18-3-12, s.a. ${ }^{2}$ & 2.3 & $51.8^{\mathrm{c}}$ & $51.9^{\mathrm{d}}$ & $39.8^{d}$ & $42.0^{\mathrm{de}}$ & $38.6^{\mathrm{cd}}$ & $35.4^{\mathrm{ef}}$ \\
\hline Coated NPK I, s.a. ${ }^{2}$ & 2.7 & $54.4^{c}$ & $55.1^{\mathrm{d}}$ & $39.3^{\mathrm{d}}$ & $43.3^{\text {cde }}$ & $35.7^{\mathrm{d}}$ & $35.7^{\mathrm{e}}$ \\
\hline $\mathrm{ZnSO}_{4}$ & 10 & $84.7^{a}$ & $73.5^{\mathrm{b}}$ & $52.7^{\mathrm{a}}$ & $51.3^{\mathrm{b}}$ & $56.7^{\mathrm{a}}$ & $48.0^{b}$ \\
\hline 'Sinkkilannos' & 10 & $85.6^{\mathrm{a}}$ & $75.0^{\mathrm{b}}$ & $46.1^{\mathrm{bc}}$ & $47.8^{\mathrm{bc}}$ & $52.2^{\mathrm{a}}$ & $42.5^{\mathrm{ed}}$ \\
\hline 'Sinkkilannos', s.a. ${ }^{2}$ & 10 & $65.0^{\mathrm{b}}$ & $88.5^{\mathrm{a}}$ & $46.8^{b}$ & $58.8^{\mathrm{a}}$ & $43.2^{\mathrm{bc}}$ & $66.5^{\mathrm{a}}$ \\
\hline & $\mathrm{HSD}_{0.05}$ & 6.9 & 12.2 & 4.1 & 4.8 & 5.2 & 4.4 \\
\hline
\end{tabular}

${ }^{1}$ Results of each soil and crop were tested separately.

${ }^{2}$ s.a. $=$ surface-applied

soil. Inversely, in 1991 especially June was cooler and rainier than normal.

\subsection{Comparison of $\mathrm{Zn}$ fertilizers, $\mathrm{Zn}$ rates and application practices with grass crops}

\subsubsection{Effect of $\mathrm{Zn}$ fertilizers on ryegrass in a pot experiment}

Zinc application did not affect ryegrass yields in the pot experiment, and therefore only the mean yields obtained from each soil (g per pot) are presented:
Crop I Crop II

$\begin{array}{lrl}\text { Clay } & 13.7 & 20.1 \\ \text { Fine sand } & 9.9 & 18.1 \\ \text { Carex peat } & 12.2 & 16.6\end{array}$

At the lower rate $\left(2.7\right.$ or $\left.2.3 \mathrm{mg} \mathrm{Zn} \mathrm{dm}^{-3}\right), \mathrm{ZnSO}_{4}$ elevated $\mathrm{Zn}$ concentration of the first ryegrass crop in all soils (Table 49), but only in fine sand also the granular 'Sinkkilannos', mixed in the soil, had a significant effect. In the second crop, the effect of the fertilizers was different; granular 'Sinkkilannos' elevated plant $\mathrm{Zn}$ concentration relatively more efficiently than in the first crop, probably owing to a longer time available for the dissolution of the granules. In the second crop, the surface-applied 'Sinkkilannos' elevated plant Zn concentra- 
tion in all soils at least as effectively as $\mathrm{ZnSO}_{4}$ mixed in the soil. Actually, surface-applied 'Sinkkilannos' was the only fertilizer which elevated plant $\mathrm{Zn}$ concentration significantly at the lower application rate in the second crop in fine sand and Carex peat. The only significant effect of the two $\mathrm{Zn}$-containing NPK fertilizers on plant $\mathrm{Zn}$ concentration was observed in the second crop in clay with the coated NPK I.

At the higher application rate $\left(10 \mathrm{mg} \mathrm{dm}^{-3}\right)$ the increase of plant $\mathrm{Zn}$ concentration was substantially higher. In fine sand, 'Sinkkilannos' mixed in the soil was equal to $\mathrm{ZnSO}_{4}$ in efficiency in both crops, but in the first crop in Carex peat and in the second crop in clay, $\mathrm{ZnSO}_{4}$ was more efficient. Also at the higher $\mathrm{Zn}$ rate top-dressing of 'Sinkkilannos' was a less effective way of application than was mixing in the soil in the first crop in fine sand and clay soils. In the second crop the contrary was observed: topdressing of 'Sinkkilannos' was the most effective way of $\mathrm{Zn}$ application in all soils. The efficiency of the surface-application of 'Sinkkilannos' in the second yield was also emphasized when comparing the results obtained at the two $\mathrm{Zn}$ rates. Surface-applied 'Sinkkilannos' at the lower rate elevated $\mathrm{Zn}$ concentration of ryegrass as much as did the higher rate of 'Sinkkilannos' mixed in the soil. Despite substantial increases in $\mathrm{Zn}$ concentration of ryegrass, the utilization of added $\mathrm{Zn}$ remained at $1-2 \%$ in all soils.

\subsubsection{Effect of $\mathrm{Zn}$ fertilizers on timothy in the field}

All the four timothy yields (Table 50) obtained from the fine sand field during the two growing seasons were of normal size. Owing to poor growth, only two of the four blocks could be harvested in clay soil in the first experimental year and the first yields remained small also in the harvested blocks. Later, the yields obtained from the clay soil were of the same magnitude as those from the fine sand. The results concerning the clay soil represent the yield of those two blocks harvested in both years. Dry matter yields did not respond to $\mathrm{Zn}$ applications.
Table 50. Dry matter yields and raw protein $(6.25 \cdot \mathrm{N})$ contents of timothy. I and II refer to the first and second crop in the respective growing season.

\begin{tabular}{lcccc}
\hline Soil & \multicolumn{4}{c}{ Successive crop } \\
\cline { 2 - 5 } & I/1991 & II/1991 & I/1992 & II/1992 \\
\hline & \multicolumn{5}{c}{ Dry matter, kg ha ${ }^{-1}$} & \\
Clay & 1115 & 4054 & 3695 & 2350 \\
Fine sand & 2568 & 3935 & 4320 & 2100 \\
& & & Raw protein, \% & \\
Clay & 14.3 & 14.5 & 15.4 & 18.2 \\
Fine sand & 15.0 & 14.6 & 15.1 & 18.3 \\
\hline
\end{tabular}

The results of $\mathrm{Zn}$ concentration and uptake were tested with the analysis of variance using $\mathrm{Zn}$ fertilization and the crop (I/1991, II/1991, I/1992, II/1992) as the two criteria of classification. The results of the blocks served as replicates. The Fvalues in Table 51 suggest that in both experiments the systematic differences between the $\mathrm{Zn}$ concentrations of the four crops were at least as significant as those caused by the different fertilization treatments.

In clay soil, $\mathrm{Zn}$ concentration of timothy varied in a rather narrow range in the four crops of each treatment (Table 51). In fine sand, the ranges were slightly wider mainly because the $\mathrm{Zn}$ concentrations of crop II/1992 were substantially higher than those of the other crops. In neither experiment did the lower $\mathrm{Zn}$ rate $\left(3 \mathrm{~kg} \mathrm{ha}^{-1}\right)$ elevate the mean $\mathrm{Zn}$ concentration of timothy significantly. At the higher $\mathrm{Zn}$ rate $\left(6 \mathrm{~kg} \mathrm{ha}^{-1}\right)$ 'Sinkkilannos', applied by mixing in the soil or by top-dressing, elevated $\mathrm{Zn}$ concentration of timothy significantly in both soils. In addition, $\mathrm{Zn}$ concentration of the grass fertilized with $\mathrm{ZnSO}_{4}\left(6 \mathrm{~kg} \mathrm{Zn} \mathrm{ha}^{-1}\right)$ or with the coated NPK III ( $\left.6 \mathrm{~kg} \mathrm{Zn} \mathrm{ha}^{-1}\right)$ differed significantly from the control in clay soil. 'Sinkkilannos' mixed in the soil seemed to be slightly more effective at both levels than $\mathrm{ZnSO}_{4}$ alone, but the difference between these two fertilizers was not significant.

A decrease in the effectiveness of $\mathrm{Zn}$ application during the experiments was not detected. As a matter of fact, the greatest increases in $\mathrm{Zn}$ concentra- 
Table 51. Zinc concentration and uptake of timothy in two 2-year experiments as means of the four crops.

\begin{tabular}{|c|c|c|c|c|}
\hline \multirow[t]{2}{*}{ Treatment } & \multirow{2}{*}{$\begin{array}{l}\mathrm{Zn} \text { rate } \\
\mathrm{kg} \mathrm{ha}^{-1}\end{array}$} & \multicolumn{2}{|c|}{$\mathrm{Zn}$ concentration, $\mathrm{mg} \mathrm{kg}^{-1}$} & \multirow{2}{*}{$\begin{array}{c}\text { Zn uptake, } g \text { ha-1 } \\
\text { Mean }\end{array}$} \\
\hline & & Mean & Range & \\
\hline & & sen & Cl..... & \\
\hline 1. Control & 0 & $28.0^{c}$ & $25-31$ & 80 \\
\hline 2. $\mathrm{ZnSO}_{4}$ & 3 & $30.1^{\mathrm{bc}}$ & $27-34$ & 85 \\
\hline 3. 'Sinkkilannos' & 3 & $32.4^{\mathrm{abc}}$ & $29-34$ & 86 \\
\hline 4. 'Sinkkilannos', s.a.' & 3 & $31.9^{\mathrm{abc}}$ & $27-37$ & 87 \\
\hline 5. Coated NPK II, s.a. ${ }^{1}$ & $4 \times 0.75$ & $29.6^{\mathrm{bc}}$ & $25-32$ & 79 \\
\hline 6. $\mathrm{ZnSO}_{4}$ & 6 & $33.6^{\mathrm{ab}}$ & $31-37$ & 92 \\
\hline 7. 'Sinkkilannos' & 6 & $35.6^{a}$ & $33-38$ & 98 \\
\hline 8. 'Sinkkilannos', s.a. ${ }^{1}$ & 6 & $36.5^{a}$ & $36-38$ & 100 \\
\hline 9. NPK 18-3-12, s.a. ${ }^{1}$ & $4 \times 1.3$ & $29.5^{\mathrm{bc}}$ & $27-33$ & 82 \\
\hline 10. Coated NPK III, s.a.' & $4 \times 1.5$ & $34.1^{\text {ab }}$ & $31-37$ & 99 \\
\hline $\mathrm{HSD}_{0.05}$ (fertilizations) & & 5.3 & & 27 \\
\hline F (fertilizations) & & $5.612^{* *}$ & & $1.875^{\text {n.s. }}$ \\
\hline F (crops) & & $8.802^{* *}$ & & $152.840^{* *}$ \\
\hline 1. Control & 0 & $34.9^{\mathrm{cd}}$ & $32-40$ & $112^{a b c}$ \\
\hline 2. $\mathrm{ZnSO}_{4}$ & 3 & $35.9^{\mathrm{bcd}}$ & $30-41$ & $121^{\mathrm{abc}}$ \\
\hline 3. 'Sinkkilannos' & 3 & $40.0^{\mathrm{abc}}$ & $36-48$ & $122^{\mathrm{abc}}$ \\
\hline 4. 'Sinkkilannos', s.a.' & 3 & $38.9^{\mathrm{bcd}}$ & $34-46$ & $136^{\mathrm{ab}}$ \\
\hline 5. Coated NPK II, s.a.' & $4 \times 0.75$ & $34.1^{d}$ & $31-40$ & $100^{\mathrm{s}}$ \\
\hline 6. $\mathrm{ZnSO}_{4}$ & 6 & $37.6^{\text {bed }}$ & $34-44$ & $124^{\mathrm{abc}}$ \\
\hline 7. 'Sinkkilannos' & 6 & $41.0^{\mathrm{ab}}$ & $36-47$ & $126^{\mathrm{abe}}$ \\
\hline 8. 'Sinkkilannos', s.a.' & 6 & $44.6^{a}$ & $37-55$ & $140^{\mathrm{a}}$ \\
\hline 9. NPK 18-3-12, s.a. ${ }^{1}$ & $4 \times 1.3$ & $34.3^{\mathrm{d}}$ & $30-38$ & $103^{\mathrm{bc}}$ \\
\hline 10. Coated NPK III, s.a.' & $4 \times 1.5$ & $35.2^{\mathrm{cd}}$ & $32-41$ & $108^{\mathrm{abc}}$ \\
\hline $\mathrm{HSD}_{0.05}$ (fertilizations) & & 5.3 & & 35.5 \\
\hline F (fertilizations) & & $9.193^{* *}$ & & $2.937^{* *}$ \\
\hline F (crops) & & $41.960^{* * *}$ & & $35.745^{* * *}$ \\
\hline
\end{tabular}

's.a. = surface application

tion of grass occurred in the last crop harvested. The effect of a given $\mathrm{Zn}$ rate was similar in both soils. As the mean of the two experiments, 'Sinkkilannos' increased plant $\mathrm{Zn}$ concentration by 4.4 and $8.5 \mathrm{mg} \mathrm{kg}^{-1}$ at the application rate of 3 and $6 \mathrm{~kg} \mathrm{Zn} \mathrm{ha}^{-1}$, respectively, corresponding to an increase of $1.4 \mathrm{mg} \mathrm{kg}^{-1}$ for each kilogram of $\mathrm{Zn}$ applied.

Cumulative $\mathrm{Zn}$ uptake in the four crops $(4 \times$ the means in Table 51) was $317-399 \mathrm{~g} \mathrm{ha}^{-1}$ and 400 $561 \mathrm{~g} \mathrm{ha}^{-1}$ in clay and fine sand, respectively. Some treatments seemed to increase $\mathrm{Zn}$ uptake by the crop but in neither soil did any of the treatments differ significantly from the control. The apparent utilization of fertilizer $\mathrm{Zn}$ corresponded to 0.8 $1.5 \%$ of added $\mathrm{Zn}$ in the treatments where the $\mathrm{Zn}$ concentration of the grass was significantly elevated.

Soil analyses carried out at the end of the experiments showed that $\mathrm{Zn}$ applications yielded slightly elevated $\mathrm{Zn}_{\mathrm{Ac}}$ in clay $\left(\mathrm{F}=12.584^{* * *}\right)$. Owing to a large variation of the results in fine sand, the influence of $\mathrm{Zn}$ application on $\mathrm{Zn}_{\mathrm{Ac}}$ was not significant $\left(\mathrm{F}=1.742^{\text {n.s. }}\right)$. Surface-application of granular $\mathrm{Zn}$ containing fertilizers may have caused an uneven distribution of $\mathrm{Zn}$ in the soil, possibly resulting in a 
failure of representative sampling. The means of $\mathrm{Zn}_{\mathrm{Ac}}\left(\mathrm{mg} \mathrm{dm}^{-3}\right)$ at the various levels of added $\mathrm{Zn}$, tested separately in clay and fine sand, were as follows:

$\begin{array}{lll}\mathrm{Zn}, \mathrm{kg} \mathrm{ha}^{-1} & \text { Clay } & \text { Fine sand } \\ 0 & 1.2^{\mathrm{b}} & 2.8 \\ 3 & 1.4^{\mathrm{b}} & 3.3 \\ 6 & 2.0^{\mathrm{a}} & 3.5\end{array}$

\subsection{Comparison of $\mathrm{Zn}$ fertilizers, $\mathrm{Zn}$ rates and application practices with barley}

\subsubsection{Different fertilizers as $\mathrm{Zn}$ sources for barley}

The growth of barley was ample in 1990 and 1991, but in 1992 the yields were reduced in clay by the drought (Table 52). In none of the experiments were grain or straw yields affected by $\mathrm{Zn}$ fertilization.

Zinc concentration of grain and straw (Table 53) was the highest in mull which had the lowest $\mathrm{pH}$ and highest content of $\mathrm{Zn}_{\mathrm{Ac}}$. Inversely, the lowest concentrations occurred in barley grown in fine sand which had the highest $\mathrm{pH}$ and was poorest in $\mathrm{Zn}_{\text {Ac. }}$. Zinc concentration of grain was, with few exceptions, at least twice the $\mathrm{Zn}$ concentration of the straw. Foliar application of Na2Zn-EDTA elevated $\mathrm{Zn}$ concentration of grain and straw significantly in all experiments. The increase in $\mathrm{Zn}$ concentration of grain was $4.3,3.7$ and $4.5 \mathrm{mg} \mathrm{kg}^{-1}$ in clay, mull and fine sand, respectively. In mull and fine sand, none of the soil-applied $\mathrm{Zn}$ fertilizers affected $\mathrm{Zn}$ concentration of grain or straw. On the contrary, in clay all soil-applied $\mathrm{Zn}$ fertilizers, except $\mathrm{Na}_{2} \mathrm{Zn}$-EDTA mixed in the soil, elevated $\mathrm{Zn}$ concentration of the grain and the two $\mathrm{Zn}$-containing NPK fertilizers increased $\mathrm{Zn}$ concentration of the straw. No systematic difference could be detected in the effect of $\mathrm{Zn}$ fertilizers applied in the soil annually and that applied only at the beginning of the experiment. It should be pointed out that the $\mathrm{Zn}$ concentration of the crop did not correlate with
Table 52. Grain and straw yield $\left(\mathrm{kg} \mathrm{ha}^{-1}\right)$ of barley in three field experiments.

\begin{tabular}{lcccc}
\hline \multirow{2}{*}{ Yield } & Year & \multicolumn{3}{c}{ Yield $\left(\mathrm{kg} \mathrm{ha}^{-1}\right)$ obtained from } \\
\cline { 3 - 5 } & & Clay & Mull & Fine sand \\
\hline Grain' & 1990 & 4597 & 6361 & 6996 \\
& 1991 & 5222 & 5604 & 6414 \\
& 1992 & 1790 & 7051 & 5514 \\
Straw & 1991 & 2456 & 3435 & 3236 \\
& 1992 & 660 & 2782 & 3040 \\
\hline
\end{tabular}

${ }^{1}$ Grain yields are presented at the moisture of $15 \%$.

Table 53. Mean $\mathrm{Zn}$ concentration of barley grains and straw in three 3-year field experiments in which different $\mathrm{Zn}$ fertilizers were applied at the rate of $5.4 \mathrm{~kg} \mathrm{ha}^{-1}\left(4.8 \mathrm{~kg} \mathrm{ha}^{-1}\right.$ in NPK 18-3-12).'

\begin{tabular}{|c|c|c|c|}
\hline \multirow[t]{2}{*}{ Treatment } & \multicolumn{3}{|c|}{$\begin{array}{l}\mathrm{Zn} \text { concentration }\left(\mathrm{mg} \mathrm{kg}^{-1}\right) \\
\text { in yield obtained from }\end{array}$} \\
\hline & Clay & Mull & Fine sand \\
\hline & & Grain & \\
\hline Control & $29.3^{b}$ & $39.4^{b}$ & $17.6^{b}$ \\
\hline $\mathrm{ZnSO}_{4}{ }^{2}$ & $33.3^{\mathrm{a}}$ & $39.4^{b}$ & $18.3^{b}$ \\
\hline 'Sinkkilannos'2 & $33.8^{\mathrm{a}}$ & $40.3^{b}$ & $18.6^{b}$ \\
\hline $\mathrm{Na}_{2} \mathrm{Zn}$-EDTA in soil ${ }^{3}$ & $32.9^{\mathrm{ab}}$ & $39.2^{\mathrm{b}}$ & $18.2^{\mathrm{b}}$ \\
\hline NPK $18-3-12^{3}$ & $34.2^{\mathrm{a}}$ & $39.6^{b}$ & $19.1^{\mathrm{ab}}$ \\
\hline Coated NPK I ${ }^{3}$ & $34.5^{a}$ & $39.6^{b}$ & $16.5^{\mathrm{b}}$ \\
\hline $\mathrm{Na}_{2} \mathrm{Zn}$-EDTA, foliar ${ }^{3}$ & $33.6^{\mathrm{a}}$ & $43.1^{\mathrm{a}}$ & $22.1^{\mathrm{a}}$ \\
\hline $\mathrm{HSD}_{0.05}$ & 4.0 & 2.9 & 3.5 \\
\hline F (treatments) & $3.504^{* *}$ & $4.086^{* *}$ & $4.568^{* * *}$ \\
\hline F (years) & $37.251^{\cdots}$ & $10.783^{* *}$ & $2.849^{\text {n.s. }}$ \\
\hline Control & $11.0^{b}$ & $17.9^{b}$ & $5.6^{\mathrm{b}}$ \\
\hline $\mathrm{ZnSO}_{4}{ }^{2}$ & $14.5^{\mathrm{ab}}$ & $15.8^{\mathrm{b}}$ & $6.8^{\mathrm{ab}}$ \\
\hline 'Sinkkilannos'2 & $12.9^{\mathrm{ab}}$ & $17.6^{b}$ & $6.2^{b}$ \\
\hline $\mathrm{Na}_{2} \mathrm{Zn}$-EDTA in soil ${ }^{3}$ & $12.9^{\mathrm{ab}}$ & $18.7^{b}$ & $6.0^{b}$ \\
\hline NPK $18-3-12^{3}$ & $15.2^{\mathrm{a}}$ & $18.7^{\mathrm{b}}$ & $7.1^{\mathrm{ab}}$ \\
\hline Coated NPK I ${ }^{3}$ & $16.0^{\mathrm{a}}$ & $17.5^{b}$ & $6.2^{\mathrm{b}}$ \\
\hline $\mathrm{Na}_{2} \mathrm{Zn}$-EDTA, foliar ${ }^{3}$ & $16.6^{\mathrm{a}}$ & $25.9^{\mathrm{a}}$ & $9.8^{\mathrm{a}}$ \\
\hline $\mathrm{HSD}_{0.05}$ & 4.1 & 6.1 & 3.3 \\
\hline F (treatments) & $4.189^{* *}$ & $5.189^{* *}$ & $3.425^{* *}$ \\
\hline $\mathrm{F}$ (years) & $7.344^{* *}$ & $71.063^{\cdots *}$ & $7.194^{* *}$ \\
\hline
\end{tabular}

${ }^{1}$ Results of grain and straw were tested separately in each soil.

${ }^{2}$ Applied only at the beginning of the experiment.

${ }^{3}$ Applied each year at the rate of $1.8 \mathrm{~kg} \mathrm{Zn} \mathrm{ha}^{-1}\left(1.6 \mathrm{~kg} \mathrm{ha}^{-1}\right.$ in NPK 18-3-12).

dry matter yield. For example, in clay the highest yield in 1991 and the lowest one in 1992 had similar $\mathrm{Zn}$ concentrations in grain (mean of all plots 36.1 
and $34.2 \mathrm{mg} \mathrm{kg}^{-1}$ in 1991 and 1992, respectively) and straw (12.4 and $14.4 \mathrm{mg} \mathrm{kg}^{-1}$, respectively).

In the three years, $\mathrm{Zn}$ concentration of grain of the control plots varied within a narrow range $(3 \mathrm{mg}$ $\mathrm{kg}^{-1}$ in clay and mull, $1 \mathrm{mg} \mathrm{kg}^{-1}$ in fine sand). In clay there was substantial annual variation in $\mathrm{Zn}$ concentration of grain in the plots fertilized with $\mathrm{Zn}$. In the first experimental year, $\mathrm{Zn}$ concentration was below $30 \mathrm{mg} \mathrm{kg}^{-1}$ in all treatments, while in the two following years the average concentrations of the different treatments ranged from 32 to $38 \mathrm{mg}$ $\mathrm{kg}^{-1}$. The annual variation of straw $\mathrm{Zn}$ concentration was by far the greatest in mull where the means were $27.4,11.6$ and $14.2 \mathrm{mg} \mathrm{kg}^{-1}$ in 1990, 1991 and 1992, respectively, in plots other than those of $\mathrm{Na} 2 \mathrm{Zn}$-EDTA application. In clay and fine sand the annual variation in $\mathrm{Zn}$ concentration of straw was less marked.

The mean annual $\mathrm{Zn}$ uptake by barley grains was 89,212 and $94 \mathrm{~g} \mathrm{ha}^{-1}$ in the control plots of clay, mull and fine sand, respectively. In clay, all $\mathrm{Zn}$ fertilizers slightly increased $\mathrm{Zn}$ uptake but only the Coated NPK I gave rise to a significant increase (24 $\mathrm{g} \mathrm{ha}^{-1},+27 \%$ ). In fine sand, foliar application of $\mathrm{Na} 2 \mathrm{Zn}$-EDTA elevated $\mathrm{Zn}$ uptake significantly (by $23 \mathrm{~g} \mathrm{ha}^{-1},+24 \%$ ); utilization of foliar-applied $\mathrm{Zn}$ in grain was $1.3 \%, 0.6 \%$ and $0.8 \%$ in clay, mull and fine sand, respectively. Mean annual $\mathrm{Zn}$ uptake by the straw in the control plots was 15,42 and $17 \mathrm{~g}$ $\mathrm{ha}^{-1}$ in clay, mull and fine sand, respectively. Foliar application of $\mathrm{Na}_{2} \mathrm{Zn}$-EDTA increased the quantity of $\mathrm{Zn}$ harvested in the straw by 12,21 and $18 \mathrm{~g} \mathrm{ha}^{-1}$ in clay, mull and fine sand, respectively, corresponding to $0.7-1.1 \%$ of the foliar-applied $\mathrm{Zn}$.

\subsubsection{Plant $\mathrm{Zn}$ concentration as affected by different $\mathrm{Zn}$ rates}

Zinc application of 15 or $30 \mathrm{~kg} \mathrm{Zn} \mathrm{ha}^{-1}$ did not affect the dry matter yields at any growth stage, and only the means of the dry matter produced at different growth stages are presented (Table 54). There was a decreasing trend in $\mathrm{Zn}$ concentration of vegetative plant material in the course of the growing season (Table 55). In 1991, Zn concentrations in the samples taken at the Feekes 2 and 5 growth stages were higher than in the vegetative parts of the plants at later growth stages in both soils. In 1992, the samples taken at Feekes 2 growth stage had a significantly higher $\mathrm{Zn}$ concentration than the vegetative parts of the later growth stages. The higher $\mathrm{Zn}$ concentration in grain, as compared to that of straw, suggests an effective translocation of $\mathrm{Zn}$ from the vegetative parts. The phenomenon was pronounced in fine sand where $\mathrm{Zn}$ concentration of the straw was extremely low in 1992. Even though $\mathrm{Zn}_{\mathrm{Ac}}$ was of the same magnitude in both soils, $\mathrm{Zn}$ concentration of barley at any growth stage was higher in clay soil than in fine sand which had a higher $\mathrm{pH}$.

In clay, $\mathrm{Zn}$ application elevated $\mathrm{Zn}$ concentration of barley only in the first experimental year $(\mathrm{F}=$ $12.503^{* * *}$ ) and showed no residual effect in the second year. In fine sand where $\mathrm{Zn}$ application of $5.4 \mathrm{~kg} \mathrm{ha}^{-1}$ to the soil (see Section 5.3.1) did not affect $\mathrm{Zn}$ concentration of barley, the higher rates in the present experiment had a significant effect in the first year $\left(\mathrm{F}=19.820^{* * *}\right)$ and there was an increase in plant $\mathrm{Zn}$ concentration $\left(\mathrm{F}=4.107^{* *}\right)$

Table 54. Dry matter yields $\left(\mathrm{kg} \mathrm{ha}^{-1}\right)$ produced by barley at different growth stages in two field experiments.

\begin{tabular}{lccccc}
\hline Soil and year & \multicolumn{5}{c}{ Growth stage } \\
\cline { 2 - 6 } & Feekes 2 & Feekes 5 & Feekes 10.5 & Grain' & Straw' \\
\hline Clay: & 655 & 3579 & 5419 & - & 2346 \\
1991 & 587 & 1201 & 3113 & & 5483 \\
1992 & & & & 5146 & 4814 \\
Fine sand: & 1942 & 4399 & 7420 & 5861 & 4391 \\
1991 & 1012 & 3058 & & & \\
1992 & & & & & \\
\hline
\end{tabular}

1 The grain and straw samples of 1991 from the experiment on the clay soil were destroyed by fire. 
Table 55. Zinc concentration and uptake of barley at different growth stages in two field experiments. I, II and III refer to the plant samples taken at Feekes 2, 5 and 10.5 growth stages, respectively. ${ }^{1}$

\begin{tabular}{|c|c|c|c|c|c|c|c|}
\hline \multirow{2}{*}{$\begin{array}{l}\text { Soil } \\
\text { and year }\end{array}$} & \multirow{2}{*}{$\begin{array}{l}\text { Zn application, } \\
\mathrm{kg} \mathrm{ha}^{-1}\end{array}$} & \multicolumn{5}{|c|}{$\mathrm{Zn}\left(\mathrm{mg} \mathrm{kg}^{-1}\right)$ at various growth stages } & \multirow{2}{*}{$\begin{array}{l}\mathrm{Zn} \text { uptake }\left(\mathrm{g} \mathrm{ha}^{-1}\right) \\
\text { at maturity }\end{array}$} \\
\hline & & 1 & II & III & Grain & Straw & \\
\hline \multirow[t]{4}{*}{ Clay 1991} & 0 & $37.8^{\mathrm{b}}$ & $31.8^{\mathrm{b}}$ & 18.3 & - & - & $106^{2}$ \\
\hline & 15 & $52.9^{\mathrm{a}}$ & $49.0^{\mathrm{ab}}$ & 25.0 & - & - & $132^{2}$ \\
\hline & 30 & $58.3^{\mathrm{a}}$ & $53.3^{\mathrm{a}}$ & 25.3 & - & - & $139^{2}$ \\
\hline & $\mathrm{HSD}_{0.05}$ & 11.8 & 20.9 & 8.3 & & & 51 \\
\hline \multirow[t]{4}{*}{ Clay 1992} & 0 & 29.2 & 23.3 & 21.6 & 32.0 & 14.1 & 98 \\
\hline & 15 & 27.7 & 23.8 & 21.3 & 36.8 & 15.9 & 110 \\
\hline & 30 & 28.3 & 24.5 & 21.2 & 36.0 & 16.6 & 118 \\
\hline & $\mathrm{HSD}_{0.05}$ & 16.0 & 5.0 & 4.8 & 5.6 & 6.0 & 61 \\
\hline Fine sand & 0 & $27.4^{b}$ & 20.3 & 8.1 & $14.6^{\mathrm{b}}$ & 4.7 & $101^{b}$ \\
\hline \multirow[t]{3}{*}{1991} & 15 & $31.9^{\mathrm{ab}}$ & 37.0 & 10.5 & $19.6^{\mathrm{a}}$ & 8.1 & $142^{\mathrm{ab}}$ \\
\hline & 30 & $35.6^{\mathrm{a}}$ & 43.5 & 11.3 & $21.8^{\mathrm{a}}$ & 11.4 & $185^{\mathrm{a}}$ \\
\hline & $\mathrm{HSD}_{0.05}$ & 5.1 & 40.3 & 3.5 & 4.6 & 7.8 & 54 \\
\hline Fine sand & 0 & 21.9 & 15.5 & 10.6 & 16.9 & 2.6 & 113 \\
\hline \multirow[t]{3}{*}{1992} & 15 & 22.5 & 16.7 & 13.0 & 18.1 & 3.2 & 118 \\
\hline & 30 & 22.9 & 18.3 & 13.4 & 19.9 & 3.7 & 128 \\
\hline & $\mathrm{HSD}_{0.05}$ & 7.0 & 3.7 & 6.0 & 8.0 & 1.7 & 24 \\
\hline
\end{tabular}

1 Zinc concentration and uptake were tested separately in each soil, each year and growth stage.

${ }^{2}$ In 1991, Zn uptake in the clay soils refers to the sampling at Feekes 10.5 growth stage.

also in the second year. In neither of the soils did $\mathrm{Zn}$ concentration of the plants at $\mathrm{Zn}$ rate $15 \mathrm{~kg} \mathrm{ha}^{-1}$ differ from that at $\mathrm{Zn}$ rate $30 \mathrm{~kg} \mathrm{ha}^{-1}$. The utilization of applied $\mathrm{Zn}$ was extremely low, $0.2-0.3 \%$. When the plant $\mathrm{Zn}$ concentrations were compared separately at each sampling (Table 55), the differences between the $\mathrm{Zn}$ rates were not always statistically significant even in the first year, owing to large variation in the $\mathrm{Zn}$ concentration of plants fertilized with $\mathrm{Zn}$. The influence of $\mathrm{Zn}$ application on $\mathrm{Zn}$ concentration of barley was greater in the early growth stages than later in the growing season (Feekes 10.5), reflecting the accumulation of dry matter and suggesting that $\mathrm{Zn}$ was taken up at the early part of the growing season.

Soil analyses at the end of the experiments showed that the effect of the application of high rates of $\mathrm{ZnSO}_{4}$ on soil $\mathrm{Zn}_{\mathrm{Ac}}$ was rather small and statistically insignificant both in clay $\left(\mathrm{F}=1.554^{\mathrm{n} . \mathrm{s}}\right.$. and in fine sand $\left(\mathrm{F}=2.298^{\text {n.s. }}\right)$. The means of $\mathrm{Zn}_{\mathrm{Ac}}$ $\left(\mathrm{mg} \mathrm{dm}^{-3}\right)$ at the different levels of added $\mathrm{Zn}$, tested separately in clay and fine sand, were as follows:

$\begin{array}{ccc}\mathrm{Zn}, \mathrm{kg} \mathrm{ha}^{-1} & \text { Clay } & \text { Fine sand } \\ 0 & 3.5 & 1.9 \\ 15 & 2.9 & 2.5 \\ 30 & 6.0 & 3.8\end{array}$

\subsection{Discussion}

The status of $\mathrm{Zn}_{\mathrm{Ac}}$ of the mineral soils where the field experiments were carried out was far below the average $\mathrm{Zn}_{\mathrm{Ac}}$ of cultivated soils of Finland (SIPPOLA and TARES 1978 and unpublished data of Soil Analysis Service Ltd.). In spite of the rather low $\mathrm{Zn}_{\mathrm{Ac}}$ concentration, timothy did not show any signs of $\mathrm{Zn}$ deficiency and had a $\mathrm{Zn}$ concentration similar to the mean value in samples collected from various parts of Finland (KÄHÄRI and NISSINEN 1978). Also $\mathrm{Zn}$ concentration of barley grains was well beyond the deficiency level in clay and especially in mull where the abundant $\mathrm{Zn}_{\mathrm{Ac}}$ reserves in the subsoil may have contributed to the high $\mathrm{Zn}$ 
concentration in barley grains. The sufficient supply of $\mathrm{Zn}$ from soil reserves explains the absent response of timothy and barley yields to added $\mathrm{Zn}$. In the control plots of fine sand, $\mathrm{Zn}$ concentration of barley grains was below $20 \mathrm{mg} \mathrm{kg}^{-1}$ but the growth was probably not limited by $\mathrm{Zn}$ deficiency because the yield was not increased by $\mathrm{Zn}$ applications. Moreover, the higher $\mathrm{Zn}$ concentration earlier in the growing season suggests that $\mathrm{Zn}$ supply for barley was at a very sufficient level during the intensive growth also in the fine sand.

The efficiency of $\mathrm{ZnSO}_{4}$ to increase $\mathrm{Zn}$ concentration of timothy was similar to that observed in other field experiments carried out with forage grasses in acid mineral soils. For example, in two mineral soils (pH 5.6 and 5.8) in New Zealand (McLAREN et al. 1991) an application of $4.6 \mathrm{~kg} \mathrm{ha}^{-1}$ as $\mathrm{ZnSO}_{4}$ increased $\mathrm{Zn}$ concentration of herbage by $8.9 \mathrm{mg} \mathrm{kg}^{-1}$. In the experiments of JAAKKOLA and VOGT (1978) in Finland the increase of $\mathrm{Zn}$ concentration of hay in the first experimental year corresponded to $1.3 \mathrm{mg} \mathrm{kg}^{-1}$ for each kilogram of $\mathrm{Zn}$ applied, which agrees with the results of the present study. The response of plant $\mathrm{Zn}$ concentration is, however, strongly dependent on soil characteristics. The studies of URVAS $(1986,1992)$ on $\mathrm{Zn}$ fertilization of timothy show that the efficiency of fertilizer $\mathrm{Zn}$ can be much higher in strongly acid peat soil, and even a small application of $\mathrm{Zn}$ $\left(0.55 \mathrm{~kg} \mathrm{ha}^{-1}\right)$ may elevate plant $\mathrm{Zn}$ concentration significantly.

The low or absent response of $\mathrm{Zn}$ concentration of barley grains to 4.8 or $5.4 \mathrm{~kg} \mathrm{Zn} \mathrm{ha}^{-1}$ applied to soil is in agreement with other Finnish field experiments where small rates $\left(1.75 \mathrm{~kg} \mathrm{ha}^{-1}\right)$ of $\mathrm{Zn}$ have been given (JAAKKOLA and VOGT 1978, SYVÄLAHTI and KORKMAN 1978). A higher Zn application ( 15 and $30 \mathrm{~kg} \mathrm{ha}^{-1}$ ) elevated $\mathrm{Zn}$ concentration of barley significantly in fine sand, but even then $\mathrm{Zn}$ concentration of grain remained around $20 \mathrm{mg}$ $\mathrm{kg}^{-1}$, reflecting the poor availability of $\mathrm{Zn}$ in neutral soil. However, the response was of the same level as has been observed in the neutral and slightly acid mineral soils of Norway and Canada where 50 and $20 \mathrm{~kg} \mathrm{Zn} \mathrm{ha}^{-1}$, respectively, were applied to barley (MYHR 1988, GUPTA 1989).

The drought in 1992 may partly explain the small residual effect of the high $\mathrm{Zn}$ rates $(15$ and $30 \mathrm{~kg}$ $\mathrm{ha}^{-1}$ ) on barley. In the first year of the experiment (1991), there was plenty of rain in May and June, and the roots of barley were probably active in the plough layer, resulting in the observed response to applied $\mathrm{Zn}$. Owing to the drought in the second year (1992), the plough layer was dry and plant roots were able to take up nutrients from that part of the soil less effectively. In 1992, the roots probably grew to a greater extent into the deeper soil layers where they were no more in contact with the applied $\mathrm{Zn}$. This hypothesis is supported by the findings made in Canada by DWYER et al. (1988) according to which the maximum rooting depth of barley and the quantity of roots in the deeper soil layers increase when there is shortage of water in the surface soil. The hypothesis does not, however, explain why there was some response by barley to soil-applied $\mathrm{Zn}$ also in 1992 in clay soil in the other experiment where the different $\mathrm{Zn}$ fertilizers were tested (Section 5.3.1).

Granulation and spot-placement commonly decrease the agronomic efficiency of $\mathrm{ZnSO}_{4}$ added to neutral and calcareous soils (BROWN and KRANTZ 1966, Allen and TERMAN 1967, MORTVEDT and GIORDANO 1969a). However, in the present study, carried out in acid soils, the granulated 'Sinkkilannos' mixed into the soil elevated plant $\mathrm{Zn}$ concentration at the same rate as did $\mathrm{ZnSO}_{4}$. In the granulated product, $\mathrm{ZnSO}_{4}$ is incorporated in gypsum, and $\mathrm{Zn}$ cations seem to be readily released from the matrix into the soil solution. Also the top-dressed 'Sinkkilannos' increased $\mathrm{Zn}$ concentration of grass in the field and pot experiments at least as effectively as did the fertilizer mixed in the soil. Availability of $\mathrm{Zn}$ in granular fertilizers added onto the soil surface requires that $\mathrm{Zn}$ be dissolved from the granule and further to move into the soil and to get into contact with active plant roots. The rains in the early summer of 1991 right after broadcasting the fertilizers or the daily watering in the pot experiment probably resulted in an effective disintegration of the granules of 'Sinkkilannos' and enhanced the penetration of $\mathrm{Zn}$ into the root zone. In a shortterm pot experiment, top-dressing retarded the fertilizer effect of 'Sinkkilannos', but in the field there was evidently enough time for the surface-applied 
granules of 'Sinkkilannos' to dissolve before the first harvest, and consequently there was no difference between the application methods.

The negligible agronomic efficiency of $\mathrm{Zn}$ contained in NPK fertilizers cannot solely be attributed to the granular form of the fertilizers because the granular 'Sinkkilannos' did elevate plant Zn concentration in the very same experiments. The low efficiency is rather due to the chemical reactions occurring in the fertilizer between $\mathrm{Zn}$ and the other components. During the manufacturing process of the present NPK fertilizers the acid orthophosphate slurry is ammoniated (KIVIOJA 1987), resulting in an elevation of $\mathrm{pH}$. The accompanying decrease in the water-solubility and plant-availability of $\mathrm{Zn}$ added to the fertilizer as $\mathrm{ZnSO}_{4}$ (MORTVEDT 1968, MORTVEDT and GioRDANO 1969b) is due to the precipitation of insoluble $\mathrm{Zn}$ compounds (e.g. $\mathrm{Zn}$ phosphates, $\mathrm{Zn}$ hydroxides) in the fertilizer grain (TERMAn et al. 1966, Allen and TERMAn 1967, MORTVEDT and GIORDANO 1969a). According to MORTVEDT (1968), above pH 5 the availability of $\mathrm{Zn}$ in ammoniated orthophosphate fertilizers is less than $20 \%$ of what is observed when $\mathrm{ZnSO}_{4}$ is applied separately or incorporated in unammoniated ( $\mathrm{pH}$ 3) orthophosphate fertilizer. The $\mathrm{pH}$ of the present NPK fertilizers ranged between 5.0 and 5.4, suggesting a low water-solubility of $\mathrm{Zn}$ in the fertilizer. The present field and pot experiments showed that the sparingly soluble $\mathrm{Zn}$ compounds are not necessarily dissolved during short-term experiments even in acid soils, resulting in an inconsistent fertilizer effect. Because the NPK fertilizers coated with $\mathrm{ZnSO}_{4}$ had an equally low availability of $\mathrm{Zn}$, it is likely that ionic activities also in the vicinity of the fertilizer granule exceed the solubility products of sparingly soluble $\mathrm{Zn}$ compounds.

The current results disagree with those of SILLANPÄÄ (1990) who applied Zn-containing NPK fertilizers to barley in ten field experiments in Finland. In those experiments, high $\mathrm{Zn}$ rate $(11.6 \mathrm{~kg}$ $\left.\mathrm{ha}^{-1}\right)$ and low soil $\mathrm{pH}\left(\mathrm{CaCl}_{2}-\mathrm{pH} 4.2-5.5\right)$ probably facilitated the mean increase of $8 \mathrm{mg} \mathrm{kg}^{-1}$ in grain $\mathrm{Zn}$ concentration. Moreover, in the fertilizers of SILLANPÄÄ, part of $\mathrm{Zn}\left(2 \mathrm{~kg} \mathrm{ha}^{-1}\right)$ had been added as Zn-EDTA. According to MORTVEDT and GIORDANO (1969a), the plant-availability of $\mathrm{Zn}$ added as $\mathrm{Zn}$-EDTA in macronutrient fertilizers is not reduced as much as that of $\mathrm{ZnSO}_{4}$.

Increased $\mathrm{Zn}$ concentration of barley straw by foliar sprays of $\mathrm{Na}_{2} \mathrm{Zn}$-EDTA can at least partly be caused by the adsorption of foliar-applied $\mathrm{Zn}$ on the surfaces of plant leaves. Therefore the increased $\mathrm{Zn}$ concentration of straw by this treatment must not be considered an indication of high fertilizer efficiency. Because Na2Zn-EDTA was sprayed at an early growth stage before there was any shoot or ear in the crop, the increase of grain $\mathrm{Zn}$ concentration can be attributed to the introduction of applied $\mathrm{Zn}$ into the physiological reactions of the plant. However, soil pH strongly dominated the grain $\mathrm{Zn}$ concentration also in this treatment. In some studies application of $\mathrm{Zn}$ in a chelated form to neutral or calcareous soils has been at least twice as effective as application of $\mathrm{ZnSO}_{4}$ (MORTVEDT and GIORDANO 1969a, BOAWN 1973, HERGERT et al. 1984). The difference between the two sources has not been significant in acid soils (HERGERT et al. 1984) and not always even in neutral soils (SCHNAPPINGER et al. 1972). Also in the present study, the soil-applied $\mathrm{Na} 2 \mathrm{Zn}$-EDTA failed to increase plant $\mathrm{Zn}$ concentration, which shows that the observed effect of foliar application of $\mathrm{Na}_{2} \mathrm{Zn}$-EDTA can be attributed primarily to the application method rather than to the chelated form of $\mathrm{Zn}$. This conclusion is supported indirectly by the results of PATERSON et al. (1991) who elevated $\mathrm{Zn}$ concentration of barley grains with foliar sprays of $\mathrm{ZnSO}_{4}$, while the application of $\mathrm{ZnSO}_{4}$ to the soil was without effect. Further, it needs to be pointed out that foliar application of $\mathrm{Na}_{2} \mathrm{Zn}$-EDTA was the only treatment increasing $\mathrm{Zn}$ concentration of barley grain in fine sand where insufficient $\mathrm{Zn}$ supply to barley may have been approached. 


\section{GENERAL DISCUSSION AND CONCLUSIONS}

In spite of generally sufficient $\mathrm{Zn}$ reserves for plant growth the present material contained a few soils poor in $\mathrm{Zn}$. Even though worldwide zinc deficiency is commonly connected to calcareous soils, low plant-availability of $\mathrm{Zn}$ may occur also in slightly acid and neutral mineral soils of Finland. Moreover, the soil testing method applied in Finland (AAAc-EDTA, pH 4.65) seems to overestimate the $\mathrm{Zn}$ supply to plants in these soils. However, the soils with the scarcest reserves were among Carex peat and Ligno Carex peat soils, which were poor in $\mathrm{Zn}$ also according to international comparisons. Owing to the small number of organogenic soils in the present material, it is not possible to draw conclusions on the geographic occurrence of $\mathrm{Zn}$ deficiency in Finland even though cultivated peat soils are the most common in the northern parts of the country. Peat soils constitute less than $10 \%$ of the cultivated area of Finland (KURKI 1982), but they are not all poor in $\mathrm{Zn}$. Only $1.5 \%$ of samples analyzed for $\mathrm{Zn}_{\mathrm{Ac}}$ in soil testing in $1986-1988$ contained $\mathrm{Zn}_{\mathrm{Ac}}$ less than $1.0 \mathrm{mg} \mathrm{dm}^{-3}$ (unpublished data of Soil Analysis Service Ltd.) and were rated poor in $\mathrm{Zn}$ according to the current interpretation (Viljavuuspalvelu 1992). The present results as well as those of URVAS $(1985,1990)$ suggest that yield response to applied $\mathrm{Zn}$ is hardly observed in short-term experiments even in these soils. Consequently, a $\mathrm{Zn}_{\mathrm{Ac}}$ concentration below $1.0 \mathrm{mg} \mathrm{dm}^{-3}$ in the soil does not necessarily indicate insufficient $\mathrm{Zn}$ supply to the crop. In accordance with the results of soil analyses and pot experiments, yield increases owing to $\mathrm{Zn}$ fertilization have not been detected in the field in Finland. Therefore, $\mathrm{Zn}$ fertilization in the great majority of cultivated soils of Finland is justified by the possible elevation of $\mathrm{Zn}$ concentration of the crop.

It seems feasible that in the poorest peat soils $\mathrm{Zn}$ reserves can be exhausted over time in intensive grassland cultivation. In the studies of SILLANPÄÄ and RINNE (1975) the quantity of Zn harvested in three cuttings of silage grass amounted to $280 \mathrm{~g} \mathrm{ha}^{-1}$ at the annual $\mathrm{N}$ fertilizer level of $300 \mathrm{~kg} \mathrm{ha}^{-1}$. At this rate, the uptake of $\mathrm{Zn}$ in 10 years amounts to $2.8 \mathrm{~kg}$ $\mathrm{ha}^{-1}$, or $1.4 \mathrm{mg} \mathrm{dm}^{-3}$ in a $20-\mathrm{cm}$ layer. This corres- ponds to the reserves of secondary $\mathrm{Zn}$ in the poorest peat soils. Low $\mathrm{pH}$ of most peat soils further contributes to the high availability and effective utilization of soil $\mathrm{Zn}$. The above calculation supports the recent finding by ERVIÖ et al. (1990) of the decline of $\mathrm{Zn}_{\mathrm{Ac}}$ in the cultivated soils of northern Finland.

Soil characteristics strongly affect the response of plant $\mathrm{Zn}$ concentration to $\mathrm{Zn}$ fertilization. In strongly acid soils $\mathrm{Zn}$ application elevates $\mathrm{Zn}$ concentration of grass, also facilitating the maintenance of sufficient supply of $\mathrm{Zn}$ to plants in peat soils under intensive grassland cultivation. But even high rates of $\mathrm{Zn}$ to slightly acid and neutral soils elevate the $\mathrm{Zn}$ content of the crop less effectively even if the soils were poor in $\mathrm{Zn}_{\mathrm{Ac}}$. In those soils, foliar sprays increase plant $\mathrm{Zn}$ concentration more effectively. In order to avoid applications of $\mathrm{Zn}$ to soil with no fertilizer effect, both soil $\mathrm{pH}$ and $\mathrm{Zn}_{\mathrm{Ac}}$ need to be taken into consideration when $\mathrm{Zn}$ fertilizer recommendations are given. Owing to the inconsistent effect of Zn-containing NPK fertilizers on $\mathrm{Zn}$ concentration of crop, the use of separate $\mathrm{Zn}$ fertilizers should be preferred.

The reserves of secondary $\mathrm{Zn}\left(10-20 \mathrm{~kg} \mathrm{ha}^{-1}\right.$ in a $20-\mathrm{cm}$ deep plough layer) were of the same magnitude as $\mathrm{Zn}$ fertilizer recommendations $(5-20 \mathrm{~kg}$ $\mathrm{Zn} \mathrm{ha}{ }^{-1}$, Viljavuuspalvelu 1992). The utilization of added $\mathrm{Zn}$ is commonly far below $5 \%$ and therefore the recommended application substantially increases the reserves of secondary $\mathrm{Zn}$ in soil. The low utilization is caused by the strong adsorption of $\mathrm{Zn}$ in the soil and not by the reluctance of the plants to take up $\mathrm{Zn}$. This conclusion can be drawn on the basis of the results of pot experiments where high $\mathrm{Zn}$ concentration in the grass occurred when $\mathrm{Zn}$ was added to an unhumified Sphagnum peat and to strongly acid coarse mineral soils of obviously low $\mathrm{Zn}$ adsorption capacities.

The large variations of dry matter yield of timothy and barley in the field and ryegrass in the pot experiment were not reflected as a negative correlation between the size of the yield and the $\mathrm{Zn}$ concentration. This suggests that $\mathrm{Zn}$ uptake by the plants is probably not limited by the capacity factor 
(quantity of plant-available $\mathrm{Zn}$ in soil) but rather by intensity ( $\mathrm{Zn}$ concentration in soil solution). The adsorbed $\mathrm{Zn}$ fraction is much larger than the dissolved one, resulting in a strong buffering of soil $\mathrm{Zn}$ concentration (ElgawHARY et al. 1970). As Zn is taken up by plant roots from the soil solution, the decrease of concentration is readily replenished from the adsorbed fraction, provided the soil is not poor in $\mathrm{Zn}$. It can therefore be concluded that plant uptake does not markedly reduce the $\mathrm{Zn}$ concentration of soil solution. Consequently, the $\mathrm{Zn}$ concentration of plant tissue grown in a given soil can be the same regardless of the size of the yield.

The average $\mathrm{Zn}$ concentration of cereal crops grown in Finland is at the same level as in other countries of temperate climates. In Norway, in Prince Edward Island, Canada and in southwestern Sweden, mean $\mathrm{Zn}$ concentrations of barley and oats have ranged between 28 and $48 \mathrm{mg} \mathrm{Zn} \mathrm{kg}^{-1}$ (FrøSLIE et al. 1983, WINTER and GUPTA 1987, ERIKSSON et al. 1990). Also timothy grown in Finland has on average at least the same $\mathrm{Zn}$ concentration as has been reported elsewhere (METSON et al. 1979, WINTER and GUPTA 1983, BoILA et al. 1985). Owing to the great variation in $\mathrm{Zn}$ concentrations of timothy and barley (JAAKKOLA and VOGT 1978, KÄHÄRI and NISSINEN 1978), it is likely that in areas of poor soil $\mathrm{Zn}$, locally produced fodder may contain much less $\mathrm{Zn}$ than is the national average.

The level of dietary $\mathrm{Zn}\left(50 \mathrm{mg} \mathrm{kg}^{-1}\right)$ recommended for cattle in the Nordic countries (NJF 1975, SALO et al. 1990) appears to be high as compared to recommendations given elsewhere. In the USA, a concentration of $40 \mathrm{mg} \mathrm{kg}^{-1}$ is recommended for dairy cattle (NRC 1978) and $20-30 \mathrm{mg}$ $\mathrm{kg}^{-1}$ for beef cattle (NRC 1976). In New Zealand, a recommendation of $15-25 \mathrm{mg} \mathrm{kg}^{-1}$ for grazing livestock is given (TOWERS and GRACE 1983). In a compilation prepared in England (ARC 1980) 30 $\mathrm{mg} \mathrm{kg}^{-1}$ was regarded as the sufficient level in experimental conditions, but it was also pointed out that in studies made in the field higher concentrations have occasionally been of advantage. The average $\mathrm{Zn}$ concentration of timothy and barley occurring in Finland would thus be considered sufficient for cattle in most countries, and the evidence of a general need of a higher $\mathrm{Zn}$ level in fodder is not conclusive. Zinc concentration of timothy and barley at least in mineral soils does not reach the level recommended in Finland $\left(50 \mathrm{mg} \mathrm{kg}^{-1}\right)$ without excessive $\mathrm{Zn}$ fertilization. Because high $\mathrm{Zn}$ rates result in an undue accumulation of $\mathrm{Zn}$ in the soil, it seems needless to aim at $\mathrm{Zn}$ concentrations beyond the current average level in the crop by increased $\mathrm{Zn}$ fertilization. The recommended $\mathrm{Zn}$ level in the diet should still be reached by direct supplementation into the fodder.

Besides soil $\mathrm{Zn}$ status, $\mathrm{pH}$ and $\mathrm{Zn}$ fertilization, also other factors affect the actual $\mathrm{Zn}$ concentration in fodder of domestic animals. Clover and other dicotyledons have a higher $\mathrm{Zn}$ concentration than gramineous fodder crops (REAY and MARSH 1976, YLÄRANTA and SILLANPÄÄ 1984, McLAREN et al. 1991). Nitrogen fertilization has also been shown to elevate plant $\mathrm{Zn}$ concentration, probably owing to the decrease of $\mathrm{pH}$ (BOAWN et al. 1960, TERMAN et al. 1966). For example, in field experiments by RINNE at al. (1974) and SILLANPÄÄ and RINNE (1975) $\mathrm{Zn}$ concentration in the grass increased from $30 \mathrm{mg} \mathrm{kg}^{-1}$ to $39 \mathrm{mg} \mathrm{kg}^{-1}$ when the $\mathrm{N}$ fertilization was increased from nil to $600 \mathrm{~kg} \mathrm{ha}^{-1}$. On the other hand, the experiments of ETTALA and Kossila $(1979,1980)$ showed that on average $34 \%$ of $\mathrm{Zn}$ in silage grass was lost during the ensiling. These examples propose that the choice of crop as well as different agricultural practices other than $\mathrm{Zn}$ fertilization can affect the $\mathrm{Zn}$ content of the fodder at least as much as was commonly observed to be the effect of $\mathrm{Zn}$ application in the current field experiments with timothy.

Also excessive $\mathrm{Zn}$ concentration in plants need to be considered. The highest concentration in ryegrass grown without added $\mathrm{Zn}$, occurring in the soil of Harjavalta, exceeded $100 \mathrm{mg} \mathrm{kg}^{-1}$ and was of the same magnitude as was reported in grass grown in a $\mathrm{Zn}$-contaminated harbor dredge in the Netherlands (SMILDE et al. 1982). High concentrations of $\mathrm{Zn}$ can thus occur locally in the neighborhood of industry also in Finland. The high concentration of the grass grown in the soil of Harjavalta also shows that $\mathrm{Zn}$ accumulated in the soil probably as a result of atmospheric deposition was plant-available. This conclusion is corroborated by findings showing that the bulk of $\mathrm{Zn}$ in the deposition both in urban 
(GATZ and CHU 1984) and rural (LINDBERG and HARRISS 1981) environments is water-soluble. Various plants may exhibit symptoms of $\mathrm{Zn}$ toxicity when the $\mathrm{Zn}$ concentration of the plant exceeds 120 - $220 \mathrm{mg} \mathrm{kg}^{-1}$ (BECKETT and DAVIS 1977, SAUERBECK 1982) but according to the present study, as much as $500-700 \mathrm{mg} \mathrm{Zn} \mathrm{kg}^{-1}$ was tolerated by ryegrass with only slight adverse effects. This result agrees with those by GERZABECK and SCHAFFER (1989) according to whom the toxicity limit in ryegrass was higher than $400 \mathrm{mg}$ $\mathrm{kg}^{-1}$. Tolerance to large doses of $\mathrm{Zn}$ by domestic animals appears to be even greater (MILLER et al. 1965, Отт et al. 1966). According to Отт et al. (1966), toxicity symptoms occurred only when the dietary $\mathrm{Zn}$ concentration exceeded $900 \mathrm{mg} \mathrm{kg}^{-1}$.
The highest $\mathrm{Zn}$ fertilization rate currently recommended in Finland is $20 \mathrm{~kg} \mathrm{ha}^{-1}$ (Viljavuuspalvelu 1992), corresponding to $10 \mathrm{mg} \mathrm{dm}^{-3}$ in a 20 -cm thick plough layer. The present pot experiments and field experiments by URVAS (1992) showed that at least in strongly acid coarse mineral soils and peat soils $\mathrm{Zn}$ concentration of grass can be elevated beyond the recommended level $\left(50 \mathrm{mg} \mathrm{kg}^{-1}\right)$ by application of maximum recommended $\mathrm{Zn}$ doses. However, in unpolluted cultivated soils $\mathrm{Zn}$ concentration of grass fertilized at that $\mathrm{Zn}$ rate is likely to remain below $100 \mathrm{mg}$ $\mathrm{kg}^{-1}$. It seems thus evident that a $\mathrm{Zn}$ concentration toxic to plants or animals cannot be reached when field crops are fertilized with the recommended rates of $\mathrm{Zn}$.

\section{REFERENCES}

AASEN, I. 1981. Mikronæringsstoff i planter i relasjon til gødsling och forkvalitet. Agric. Univ. Norway B 9/81: 1-13.

Al-Hiyaly, S. A. K., McNeilly, T., Bradshaw, A. D. 1990. The effect of zinc contamination from electricity pylons. Contrasting patterns of evolution in five grass species. New Phytol. 114: 183-190.

Allen, S. E. \& Terman, G. L. 1967. Response of maize and sudangrass to zinc in granular macronutrients. Soil Chemistry and Fertility. Proc. Meeting Comm. II \& IV Internat. Soc. Soil Sci. Aberdeen, Scotland 1966. p. 255266.

ANDERSSON, A. 1979. On the distribution of heavy metals as compared to some other elements between grain size fractions in soils. Swed. J. Agric. Res. 9: 7-13.

— \& Nilsson, K. O. 1976. Influence on the levels of heavy metals in soil and plant from sewage sludge used as fertilizer. Swed. J. Agric. Res. 6: 151-159.

ARC 1980. The nutrient requirements of ruminant livestock. Agricultural Research Council. Commonwealth Agricultural Bureaux, Slough, England. 351 p.

Armour, J. D., Rrtchie, G. S. P. \& Robson, A. D. 1990. Extractable zinc in particle size fractions of soils from Westem Australia and Queensland. Austr. J. Soil Res. 28: 387-397.

Asher, L. E. \& BAR-Yosef, B. 1982. Effects of pyrophosphate, EDTA, and DTPA on zinc sorption by montmorillonite. Soil Sci. Soc. Amer. J. 46: 271-276.

AunelA, L. \& LARJAVA, K. 1990. Raskasmetallipäästöt Suomessa. Abstract: Heavy metal emissions in Finland.
Techn. Res. Centr. Finl. Res. Notes 1181: 1-70.

Baghdady, N. H. \& Sippola, J. 1983. Total heavy metal recovery by aqua regia in soils of different origin. Ann. Agric. Fenn. 22: 175-185.

BaKhsh, A., Flowers, Th. \& Pulford, I. D. 1990. Effect of growing ryegrass on the distribution of zinc in soil pools. Plant and Soil 129: 187-194.

BANDA, D. J. \& SINGH, B. R. 1989. Establishment of critical levels of zinc for maize in soils of the high rainfall areas of Zambia. Norwegian J. Agric. Sci. 3: 221-227.

BAR-Yosef, B. \& AsHer, L. E. 1983. Reactions of pyrophosphate in soils and its effect on zinc sorption at various $\mathrm{pH}$ levels. Soil Sci. 136: 82-88.

B Asсомв, C. L. 1968. Distribution of pyrophosphate-extractable iron and organic carbon in soils of various groups. J. Soil Sci. 19: 251-268.

BECKETT, P. H. T. \& DAvis, R. D. 1977. Upper critical levels of toxic elements in plants. New Phytol. 79: 95-106.

Bergholm, J. \& SteEn, E. 1989. Vegetation establishment on a deposit of zinc mine wastes. Environ. Poll. 56: 127-144.

Berndt, G. F. \& Kershaw, C. D. 1989. A survey of the zinc content of arable soils in the south-east of Scotland. Res. Devel. Agric. 6: 87-90.

Bishop, R. F. \& MACEACHERn, C. R. 1973. The zinc status of some Nova Scotia soils and crops. Commun. Soil Sci. Plant Anal. 4: 41-50.

BJERRE, G. K. \& ShiERUP, H. 1985. Uptake of six heavy metals by oat as influenced by soil type and additions of cadmium, lead, zinc and copper. Plant and Soil 88: 57-69.

Boawn, L. C. 1973. Comparison of zinc sulfate and zinc 
EDTA as zinc fertilizer sources. Soil Sci. Soc. Amer. Proc. 37: 111-115.

—, Viets, F. G. Jr., Crawford, C. L. \& Nelson, J. L. 1960. Effect of nitrogen carrier, nitrogen rate, and soil $\mathrm{pH}$ on zinc uptake by sorghum, potatoes and sugar beets. Soil Sci. 90: 329-337.

Bolla, R. J., Devlin, T. J., Drysdale, R. A. \& Lillie, L. E. 1985. Geographical variability of the zinc concentrations of forages grown in northwestern Manitoba. Can. J. Anim. Sci. 65: 861-879.

BorgGaARD, O. K. 1979. Selective extraction of amorphous iron oxides by EDTA from a Danish sandy loam. J. Soil Sci. 30: 727-734.

- 1988. Phase identification by selevctive dissolution techniques. In: Stucki, J. W. et al. (eds.). Iron in soils and clay minerals. NATO ASI Series C 217: 83-89.

- 1992. Dissolution of poorly crystalline iron oxide in soils by EDTA and oxalate. Z. Pfl.ernähr. Bodenk. 155: 431436.

Boswell, F. C., Parker, M. B. \& Gaines, T. P. 1989. Soil zinc and $\mathrm{pH}$ effects on zinc concentrations of corn plants. Commun. Soil Sci. Plant Anal. 20: 1575-1600.

Bremner, J. M. \& Lees, H. 1949. Studies on soil organic matter. Part II. The extraction of organic matter from soil by neutral reagents. J. Agric. Sci. 39: 274-279.

Brennan, R. F. \& Gartrel., J. W. 1990. Reaction of zinc with soil affecting its availability to subterranean clover. I. The relationship between critical concentrations of extractable zinc and properties of Australian soils responsive to applied zinc. Austr. J. Soil Res. 28: 293-302.

Brown, A. L. \& KRANTZ, B. A. 1966. Source and placement of zinc and phosphorus for corn (Zea mays L.). Soil Sci. Soc. Amer. Proc. 30: 86-89.

Brómer, G. W., Tlller, K. G., Herms, U. \& Clayton, P. M. 1983. Adsorption-desorption and/or precipitation-dissolution processes of zinc in soils. Geoderma 31: 337-354.

CARSKY, R. J. \& REID, W. S. 1990. Response of corn to zinc fertilization. J. Production Agric. 3: 502-507.

CAss, G. R. \& McRAE, G. J. 1983. Source-receptor reconciliation of routine air monitoring data for trace metals: An emission inventory assisted approach. Environ. Sci. Technol. 17: 129-139.

Christie, P. \& Beattie, J. A. M. 1989. Grassland soil microbial biomass and accumulation of potentially toxic metals from long-term slurry application. J. Appl. Ecol. 26: 597-612.

DAvies, B. E. 1985. The plant-availability of $\mathrm{Cd}, \mathrm{Pb}$ and $\mathrm{Zn}$ in soils with reference to soil extracts, $\mathrm{pH}$ and redox potential. J. Sci. Food Agric. 36: 535-536.

Delaune, R. D., Gambrell, R. P. \& Knox, R. S. 1989. Accumulation of heavy metals and PCB's in an urban lake. Environ. Technol. Lett. 10: 753-762.

DrIEL, W. van \& SMILDE, K. W. 1990. Micronutrients and heavy metals in Dutch agriculture. Fert. Res. 25: 115126.

Dwyer, L. M., Stewart, D. W. \& Balchin, D. 1988. Rooting characteristics of corn, soybeans and barley as a function of available water and soil physical characteristics. Can. J. Soil Sci. 68: 121-132.
Elgawhary, S. M., Lindsay, W. L. \& Kempre, W. D. 1970. Effect of EDTA on the self-diffusion of zinc in aqueous solution and in soil. Soil Sci. Soc. Amer. Proc. 34: 66-70.

El-Kherbawy, M. I. \& S Anders, R. 1984. Effects of pH and phosphate status of a silty clay loam on manganese, zinc and copper concentrations in soil fractions and in clover. J. Sci. Food Agric. 35: 733-739.

Eluis, B. G., Davis, J. F. \& JudY, W. H. 1965. Effect of method of incorporation of zinc in fertilizer on zinc uptake and yield of pea beans (Phaseolus vulgaris). Soil Sci. Soc. Amer. Proc. 29: 635-636.

Elonen, P. 1971. Particle-size analysis of soil. Acta Agr. Fenn. 122: 1-122.

ELSOKKARY, I. H. 1979. The chemical fractionation of soil zinc and its specific and total adsorption by Egyptian alluvial soils. Plant and Soil 53: 117-129.

— \& LẢG, J. 1978. Distribution of different fractions of Cd, $\mathrm{Pb}, \mathrm{Zn}$ and $\mathrm{Cu}$ in industrially polluted and non-polluted soils of Odda region, Norway. Acta Agric. Scand. 28: 262-268.

Eriksson, J. E. , Andersson, A. \& Wenblad, A. 1990. Cd, Ni and $\mathrm{Zn}$ contents of oat grain as related to soil factors and precipitation. Swed. J. Agric. Res. 20: 81-87.

ERviö, R., MÄKEL_Ä-KuRTto, R. \& SipPOLA, J. 1990. Chemical characteristics of Finnish agricultural soils in 1974 and in 1987. In: Kauppi, P. et al. (eds.). Acidification in Finland. p. 217-234. Berlin.

— \& VIRRI, K. 1965. Hivenaineista eteläisen Keski-Uudenmaan maaperässä. Summary: Trace element contents in the soils of Middle Uusimaa. Ann. Agric. Fenn. 4: 178184.

Ettal.A, E. \& Kossil.A, V. 1979. Mineral content in heavily nitrogen fertilized grass and its silage. Ann. Agric. Fenn. 18: 252-262.

— \& KossiLA, V. 1980. Organic matter, mineral and nitrogen losses from fresh grass silage during ensiling. Ann. Agric. Fenn. 19: 9-20.

Folkeson, L. \& ANDERSSON-BringmaRK, E. 1988. Impoverishment of vegetation in a coniferous forest polluted by copper and zinc. Can. J. Bot. 66: 417-428.

Frøslie, A., Norheim, G. \& Sols, N. E. 1983. Levels of copper, molybdenum, zinc and sulphur in concentrates and mineral feeding stuffs in relation to chronic copper poisoning in sheep in Norway. Acta Agric. Scand. 73: 261-267.

GATZ, D. \& ChU, L. C. 1984. Metal solubility in atmospheric deposition. Adv. Environ. Sci. Technol. 17: 391-408.

GerZABEK, M. H. \& SchafFer, K. 1989. Nickel- und Zincaufnahme durch Lolium perenne L. im Gefässversuch. Bodenkultur 40: 195-205.

GoldschmidT, V. M. 1937. The principles of distribution of chemical elements in minerals and rocks. J. Chem. Soc. 1: 655-673.

Graham, E. R. 1948. Determination of soil organic matter by means of a photoelectric colorimeter. Soil Sci. 65: 181183.

GuptA, U. C. 1989. Effect of zinc fertilization on plant zinc concentration of forages and cereals. Can. J. Soil Sci. 69: 473-479. 
HÄNI, H. \& GuPTA, S. 1985. Reasons to use neutral salt solutions to assess the metal impact on plant and soils. In: Leschber, R. et al. (eds.). Chemical methods for assessing bioavailable metals in sludges and soils. p. 42-48.

Haq, A. U. \& Miller, M. H. 1972. Prediction of available soil $\mathrm{Zn}, \mathrm{Cu}$, and $\mathrm{Mn}$ using chemical extractants. Agron. J. $64: 779-782$.

Haynes, R. J. \& Swift, R. S. 1985. Effects of soil acidification on the chemical extractability of $\mathrm{Fe}, \mathrm{Mn}, \mathrm{Zn}$ and $\mathrm{Cu}$ and the growth and micronutrient uptake of highbush blueberry plants. Plant and Soil 84: 201-212.

Hergert, G. W., Rehm, G. W. \& Wiese, R. A. 1984. Field evaluation of zinc sources band applied in ammonium polyphosphate suspensions. Soil Sci. Soc. Amer. J. 48: 1190-1193.

HibBard, P. L. 1940. Accumulation of zinc on soil under long persistent vegetation. Soil Sci. 50: 53-55.

Hornburg, V. \& Brómmer, G. W. 1991. Schwermetall-Verfügbarkeit und Transfer in Abhängigkeit von $\mathrm{pH}$ und Stoffbestand der Böden. Mitt. Deut. Bodenk. Ges. 66: 661-664.

Houba, V. J. G., Novozamsky, I., Lexmond, Th. M. \& Lee, J. J. van der. 1990. Applicability of $0.01 \mathrm{M} \mathrm{CaCl}_{2}$ as a single extraction solution for the assessment of the nutrient status of soils and other diagnostic purposes. Commun. Soil Sci. Plant Anal. 21: 2281-2290.

Huang, P. M. 1989. Feldspars, olivines, pyroxenes, and amphiboles. In: Dixon, J. B. \& Weed, S. B. (eds.). Minerals in soil environments. Madison, Wisconsin, USA. p. 9751050.

Iyengar, S. S., Martens, D. C. \& Miller, W. P. 1981. Distribution and plant-availability of soil zinc fractions. Soil Sci. Soc. Amer. J. 45: 735-739.

JaAkKola, A. \& Vogt, P. 1978. The effect of mineral elements added to Finnish soils on the mineral contents of cereal, potato and hay crops. I. Calcium, magnesium, phosphorus, potassium, copper, iron, manganese, sodium and zinc. Acta Agric. Scand. Suppl. 20: 53-68.

Jahiruddin, M., Chambers, B. J., Livesey, N. T. \& Cresser, M. S. 1986. Effect of liming on extractable $\mathrm{Zn}, \mathrm{Cu}, \mathrm{Fe}$, and $\mathrm{Mn}$ in selected Scottish soils. J. Soil Sci. 37: 603-615.

JeFFery, J. J. \& UREN, N. C. 1983. Copper and zinc species in the solution and the effects of soil pH. Austr. J. Soil Res. 21: 479-488.

Jordao, C. P. \& Nickless, G. 1989. Chemical associations of $\mathrm{Zn}, \mathrm{Cd}, \mathrm{Pb}$ and $\mathrm{Cu}$ in soils and sediments determined by the sequential extraction technique. Environ. Technol. Lett. 10: 743-752.

Junus, M. A. \& Cox, F. R. 1987. A zinc soil test calibration based upon Mehlich 3 extractable zinc, $\mathrm{pH}$, and cation exchange capacity. Soil Sci. Soc. Amer. J. 51: 678-683.

JUUSELA, T. \& WÄRE, M. 1956. Suomen peltojen kuivatustila. Draining condition of the cultivated fields in Finland. Soil Hydrotechn. Res. 8: 1-89. Helsinki.

Kabata-Pendias, A. \& Pendias, H. 1984. Trace elements in soils and plants. 315 p. Boca Raton, Florida, USA.

KÄHÄRI, J. \& NisSINEN, H. 1978. The mineral element contents of timothy (Phleum pratense L.) in Finland. I. The elements calcium, magnesium, phosphorus, potassium, chromium, cobalt, copper, iron, manganese, sodium and zinc. Acta Agric. Scand. Suppl. 20: 26-39.

Kemira 1992. Lannoitteiden myynnin jakautuminen maaseutukeskusalueittain lannoitusvuonna 1991/1992. Kemira Agro. 12 p. Helsinki. [Fertilizer sales by rural advisory district, fertilizer year 1991/1992.]

Kemppainen, E. 1989. Nutrient content and fertilizer value of livestock manure with special reference to cow manure. Ann. Agric. Fenn. 28: 163-284.

Kivioja, M. 1987. Lannoitteiden kemiaa. Kemira Oy. Espoon tutkimuskeskus. 61 p. 2nd Ed. [Chemistry of fertilizers. Kemira Oy Espoo Res. Centr.]

KolJonen, T. \& Malisa, E. 1991. Solubility in aqua regia of selected chemical elements occurring in the fine fraction of till. Environmental geochemistry in northern Europe. Geol. Surv. Finl. Spec. Pap. 9: 49-52.

Kowalenko, C. G., Maas, E. F. \& Vanlaerhoven, C. I. 1980. Residual effects of limestone, $\mathrm{P}, \mathrm{K}$ and $\mathrm{Mg}$ applications: evidence of induced $\mathrm{Mn}$ and $\mathrm{Zn}$ deficiency in oats. Can. J. Soil Sci. 60: 757-761.

KURKI, M. 1982. Suomen peltojen viljavuudesta III. Summary: On the fertility of Finnish tilled fields in the light of investigations of soil fertility carried out in the years 1955 - 1980. 181 p. Helsinki.

LÅg, J. \& ElsoKKaRY, I. H. 1978. A comparison of chemical methods for estimating $\mathrm{Cd}, \mathrm{Pb}$, and $\mathrm{Zn}$ availability to six food crops grown in industrial polluted soils at Odda, Norway. Acta Agric. Scand. 28: 76-80.

LAKANEN, E. 1969. Mineral composition of Finnish timothy. Ann. Agric. Fenn. 8: 20-29.

— \& ERviö, R. 1971. A comparison of eight extractants for the determination of plant available micronutrients in soils. Acta Agr. Fenn. 123: 223-232.

LARGE, E. C. 1954. Growth stages in cereals. Illustration of the Feekes scale. Plant Path. 3: 128-129.

Levesque, M. P. \& Mathur, S. P. 1986. Soil tests for copper, iron, manganese, and zinc in Histosols: 1 . The influence of soil properties, iron, manganese, and zinc on the level and distribution of copper. Soil Sci. 142: 153-163.

LEYDEN, R. F. \& Toth, S. J. 1960. Behavior of zinc sulfate as foliar applications and as soil applications in some New Jersey soils. Soil Sci. 89: 223-228.

Liang, J., Karamanos, R. E. \& Stewart, J. W. B. 1990. Distribution of zinc fractions in prairie soils. Can. J. Soil Sci. 70: 335-342.

Lichtruss, R. \& AndResen, H. U. 1983. Spurenelementverteilung in jungpleistozänen Bodentoposequenzen Ostholsteins. Mitt. Deut. Bodenk. Ges. 38: 227-232.

LiM, C. H. \& JACKson, M. L. 1982. Dissolution for total elemental analysis. In: Page, A.R. et al. (eds.). Methods of soil analysis. Part 2. Agron. Monograph 9: 1-12.

LindBerg, S. E. \& HARRISS, R. C. 1981. The role of atmospheric deposition in an eastern U.S. deciduous forest. Water Air Soil Poll. 16: 13-31.

LindsAY, W. L. 1972. Zinc in soils and plant nutrition. Adv. Agron. 24: 147-186.

— \& Norvell, W. A. 1978. Development of a DTPA soil test for zinc, iron, manganese and copper. Soil Sci. Soc. Amer. J. 42: 421-428. 
Linehan, D. J., Sinclair, A. H. \& Mitchell, M. C. 1985. Mobilisation of $\mathrm{Cu}, \mathrm{Mn}$ and $\mathrm{Zn}$ in the soil solutions of barley rhizospheres. Plant and Soil 86: 147-149.

Lins, I. D. G. \& Cox, F. R. 1988. Effect of soil pH and clay content on the zinc soil test interpretation for corn. Soil Sci. Soc. Amer. J. 52: 1681-1685.

McBride, M. B. 1989. Reactions controlling heavy metal solubility in soils. Adv. Soil Sci. 10: 1-56.

— \& BlasiaK, J. J. 1979. Zinc and copper solubility as a function of $\mathrm{pH}$ in an acid soil. Soil Sci. Soc. Amer. J. 43: 866-870.

McLaren, R. G. \& Crawford, D. V. 1973. Studies on soil copper. I. The fractionation of copper in soils. J. Soil Sci. 24: 172-181.

—, Mclenaghen, R. D. \& Swift, R. S. 1991. Zinc applications to pastures: effect on herbage and soil zinc concentrations. N. Z. J. Agric. Res. 34: 113-118.

MacNaeidhe, F. S., Fleming, G. A. \& Parle, P. J. 1986. Zinc deficiency - first time in cereals in Ireland. Farm Food Res. 17: 57-58.

MARSCHNER, H. 1986. Mineral nutrition of higher plants. 674 p. Belfast, Northern Ireland.

MARTENS, D. C. 1968. Plant availability of extractable boron, copper and zinc as related to selected soil properties. Soil Sci. 106: 23-28,

Менцісн, A. 1984. Mehlich 3 soil test extractant: A modification of Mehlich 2 extractant. Commun. Soil Sci. Plant Anal. 15: 1409-1416.

Merckx, R., Ginkel, J. H. van, Sinnaeve, J. \& Cremes, A. 1986. Plant-induced changes in the rhizosphere of maize and wheat. Plant and Soil 96: 95-107.

Merkel, D. \& Köter, W. 1977. Der Nachweis einer Zinctoxicität bei Kulturpflanzen durch die Bodenuntersuchung mit Hilfe der $\mathrm{CaCl}_{2}$-Methode. Landw. Forsch. Sonderheft 33/I: 274-281.

Metson, A. J., Gibbson, E. J., Hunt, J. L. \& Saunders, W. M. H. 1979. Seasonal variations in chemical composition of pasture. N. Z. J. Agric. Res. 22: 309-318.

Miller, W. J., Clifton, C. M. \& Fowler, P. R. 1965. Influence of high levels of dietary zinc on zinc in milk, performance and biochemistry of lactating cows. J. Dairy Sci. 48: 450-453.

Miller, W. P. \& McFee, W. W. 1983. Distribution of cadmium, zinc, copper, and lead in soils of industrial northwestern Indiana. J. Environ. Qual. 12: 29-33.

MortvedT, J. J. 1968. Crop response to applied zinc in ammoniated phosphate fertilizers. J. Agric. Food Chem. 16: 241-245.

— \& Giordano, P. M. 1969a. Availability to corn of zinc applied with various macronutrient fertilizers. Soil Sci. 108: 180-187.

— \& Giordano, P. M. 1969b. Extractability of zinc granulated with macronutrient fertilizers in relation to its agronomic effectiveness. J. Agric. Food Chem. 17: 12721275.

— \& OsBorn, G. 1977. Micronutrient concentrations in soil solution after ammonium phosphate applications. Soil Sci. Soc. Amer. J. 41: 1004-1009.

MsaKy, J. J. \& CAlvet, R. 1990. Adsorption behavior of copper and zinc in soils: influence of $\mathrm{pH}$ on adsorption characteristics. Soil Sci. 150: 513-522.

Mullins, G. L., Martens, D., Gettier, S. W. \& Miller, W. P. 1982. Forms and availability of copper and zinc in a Rhodic Paleudult following long-term $\mathrm{CuSO}_{4}$ and $\mathrm{ZnSO}_{4}$ applications. J. Environ. Qual. 11: 573-577.

MYHR, K. 1988. Gjødsling med sink og mangan till bygg på alkalisk jord. Abstract: Zinc and manganese fertilization of barley on alkaline soil. Norsk Landbr.forskn. 2: 103109.

MyllymaA, U. \& Murtoniemi, S. 1986. Metals and nutrients in the sediments of small lakes in Kuusamo, North-eastern Finland. National Board of Waters and Environment. Publ. Water Res. Inst. 69: 33-48.

Nielsen, D., Hoyt, P. B. \& MacKenzIE, A. F. 1986. Distribution of soil $\mathrm{Zn}$ fractions in British Columbia interior orchard soils. Can. J. Soil Sci. 66: 445-454.

—, Hoyt, P. B. \& MacKenzie, A. F. 1987. Measurement of plant-available zinc in British Columbia orchard soils. Commun. Soil Sci. Plant Anal. 18: 161-186.

NiskANEN, R. 1989. Extractable aluminum, iron and manganese in mineral soils. II. Extractability by oxalate and pyrophosphate. J. Agric. Sci. Finl. 61: 79-87.

NJF 1975. Förslag till normer för makro- och mikromineraler till nötkreatur och svin. Nordiska Jordbruksforskares Förening. Foderjournalen 14: 54-106.

NRC 1976. Nutrient requirements of domestic animals. Nutrient requirements of beef cattle. National Research Council. 59 p. 5 th Ed. Washington, D.C., USA.

- 1978. Nutrient requirements of domestic animals. Nutrient requirements of dairy cattle. National Research Council. 76 p. 5th Ed. Washington, D.C., USA.

ÖBLAD, M. \& SElIN, E. 1986. Measurements of elemental composition in background aerosol on the west coast of Sweden. Atmos. Environ. 20: 1419-1432.

Otson, R. V. \& Eluis, R., Jr. 1982. Iron. In: Page, L. et al. (eds.). Methods of soil analysis. Part 2. Agron. Monograph 9: 301-312.

Ott, E. A., Smith, W. H., Harrington, R. B. \& Beeson, W. W. 1966. Zinc toxicity in ruminants. J. Anim. Sci. 25: 414-438.

PALKo, J. 1986. Mineral element content of timothy in acid suplhate soil area of Tupos village, Northern Finland. Acta Agric. Scand. 36: 399-409.

— \& YLI-HALLA, M. 1990. Solubility of Al, Cr, Cu and Zn in soils from a Finnish acid sulphate soil area. Acta Agric. Scand. 40: 117-122.

Paterson, J. E., Berndt, G. F., Cameron, D. \& Rowbottom, W. 1991. Investigation into the response of barley to applied zinc. J. Sci. Food Agric. 54: 387-392.

Payne, G. G., Martens, D. C. Winarko, C. \& Perera, N. F. 1988. Form and availability of copper and zinc following long-term copper sulfate and zinc sulfate applications. J. Environ. Qual. 17: 707-711.

Pessi, Y., Syvälahti, J., SAari, E. \& Ylänen, M. 1974. Mineral content of grain yield of cereals and the effect of fertilization on it. J. Scient. Agric. Soc. Finl. 46: 264-270.

Pulford, I. D. 1986. Mechanisms controlling zinc solubility in soils. J. Soil Sci. 37: 427-438. 
Rankama, K. \& Sahama, Th. G. 1950. Geochemistry. 912 p. Chicago.

Ranta, E., Rita, H. \& Koukı, J. 1991. Biometria. Tilastotiedettä ekologeille. 569 p. 3rd Ed. Helsinki. [Biometry. Statistics for ecologists.]

RÄSÄNEN, M.-L. \& HÄMÄLÄINEN, L. 1991. Selective sequential dissolution of polluted and non-polluted sediments. Environmental geochemistry in northern Europe. Geol. Surv. Finl. Spec. Pap. 9: 157-162.

RASHID, M. A. 1974. Absorption of metals on sedimentary and peat humic acids. Chem. Geol. 13: 115-123.

ReAY, P. F. \& Marsh, B. 1976. Elemental composition of ryegrass and red clover leaves during a growing season. N. Z. J. Agric. Res. 19: 469-472.

Rengell, Z. \& Robinson, D. L. 1989. Aluminium effects on micronutrient uptake by annual ryegrass. Commun. Soil Sci. Plant Anal. 20: 253-269.

Rinne, S.-L., SillanpäĀ, M., Huokuna, E. \& Hitvola, S.-L. 1974. Effects of heavy nitrogen fertilization on iron, manganese, sodium, zinc, copper, strontium, molybdenum and cobalt contents in ley grasses. Ann. Agric. Fenn. 13: 109-118.

Ross, H. B. 1987. Trace metals in precipitation in Sweden. Water Air Soil Poll. 36: 349-363.

Rutledge, E. M., Wilding, L. P. \& Elfield, M. 1967. Automated particle-size separation by sedimentation. Soil Sci. Soc. Amer. Proc. 31: 287-288.

SAlo, M.-L., TuORI, M. \& KIISKInEN, T. 1990. Rehutaulukot ja ruokintanormit. Märehtijät - siat - siipikarja - turkiseläimet. 70 p. 3rd Ed. Helsinki. [Fodder tables and feeding standards. Ruminants - swine - poultry - fur animals.]

SAlomons, W. 1984. Impact of atmospheric inputs on the hydrospheric trace metal cycle. Adv. Environ. Sci. Technol. 17: 409-466.

SAUERBECK, D. 1982. Welche Schwermetallgehalte in Pflanzen dürfen nicht uberschritten werden, um Wachstumsbeeinträchtigungen zu vermeiden? Landw. Forsch. Sonderheft 39: 108-129.

— \& STYPEREK, P. 1985. Evaluation of chemical methods for assessing the $\mathrm{Cd}$ and $\mathrm{Zn}$ availability from different soils and sources. In: Leschber, R. et al. (eds.). Chemical methods for assessing bioavailable metals in sludges and soils. p. 49-67.

SChlichting, E. \& Elgala, A. M. 1975. Schwermetallverteilung und Tongehalte in Böden. Z. Pfl.ernähr. Bodenk. 138: 563-571.

Schnappinger, M. G. Jr., Martens, D. C., Hawkins, G. W., Amos, D. F. \& McCART, G. D. 1972. Response of corn to residual and applied zinc as $\mathrm{ZnSO}_{4}$ and $\mathrm{Zn}$-EDTA in field investigations. Agron. J. 64: 64-66.

Shuman, L. M. 1979. Zn, Mn, and Cu in soil fractions. Soil Sci. 127: 10-17.

- 1985. Fractionation method for soil microelements. Soil Sci. 140: 11-22.

- 1986. Effect of liming on the distribution of manganese, copper, iron, and zinc among soil fractions. Soil Sci. Soc. Amer. J. 50: 1236-1240.

SILLANPÄÄ, M. 1982. Micronutrients and the nutrient status of soils: a global study. FAO Soils Bull. 48: 1-446.

- 1990. Micronutrient assessment at the country level: an international study. FAO Soils Bull. 63: 1-208.

— \& LAKANEN, E. 1966. Readily soluble trace elements in Finnish soils. Ann. Agric. Fenn. 5: 298-304.

— \& RinNe, S.-L. 1975. The effect of heavy nitrogen fertilization on the uptake of nutrients and on some properties of soil cropped with grasses. Ann. Agric. Fenn. 14: 210226.

Sims, J. T. 1986. Soil pH effects on the distribution and plant availability of $\mathrm{Mn}, \mathrm{Cu}$, and $\mathrm{Zn}$. Soil Sci. Soc. Amer. J. 50: 367-373.

— \& PATRICK, W. H. Jr. 1978. The distribution of micronutrient cations in soil under conditions of varying redox potential and $\mathrm{pH}$. Soil Sci. Soc. Amer. J. 42: 258-262.

Singh, J. P., Karwasra, S. P. S. \& Singh, M. 1988. Distribution and forms of copper, iron, manganese, and zinc in calcareous soils of India. Soil Sci. 146: 359-366.

SIPPOLA, J. 1974. Mineral composition and its relation to texture and some chemical properties in Finnish subsoils. Ann. Agric. Fenn. 13: 169-234.

— \& TARES, T. 1978. The soluble content of mineral elements in cultivated Finnish soils. Acta Agric. Scand. Suppl. 20: 11-25.

SMILDE, K. W., Driel, W. van, \& LuIt, B. van. 1982. Constraints in cropping heavy-metal contaminated fluvial sediments. Sci. Total Environ. 25: 225-244.

Sommer, A. L. \& Lipman, C. B. 1926. Evidence on the indispensable nature of zinc and boron for higher plants. Plant Physiol. 1: 231-249.

Steel, R. G. D. \& Torrie, J. H. 1981. Principles and procedures of statistics. A biometrical approach. 633 p. 2nd Ed. Singapore.

Steinness, E., Solberg, W., Petersen, H. M. \& Wren, C. D. 1989. Heavy metal pollution by long range atmospheric transport in natural soils of southern Norway. Water Air Soil Poll. 45: 207-218.

Stevenson, F. J. 1982. Humus chemistry. 443 p. New York.

Stewart, J. A. \& Berger, K. C. 1965. Estimation of available soil zinc using magnesium chloride as extractant. Soil Sci. 100: 244-249.

Syvälahti, J. \& Korkman, J. 1978. The effect of applied mineral elements on the mineral content and yield of cereals and potato in Finland. Acta Agric. Scand. Suppl. 20: $80-89$.

TAмm, O. 1922. A method for the determination of the inorganic components of colloids in soils. Medd. Skogsforskanst. 19: 385-404.

Teicher, K., Fischer, P., Bartels, W. \& Gunther, J. 1987. Haupt- und Spurennährstoffe in Hochmoortorfen und die physikalishen Eigenshaften dieser Torfe. Telma 17: 199211.

Terman, G. L., Allen, S. E. \& Bradford, B. N. 1966. Response of corn to zinc as affected by nitrogen and phosphorus fertilizers. Soil Sci. Soc. Amer. Proc. 30: 119-124.

Tilastokeskus 1992. Teollisuuden vuosikirja. Yearbook of industrial statistics 2.378 p. Helsinki.

Tiller, K. G., Gerth, J. \& Brommer, G. 1984. The sorption 
of $\mathrm{Cd}, \mathrm{Zn}$ and $\mathrm{Ni}$ by soil clay fractions: procedures for partition of bound forms and their interpretation. Geoderma 34: 1-16.

Tuel., J. C. \& Hovmand, M. F. 1978. Metal concentrations in Danish arable soils. Acta Agric. Scand. 28: 81-89.

Torres-Martin, M. \& Gallardo-Lara, F. 1991. Dynamics of zinc fractions in the soil plant system under conditions of intensive forage cropping. Commun. Soil Sci. Plant Anal. 22: 2089-2100.

Towers, N. R. \& Grace, N. D. 1983. Zinc. In: Grace, N. D. (ed.). The mineral requirements of grazing animals. p. 84-91.

URVAS, L. 1985. Koetuloksia turvemaan sinkkilannoituksesta. Abstract: Results about zinc fertilization in peat soil. Suovilj.yhd. Vuosik. 86-90: 47-57.

- 1986. Timotein (Phleum pratense) sinkkipitoisuus turvemaalla. Abstract: The zinc content of timothy (Phleum pratense) grown on peat soil. Suo 37: 7-10.

- 1990. Sinkkisulfaatti timotein lannoitteena. Maatalouden tutkimuskeskus, Tiedote 8/90: 1-11. [Zinc sulphate as a fertilizer for timothy.]

- 1992. Kalium-, mangaani- ja sinkkilannoituksen vaikutus timoteinurmen ravinnepitoisuuteen Pohjois-Suomen suonurmilla. Maatalouden tutkimuskeskus, Tiedote 3/92: 1-23. [Effect of potassium, manganese and zinc fertilization on the nutrient content of timothy in peatland swards of northern Finland.]

— , JokInen, R. \& HYvÄrInEN, S. 1992. Uuttuva sinkki viljellyissä eloperäisissä maissa. Abstract: Extractability of zinc in cultivated organic soils. Suo 43: 37-44.

— \& Sornı, S. 1984. The effect of intensive grassland cultivation on the plant nutrient balance in peat soil. Proc. 7 th Intern. Peat Congr. Dublin. 4: 71-85.

Varo, P., NuUrtamo, M., SaAri, E. \& Koivistoinen, P. 1980.
Mineral element composition of Finnish foods: N, K, Ca, $\mathrm{Mg}, \mathrm{P}, \mathrm{S}, \mathrm{Fe}, \mathrm{Cu}, \mathrm{Mn}, \mathrm{Zn}, \mathrm{Mo}, \mathrm{Co}, \mathrm{Ni}, \mathrm{Cr}, \mathrm{F}, \mathrm{Se}, \mathrm{Si}, \mathrm{Rb}$, $\mathrm{Al}, \mathrm{B}, \mathrm{Br}, \mathrm{Hg}, \mathrm{As}, \mathrm{Cd}, \mathrm{Pb}$ and ash. III. Annual variations in the mineral element composition of cereal grains. Acta Agric. Scand. Suppl. 22: 27-36.

Verta, M., Tolonen, K. \& Simola, H. 1989. History of heavy metal pollution in Finland as recorded by lake sediments. Sci. Total Environ. 87-88: 1-18.

VIETS, F. G., Jr. 1962. Chemistry and availability of micronutrients in soils. J. Agric. Food Chem. 10: 174-178.

Viljavuuspalvelu 1992. Viljavuustutkimuksen tulkinta peltoviljelyssä. Viljavuuspalvelu Oy. 64 p. Helsinki. [Interpretation of the results of soil testing in field crop cultivation. Soil Analysis Service Ltd.]

VUORINEN, M. 1958. On the amounts of mineral elements in Finnish soils. J. Scient. Agric. Soc. Finl. 30: 30-35.

WEAR, J. I. 1956. Effect of soil pH and calcium on uptake of zinc by plants. Soil Sci. 81: 311-315.

WEDEPOHL, K. H. 1991. The composition of the upper earth's crust and natural cycles of selected metals. In: Merian, E. (ed.). Metals and their compounds in the environment. p. 3-17.

WiKLANDER, L. \& VAHTRAs, K. 1977. Solubility and uptake of heavy metals from a Swedish soil. Geoderma 19: 123-129.

WinTER, K. A. \& GUPTA, U. C. 1983. The mineral content of timothy grown in Prince Edward Island. Can. J. Anim. Sci. 63: 133-139.

Woltz, S., Toth, S. J. \& Bear, F. E. 1953. Zinc status of New Jersey soils. Soil Sci. 76: 115-122.

Yläranta, T. \& SillanPÄÄ, M. 1984. Micronutrient contents of different plant species grown side by side. Ann. Agric. Fenn. 23: 158-170. 


\title{
SELOSTUS
}

\section{Viljelymaan sinkkivarojen ja lannoitteena annetun sinkin käyttökelpoisuus kasveille}

\author{
MARKKU YLI-HALLA
}

Helsingin yliopisto

Suomen viljelymaiden $\mathrm{Zn}$-varojen suuruutta, liukoisuutta ja käyttökelpoisuutta kasveille tutkittiin maa-analyysein ja astiakokein. Erilaisten $\mathrm{Zn}$-lannoitteiden vaikutusta raiheinän, timotein ja ohran satoon ja $\mathrm{Zn}$-pitoisuuteen tutkittiin astia- ja kenttäkokein. Sinkin kokonaispitoisuus $\left(\mathrm{Zn}_{\mathrm{tot}}\right) 106$ pintamaanäytteen aineistossa oli $10-202 \mathrm{mg} \mathrm{kg}^{-1}$. Kivennäismaissa $\mathrm{Zn}_{\text {tot }}$ oli positiivisessa korrelaatiossa savespitoisuuden kanssa $\left(r=0,81^{* * *}\right)$ ja eloperäisissä maissa $\mathrm{Zn}_{\text {tot }}$ korreloi negatiivisesti maan orgaanisen hiilen pitoisuuden kanssa $(r=$ $-0,53^{* *}$ ). Useiden savimaiden $\mathrm{Zn}_{\text {tot }}$ oli yli $150 \mathrm{mg} \mathrm{kg}^{-1}$, kun taas muutamien runsaimmin orgaanista hiiltä sisältävien tur-

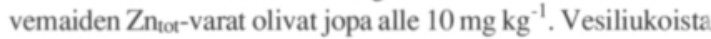
ja vaihtuvaa sinkkiä $\left(\mathrm{Zn}_{\mathrm{ex}}\right)$ uutettiin $0,5 \mathrm{M} \mathrm{MgCl}_{2}$-liuoksella $\mathrm{Zn}_{\mathrm{ex}}$ korreloi negatiivisesti maan $\mathrm{pH}: \mathrm{n}$ kanssa. Pääosin orgaanisen aineksen sitomaksi oletettua sinkkiä uutettiin $0,1 \mathrm{M}$ $\mathrm{K}_{4} \mathrm{P}_{2} \mathrm{O}_{7}$-liuoksella $\left(\mathrm{Zn}_{\mathrm{py}}\right)$ ja sen jälkeen samasta näytteestä $0,05 \mathrm{M}$ oksalaattiliuoksella ( $\mathrm{pH} 2,9)\left(\mathrm{Zn}_{\mathrm{ox}}\right) \mathrm{Fe}$ - ja Al-oksidien sitomaksi arveltua sinkiä. Summan $\mathrm{Zn}_{\text {py }}+\mathrm{Zn}_{\mathrm{ox}}$ katsottiin kuvastavan maan sekundaaristen $\mathrm{Zn}$-varojen suuruutta vastakohtana rapautumattomien mineraalien sisältämälle sinkille. Sekundaarisen sinkin määrä (mediaani $5,9 \mathrm{mg} \mathrm{dm}^{-3}, \mathrm{n}=106$ ) oli kaikissa maalajeissa samaa suuruusluokkaa. Sen sijaan sekundaarisen sinkin osuus (\%) $\mathrm{Zn}_{\text {tot }}$ :sta oli pienin savimaissa (mediaani $5 \%$ ) ja suurin turvemaissa (mediaani $49 \%$ ), mikä kuvastaa maan $\mathrm{Zn}_{\text {tot }}: \mathrm{n}$ määrissä olevia eroja. Maan sinkkiä uutettiin myös viljavuusanalyysissä käytettävällä happamalla ammoniumasetaatti - EDTA -liuoksella $\left(0,5 \mathrm{M} \mathrm{CH}_{3} \mathrm{COOH}\right.$, $0,5 \mathrm{M} \mathrm{CH}_{3} \mathrm{COONH}_{4}, 0,02 \mathrm{M} \mathrm{Na}_{2}$-EDTA, pH 4,65). Menetelmällä saadut tulokset $\left(\mathrm{Zn}_{\mathrm{Ac}}\right.$, mediaani $2,9 \mathrm{mg} \mathrm{dm}^{-3}$, vaihteluväli $0,6-29,9 \mathrm{mg} \mathrm{dm}^{-3}, \mathrm{n}=106$ ) olivat kiinteässä vuorosuh-

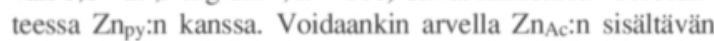
vesiliukoista, vaihtuvaa, orgaanisen aineksen ja Fe- ja $\mathrm{Al}$-oksidien sitomaa sinkkiä. $\mathrm{Zn}_{\mathrm{Ac}}$ :n pitoisuus oli muokkauskerroksessa lähes poikkeuksetta suurempi kuin jankossa.

Astiakokeessa, jossa kasvatettiin neljä satoa raiheinää, ei maan $\mathrm{Zn}$-varoja saatu ehdytetyiksi, vaikka raiheinän sinkinsaanti vähenikin muutamista turvemaista kokeen loppua kohti. Kasvit ottivat $2-68 \%$ (mediaani $26 \%, \mathrm{n}=107$ ) sekundaarisen sinkin $\left(\mathrm{Zn}_{\text {py }}+\mathrm{Zn}_{\text {ox }}\right)$ varoista. Suhteellisesti runsaimmin $\mathrm{Zn}$-varat ehtyivät happamista, niukasti sinkkiä sisältävistä turvemaista ja muutamista karkeimmista kivennäismaista. Suhteellisesti vähiten $\mathrm{Zn}$-varat ehtyivät runsaasti $\mathrm{Zn}_{\mathrm{Ac}}$ sisältävistä maista sekä niukemmin $\mathrm{Zn}_{\mathrm{Ac}}$ sisältävistä neutraaleista maista. $\mathrm{Zn}_{\mathrm{Ac}}$ kuvasti melko hyvin raiheinän $\mathrm{Zn}$ - ottoa, joskin menetelmä näyttää hieman yliarvioivan kasvin sinkinsaantia maista, joissa oli kesimääräistä korkeampi $\mathrm{pH}$. Kivennäismaissa $\mathrm{pH}$ sääteli selvimmin sitä, kuinka tehokkaasti sinkkisulfaattina maahan lisätty $\mathrm{Zn}\left(10 \mathrm{mg} \mathrm{dm}^{-3}\right)$ kohotti raiheinän $\mathrm{Zn}$-pitoisuutta. Maan $\mathrm{pH}: \mathrm{n}$ kohotessa $\mathrm{Zn}$-lannoituksen teho heikkeni. $\mathrm{Zn}_{\mathrm{Ac}}: \mathrm{n}$ niukkuus maassa lisäsi $\mathrm{Zn}$ lannoituksen tehoa. Zn-lannoitus kohotti raiheinän Zn-pitoisuutta eniten niissä eloperäisissä maissa, joiden Zn-varoilla oli taipumus ehtyä suhteellisesti voimakkaimmin.

Sinkkilannoituksen vaikutusta timotein Zn-pitoisuuteen tutkittiin kahdessa kaksivuotisessa kenttäkokeessa savi- ja hietamaalla. Ilman Zn-lannoitusta kasvaneen timoitein keskimääräinen $\mathrm{Zn}$-pitoisuus oli savimaalla $28 \mathrm{mg} \mathrm{kg}^{-1}$ ja hietamaalla $35 \mathrm{mg} \mathrm{kg}^{-1}$. Sinkkisulfaattina tai rakeisen kipsin ja sinkkisulfaatin seoksena kokeen alussa annettu 3 ja $6 \mathrm{~kg} \mathrm{Zn}$ $\mathrm{ha}^{-1}$ lannoitus nosti timotein sinkkipitoisuutta 3 ja $7 \mathrm{mg} \mathrm{kg}^{-1}$. Kun näitä lannoitteita levitettiin nurmen pintaan ensimmäisen sadonkorjuuvuoden keväällä, oli vaikutus sama kuin nurmen kylvön yhteydessä maahan muokatulla lannoituksella. Nurmen pintaan levitettyjen sinkkiä sisältävien NPK-lannoitteiden $\mathrm{Zn}$-lannoitusvaikutus oli vähäinen. Kolmivuotisissa kenttäkokeissa ilman $\mathrm{Zn}$-lannoitusta viljellyn ohran jyvien $\mathrm{Zn}$-pitoisuus oli savimaalla $29 \mathrm{mg} \mathrm{kg}^{-1}$, hietamaalla $18 \mathrm{mg} \mathrm{kg}^{-1}$ ja multamaalla $39 \mathrm{mg} \mathrm{kg}^{-1}$. Zn-lannoitus $\left(5,4 \mathrm{~kg} \mathrm{ha}^{-1}\right.$ kerralla kokeen alussa tai yhteensä $4,8-5,4 \mathrm{~kg} \mathrm{ha}^{-1}$ kolmessa osassa) kohotti jyvän $\mathrm{Zn}$-pitoisuutta savimaalla ( $\mathrm{pH} \mathrm{5,8)} 5 \mathrm{mg} \mathrm{kg}^{-1}$, mutta sillä ei ollut vaikutusta hietamaalla ( $\mathrm{pH} \mathrm{7,1)} \mathrm{eikä}$

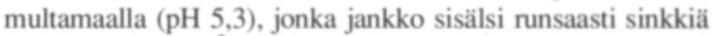
$\left(\mathrm{Zn}_{\mathrm{Ac}} 17,2 \mathrm{mg} \mathrm{dm}^{-3}\right)$. Lehtilannoitteena annettu $\mathrm{Na}_{2} \mathrm{Zn}$-EDTA $(1,8 \mathrm{~kg} \mathrm{Zn} \mathrm{ha-1} \mathrm{vuosittain)} \mathrm{kohotti} \mathrm{jyvän} \mathrm{Zn}$-pitoisuutta kaikissa kokeissa $3-4 \mathrm{mg} \mathrm{kg}^{-1}$. Hietamaahan sinkkisulfaattina annettu runsaampi lannoitus ( 15 ja $30 \mathrm{~kg} \mathrm{Zn} \mathrm{ha}^{-1}$ ) kohotti jyvän $\mathrm{Zn}$-pitoisuutta 5 tai $7 \mathrm{mg} \mathrm{kg}^{-1}$, mutta vaikutusta ei havaittu enää seuraavana vuonna, mikä osoittaa sinkin heikkoa käyttökelpoisuutta kyseisellä neutraalilla maalla. Sinkkilannoitus ei vaikuttanut timotein tai ohran sadon määrään.

Maan $\mathrm{pH}$ vaikuttaa ratkaisevasti sekä luontaisen että varsinkin lannoitteena annetun sinkin käyttökelpoisuuteen. Tästä syystä maan sinkkianalyysin $\left(\mathrm{Zn}_{\mathrm{Ac}}\right)$ tulkinnassa ja lannoitussuosituksia annettaessa olisi otettava huomioon myös maan $\mathrm{pH}$. Neutraaleilla mailla on turha antaa $\mathrm{Zn}$-lannoitusta maahan sen vähäisen vaikutuksen takia; niillä on mieluummin käytettävä lehtilannoitusta. Happamammissa oloissa myös maahan annettu lannoitus kohottaa kasvien $\mathrm{Zn}$-pitoisuutta. 
Soils used in the methodological studies

\begin{tabular}{|c|c|c|c|c|c|c|}
\hline \multirow{2}{*}{$\begin{array}{l}\text { Number and } \\
\text { location }\end{array}$} & \multirow[t]{2}{*}{ Soil class } & \multicolumn{3}{|c|}{ Particle size composition $\mu \mathrm{m}, \%$} & \multirow{2}{*}{$\begin{array}{c}\text { Organic C } \\
\%\end{array}$} & \multirow[t]{2}{*}{$\mathrm{pH}$} \\
\hline & & $<2$ & $2-20$ & $20-60$ & & \\
\hline 201 Kirkkonummi & Heavy clay & 65 & 28 & 6 & 6.6 & 5.4 \\
\hline 202 Măntsălă & Silty clay & 54 & 31 & 5 & 4.0 & 5.6 \\
\hline 203 Liljendahl & Silty clay & 52 & 25 & 6 & 2.5 & 5.5 \\
\hline 204 Tarvasjoki & Silty clay & 40 & 41 & 14 & 2.5 & 5.7 \\
\hline 205 Tammisaari & Sandy clay & 39 & 22 & 18 & 5.1 & 6.8 \\
\hline 206 Lapinjärvi & Very fine sand & 28 & 26 & 23 & 2.7 & 5.4 \\
\hline 207 Pălkäne & Very fine sand & 23 & 31 & 31 & 3.1 & 5.8 \\
\hline 208 Siuntio & Very fine sand & 20 & 28 & 17 & 1.5 & 5.7 \\
\hline 209 Helsinki & Very fine sand & 20 & 20 & 34 & 2.7 & 4.9 \\
\hline 210 Koski Hl & Silt & 17 & 43 & 21 & 3.7 & 5.2 \\
\hline 211 Vihti & Fine sand & 10 & 6 & 8 & 1.5 & 4.5 \\
\hline 212 Pălkăne & Mull & 34 & 41 & 15 & 27.0 & 5.3 \\
\hline 213 Koski Hl & Mull & 22 & 48 & 18 & 28.0 & 6.8 \\
\hline
\end{tabular}


Characteristics of the soils of surface soil material. $\mathrm{Fe}_{\mathrm{ox}}$ and $\mathrm{Al}_{\mathrm{ox}}$ stand for oxalate-extractable $\mathrm{Fe}$ and $\mathrm{Al}$, respectively.

\begin{tabular}{|c|c|c|c|c|c|c|c|c|c|c|}
\hline \multirow{2}{*}{$\begin{array}{l}\text { Number and } \\
\text { location }\end{array}$} & \multirow[t]{2}{*}{ Soil class } & \multirow[t]{2}{*}{$\mathrm{pH}$} & \multirow{2}{*}{$\underset{\%}{\text { Organic }}$ C } & \multicolumn{4}{|c|}{ Particle size composition $\mu \mathrm{m}, \%$} & \multirow{2}{*}{\multicolumn{2}{|c|}{$\underset{\mathrm{mmol} \mathrm{kg-1}}{\mathrm{Fe}_{\mathrm{ox}}} \underset{\mathrm{Al}_{\mathrm{ox}}}{ }$}} & \multirow{2}{*}{$\begin{array}{c}\text { Bulk } \\
\text { density } \\
\mathrm{kg} \mathrm{dm}^{-3}\end{array}$} \\
\hline & & & & $<2$ & $2-20$ & $20-60$ & $>60$ & & & \\
\hline \multicolumn{11}{|l|}{ Clay soils: } \\
\hline 1 Somero & Heavy clay & 6.8 & 2.9 & 74 & 17 & 3 & 6 & 106 & 71 & 0.98 \\
\hline 2 Somero & Heavy clay & 5.3 & 7.7 & 67 & 24 & 4 & 5 & 134 & 172 & 0.76 \\
\hline 3 Somero & Heavy clay & 6.1 & 3.0 & 67 & 18 & 5 & 10 & 126 & 75 & 0.98 \\
\hline 4 Kylmäkoski & Heavy clay & 5.9 & 4.7 & 66 & 19 & 9 & 6 & 93 & 141 & 0.94 \\
\hline 5 Somero & Heavy clay & 6.4 & 2.2 & 66 & 8 & 4 & 22 & 118 & 73 & 1.03 \\
\hline 6 Jokioinen & Heavy clay & 7.0 & 2.0 & 64 & 10 & 5 & 21 & 80 & 70 & 1.04 \\
\hline 7 Ypäjä & Heavy clay & 6.0 & 2.3 & 63 & 22 & 6 & 9 & 100 & 55 & 1.00 \\
\hline 8 Kirkkonummi & Gyttja clay & 5.7 & 4.1 & 58 & 34 & 5 & 3 & 76 & 124 & 0.88 \\
\hline 9 Loimaa & Clay loam & 5.8 & 2.9 & 56 & 23 & 7 & 14 & 70 & 69 & 1.05 \\
\hline 10 Kirkkonummi & Gyttja clay & 4.6 & 3.7 & 56 & 30 & 11 & 3 & 121 & 84 & 0.85 \\
\hline 11 Vehkalahti & Clay loam & 6.0 & 1.9 & 55 & 24 & 13 & 8 & 87 & 57 & 1.10 \\
\hline 12 Vihti & Gyttja clay & 5.4 & 9.5 & 51 & 41 & 7 & 1 & 79 & 133 & 0.76 \\
\hline 13 Perniö & Silty clay & 6.7 & 3.2 & 51 & 31 & 11 & 7 & 172 & 66 & 0.88 \\
\hline 14 Loimaa mlk & Silty clay & 5.9 & 2.4 & 49 & 44 & 3 & 4 & 92 & 69 & 1.03 \\
\hline 16 Koski TL & Clay loam & 5.7 & 2.0 & 45 & 31 & 15 & 9 & 79 & 57 & 1.14 \\
\hline 17 Helsinki & Clay loam & 6.4 & 3.5 & 43 & 22 & 21 & 14 & 102 & 57 & 1.05 \\
\hline 18 Valkeala & Clay loam & 6.2 & 2.5 & 42 & 37 & 17 & 4 & 55 & 49 & 1.12 \\
\hline 19 Valkeala & Clay loam & 6.5 & 2.4 & 42 & 36 & 18 & 4 & 60 & 47 & 1.12 \\
\hline 20 Mustasaari & Silty clay & 5.2 & 6.1 & 40 & 43 & 14 & 3 & 166 & 96 & 0.69 \\
\hline 21 Kuhmoinen & Clay loam & 6.4 & 3.2 & 39 & 37 & 12 & 12 & 80 & 74 & 0.85 \\
\hline 22 Vehkalahti & Clay loam & 6.1 & 1.2 & 39 & 32 & 19 & 10 & 90 & 55 & 1.08 \\
\hline 23 Tampere & Silty clay & 6.2 & 2.2 & 37 & 54 & 5 & 4 & 83 & 85 & 0.90 \\
\hline 24 Valkeala & Silty clay & 5.7 & 2.6 & 35 & 31 & 14 & 20 & 69 & 57 & 1.01 \\
\hline 25 Valkeala & Silty clay & 5.9 & 1.4 & 35 & 31 & 15 & 19 & 87 & 51 & 1.14 \\
\hline 26 Ylihärmă & Silty clay & 5.0 & 7.0 & 32 & 45 & 18 & 5 & 144 & 86 & 0.72 \\
\hline \multicolumn{11}{|c|}{ Coarse mineral soils and moraines: } \\
\hline 27 Vihti & Loam & 6.3 & 2.0 & 29 & 34 & 22 & 15 & 60 & 56 & 1.18 \\
\hline 28 Korpilahti & Silt & 6.6 & 0.8 & 27 & 51 & 17 & 5 & 65 & 34 & 1.05 \\
\hline 29 Vihti & Loam & 5.7 & 2.0 & 27 & 27 & 11 & 35 & 58 & 52 & 1.16 \\
\hline 30 Laihia & Loam & 6.2 & 3.1 & 25 & 37 & 32 & 6 & 91 & 50 & 1.00 \\
\hline 31 Tarvasjoki & Loam & 5.2 & 2.2 & 25 & 32 & 28 & 15 & 90 & 46 & 1.13 \\
\hline 32 Luumäki & Loam & 6.4 & 2.4 & 24 & 45 & 19 & 12 & 59 & 33 & 1.00 \\
\hline 33 Ylistaro & Loam & 6.3 & 2.3 & 24 & 46 & 16 & 14 & 94 & 49 & 1.01 \\
\hline 34 Pyhăselkä & Loam & 5.0 & 2.7 & 23 & 41 & 23 & 13 & 88 & 57 & 0.94 \\
\hline 35 Isokyrö & Silt & 6.8 & 2.1 & 23 & 52 & 21 & 4 & 128 & 36 & 1.00 \\
\hline 36 Ylivieska & Loam & 5.8 & 2.7 & 22 & 44 & 27 & 7 & 80 & 37 & 0.97 \\
\hline 37 Huittinen & Loam & 6.2 & 2.0 & 22 & 36 & 23 & 19 & 77 & 43 & 1.01 \\
\hline 38 Hollola & Silt & 6.4 & 4.8 & 21 & 64 & 12 & 3 & 87 & 96 & 0.77 \\
\hline 39 Luumăki & Silt & 6.1 & 3.1 & 20 & 50 & 19 & 11 & 57 & 26 & 0.95 \\
\hline 40 Tervola & Loam & 4.2 & 5.3 & 16 & 45 & 27 & 12 & 210 & 29 & 0.84 \\
\hline 41 Alavieska & Sandy moraine & 6.0 & 4.0 & 16 & 24 & 10 & 50 & 103 & 48 & 1.04 \\
\hline 42 Maalahti & Very fine sand & 5.0 & 3.1 & 16 & 27 & 48 & 9 & 56 & 56 & 0.96 \\
\hline 43 Vihti & Loam & 6.2 & 1.9 & 15 & 39 & 33 & 13 & 51 & 41 & 1.08 \\
\hline 44 Lammi & Loam & 6.0 & 2.7 & 12 & 42 & 37 & 9 & 59 & 137 & 0.87 \\
\hline 45 Alavieska & Sandy moraine & 6.2 & 3.0 & 11 & 21 & 28 & 40 & 115 & 39 & 1.07 \\
\hline 46 Lapinlahti & Sandy moraine & 6.1 & 1.9 & 11 & 17 & 10 & 62 & 50 & 40 & 1.18 \\
\hline 47 Sonkajărvi & Fine sand & 5.6 & 2.9 & 9 & 18 & 21 & 52 & 62 & 57 & 1.08 \\
\hline 48 Kitee & Very fine sand & 5.9 & 2.5 & 9 & 35 & 41 & 15 & 63 & 133 & 1.03 \\
\hline 49 Maaninka & Fine sand & 5.8 & 1.8 & 8 & 19 & 29 & 44 & 66 & 49 & 1.09 \\
\hline 50 Sotkamo & Silt & 6.3 & 1.3 & 8 & 59 & 17 & 16 & 72 & 55 & 0.99 \\
\hline 51 Vihti & Sandy moraine & 6.4 & 2.4 & 8 & 9 & 7 & 76 & 45 & 70 & 1.21 \\
\hline 52 Ylivieska & Sandy moraine & 5.2 & 3.1 & 7 & 13 & 23 & 57 & 31 & 45 & 1.10 \\
\hline 53 Siikajoki & Sandy moraine & 6.3 & 2.6 & 7 & 9 & 16 & 68 & 85 & 32 & 1.31 \\
\hline 54 Saari & Sandy moraine & 6.4 & 3.3 & 6 & 15 & 30 & 49 & 231 & 28 & 1.14 \\
\hline
\end{tabular}




\begin{tabular}{|c|c|c|c|c|c|c|c|c|c|c|}
\hline \multirow{2}{*}{$\begin{array}{l}\text { Number and } \\
\text { location }\end{array}$} & \multirow[t]{2}{*}{ Soil class } & \multirow[t]{2}{*}{$\mathrm{pH}$} & \multirow{2}{*}{$\underset{\%}{\text { Organic }}$} & \multicolumn{4}{|c|}{ Particle size composition $\mu \mathrm{m}, \%$} & \multirow{2}{*}{$\begin{array}{l}\mathrm{Fe}_{\mathrm{ox}} \\
\mathrm{mmol}\end{array}$} & \multirow{2}{*}{$\underset{\mathrm{kg}^{-1}}{\mathrm{Al}_{\mathrm{ox}}}$} & \multirow{2}{*}{$\begin{array}{c}\text { Bulk } \\
\text { density } \\
\mathrm{kg} \mathrm{dm}^{-3}\end{array}$} \\
\hline & & & & $<2$ & $2-20$ & $20-60$ & $>60$ & & & \\
\hline 55 Liperi & Sandy moraine & 6.0 & 3.0 & 6 & 14 & 27 & 53 & 29 & 81 & 1.11 \\
\hline 56 Joroinen & Fine sand & 6.3 & 1.7 & 6 & 15 & 16 & 63 & 39 & 64 & 1.16 \\
\hline 57 Jyväskylä mlk & Very fine sand & 5.6 & 1.5 & 6 & 29 & 51 & 14 & 61 & 122 & 1.10 \\
\hline 58 Lapua & Fine sand & 6.1 & 4.2 & 5 & 10 & 25 & 60 & 22 & 51 & 1.00 \\
\hline 59 Ristiina & Sandy moraine & 5.8 & 3.2 & 5 & 12 & 17 & 66 & 47 & 109 & 1.16 \\
\hline 60 Ristiina & Sandy moraine & 6.1 & 2.0 & 5 & 13 & 9 & 73 & 41 & 104 & 1.26 \\
\hline 61 Hammarland & Sandy moraine & 6.9 & 0.7 & 5 & 3 & 3 & 89 & 17 & 9 & 1.43 \\
\hline 62 Kauhava & Sandy moraine & 6.7 & 3.4 & 4 & 8 & 43 & 45 & 19 & 43 & 1.06 \\
\hline 63 Liminka & Sandy moraine & 5.8 & 2.7 & 4 & 8 & 46 & 42 & 55 & 25 & 1.15 \\
\hline 64 Vihti & Fine sand & 6.5 & 1.9 & 4 & 4 & 6 & 86 & 46 & 104 & 1.30 \\
\hline 65 Jalasjärvi & Fine sand & 6.3 & 2.0 & 4 & 7 & 24 & 65 & 25 & 35 & 1.10 \\
\hline 66 Muhos & Fine sand & 5.4 & 6.1 & 3 & 6 & 5 & 86 & 10 & 74 & 0.89 \\
\hline 67 Närpiő & Fine sand & 5.2 & 5.1 & 3 & 4 & 38 & 55 & 33 & 57 & 0.96 \\
\hline 68 Pieksămäki & Sandy moraine & 5.9 & 2.6 & 3 & 11 & 28 & 58 & 19 & 32 & 1.10 \\
\hline 69 Ruovesi & Fine sand & 7.4 & 1.5 & 3 & 4 & 16 & 77 & 48 & 122 & 1.26 \\
\hline 70 Ähtäri & Sandy moraine & 5.8 & 2.2 & 3 & 7 & 10 & 80 & 42 & 178 & 1.22 \\
\hline 71 Harjavalta & Fine sand & 7.1 & 2.1 & 3 & 8 & 21 & 68 & 11 & 16 & 1.10 \\
\hline 72 Hammarland & Fine sand & 4.9 & 2.0 & 2 & 3 & 4 & 91 & 17 & 23 & 1.24 \\
\hline 73 Kuusamo & Sandy moraine & 5.4 & 2.7 & 2 & 8 & 16 & 74 & 95 & 10 & 1.14 \\
\hline 74 Sotkamo & Sandy moraine & 5.3 & 2.3 & 1 & 4 & 5 & 90 & 18 & 51 & 1.26 \\
\hline \multicolumn{11}{|l|}{ Organogenic soils: } \\
\hline 75 Sotkamo & Mull & 6.2 & 12.4 & 2 & 11 & 43 & 44 & 88 & 40 & 0.77 \\
\hline 76 Sotkamo & Mull & 5.1 & 12.8 & 5 & 24 & 15 & 56 & 94 & 95 & 0.71 \\
\hline 77 Maaninka & Mull & 5.5 & 14.4 & 22 & 44 & 14 & 20 & 120 & 117 & 0.55 \\
\hline 78 Savitaipale & Mull & 5.7 & 14.8 & 10 & 17 & 29 & 44 & 70 & 86 & 0.69 \\
\hline 15 Vihti & Mull & 5.0 & 18.3 & 27 & 56 & 14 & 3 & 93 & 225 & 0.64 \\
\hline 79 Vihti & Mull & 5.1 & 19.0 & 75 & 20 & 3 & 2 & 54 & 266 & 0.76 \\
\hline 80 Muhos & Mull & 5.8 & 20.3 & 4 & 11 & 10 & 75 & 249 & 17 & 0.70 \\
\hline 81 Sievi & Mull & 4.8 & 21.3 & 14 & 57 & 24 & 5 & 131 & 85 & 0.54 \\
\hline 82 Ylivieska & Mull & 5.0 & 21.4 & 25 & 55 & 16 & 4 & 147 & 127 & 0.57 \\
\hline 83 Sotkamo & Mull & 5.6 & 21.5 & 42 & 48 & 10 & 0 & 108 & 120 & 0.61 \\
\hline 84 Eno & Mull & 5.8 & 21.9 & 8 & 20 & 17 & 55 & 235 & 42 & 0.58 \\
\hline 85 Honkajoki & Mull & 5.7 & 22.0 & 9 & 42 & 28 & 21 & 65 & 53 & 0.59 \\
\hline 86 Savitaipale & Mull & 5.8 & 22.5 & 16 & 25 & 28 & 31 & 87 & 72 & 0.60 \\
\hline 87 Forssa & Mull & 5.5 & 22.6 & 68 & 19 & 7 & 6 & 145 & 151 & 0.72 \\
\hline 88 Tammela & Carex peat & 5.6 & 23.9 & n.d. & n.d. & n.d. & n.d. & 102 & 74 & 0.55 \\
\hline 89 Sotkamo & Carex peat & 5.0 & 24.3 & n.d. & n.d. & n.d. & n.d. & 135 & 67 & 0.46 \\
\hline 90 Nărpiō & Carex peat & 4.7 & 25.1 & n.d. & n.d. & n.d. & n.d. & 252 & 26 & 0.54 \\
\hline 91 Jokioinen & Carex peat & 6.2 & 28.7 & n.d. & n.d. & n.d. & n.d. & 122 & 97 & 0.52 \\
\hline 92 Joroinen & Carex peat & 5.0 & 29.9 & n.d. & n.d. & n.d. & n.d. & 107 & 222 & 0.48 \\
\hline 93 Sonkajărvi & Carex peat & 4.5 & 30.2 & n.d. & n.d. & n.d. & n.d. & 100 & 100 & 0.29 \\
\hline 94 Långelmăki & Carex peat & 5.2 & 32.3 & n.d. & n.d. & n.d. & n.d. & 82 & 249 & 0.44 \\
\hline 95 Pyhăselkă & Ligno Carex peat & 5.5 & 34.0 & n.d. & n.d. & n.d. & n.d. & 232 & 28 & 0.44 \\
\hline 96 Sotkamo & Ligno Carex peat & 4.6 & 38.0 & n.d. & n.d. & n.d. & n.d. & 90 & 94 & 0.35 \\
\hline 97 Sotkamo & Carex peat & 5.5 & 38.8 & n.d. & n.d. & n.d. & n.d. & 132 & 154 & 0.31 \\
\hline 98 Pudasjărvi & Ligno Carex peat & 4.9 & 39.8 & n.d. & n.d. & n.d. & n.d. & 223 & 76 & 0.27 \\
\hline 99 Yli-Ii & Ligno Carex peat & 5.5 & 40.5 & n.d. & n.d. & n.d. & n.d. & 202 & 29 & 0.26 \\
\hline 100 Rantsila & Ligno Carex peat & 3.8 & 40.5 & n.d. & n.d. & n.d. & n.d. & 147 & 83 & 0.36 \\
\hline 101 Vaala & Ligno Carex peat & 6.0 & 45.0 & n.d. & n.d. & n.d. & n.d. & 165 & 48 & 0.31 \\
\hline 102 Kuusamo & $\begin{array}{l}\text { Sphagnum } \\
\text { Carex peat }\end{array}$ & 5.5 & 45.0 & n.d. & n.d. & n.d. & n.d. & 95 & 10 & 0.27 \\
\hline 103 Valtimo & Ligno Carex peat & 4.8 & 47.3 & n.d. & n.d. & n.d. & n.d. & 70 & 94 & 0.30 \\
\hline 104 Säkylă & Carex peat & 4.7 & 48.0 & n.d. & n.d. & n.d. & n.d. & 29 & 64 & 0.27 \\
\hline 105 Suomussalmi & Ligno Carex peat & 4.1 & 49.2 & n.d. & n.d. & n.d. & n.d. & 44 & 53 & 0.25 \\
\hline 106 Muhos & Ligno Carex peat & 5.1 & 49.8 & n.d. & n.d. & n.d. & n.d. & 196 & 52 & 0.34 \\
\hline 107 Mikkeli & Carex peat & 4.4 & 50.4 & n.d. & n.d. & n.d. & n.d. & 62 & 205 & 0.39 \\
\hline
\end{tabular}


Some physical and chemical characteristics of soil profile samples.

Profile 1: Tarvasjoki, loam $(0-38 \mathrm{~cm})$, clay loam $(38-120 \mathrm{~cm})$

$\begin{array}{lccc}\begin{array}{l}\text { Depth } \\ \mathrm{cm}\end{array} & \begin{array}{c}\text { Clay } \\ \%\end{array} & \begin{array}{c}\text { Org. C } \\ \%\end{array} & \mathrm{pH} \\ 0-30 & 25 & 1.8 & 5.5 \\ 32-38 & 29 & 0.4 & 6.2 \\ 38-46 & 34 & 0.2 & 6.4 \\ 50-60 & 41 & 0.2 & 6.8 \\ 65-80 & 51 & 0.2 & 6.8 \\ 85-100 & 56 & 0.4 & 7.0 \\ 105-120 & 55 & 0.6 & 7.0\end{array}$

Profile 3: Vihti, silty clay $(0-60 \mathrm{~cm})$, heavy clay $(60-120 \mathrm{~cm})$

$\begin{array}{lccc}\begin{array}{l}\text { Depth } \\ \mathrm{cm}\end{array} & \begin{array}{c}\text { Clay } \\ \%\end{array} & \begin{array}{c}\text { Org. C } \\ \%\end{array} & \mathrm{pH} \\ 0-30 & 50 & 2.6 & 6.3 \\ 30-40 & 53 & 0.5 & 6.7 \\ 40-60 & 54 & 0.4 & 6.8 \\ 60-80 & 72 & 0.5 & 7.0 \\ 80-100 & 88 & 0.5 & 7.1 \\ 100-120 & 86 & 0.6 & 7.1\end{array}$

Profile 5: Sotkamo, Carex peat $(20-130 \mathrm{~cm})$, mineral soil mixed in the plough layer

$\begin{array}{lrrr}\begin{array}{l}\text { Depth } \\ \text { cm }\end{array} & \begin{array}{c}\text { Clay } \\ \%\end{array} & \begin{array}{c}\text { Org. C } \\ \%\end{array} & \text { pH } \\ 0-20 & 6 & 9.3 & 5.7 \\ 20-30 & \text { n.d. } & 52.2 & 5.4 \\ 30-40 & \text { n.d. } & 48.5 & 5.2 \\ 40-60 & \text { n.d. } & 51.8 & 5.4 \\ 60-80 & \text { n.d. } & 46.8 & 5.5 \\ 80-100 & \text { n.d. } & 39.6 & 5.5 \\ 100-120 & \text { n.d. } & 30.6 & 5.6 \\ 120-130 & \text { n.d. } & 31.5 & 5.6\end{array}$

Profile 7: Muhos, Carex peat $(0-110 \mathrm{~cm})$, fine sand $(110-125 \mathrm{~cm})$

$\begin{array}{lrrrr}\begin{array}{l}\text { Depth } \\ \text { cm }\end{array} & \begin{array}{c}\text { Fine } \\ \%\end{array} & \begin{array}{c}\text { FS } \\ \%\end{array} & \begin{array}{c}\text { Org. C } \\ \%\end{array} & \text { pH } \\ 0-30 & \text { n.d. } & \text { n.d. } & 44.7 & 5.3 \\ 30-50 & \text { n.d. } & \text { n.d. } & 55.1 & 4.7 \\ 50-70 & \text { n.d. } & \text { n.d. } & 52.1 & 4.7 \\ 70-90 & \text { n.d. } & \text { n.d. } & 55.8 & 4.9 \\ 90-110 & \text { n.d. } & \text { n.d. } & 54.2 & 5.0 \\ 110-125 & 3 & 56 & 0.2 & 5.0\end{array}$

n.d. $=$ Not determined

1) $<0.06 \mathrm{~mm}^{2)}$ Fine sand $(0.06-0.2 \mathrm{~mm})$
Profile 2: Vihti, strongly layered silt

$\begin{array}{lccc}\text { Depth } & \begin{array}{c}\text { Clay } \\ \text { cm }\end{array} & \begin{array}{c}\text { Org. C } \\ \%\end{array} & \text { pH } \\ 0-27 & 17 & 3.2 & 6.0 \\ 30-40 & 11 & 0.2 & 6.8 \\ 40-50 & 12 & 0.2 & 6.6 \\ 50-70 & 17 & 0.2 & 6.6 \\ 70-90 & 6 & 0.1 & 6.6 \\ 90-100 & 16 & 0.1 & 6.7 \\ 110-120 & 27 & 0.2 & 6.9\end{array}$

Profile 4: Sotkamo, strongly podzolized fine sand

$\begin{array}{lcccc}\begin{array}{l}\text { Depth } \\ \text { cm }\end{array} & \begin{array}{c}\text { Fine }^{1)} \\ \%\end{array} & \begin{array}{c}\text { FS }^{2)} \\ \%\end{array} & \begin{array}{c}\text { Org. C } \\ \%\end{array} & \text { pH } \\ 0-30 & 18 & 55 & 5.0 & 6.0 \\ 30-40 & 14 & 63 & 0.3 & 6.0 \\ 40-45 & 3 & 52 & 2.8 & 5.7 \\ 45-60 & 2 & 67 & 0.7 & 5.7 \\ 60-80 & 17 & 75 & 0.2 & 5.6 \\ 80-110 & 11 & 82 & 0.1 & 5.6 \\ 110-120 & 35 & 64 & 0.1 & 5.9\end{array}$

Profile 6: Jokioinen, Carex peat $(0-40 \mathrm{~cm})$, mud $(40-50 \mathrm{~cm})$, heavy clay $(50-70 \mathrm{~cm})$

$\begin{array}{lrrr}\begin{array}{l}\text { Depth } \\ \mathrm{cm}\end{array} & \begin{array}{c}\text { Clay } \\ \%\end{array} & \begin{array}{c}\text { Org. C } \\ \%\end{array} & \mathrm{pH} \\ 0-25 & \text { n.d. } & 30.8 & 6.0 \\ 30-40 & \text { n.d. } & 30.0 & 5.5 \\ 40-45 & 82 & 16.7 & 5.7 \\ 50-70 & 90 & 1.0 & 6.0 \\ 70-80 & 88 & 0.8 & 6.0\end{array}$


Characteristics of soil sample pairs consisting of plough layer $\left(A_{p}\right)$ and subsoil $(B)$ samples

\begin{tabular}{|c|c|c|c|c|c|c|c|c|}
\hline \multirow{2}{*}{$\begin{array}{l}\text { Location and } \\
\text { number }\end{array}$} & \multirow[t]{2}{*}{ Horizon } & \multirow[t]{2}{*}{ Soil class } & \multicolumn{3}{|c|}{ Particle size composition $\mu \mathrm{m}, \%$} & \multirow{2}{*}{$\begin{array}{c}\text { Org. C } \\
\% 0\end{array}$} & \multirow[t]{2}{*}{$\mathrm{pH}$} & \multirow{2}{*}{$\frac{\mathrm{Zn}_{\mathrm{Ac}}}{\mathrm{mg} \mathrm{dm}^{-3}}$} \\
\hline & & & $<2$ & $2-20$ & $20-60$ & & & \\
\hline \multirow[t]{2}{*}{ Somero $1^{1}$} & $A_{p}$ & Heavy clay & 74 & 17 & 3 & 2.9 & 6.8 & 6.1 \\
\hline & B & Heavy clay & 73 & 12 & 5 & 0.6 & 6.8 & 3.3 \\
\hline \multirow[t]{2}{*}{ Somero $2^{1}$} & $A_{p}$ & Heavy clay & 67 & 24 & 4 & 7.7 & 5.3 & 3.3 \\
\hline & B & Heavy clay & 66 & 22 & 2 & 1.1 & 5.5 & 0.9 \\
\hline \multirow[t]{2}{*}{ Jokioinen $6^{\prime}$} & $A_{p}$ & Heavy clay & 64 & 10 & 5 & 2.0 & 7.0 & 2.8 \\
\hline & B & Heavy clay & 91 & 5 & 2 & 0.6 & 6.5 & 2.1 \\
\hline \multirow[t]{2}{*}{ Somero $3^{1}$} & $A_{p}$ & Heavy clay & 67 & 18 & 5 & 3.0 & 6.1 & 5.6 \\
\hline & B & Heavy clay & 75 & 14 & 5 & 0.5 & 7.0 & 2.0 \\
\hline \multirow[t]{2}{*}{ Loimaa mlk 14 ' } & $A_{p}$ & Silty clay & 49 & 44 & 3 & 2.4 & 5.9 & 4.9 \\
\hline & B & Heavy clay & 60 & 31 & 4 & 0.5 & 6.5 & 2.1 \\
\hline \multirow[t]{2}{*}{ Koski TL 16' } & $A_{p}$ & Silty clay & 45 & 31 & 15 & 2.0 & 5.7 & 3.7 \\
\hline & B & Silty clay & 54 & 27 & 16 & 0.3 & 6.6 & 1.5 \\
\hline \multirow[t]{2}{*}{ Kestilä } & $A_{p}$ & Very fine sand & 6 & 16 & 52 & 2.6 & 5.3 & 1.3 \\
\hline & B & Very fine sand & 5 & 14 & 54 & 2.1 & 5.2 & 0.6 \\
\hline \multirow[t]{2}{*}{ Maaninka $49 !$} & $A_{p}$ & Fine sand & 8 & 19 & 29 & 1.8 & 5.8 & 5.6 \\
\hline & B & Very fine sand & 6 & 21 & 40 & 0.4 & 6.3 & 0.3 \\
\hline \multirow[t]{2}{*}{ Muhos } & $A_{p}$ & Fine sand & 2 & 4 & 4 & 5.8 & 5.5 & 1.5 \\
\hline & B & Fine sand & 2 & 2 & 3 & 0.4 & 4.9 & 0.9 \\
\hline \multirow[t]{2}{*}{ Rantsila } & $A_{p}$ & Loam & 12 & 47 & 36 & 7.3 & 6.4 & 1.3 \\
\hline & B & Carex peat & n.d. & n.d. & n.d. & 35.6 & 4.8 & 1.1 \\
\hline \multirow[t]{2}{*}{ Forssa $87^{1}$} & $A_{p}$ & Mull & 68 & 19 & 7 & 22.6 & 5.7 & 3.2 \\
\hline & B & Heavy clay & 74 & 14 & 8 & 2.5 & 6.0 & 4.0 \\
\hline \multirow[t]{2}{*}{ Sotkamo $75^{1}$} & $A_{p}$ & Mull & 2 & 11 & 43 & 12.4 & 6.2 & 2.0 \\
\hline & B & Carex peat & n.d. & n.d. & n.d. & 50.5 & 5.8 & 0.5 \\
\hline \multirow[t]{2}{*}{ Maaninka $77^{1}$} & $A_{p}$ & Mull & 22 & 44 & 14 & 14.4 & 5.5 & 2.4 \\
\hline & B & Carex peat & n.d. & n.d. & n.d. & 43.8 & 5.4 & 0.5 \\
\hline \multirow[t]{2}{*}{ Sonkajärvi 93ı } & $A_{p}$ & Carex peat & n.d. & n.d. & n.d. & 30.2 & 4.5 & 3.3 \\
\hline & B & Carex peat & n.d. & n.d. & n.d. & 48.0 & 4.6 & 0.4 \\
\hline \multirow[t]{2}{*}{ Kestilä } & $A_{p}$ & Carex peat & n.d. & n.d. & n.d. & 42.3 & 5.2 & 4.1 \\
\hline & B & Carex peat & n.d. & n.d. & n.d. & 48.5 & 4.7 & 0.8 \\
\hline
\end{tabular}

' Refers to the number of the $A_{p}$ horizon sample in the surface soil material (Appendix 2) n.d. = Not determined 
Characteristics of the surface soils: total $\mathrm{Zn}\left(\mathrm{Zn}_{\mathrm{tot}}\right)$, and $\mathrm{Zn}$ extracted with $\mathrm{MgCl}_{2}\left(\mathrm{Zn}_{\mathrm{ex}}\right)$, pyrophosphate $\left(\mathrm{Zn}_{\mathrm{py}}\right)$, oxalate $\left(\mathrm{Zn}_{\mathrm{ox}}\right)$ and acetic acid-ammonium acetate -EDTA $\left(\mathrm{Zn}_{\mathrm{Ac}}\right) . \mathrm{Zn}_{\mathrm{py}}$ and $\mathrm{Zn}_{\mathrm{ox}}$ were extracted sequentially.

\begin{tabular}{lllllr}
\hline Number and location & $\mathrm{Zn}_{\text {tot }}$ & $\mathrm{Zn}_{\text {ex }}$ & $\mathrm{Zn}_{\text {py }}$ & $\mathrm{Zn}_{\mathrm{ox}}$ & $\mathrm{Zn}_{\mathrm{Ac}}$ \\
\hline
\end{tabular}

Clay soils:

1 Somero
2 Somero
3 Somero
4 Kylmăkoski
5 Somero
6 Jokioinen
7 Ypäjä
8 Kirkkonummi
9 Loimaa
10 Kirkkonummi
11 Vehkalahti
12 Vihti
13 Perniō
14 Loimaa mlk
16 Koski TL
17 Helsinki
18 Valkeala
19 Valkeala
20 Mustasaari
21 Kuhmoinen
22 Vehkalahti
23 Tampere
24 Valkeala
25 Valkeala
26 Ylihărmă

$\begin{array}{rl}186 & 1.1 \\ 168 & 3.3 \\ 171 & 1.0 \\ 122 & 1.0 \\ 189 & 1.1 \\ 187 & 0.5 \\ 150 & 1.2 \\ 157 & 1.3 \\ 146 & 2.3 \\ 108 & 2.6 \\ 148 & 1.0 \\ 66.4 & 1.5 \\ 82.8 & 0.5 \\ 147 & 2.4 \\ 147 & 2.6 \\ 190 & 4.9 \\ 104 & 0.7 \\ 115 & 1.0 \\ 102 & 3.7 \\ 202 & 0.6 \\ 134 & 1.1 \\ 146 & 0.7 \\ 140 & 3.7 \\ 137 & 1.3 \\ 82.2 & 2.7\end{array}$

Coarse mineral soils and moraines:

27 Vihti
28 Korpilahti
29 Vihti
30 Laihia
31 Tarvasjoki
32 Luumäki
33 Ylistaro
34 Pyhäselkä
35 Isokyrő
36 Ylivieska
37 Huittinen
38 Hollola
39 Luumäki
40 Tervola
41 Alavieska
42 Maalahti
43 Vihti
44 Lammi
45 Alavieska
46 Lapinlahti
47 Sonkajärvi
48 Kitee
49 Maaninka
50 Sotkamo
51 Vihti
52 Ylivieska

128

92.0

117

109

79.8

81.6

114

106

115

82.1

104

201

62.5

63.8

55.9

66.8

92.6

112

45.7

68.9

57.1

74.6

102

58.0

57.9

26.5

2.8
8.1
2.4
3.4
4.5
2.0
4.1
5.2
4.8
5.4
1.8
2.6
1.4
5.4
6.1
23.1
1.8
3.6
7.8
3.8
2.2
2.1
8.6
2.6
7.0

3.5

2.9

2.3

2.2

4.4

4.4

3.7

3.4

3.1

1.9

2.8

1.2

2.0

3.9

4.2

13.0

2.1

3.1

3.1

5.2

2.7

3.1

4.8

2.7

2.3

3.8

3.3

1.7

2.3

4.4

2.8

3.7

3.0

3.7

2.8

2.1

1.5

1.1

4.9

3.7

18.0

2.0

4.4

3.4

2.3

3.3

1.6

6.3

3.4

2.9

1.0

0.8

1.3

4.1

2.3

1.9

5.7

2.5

5.2

3.8

1.9

1.4

4.7

2.9

1.5

2.7

1.9

0.8

1.5

3.3

2.4

1.4

1.7

2.1

1.7

1.8 


\begin{tabular}{|c|c|c|c|c|c|}
\hline Number and location & $\mathrm{Zn}_{\text {tot }}$ & $\mathrm{Zn}_{\mathrm{ex}}$ & $\mathrm{Zn}_{\mathrm{py}}$ & $\mathrm{Zn}_{\mathrm{ox}}$ & $\begin{array}{c}\mathrm{Zn}_{\mathrm{Ac}} \\
\mathrm{mg} \mathrm{dm}^{-3}\end{array}$ \\
\hline 53 Siikajoki & 78.1 & 5.3 & 23.9 & 8.8 & 29.9 \\
\hline 54 Saari & 70.3 & 0.5 & 3.3 & 2.5 & 1.9 \\
\hline 55 Liperi & 45.0 & 1.2 & 4.3 & 1.4 & 2.7 \\
\hline 56 Joroinen & 76.7 & 0.8 & 4.8 & 3.4 & 2.5 \\
\hline 57 Jyväskylä mlk & 68.6 & 1.4 & 3.6 & 1.8 & 2.8 \\
\hline 58 Lapua & 35.2 & 0.8 & 4.0 & 0.9 & 2.3 \\
\hline 59 Ristiina & 62.9 & 2.4 & 7.7 & 3.6 & 5.4 \\
\hline 60 Ristiina & 64.8 & 0.8 & 4.9 & 2.7 & 3.4 \\
\hline 61 Hammarland & 37.4 & 0.4 & 1.4 & 1.2 & 1.5 \\
\hline 62 Kauhava & 37.7 & 0.6 & 3.2 & 0.9 & 2.1 \\
\hline 63 Liminka & 45.1 & 1.6 & 2.2 & 1.1 & 1.6 \\
\hline 64 Vihti & 40.6 & 0.4 & 2.1 & 1.7 & 1.5 \\
\hline 65 Jalasjărvi & 29.2 & 0.5 & 1.8 & 0.6 & 0.9 \\
\hline 66 Muhos & 14.0 & 1.1 & 2.0 & 0.5 & 1.3 \\
\hline 67 Närpiō & 43.3 & 3.1 & 5.6 & 0.9 & 4.2 \\
\hline 68 Pieksămăki & 27.0 & 0.9 & 2.6 & 0.8 & 2.0 \\
\hline 69 Ruovesi & 69.4 & 0.3 & 2.0 & 3.7 & 2.9 \\
\hline 70 Ähtäri & 52.8 & 5.6 & 13.6 & 4.0 & 12.7 \\
\hline 71 Harjavalta & 420 & 22.0 & 227 & 115 & 165 \\
\hline 72 Hammarland & 29.9 & 3.8 & 4.9 & 0.6 & 4.5 \\
\hline 73 Kuusamo & 15.1 & 2.6 & 3.5 & 1.4 & 3.8 \\
\hline 74 Sotkamo & 30.5 & 8.3 & 12.7 & 2.4 & 11.0 \\
\hline \multicolumn{6}{|l|}{ Organogenic soils: } \\
\hline 75 Sotkamo & 40.3 & 0.9 & 2.6 & 1.2 & 2.0 \\
\hline 76 Sotkamo & 31.8 & 2.4 & 5.1 & 1.1 & 2.4 \\
\hline 77 Maaninka & 63.8 & 2.5 & 5.1 & 1.2 & 2.4 \\
\hline 78 Savitaipale & 33.1 & 1.3 & 5.8 & 1.4 & 2.9 \\
\hline 15 Vihti & 67.5 & 3.3 & 8.9 & 2.3 & 5.2 \\
\hline 79 Vihti & 59.4 & 1.7 & 5.6 & 2.6 & 3.9 \\
\hline 80 Muhos & 20.0 & 1.5 & 3.3 & 1.0 & 2.2 \\
\hline 81 Sievi & 42.7 & 7.7 & 15.2 & 2.0 & 6.4 \\
\hline 82 Ylivieska & 49.8 & 2.1 & 4.7 & 1.7 & 2.1 \\
\hline 83 Sotkamo & 45.1 & 1.3 & 1.6 & 1.1 & 0.8 \\
\hline 84 Eno & 36.4 & 2.3 & 9.0 & 2.6 & 4.3 \\
\hline 85 Honkajoki & 75.8 & 7.0 & 26.9 & 3.5 & 14.0 \\
\hline 86 Savitaipale & 39.2 & 2.0 & 7.7 & 1.6 & 3.7 \\
\hline 87 Forssa & 80.1 & 1.8 & 7.9 & 2.4 & 3.2 \\
\hline 88 Tammela & 41.7 & 4.2 & 13.8 & 1.9 & 5.6 \\
\hline 89 Sotkamo & 70.8 & 7.6 & 9.3 & 2.0 & 4.9 \\
\hline 90 Nărpiō & 42.2 & 5.1 & 12.2 & 1.5 & 5.4 \\
\hline 91 Jokioinen & 63.4 & 1.7 & 8.1 & 2.3 & 3.0 \\
\hline 92 Joroinen & 48.6 & 4.8 & 12.4 & 2.4 & 5.4 \\
\hline 93 Sonkajărvi & 44.3 & 3.8 & 7.7 & 1.5 & 2.9 \\
\hline 94 Längelmäki & 32.2 & 2.4 & 4.4 & 3.1 & 1.7 \\
\hline 95 Pyhăselkă & 85.6 & 10.8 & 53.8 & 10.3 & 19.4 \\
\hline 96 Sotkamo & 27.1 & 8.4 & 13.4 & 1.5 & 3.7 \\
\hline 97 Sotkamo & 10.3 & 1.1 & 2.2 & 0.7 & 1.8 \\
\hline 98 Pudasjärvi & 18.1 & 3.3 & 6.3 & 1.6 & 1.5 \\
\hline 99 Yli-li & 24.1 & 3.5 & 14.6 & 2.2 & 3.5 \\
\hline 100 Rantsila & 34.3 & 11.0 & 16.9 & 1.7 & 5.0 \\
\hline 101 Vaala & 41.4 & 5.8 & 28.3 & 3.3 & 8.0 \\
\hline 102 Kuusamo & 32.8 & 6.0 & 26.1 & 2.7 & 6.8 \\
\hline 103 Valtimo & 11.5 & 1.9 & 2.6 & 0.5 & 0.6 \\
\hline 104 Săkylä & 22.0 & 5.6 & 15.8 & 1.6 & 4.0 \\
\hline 105 Suomussalmi & 12.3 & 4.6 & 7.3 & 1.1 & 1.6 \\
\hline 106 Muhos & 15.4 & 4.3 & 9.5 & 1.6 & 2.5 \\
\hline 107 Mikkeli & 25.3 & 8.9 & 17.5 & 1.7 & 5.5 \\
\hline
\end{tabular}


Some characteristics of the soils of two pot experiments (Sections 4.3 and 5.2.1) and the field experiments. $A_{p}=$ plough layer, $\mathrm{B}=$ subsoil $(30-35 \mathrm{~cm})$.

\begin{tabular}{|c|c|c|c|c|c|c|c|}
\hline \multirow[t]{2}{*}{ Soil and crop } & \multirow{2}{*}{$\underset{\%}{\text { Organic C }}$} & \multicolumn{4}{|c|}{ Particle size composition $\mu \mathrm{m}, \%$} & \multirow[t]{2}{*}{$\mathrm{pH}$} & \multirow{2}{*}{$\begin{array}{c}\mathrm{Zn}_{\mathrm{Ac}} \\
\mathrm{mg} \mathrm{dm}^{-3}\end{array}$} \\
\hline & & $<2$ & $2-20$ & $20-60$ & $>60$ & & \\
\hline
\end{tabular}

\section{Pot experiments}

\begin{tabular}{|c|c|c|c|c|c|c|c|}
\hline Clay loam & 2.3 & 48 & 25 & 18 & 9 & $6.2^{1}$ & 0.9 \\
\hline Fine sand & 1.0 & 7 & 3 & 46 & 44 & $5.9^{1}$ & 2.8 \\
\hline Carex peat & 27.2 & n.d. & n.d. & n.d. & n.d. & $6.2^{1}$ & 4.8 \\
\hline Sphagnum peat & 41.7 & n.d. & n.d. & n.d. & n.d. & $3.6^{1}$ & 3.7 \\
\hline
\end{tabular}

Field experiments with timothy

Clay loam $A_{p}$ B

Fine sand $A_{p}$ B

\section{4}

0.8

1.4

0.7 n.d.
2.8

3.7

Field experiments with barley

\begin{tabular}{|c|c|c|c|c|c|c|c|c|}
\hline Clay loam & $\begin{array}{l}A_{p} \\
B\end{array}$ & $\begin{array}{l}2.9 \\
0.6\end{array}$ & $\begin{array}{l}33 \\
35\end{array}$ & $\begin{array}{l}28 \\
26\end{array}$ & $\begin{array}{l}19 \\
22\end{array}$ & $\begin{array}{l}20 \\
17\end{array}$ & $\begin{array}{l}5.8 \\
6.1\end{array}$ & 2.1 \\
\hline Fine sand & $\begin{array}{l}A_{p} \\
B\end{array}$ & $\begin{array}{l}1.3 \\
0.8\end{array}$ & $\begin{array}{l}5 \\
4\end{array}$ & $\begin{array}{l}3 \\
1\end{array}$ & $\begin{array}{l}6 \\
5\end{array}$ & $\begin{array}{l}86 \\
90\end{array}$ & $\begin{array}{l}7.1 \\
6.3\end{array}$ & $\begin{array}{l}1.3 \\
0.2\end{array}$ \\
\hline Mull & $\begin{array}{l}A_{p} \\
B\end{array}$ & $\begin{array}{l}22.9 \\
32.0\end{array}$ & $\begin{array}{r}38 \\
\text { n.d. }\end{array}$ & $\begin{array}{r}45 \\
\text { n.d. }\end{array}$ & $\begin{array}{r}11 \\
\text { n.d. }\end{array}$ & $\begin{array}{r}6 \\
\text { n.d. }\end{array}$ & $\begin{array}{l}5.3 \\
5.0\end{array}$ & $\begin{array}{r}4.7 \\
17.2\end{array}$ \\
\hline
\end{tabular}

${ }^{1} \mathrm{pH}$ of the unlimed soils of the pot experiments n.d. $=$ Not determined 
Field experiment: Effect of $\mathrm{Zn}$ fertilizers on timothy in the field

Sowing: 1990

Experimental years: 1991 and 1992; two crops in each year

Method: Randomized blocks

Plot size: $2.3 \mathrm{~m} \times 10 \mathrm{~m}$

Harvested area: $1.6 \times 10 \mathrm{~m}$

Replicates: 4

Soils: Clay and fine sand

Crop: Timothy, cultivar 'Tammisto' (15 kg ha-1)

Application of $\mathrm{Zn}$ : A total of 3 or $6 \mathrm{~kg} \mathrm{ha}^{-1}$ during the experiment (5.2 kg ha-1 in NPK 18-3-12; Control: no $\mathrm{Zn}$ applied) Application of $N, P$ and $K$ : at sowing 57,34 and $37 \mathrm{~kg} \mathrm{ha}^{-1}$, respectively (NPK 14-9-10 $400 \mathrm{~kg} \mathrm{ha}^{-1}$ ); in spring and after the first harvest in each year 90-93, 31-33 and 61-65 $\mathrm{kg} \mathrm{ha}^{-1}$, respectively

Herbicide in fine sand in spring 1991: bentazone - MCPA (Basagran MCPA)

Application of $\mathrm{Zn}$ and NPK fertilizers in the field experiments with timothy:

\begin{tabular}{|c|c|c|}
\hline Treatmen & $\begin{array}{c}\mathrm{Zn} \\
\mathrm{kg} \mathrm{ha}^{-1}\end{array}$ & $\begin{array}{c}\text { NPK } \\
\text { fertilizer' }\end{array}$ \\
\hline 1. Control; no $\mathrm{Zn}$ application & 0 & 1 \\
\hline 2. $\mathrm{ZnSO}_{4} \cdot 7 \mathrm{H}_{2} \mathrm{O}$ mixed into the soil in fall 1990 & 3 & 1 \\
\hline 3. 'Sinkkilannos' " " & 3 & 1 \\
\hline 4. 'Sinkkilannos' onto the sward in spring 1991 & 3 & 1 \\
\hline 5. Coated NPK II " $" ~ "$ & $4 \times 0.75$ & 3 \\
\hline 6. $\mathrm{ZnSO}_{4} \cdot 7 \mathrm{H}_{2} \mathrm{O}$ mixed into the soil in fall 1990 & 6 & 1 \\
\hline 7. 'Sinkkilannos' " & 6 & 1 \\
\hline 8. 'Sinkkilannos' onto the sward in spring 1991 & 6 & 1 \\
\hline 9. NPK 18-3-12 onto the sward in spring and summer & $4 \times 1.3$ & 2 \\
\hline 10. Coated NPK III " & $4 \times 1.5$ & 4 \\
\hline
\end{tabular}

\footnotetext{
$11=$ NPK 17-6-12 $530 \mathrm{~kg} \mathrm{ha}^{-1}$

2 = NPK 18-3-12 $500 \mathrm{~kg} \mathrm{ha}^{-1}$, Triple superphosphate $90 \mathrm{~kg} \mathrm{ha}^{-1}$

3 = Coated NPK II $360 \mathrm{~kg} \mathrm{ha}^{-1}$, NPK 17-6-12 $170 \mathrm{~kg} \mathrm{ha}^{-1}$

4 = Coated NPK III $360 \mathrm{~kg} \mathrm{ha}^{-1}$, NPK 17-6-12 $170 \mathrm{~kg} \mathrm{ha}^{-1}$
}

Dates of farming operations:

Sowing

Spring fertilization

Harvest I/91

Summer fertilization

Harvest II/91

Spring fertilization

Harvest I/91

Summer fertilization

Harvest II/92
Clay:

Aug. 27, 1990

May 16, 1991

June 26, 1991

June 28, 1991

Aug. 13, 1991

May 10, 1992

June 10, 1992

June 10, 1992

Sept. 18, 1992
Fine sand:

Aug. 17, 1990

May 9, 1991

June 26, 1991

June 28, 1991

Aug. 12, 1991

May 12, 1992

June 9, 1992

June 9, 1992

Sept. 17, 1992 
Field experiment: Different fertilizers as $\mathrm{Zn}$ sources for barley

Experimental years: 1990, 1991 and 1992

Method: Randomized blocks

Plot size: $2.3 \mathrm{~m} \times 10 \mathrm{~m}$

Harvested area: $1.5 \mathrm{~m} \times 10 \mathrm{~m}$

Replicates: 4

Soils: Clay, mull and fine sand

Crop: Barley, cultivar 'Kymppi' (clay and fine sand soil), cultivar 'Kalle' (mull soil)

Application of $\mathrm{Zn}$ : A total of $5.4 \mathrm{~kg} \mathrm{ha}^{-1}$ during three years (4.8 $\mathrm{kg} \mathrm{ha}^{-1}$ in NPK 18-3-12; Control: no $\mathrm{Zn}$ applied)

Application of $N, P$ and $K: 108-110,19-20$ and $74-76 \mathrm{~kg} \mathrm{ha}^{-1}$, respectively, to clay and fine sand soil, 110,39 and 73-78 $\mathrm{kg} \mathrm{ha}^{-1}$, respectively, to mull soil

Herbicides: mixtures of mecoprope, dichlorprope and MCPA (Dipro, Hormoprop, Hormoneste); tribenurone-methyle (Express)

Fungicide: propiconazole (Tilt)

Insecticide (in 1992 only): dimethoate (Roxion), supermetrine (Ripcord)

Growth regulators: chlormequate chloride (CCC), mepiquate chloride, etephone (Terpal)

Application of $\mathrm{Zn}$ and NPK fertilizers in the 3-year field experiments with barley:

\begin{tabular}{lcc}
\hline Treatment & $\begin{array}{c}\mathrm{Zn} \\
\mathrm{kg} \mathrm{ha}^{-1}\end{array}$ & $\begin{array}{c}\text { NPK } \\
\text { fertilizer' }\end{array}$ \\
\hline 1. Control; no $\mathrm{Zn}$ application & 0 & 1 \\
2. $\mathrm{ZnSO}_{4} \cdot 7 \mathrm{H}_{2} \mathrm{O} 24 \mathrm{~kg} \mathrm{ha}^{-1}$ in the first spring & 5.4 & 1 \\
3. 'Sinkkilannos' $180 \mathrm{~kg} \mathrm{ha}^{-1}$ in the first spring & $3 \times 1.8$ & 1 \\
4. $\mathrm{Na}_{2} \mathrm{Zn}$-EDTA $12 \mathrm{~kg} \mathrm{ha}^{-1}$ sprayed onto the soil annually & $3 \times 1.6$ & 1 \\
5. $\mathrm{NPK} 18-3-12,610 \mathrm{~kg} \mathrm{ha}^{-1}$ annually & $3 \times 1.8$ & 2 \\
6. Coated NPK I annually & $3 \times 1.8$ & 1 \\
7. $\mathrm{Na}_{2} \mathrm{Zn}$-EDTA $12 \mathrm{~kg} \mathrm{ha}^{-1}$ sprayed annually onto the foliage & \\
\hline
\end{tabular}

In clay and fine sand soil:

$1=$ NPK 25-4-4 $440 \mathrm{~kg} \mathrm{ha}^{-1}, \mathrm{KCl} 110 \mathrm{~kg} \mathrm{ha}^{-1}$

$2=$ NPK 18-3-12 $610 \mathrm{~kg} \mathrm{ha}^{-1}$

3 = Coated NPK I $460 \mathrm{~kg} \mathrm{ha}^{-1}, \mathrm{KCl} 110 \mathrm{~kg} \mathrm{ha}^{-1}$

In mull soil:

$1=$ NPK 17-6-12 $650 \mathrm{~kg} \mathrm{ha}^{-1}$

2 = NPK 18-2-12 $610 \mathrm{~kg} \mathrm{ha}^{-1}$, Triple superphosphate $105 \mathrm{~kg} \mathrm{ha}^{-1}$

3 = Coated NPK I $460 \mathrm{~kg} \mathrm{ha}^{-1}$, Triple superphosphate $105 \mathrm{~kg} \mathrm{ha}^{-1}, \mathrm{KCl} 110 \mathrm{~kg} \mathrm{ha}^{-1}$

Dates of farming operations and length of the growing period:

Clay Mull Fine sand

1990:

Sowing

Foliar application of $\mathrm{Na}_{2} \mathrm{Zn}$-EDTA

Harvest

Growing period

1991:

Sowing

Foliar application of $\mathrm{Na}_{2} \mathrm{Zn}$-EDTA

Harvest

Growing period

1992:

Sowing

Foliar application of $\mathrm{Na}_{2} \mathrm{Zn}$-EDTA

Harvest

Growing period

\begin{tabular}{|c|c|c|}
\hline April 30 & May 7 & May 4 \\
\hline June 6 & June 6 & June 6 \\
\hline Aug. 16 & Aug. 20 & Aug. 16 \\
\hline $109 \mathrm{~d}$ & $105 \mathrm{~d}$ & $104 \mathrm{~d}$ \\
\hline May 13 & May 27 & May 15 \\
\hline June 28 & July 03 & June 28 \\
\hline Aug. 28 & Sept. 2 & Aug. 27 \\
\hline $107 \mathrm{~d}$ & $98 \mathrm{~d}$ & $104 \mathrm{~d}$ \\
\hline
\end{tabular}

May 21

July 7

Aug. 17

$88 \mathrm{~d}$

May 27

June 30

May 21

July 1

Aug. 26

Aug. 31

$96 \mathrm{~d}$

$97 \mathrm{~d}$ 
Field experiment: Zinc concentration of barley as affected by different $\mathrm{Zn}$ rates

Experimental years: 1991 and 1992

Method: Randomized blocks

Plot size: $2.3 \mathrm{~m} \times 5 \mathrm{~m}$

Harvested area: $0.5 \mathrm{~m}^{2}$ (two subsamples of $0.25 \mathrm{~m}^{2}$ ) four times during the growing period

Replicates: 4

Soils: Clay and fine sand

Crop: Barley, cultivar 'Kymppi' (270 kg ha-1)

Application of $\mathrm{Zn}$ : 15 or $30 \mathrm{~kg} \mathrm{Zn} \mathrm{ha-1}$ as $\mathrm{ZnSO}_{4} \cdot 7 \mathrm{H}_{2} \mathrm{O}$ in spring of 1991, (Control: no $\mathrm{Zn}$ applied)

Application of $N, P$ and $K: 110,22$ and $44 \mathrm{~kg} \mathrm{ha}^{-1}$, respectively (Fertilizer: NPK 20-4-8 $550 \mathrm{~kg} \mathrm{ha}^{-1}$ )

Herbicide: tribenurone-methyle (Express)

Insecticide (in 1992 only): dimethoate (Roxion)

Growth regulator: chlormequate chloride (CCC)

Dates of sowing, sampling and harvesting and length of the growing period:

\begin{tabular}{|c|c|c|c|c|}
\hline & \multicolumn{2}{|c|}{1991} & \multicolumn{2}{|c|}{1992} \\
\hline & Clay & Fine sand & Clay & Fine sand \\
\hline Sowing & May 17 & May 16 & May 21 & May 20 \\
\hline Sampling at Feekes 2 & June 24 & June 24 & June 18 & June 15 \\
\hline Sampling at Feekes 5 & July 8 & July 5 & July 3 & June 29 \\
\hline Sampling at Feekes 10.5 & July 26 & July 24 & July 21 & June 20 \\
\hline Harvest & - & Aug. 28 & Aug. 20 & Aug. 24 \\
\hline Growing period & & $104 \mathrm{~d}$ & $91 \mathrm{~d}$ & $96 \mathrm{~d}$ \\
\hline
\end{tabular}

